PNL-9914 Rev. 2

Ur-721

\title{
The Sort on Radioactive Waste Type Model: A Method to Sort Single-Shell Tanks into Characteristic Groups
}
J. G. Hill
G. S. Anderson
B. C. Simpson

March 1995

Prepared for the U.S. Department of Energy under Contract DE-AC06-76RLO 1830

Pacific Northwest Laboratory Operated for the U.S. Department of Energy by Battelle Memorial Institute 


\title{
DISCLAIMER
}

This report was prepared as an account of work sponsored by an agency of the United States Government. Neither the United States Government nor any agency thereof, nor Battelle Memorial Institute, nor any of their employees, makes any warranty, expressed or implied, or assumes any legal liability or responsibility for the accuracy, completeness, or usefulness of any information, apparatus, product, or process disclosed, or represents that its use would not infringe privately owned rights. Reference herein to any specific commercial product, process, or service by trade name, trademark, manufactuser, or otherwise does not necessarily constitute or imply its endorsement, recommendation, or favoring by the United States Government or any agency thereof, or Battelle Memorial Institute. The views and opinions of authors expressed herein do not necessarily state or reflect those of the United States Government or any agency thereof.

\author{
PACIFIC NORTHWEST LABORATORY \\ operated by \\ BATTELLE MEMORIAL INSTITUTE \\ for the \\ UNITED STATES DEPARTMENT OF ENERGY \\ under Contract DE-AC06-76RLO 1830
}

Printed in the United States of America

Available to DOE and DOE contractors from the

Office of Scientific and Technical Information, P.O. Box 62, Oak Ridge, TN 37831; prices available from (615) 576-8401. FTS 626-8401.

Available to the public from the National Technical Information Service,
U.S. Department of Commerce, 5285 Port Royal Rd., Springfield, VA 22161. 
PNL-9814 Rev. 2

UC-721

\section{The Sort on Radioactive Waste Type Model: A Method to Sort Single-Shell Tanks into Characteristic Groups}
J. G. Hill
G. S. Anderson
B. C. Simpson ${ }^{(a)}$

March 1995

Prepared for

the U.S. Department of Energy

under Contract DE-AC06-76RLO 1830

Pacific Northwest Laboratory

Richland, Washington 99352

(a) Westinghouse Hanford Company. 


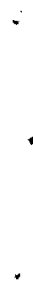




\section{Summary}

The Sort on Radioactive Waste Type (SORWT) model presents a method to categorize Hanford Site single-shell tanks (SSTs) into groups expected to exhibit similar chemical and physical characteristics based on their major waste types and processing histories. This report contains the assumptions and methodologies used to develop the SORWT model and presents the grouping results, along with a detailed statistical verification study that integrated analysis of variance (ANOVA) and core sample analysis data collected since 1989 for five SORWT groups. Nominal compositions and inventories are given for these five SORWT groups.

The SORWT model has identified 24 different waste-type groups encompassing 133 of the 149 SSTs and $93 \%$ of the total waste volume in SSTs. The first 14 groups (those that contain four tanks per group or more) represent 109 tanks and over $83 \%$ of the total waste volume. Sixteen SSTs and associated wastes could not be grouped according to the established criteria and were placed in an ungrouped category.

The verification study showed that the SST groups predicted by the SORWT model are highly statistically significant and that grouping the tanks reduces the variability in the concentrations for all analytes examined. A high degree of agreement was found between the observed characteristics determined by laboratory analyses for the five SORWT groups and the expected characteristics based solely on the waste type. These similarities provide further evidence that the SORWT grouping methodology is accurately and effectively predicting real distinctions between groups of tanks.

The SORWT model organizes a large amount of information and presents options, depending on the criteria applied, for selecting the most desirable SSTs for sampling and for determining core sampling schedules. A list of tanks recommended for sampling based on the SORWT model results is included in this report. The list takes advantage of the SORWT model groups to establish a substantial amount of characterization information from a relatively small number of core and auger samples.

Thirty-two core samples from 16 tanks and 18 auger samples from six tanks are recommended. If this new sampling and analysis information is combined with the existing data, nominal compositions of 104 tanks (70\%) could be established, which would represent approximately $79 \%$ of the total waste volume, $63 \%$ of the total sludge volume, and $88 \%$ of the salt cake volume. The information gained from this effort could greatly contribute to the base of knowledge concerning the characteristics of tank waste. 


\section{Contents}

Summary $\ldots \ldots \ldots \ldots \ldots \ldots \ldots \ldots \ldots \ldots \ldots \ldots \ldots \ldots \ldots$ iii

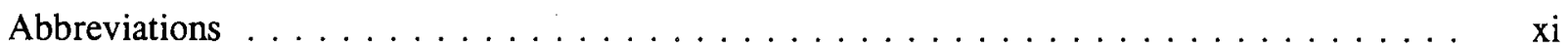

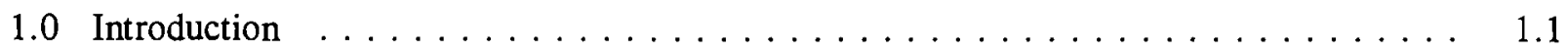

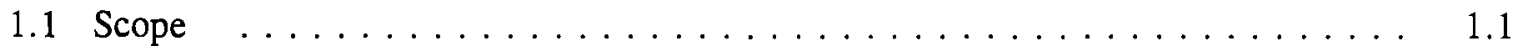

1.2 History of the SORWT Model Development $\ldots \ldots \ldots \ldots \ldots \ldots \ldots$

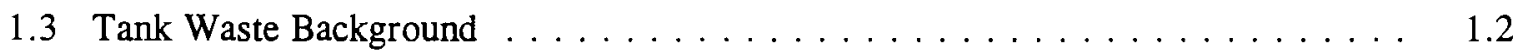

2.0 Overview of the SORWT Model $\ldots \ldots \ldots \ldots \ldots \ldots \ldots \ldots \ldots \ldots \ldots$

2.1 Data Sources for the SORWT Model $\ldots \ldots \ldots \ldots \ldots \ldots \ldots \ldots \ldots$

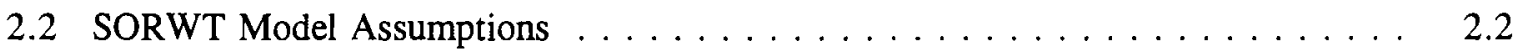

2.3 SORWT Model Input Data Sheets $\ldots \ldots \ldots \ldots \ldots \ldots \ldots \ldots \ldots$

3.0 Presentation of SORWT Model Results $\ldots \ldots \ldots \ldots \ldots \ldots \ldots \ldots$

3.1 SORWT Model Report Format $\ldots \ldots \ldots \ldots \ldots \ldots \ldots \ldots \ldots \ldots$

3.2 Summary of SORWT Model Waste-Type Groups $\ldots \ldots \ldots \ldots \ldots \ldots$

3.3 Description of SORWT Waste-Type Groups $\ldots \ldots \ldots \ldots \ldots \ldots \ldots$

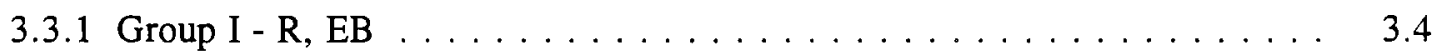

3.3 .2 Group II $-\mathrm{EB}, 1 \mathrm{C} \ldots \ldots \ldots \ldots \ldots \ldots \ldots$

3.3 .3 Group III - TBP-F, EB-ITS $\ldots \ldots \ldots \ldots \ldots \ldots \ldots \ldots \ldots$

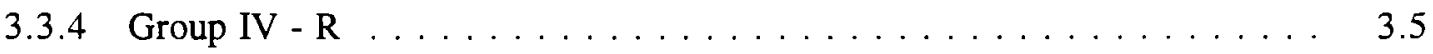

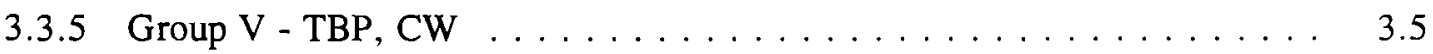

3.3 .6 Group VI $-\mathrm{EB}, \mathrm{CW} \ldots \ldots \ldots \ldots \ldots \ldots \ldots \ldots$

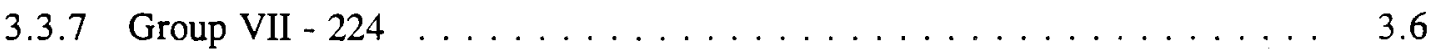

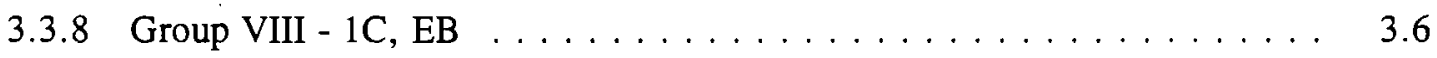


3.3.9 Group IX - EB, R $\ldots \ldots \ldots \ldots \ldots \ldots \ldots \ldots \ldots \ldots \ldots$

3.3.10 Group $\mathrm{X}-1 \mathrm{C}, \mathrm{CW} \ldots \ldots \ldots \ldots \ldots \ldots \ldots \ldots \ldots \ldots \ldots \ldots$

3.3.11 Group XI - DSSF, NCPLX $\ldots \ldots \ldots \ldots \ldots \ldots \ldots \ldots \ldots \ldots$

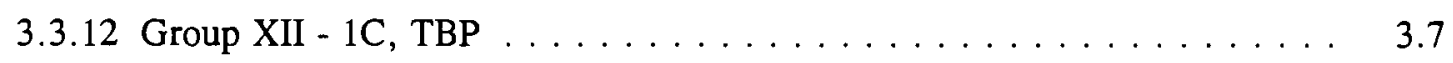

3.3.13 Group XIII - TBP-F, 1 C $\ldots \ldots \ldots \ldots \ldots \ldots \ldots \ldots \ldots \ldots \ldots \ldots$

3.3.14 Group XIV - HS $\ldots \ldots \ldots \ldots \ldots \ldots \ldots \ldots \ldots \ldots \ldots \ldots$

3.3.15 Group XV - 2C, $224 \ldots \ldots \ldots \ldots \ldots \ldots \ldots \ldots \ldots \ldots \ldots \ldots \ldots$

3.3.16 Group XVI - 2C, $5-6 \ldots \ldots \ldots \ldots \ldots \ldots \ldots \ldots \ldots \ldots \ldots \ldots \ldots$

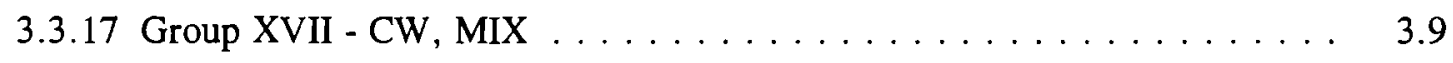

3.3.18 Group XVIII - CW $\ldots \ldots \ldots \ldots \ldots \ldots \ldots \ldots \ldots \ldots \ldots \ldots$

3.3.19 Group XIX - TBP, EB-ITS $\ldots \ldots \ldots \ldots \ldots \ldots \ldots \ldots \ldots \ldots$

3.3 .20 Group XX - SRS, SR-WASH $\ldots \ldots \ldots \ldots \ldots \ldots \ldots \ldots \ldots \ldots$

3.3.21 Group XXI - TBP, EB $\ldots \ldots \ldots \ldots \ldots \ldots \ldots \ldots \ldots \ldots$

3.3.22 Group XXII - TBP, 1 C-F $\ldots \ldots \ldots \ldots \ldots \ldots \ldots \ldots \ldots \ldots \ldots \ldots \ldots$

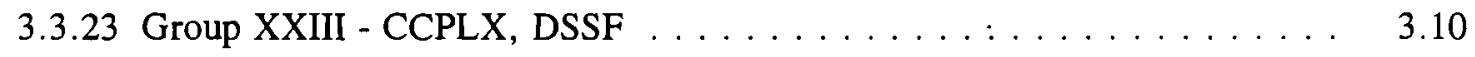

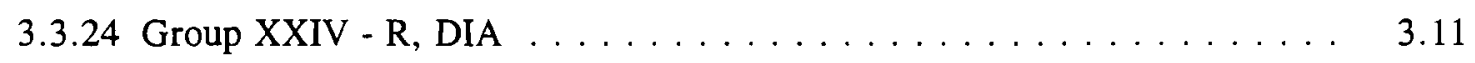

3.3.25 Group XXV - Solitary Tanks (Ungrouped) $\ldots \ldots \ldots \ldots \ldots \ldots \ldots .11$

4.0 Statistical Verification of the SORWT Model $\ldots \ldots \ldots \ldots \ldots \ldots \ldots \ldots \ldots .1$

4.1 Approach to Verification of the SORWT Model $\ldots \ldots \ldots \ldots \ldots \ldots \ldots .1$

4.1.1 Analytical Data Sources for the Verification Study $\ldots \ldots \ldots \ldots \ldots .2$

4.1.2 Graphical Description of the Verification Data Set $\ldots \ldots \ldots \ldots .4 .7$

4.1.3 Characteristics of Waste Types Included in SORWT Verification Study . . $\quad 4.8$ 
4.2 Analysis of Variance Results $\ldots \ldots \ldots \ldots \ldots \ldots \ldots \ldots \ldots \ldots \ldots \ldots \ldots$

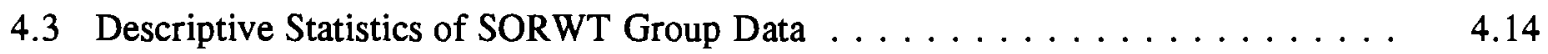

4.4 Pairwise Comparisons . . . . . . . . . . . . . . . . 4.15

4.4.1 Expected Compositional Differences Between SORWT Groups . . . . . . 4.15

4.4.2 Comparison of Observed and Expected Difference Between Different

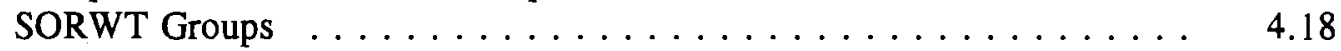

5.0 Nominal Compositions and Inventory of Five SORWT Groups $\ldots \ldots \ldots . \ldots$

5.1 Nominal Composition of Group VII $\ldots \ldots \ldots \ldots \ldots \ldots \ldots$

5.2 Nominal Composition of Group IV $\ldots \ldots \ldots \ldots \ldots \ldots \ldots$

5.3 Nominal Composition of Group XII $\ldots \ldots \ldots \ldots \ldots \ldots \ldots$

5.4 Nominal Composition of Group XV $\ldots \ldots \ldots \ldots \ldots \ldots \ldots$

5.5 Nominal Composition of Group XVI $\ldots \ldots \ldots \ldots \ldots \ldots$

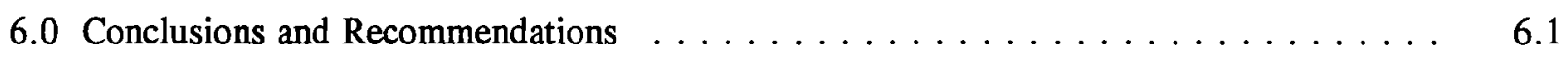

6.1 Recommended Tank Waste Sampling $\ldots \ldots \ldots \ldots \ldots \ldots \ldots \ldots \ldots$

6.2 Recommended Suite of Analyses $\ldots \ldots \ldots \ldots \ldots \ldots \ldots \ldots$

7.0 References $\ldots \ldots \ldots \ldots \ldots \ldots \ldots \ldots \ldots \ldots \ldots \ldots \ldots \ldots \ldots$

Appendix A - Sort on Radioactive Waste Type Model Results $\ldots \ldots \ldots \ldots \ldots$. . . . . .

Appendix B - Waste Types in Hanford Site Single-Shell Tanks $\ldots \ldots \ldots \ldots$. . . . . B.1

Appendix C - Core Sample Analytical Data Tables Used in the SORWT Model

Verification Study . . . . . . . . . . . . . . . . . C. 1

Appendix D - Box Plots of Core Sample Analytical Data Used in the SORWT Model

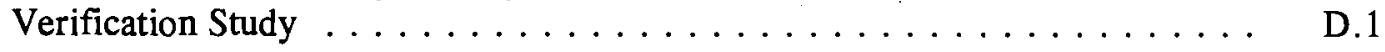

Appendix E - ANOVA Results of Core Sample Analytical Data Used in the SORWT Model

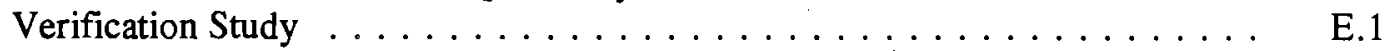

Appendix F - Descriptive Statistics of Core Sample Analytical Data Used in the SORWT Model

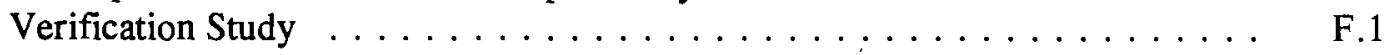




\section{Figure}

4.1 Box Plot of Sodium Concentration by SORWT Group $\ldots \ldots \ldots \ldots \ldots$

\section{Tables}

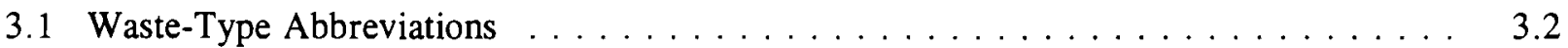

3.2 Summary of SORWT Model Results $\ldots \ldots \ldots \ldots \ldots \ldots \ldots \ldots$

4.1 SORWT Groups and Tanks Included in Verification Study $\ldots \ldots \ldots \ldots \ldots .2$

4.2 Core Sample Analytical Data Sources $\ldots \ldots \ldots \ldots \ldots \ldots \ldots \ldots \ldots$

4.3 Analytes, Sample Preparation, and Analytical Method Used in the SORWT

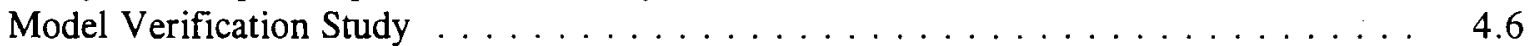

4.4 Summary of ANOVA for SORWT Verification Study $\ldots \ldots \ldots \ldots \ldots \ldots \ldots$

4.5 Number of Analytes Showing Significant Difference Between Groups $\ldots \ldots \ldots$. . . . 4.13

4.6 Analytes Showing Significant Concentration Difference Between Groups $\ldots \ldots$. . . . 4.13

4.7 Nominal Compositions of Five SORWT Groups $\ldots \ldots \ldots \ldots \ldots \ldots \ldots$

4.8 Concentration Categories for Expected Characteristics $\ldots \ldots \ldots \ldots \ldots \ldots \ldots$

4.9 Pairwise Comparison of Expected Characteristics $\ldots \ldots \ldots \ldots \ldots \ldots$

4.10 Pairwise Comparison of Observed Characteristics $\ldots \ldots \ldots \ldots \ldots$

4.11 Comparison of Observed to Expected Characteristics $\ldots \ldots \ldots \ldots \ldots \ldots \ldots$

5.1 Nominal Composition and Inventory of Group VII $\ldots \ldots \ldots \ldots \ldots \ldots \ldots$

5.2 Nominal Composition and Inventory of Group IV $\ldots \ldots \ldots \ldots \ldots \ldots$

5.3 Nominal Composition and Inventory of Group XII $\ldots \ldots \ldots \ldots \ldots \ldots$

5.4 Nominal Composition and Inventory of Group XV $\ldots \ldots \ldots \ldots$

5.5 Nominal Composition and Inventory of Group XVI $\ldots \ldots \ldots \ldots \ldots$ 
6.1 List of Recommended Core Samples $\ldots \ldots \ldots \ldots \ldots \ldots \ldots \ldots \ldots \ldots$

6.2 List of Recommended Auger Samples $\ldots \ldots \ldots \ldots \ldots \ldots \ldots \ldots \ldots$

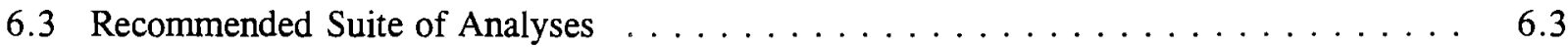




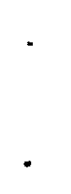

- 


\section{Abbreviations}

$1 \mathrm{C}$

224

2C

5-6

AES

ANN

ANOVA

$\mathrm{BiPO}_{4}$

B

BL

CV

CCPLX

$\mathrm{CW}$

DIA

DOE

DSSF

DSC/TGA

DW

EB

EVAP

F

GEA

HDRL

HS

ICP

ITS

IX

MIX

MW

NCPLX

NWL

$P$

PNL

PUREX

R first decontamination cycle waste

lanthanum fluoride decontamination waste

second decontamination cycle waste

high-level B Plant waste from the bottom of Section 5

atomic emission spectroscopy

aluminum nitrate nono hydrate

analysis of variance

bismuth phosphate

high-level B Plant waste from waste fractionization process

B Plant low-level waste

coefficient of variance

complex concentrate

cladding waste

diatomaceous earth

U.S. Department of Energy

double-shell slurry feed

differential scanning calorimetry/thermal gravimetric analysis

decontamination waste

evaporator bottoms

post-1976 evaporator feed

ferrocyanide-scavenged waste

gamma energy analysis

Hanford defense residual liquor

hot semiworks waste

inductively coupled plasma

in-tank solidification

ion exchange waste

mixture of several miscellaneous wastes

metal waste

noncomplexed waste

non-watch list

neutralized acid waste

Pacific Northwest Laboratory

plutonium-uranium extraction

high-level REDOX waste 


$\begin{array}{ll}\text { REDOX } & \text { reduction/oxidation } \\ \text { RESD } & \text { residual liquor } \\ \text { SEIS } & \text { Supplemental Environmental Impact Statement } \\ \text { SORWT } & \text { Sort on Radioactive Waste Type } \\ \text { SRS } & \text { strontium leached sludge } \\ \text { SR-WASH } & \text { particulates from Sr wash of PUREX wastes in the AR vault } \\ \text { SST } & \text { single-shell tank } \\ \text { TBP } & \text { tributyl phosphate } \\ \text { TL } & \text { terminal liquor } \\ \text { TOC } & \text { total organic carbon } \\ \text { TRAC } & \text { Track Radioactive Components } \\ \text { TWRS } & \text { Tank Waste Remediation System } \\ \text { WHC } & \text { Westinghouse Hanford Company }\end{array}$




\subsection{Introduction}

This report discusses the Sort on Radioactive Waste Type (SORWT) model, which was developed to qualitatively categorize the Hanford single-shell tanks (SSTs) into characteristic groups. The results provided by this grouping model will contribute to a better understanding of the contents of the tanks and help predict the nominal physical and chemical characteristics of an entire group of tanks based on limited sampling and analysis. This model also provides a basis for guiding and prioritizing sampling and analytical efforts.

\subsection{Scope}

The SORWT model provides a qualitative grouping methodology for SSTs according to their significant waste types and processing history, and a best engineering judgment based on the available information. Tanks that received similar wastes and underwent similar process histories should have a high degree of similarity in chemical content and physical characteristics. This premise forms the basis of the grouping scheme. A limited number of tanks can provide sufficient information on which to base final processing and disposal decisions, if the tanks selected provide a representative sample of the waste types and conditions in the SSTs.

This report contains an overview of the model, the waste-type groups predicted, and the characteristics of the waste types included in a verification study, as well as the verification study itself. The verification study quantitatively supports the model using a detailed analysis of variance (ANOVA) of the relevant and available characterization data obtained from recent (post-1989) core sampling and analysis activities. The results from the ANOVA study demonstrated the SST groups predicted by the model to be highly statistically significant. In addition, the SORWT model has been used to predict the nominal waste characteristics of entire waste-type groups that have some recent characterization data available.

Several appendices have been included: Appendix A contains the detailed SORWT results; Appendix B lists the waste types determined for Hanford SSTs; Appendices C through F provide the core sample analytical data tables, box plots, ANOVA results, and descriptive statistics resulting from the verification study.

\subsection{History of the SORWT Model Development}

The SORWT model was first proposed by Westinghouse Hanford Company (WHC) in 1991 as a means to guide the waste tank characterization effort at Hanford and to help accelerate the acquisition of characterization data on the SST wastes in support of a Supplemental Environmental Impact Statement (SEIS). The model results provided a key to the selection of tanks to be core sampled in FY 1992, as discussed in the Waste Characterization Plan for the Hanford Site Single-Shell Tanks (Hill et al. 1991). 
Eighteen core samples were collected and analyzed from seven SSTs in accordance with this plan. One of the selection criteria for these tanks was to provide data from pairs of tanks in the same group as well as from different SORWT groups for comparison with the predictions made by the SORWT model. These data would then be used to conduct a statistical verification study to assess the effectiveness of the grouping methodology. A draft document was prepared in August 1991 presenting the methodology, results, and statistical discussion of the SORWT model. However, because of shifts in U.S. Department of Energy (DOE) programmatic directions, formal documentation was postponed.

In the spring of 1994, the methodology and results portion of the original model was published for the Tank Waste Remediation System (TWRS), which is managed for DOE by WHC. The report, The Sort on Radioactive Waste Type Model: A Method to Sort Single-Shell Tanks into Characteristic Groups (Hill and Simpson 1994a), was revised in August 1994 (Hill and Simpson 1994b) to include additional descriptive information on waste types present in SSTs.

During the last quarter of FY 1994, further studies were conducted for the TWRS Tank Waste Treatment Science Task, which is being led by Pacific Northwest Laboratory (PNL) ${ }^{(a)}$. These studies were aimed at verifying the results of the SORWT model to provide a better technical basis for using the model results in overall tank waste pretreatment strategies. The laboratory data from the cores taken in 1992 were available, and the detailed statistical verification study using analysis of variance was conducted. In addition, the tank waste volumes used in the model were updated using the March 1994 Tank Farm Surveillance and Waste Status Summary Report (Hanlon 1994). The initial report used waste volume data from the July 1990 report (Hanlon 1990).

\subsection{Tank Waste Background}

Between 1943 and 1964, 149 SSTs were built for the storage of liquid and solid radioactive wastes at the Hanford Site. These tasks, which are located in 12 tank farms of four to 18 tanks each in the 200 East and 200 West Areas, have been removed from active service and have not received any additional wastes since November 1980 . Before the tanks were removed from active service, various waste volume reduction programs were undertaken to minimize the amount of occupied tank volume. These programs involved inter-tank transfers, evaporation, and chemical alterations of the waste. These actions, combined with the ongoing chemical and radiolytic in-tank processes, have changed the character of the waste in the SSTs over time, and now the actual composition of the wastes in the SSTs needs to be determined to make further technical and regulatory disposal decisions.

The wastes in the SSTs originated from a limited number of chemical processes and waste solidification schemes. The primary chemical processes at Hanford were the bismuth phosphate $\left(\mathrm{BiPO}_{4}\right)$ plutonium recovery and purification process, the uranium recovery tributyl phosphate (TBP) process, the REDOX (reduction/oxidation with solvent extraction) process, and the PUREX (plutonium-uranium extraction) processes. Each of these major processes also had several affiliated operations, such as the

(a) Operated for the U.S. Department of Energy by Battelle Memorial Institute under Contract DE-AC06-76RLO 1830. 
first and second decontamination cycle processes, the lanthanum fluoride process, fuel element decladding, ferrocyanide scavenging, fission product recovery, and several minor associated processes. The waste solidification schemes generally involved processes that treated waste outside of the tanks, such as the 242-B and 242-T Concentrators and the 242-A and 242-S Evaporator/Crystallizers. These units took the dilute waste from the tank, evaporated the excess water, and returned the concentrated waste to the tank. However, there were in-tank solidification (ITS) processes that removed the excess water directly from tank wastes using a hot-air sparge (ITS-1) or from a series of tanks using an in-tank electric heater (ITS-2). Excess water was also removed simply from self concentration as a result of dissipating excess radioactive decay heat.

There have been several previous attempts to group the tanks; however, there is no currently accepted method. The previous methods were unacceptable because of their reliance on the TRAC (Track Radioactive Components) model as a basis (Jungfleisch 1984); the TRAC model can be shown to be internally inconsistent and inconsistent with other sources of reliable information regarding waste in the tanks (Adams et al. 1986; Morgan et al. 1988). The proposed method does not use the TRAC document's quantitative estimates regarding waste composition in the tanks for grouping. The grouping method is instead a qualitative judgment about the tanks that are similar in content and character based on the transaction information in A History of the 200 Area Tank Farms (Anderson 1990) and several generic assumptions about the physical and chemical makeup of the wastes in the tanks. This grouping method then uses a database to sort the tanks on the basis of similarity in overall waste types and processing history. 


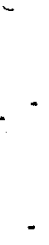




\subsection{Overview of the SORWT Model}

The SORWT model categorizes tanks into groups expected to have similar physical characteristics and chemical compositions. Because of the complex physical and chemical history of the SSTs, especially when several different waste types were mixed or processed together, the model does not attempt to predict the precise composition of a waste tank. Instead, the sorting method concentrates on the different types of waste introduced into each SST, each waste's distinct contribution to the known properties, the individual significance of each waste type, and the process history of each of the tanks. Although the actual chemical reactions and phase equilibria may be unknown when two waste types are combined in an SST, it can be assumed that similar reactions and equilibria occur in other SSTs when ! the same two waste types are mixed.

The fundamental premise of the SORWT model is that there are identifiable patterns with regard to the production and waste management practices that were conducted in the tank farms. Thus, tanks that received the same waste types in the same approximate proportion and had a similar processing history will be more similar to one another than SSTs that received several different waste types in varying amounts and had a relatively unique process history. In addition, largely supernatant waste types are presumed not to have as significant an effect on the character of the waste in the tank as solidforming waste types. Therefore, if the primary and secondary solid-forming waste types can be identified for each SST, the tanks can be grouped based on these criteria. Thus, information about the character of the waste in the rest of the members in the group can be deduced from the information obtained by the analysis of the samples from the representative tank, or from a selected number of representative tanks.

\subsection{Data Sources for the SORWT Model}

The principal source of SST waste-type information used by this model has been $A$ History of the 200 Area Tank Farms (Anderson 1990). This document contains much of the available processing history for each of the 149 SSTs from 1944 until 1980. However, the historical records used to generate Anderson (1990) were often inaccurate and/or incomplete. The methods utilized to measure accumulated solid and liquid volumes during the early history of the Hanford Site produced inconsistent inventories. Indeed, solids inventories were not routinely taken until the mid-1950s. Often, tank transfer information was missing. Despite these inconsistencies, Anderson (1990) is still one of the best sources of SST historical information, and it is believed a qualitative assessment of the principal solids-forming waste types contained in each SST can be accurately determined from this information.

Often in the course of the process histories of the SSTs, the wastes in the tanks were given new names to reflect their suitability for further processing or the presence of complexing agents. Occasionally, the same waste types were assigned different names at different times. For example, terminal liquor (TL), Hanford defense residual liquor (HDRL), and residual liquor (RESD) all identify the same waste. Whenever possible these broad, nonspecific waste category names were avoided, and 
the actual waste type from one of the process operations was used for the sorting criteria. In addition, the suffix $F$ was added to some of the waste types to identify ferrocyanide-scavenged waste, and ITS was added to designate tanks that were in the In-Tank Solidification program.

The volumes of waste contained in each SST were obtained from the Tank Farm Surveillance and Waste Status Summary Report (Hanlon 1994). These values include, on a per-tank-basis, total waste volume, volume of salt cake, volume of sludge, and volume of supernatant liquid. It can be assumed that these values are more accurate than those final values found in Anderson (1990) because they were obtained more recently; however, it is understood that these values have deficiencies because of the limited access to the tanks.

\subsection{SORWT Model Assumptions}

The underlying assumptions utilized by the SORWT model are as follows:

- The information contained within Anderson (1990) is sufficient to qualitatively identify and rank relative to one another the waste types that contributed to the accumulated solids in each SST.

- The Hanlon (1994) inventory values and phase partition information regarding sludge and salt cake amounts are reasonably accurate.

- The SST process history, primary solids-forming, and secondary solids-forming waste types were responsible for the majority of the physical characteristics and chemical compositions of the waste remaining in each SST.

- Supernatant wastes that were not allowed to remain in a tank for a long period of time and were later pumped out of the SST had less influence on the physical and chemical character of the waste than did the insoluble solid waste types.

- SSTs were often sluiced at some time during their processing history. Sluicing involves removing solids from waste tanks using high-pressure water jets. Waste types present in the tank prior to the most recent sluicing were not considered relevant by this model.

- Broad-ranging, less descriptive waste types, such as NCPLX (noncomplexed waste), CCPLX (complex concentrate), EVAP (post-1976 evaporator feed), and/or DSSF (double-shell slurry feed), were avoided whenever possible. The previous nomenclature for those waste types was preferred, if available; however, a broad category identifying the tank waste as either noncomplexed, complexed, or ferrocyanide-scavenged waste has, in some instances, been included in the SORWT model to aid in evaluating the results of the model. 


\subsection{SORWT Model Input Data Sheets}

SORWT model input sheets were generated for each tank by thorough evaluation of the processing histories found in Anderson (1990) and Hanlon (1994). The waste type judged to be the most significant contributor to the solids volume in any specific SST was identified as the Primary Waste Type. This evaluation was made on the basis of waste volume introduced into each tank and the solids accumulation during the regime of that particular waste. The second most significant solids-forming waste type was identified as the Secondary Waste Type. When appropriate, a Tertiary and an Other Waste Type were also identified.

Because waste prior to sluicing has been disregarded by the SORWT model, the date of the most recent sluicing event for each tank has been included on the input sheets. The volume of waste remaining in the tank after sluicing has also been included to aid in the sorting and analysis. The data were obtained from Anderson (1990).

The waste volumes remaining in each SST, segregated into salt cake, sludge, supernatant liquid, and total, were collected from Hanlon (1994). Although the waste volume information was not used as a sorting criterion, it can be used as an indication of grouping feasibility. A realistic group, as predicted by the SORWT model, exhibiting similar physical and chemical characteristics, should not include tanks that have widely varying ratios between sludge and salt cake. If the majority of tanks in a group contain all sludge and one tank contains all salt cake, the membership of that tank in the group would be in question. The tank waste volume information also provides valuable insight into those tanks in a group that have greater significance due to their higher volume. 


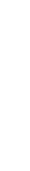




\subsection{Presentation of SORWT Model Results}

The SORWT model results were presented using a database software package to generate the report. Tanks possessing the same primary and secondary waste types were grouped together. Wastetype abbreviations are summarized in Table 3.1. From the database package, the report output was imported into a word processor for additional editing. The different groups were listed in descending order of importance with the most significant group first. Following each group was a subtotal providing the number of tanks and the volume of salt cake, sludge, and total waste represented by that particular waste group as collected from Hanlon (1994).

\subsection{SORWT Model Report Format}

A full printout of the SORWT model report is presented in Appendix A. The first column of the SORWT model report contains the group I.D. in Roman numerals. The lower the number, the more significant the group in terms of number of tanks and total waste volume. Column 2 contains the tank names of the individual tanks that make up each group. Columns 3 and 4 report the primary and secondary waste types, respectively. These are the waste types believed to have contributed most significantly to the solids volume in that particular tank relative to other waste types introduced into that same tank and are the criteria for tank grouping. Within any given group, the primary and secondary waste types will always be identical. Columns 5 and 6 , respectively, contain the tertiary and other waste types. While the tertiary and other waste types are not actually used as grouping criteria, they are provided for further assistance in interpreting the results. Column 7 presents the safety watch list status of each tank. The codes used in this column are F, O, H, G, and N representing ferrocyanide, organic, high-heat, gas-generating, and non-public law tanks, respectively. The remaining columns list the volumes of waste in the corresponding phases and the total waste volume of each tank. The total waste volume does not include the interstitial liquid volume.

The second portion of Appendix A lists the volume percent of each phase and the percentage of the overall volume contained in each tank. In both the volume and the volume percentage portions of the appendix, the results have been subtotaled for each SORWT group.

\subsection{Summary of SORWT Model Waste-Type Groups}

The SORWT model has predicted the existence of 24 waste-type groups ranging from a high of 22 tanks per group to a low of two tanks per group. These 24 waste-type groups encompass 133 tanks and $93 \%$ of the total waste volume. An additional group contains the 16 solitary SSTs that did not fall into any waste-type groups. Table 3.2 presents a summary of the SST waste-type groups predicted by the SORWT model. 
Table 3.1. Waste-Type Abbreviations

\begin{tabular}{|c|c|}
\hline Abbreviation & Definition \\
\hline $5-6$ & High-level B Plant waste from bottom of Section 5 \\
\hline 224 & Lanthanum fluoride decontamination waste \\
\hline $1 \mathrm{C}$ & First decontamination cycle waste \\
\hline $2 \mathrm{C}$ & Second decontamination cycle waste \\
\hline B & $\begin{array}{l}\text { High-level waste from waste fractionization process at } \\
\text { B Plant }\end{array}$ \\
\hline $\mathrm{BL}$ & B Plant low-level waste \\
\hline CCPLX & Complex concentrate \\
\hline $\mathrm{CW}$ & Cladding waste \\
\hline DIA & Diatomaceous earth \\
\hline DSSF & Double-shell slurry feed \\
\hline DW & Decontamination waste \\
\hline EB & Evaporator bottoms \\
\hline EVAP & Evaporator feed (post-1976) \\
\hline $\mathrm{F}$ & Ferrocyanide-scavenged waste \\
\hline HS & Hot semiworks waste \\
\hline ITS & In-tank solidification \\
\hline IX & Ion exchange waste \\
\hline MIX & Mixture of several miscellaneous wastes \\
\hline MW & Metal waste \\
\hline NCPLX & Noncomplexed waste \\
\hline $\mathbf{P}$ & High-activity, neutralized acid waste \\
\hline PUREX & Plutonium-uranium extraction \\
\hline $\mathbf{R}$ & High-level REDOX waste \\
\hline SRS & Strontium leached sludge \\
\hline SR-WASH & Particulates from Sr wash of PUREX wastes in the AR vault \\
\hline TBP & Tributyl phosphate waste \\
\hline
\end{tabular}


Table 3.2. Summary of SORWT Model Results

\begin{tabular}{|c|c|c|c|c|c|c|c|c|}
\hline $\begin{array}{l}\text { Group } \\
\text { Number }\end{array}$ & $\begin{array}{r}P \mathrm{PI} \\
\text { and } S \\
\text { Waste- } \mathrm{T}\end{array}$ & $\begin{array}{l}\text { nary } \\
\text { condary } \\
\text { pe Groups }\end{array}$ & $\begin{array}{l}\text { Number } \\
\text { of Tanks } \\
\text { in Group }\end{array}$ & $\begin{array}{l}\text { \% of Total } \\
\text { Salt Cake } \\
\text { Volume }\end{array}$ & $\begin{array}{l}\% \text { of Total } \\
\text { Sludge } \\
\text { Volume }\end{array}$ & $\begin{array}{l}\text { \% of Total } \\
\text { Supernatant } \\
\text { Volume }\end{array}$ & $\begin{array}{c}\% \text { of Total } \\
\text { Interstitial } \\
\text { Liquid Volume }\end{array}$ & $\begin{array}{c}\% \text { of Total } \\
\text { Waste } \\
\text { Volume }\end{array}$ \\
\hline I & $\bar{R}$ & $\overline{E B}$ & 22 & $37 \%$ & $12 \%$ & $21 \%$ & $42 \%$ & $28 \%$ \\
\hline II & EB & $1 \mathrm{C}$ & 10 & $20 \%$ & $0 \%$ & $0 \%$ & $3 \%$ & $13 \%$ \\
\hline III & TBP-F & EB-ITS & 10 & $14 \%$ & $5 \%$ & $0 \%$ & $11 \%$ & $11 \%$ \\
\hline IV & $\mathrm{R}$ & & 10 & $0 \%$ & $10 \%$ & $1 \%$ & $1 \%$ & $3 \%$ \\
\hline V & TBP & $\mathrm{CW}$ & 9 & $0 \%$ & $5 \%$ & $5 \%$ & $1 \%$ & $2 \%$ \\
\hline VI & EB & $\mathrm{CW}$ & 8 & $8 \%$ & $3 \%$ & $20 \%$ & $11 \%$ & $6 \%$ \\
\hline VII & 224 & & 8 & $0 \%$ & $2 \%$ & $1 \%$ & $0 \%$ & $1 \%$ \\
\hline VIII & $1 \mathrm{C}$ & EB & 6 & $1 \%$ & $6 \%$ & $0 \%$ & $1 \%$ & $3 \%$ \\
\hline IX & EB & $\mathbf{R}$ & 5 & $8 \%$ & $1 \%$ & $8 \%$ & $8 \%$ & $6 \%$ \\
\hline $\mathrm{X}$ & $1 \mathrm{C}$ & $C W$ & 5 & $0 \%$ & $6 \%$ & $2 \%$ & $1 \%$ & $2 \%$ \\
\hline XI & DSSF & NCPLX & 4 & $7 \%$ & $3 \%$ & $2 \%$ & $12 \%$ & $6 \%$ \\
\hline XII & $1 \mathrm{C}$ & TBP & 4 & $0 \%$ & $6 \%$ & $0 \%$ & $1 \%$ & $2 \%$ \\
\hline XIII & TBP-F & $1 C$ & 4 & $0 \%$ & $2 \%$ & $1 \%$ & $1 \%$ & $1 \%$ \\
\hline $\mathrm{XIV}$ & HS & & 4 & $0 \%$ & $0 \%$ & $0 \%$ & $0 \%$ & $0 \%$ \\
\hline$X V$ & $2 \mathrm{C}$ & 224 & 3 & $0 \%$ & $7 \%$ & $2 \%$ & $1 \%$ & $2 \%$ \\
\hline XVI & $2 \mathrm{C}$ & $5-6$ & 3 & $0 \%$ & $4 \%$ & $1 \%$ & $1 \%$ & $1 \%$ \\
\hline XVII & $\mathrm{CW}$ & MIX & 3 & $0 \%$ & $1 \%$ & $3 \%$ & $0 \%$ & $0 \%$ \\
\hline XVIII & $\mathrm{CW}$ & & 3 & $0 \%$ & $0 \%$ & $1 \%$ & $0 \%$ & $0 \%$ \\
\hline XIX & TBP & EB-ITS & 2 & $3 \%$ & $1 \%$ & $0 \%$ & $2 \%$ & $2 \%$ \\
\hline $\mathrm{XX}$ & SRS & SR-WASH & 2 & $0 \%$ & $2 \%$ & $29 \%$ & $0 \%$ & $1 \%$ \\
\hline XXI & TBP & $\mathrm{EB}$ & 2 & $0 \%$ & $2 \%$ & $0 \%$ & $0 \%$ & $1 \%$ \\
\hline XXII & TBP & $1 \mathrm{C}-\mathrm{F}$ & 2 & $0 \%$ & $2 \%$ & $1 \%$ & $0 \%$ & $1 \%$ \\
\hline XXIII & CCPLX & DSSF & 2 & $1 \%$ & $0 \%$ & $1 \%$ & $1 \%$ & $0 \%$ \\
\hline XXIV & $\mathrm{R}$ & DIA & 2 & $0 \%$ & $1 \%$ & $0 \%$ & $0 \%$ & $0 \%$ \\
\hline \multicolumn{3}{|c|}{ Total } & 133 & $99 \%$ & $82 \%$ & $98 \%$ & $97 \%$ & $93 \%$ \\
\hline $\mathrm{XXV}$ & \multicolumn{2}{|c|}{ Ungrouped Tanks } & 16 & $1 \%$ & $18 \%$ & $2 \%$ & $3 \%$ & $7 \%$ \\
\hline
\end{tabular}

A review of Table 3.2 will quickly reveal that Group I is by far the most significant group. This group includes 22 tanks, $37 \%$ of the total salt cake volume, and over one-quarter of the total waste in all 149 SSTs. The first three groups represent over one-half of the total waste volume in all 149 SSTs. This categorization demonstrates the potential usefulness of the SORWT model in making management decisions. Table 3.2 also identifies groups that have relatively no significance, such as Groups XIV 
and XVIII, which contain almost no waste. This information can be used in allocating time and resources for characterization activities, pretreatment, and immobilization development.

Larger families of related tank groups may exist. An example of a potential family is Group I (R, EB) and Group IX (EB, R). These two groups have the same primary and secondary waste types. The relative differences between these two groups are due to their respective designation for primary and secondary waste types. The differences caused by prioritizing the same waste types in different orders may be small compared with the overall group variability. Identifying larger families of tanks will reduce the overall number of different groups being evaluated and potential sampling and analysis events. The existence of families could be tested and reported at a later time.

\subsection{Description of SORWT Waste-Type Groups}

This section gives brief descriptions of each of the waste-type groups predicted by the model.

\subsubsection{Group I - R, EB}

This waste-type group is the most significant group predicted by SORWT in terms of number of tanks and total waste volume. The 22 tanks within this group contain an estimated 10,082,000 gallons of total waste consisting of 8,522,000 gallons of salt cake and 1,438,000 gallons of sludge. All 22 Group I tanks can be found in three different 200 West Area Tank Farms, S, SX, and TX. These tanks typically received a large amount of high-level REDOX waste (R) during the 1950s. This waste is most likely responsible for the sludge accumulation in these tanks. These tanks also received large amounts of evaporator bottoms (EB), usually from the 242-S Evaporator in the early 1970s. This supersaturated, high-nitrate waste cooled in the SSTs and formed an extremely hard salt cake. Despite the slightly different processing history of these tanks between the addition of the $R$ in the 1950s and the EB in the 1970s, it is believed that these two waste types predominantly dictate the physical and

chemical characteristics of the waste. Some of the tanks in this group have no reported sludge accumulation, probably because poor measurements were taken before salt cake formation. Once the salt cake crystallized in a tank, it became impossible to measure the volume of sludge.

\subsubsection{Group II - EB, 1C}

This 10-tank group contains approximately 4,634,000 gallons of waste. The vast majority of this waste-4,594,000 gallons-is salt cake. All but two of these tanks are located in the TX Tank Farm; one is located in B Tank Farm and the other in TY Tank Farm. These tanks are characterized as having received large quantities of EB, mainly from the 242-T Evaporator. They also received modest quantities of first decontamination cycle $(1 \mathrm{C})$ waste. Tank B-105 received $1 \mathrm{C}$ before the EB, which probably explains the limited sludge accumulation in this tank that is not exhibited by the others. 


\subsubsection{Group III - TBP-F, EB-ITS}

This group contains 10 tanks and is the third most significant in terms of number of tanks and total waste volume. The tanks in this group hold 3,980,00 gallons of waste. The majority of this waste-3,344,000 gallons -is presumed to be salt cake. However, these tanks also contain substantial amounts of sludge. All 10 of these tanks, which originally held wastes from the $\mathrm{BiPO}_{4}$ process [mostly $1 \mathrm{C}$ with some metal waste (MW)], can be found in the BY Farm located in the 200 East Area. They were completely emptied in the early $1950 \mathrm{~s}$, and no significant amounts of $\mathrm{BiPO}_{4}$ solids remain in the tanks, so the presence of that waste type is not considered by the SORWT model. After sluicing, these tanks received tributyl phosphate (TBP) ferrocyanide-scavenged (F) waste from U Plant, which is probably responsible for the sludge buildup. During the late 1960s and early 1970s, these tanks were connected to the in-tank solidification (ITS-2) loops. This process, in which one tank in the loop was used as an in-tank evaporator and the rest of the tanks as liquid holders, concentrated the waste and reduced the liquid volume, resulting in salt cake formation.

\subsubsection{Group IV - R}

Group IV is a 10-tank group containing high-level $R$ waste. S-104 received $R$ waste which still contained cladding waste (CW); all other tanks were filled with $\mathrm{R}$ waste only after the $\mathrm{CW}$ was removed. Tanks SX-111 and SX-114 received a small amount of EB waste from the REDOX waste evaporator but not in sufficient concentrations to support crystal formation.

Group IV tanks hold 1,232,000 gallons of waste. The majority of waste-1,228,000 gallons-is sludge; no salt cake formation has been observed. Eight of these tanks can be found in the SX Tank Farm, and all are located in the 200 West Area. There are no safety or technical sampling issues associated with the majority of this group; the exception is Tank SX-109, which is on the watch list as a gas-generating tank. It should also be mentioned that Hanlon (1994) currently lists the volume of SX-109 as salt cake but is in the process of being revised to indicate the volume is actually sludge as shown in Appendix A. Sampling and analysis of S-104 have been performed; assessment of the data has contributed greatly to the existing body of characterization knowledge. The analysis of this tank significantly aids in characterizing this particular 10-tank group and also several other groups containing large amounts of R-type waste.

\subsubsection{Group V - TBP, CW}

This nine-tank group, located almost entirely in BX Tank Farm, contains 708,000 gallons of waste. Nearly all of the contents of this group is sludge. Salt cake has only been observed in one tank, BX-105. The 3000 gallons of salt cake are due to a small transfer of EB into BX-105. These tanks were originally filled with MW or 1C in the 1940s. In the early 1950s MW tanks were sluiced and other tanks were pumped down to provide room for TBP waste. Additions of this waste type began in the mid-1950s. The addition of CW began in the mid-1960s. The various other transfers that occurred in these tanks should not significantly affect the characteristics of the waste relative to TBP and CW, 
the primary and secondary wastes. Tanks BX-104 and BX-105 were core-sampled previously (1985), and the results provide some insight into their chemical composition; however no recent (post-1989) characterization data have been obtained from this group.

\subsubsection{Group VI - EB, CW}

These eight tanks contain 2,306,000 gallons of waste. Salt cake comprises $1,877,000$ gallons of this waste, while sludge comprises only 314,000 gallons. All of these tanks except TX-118 were filled with MW in the late 1940s or early 1950s; in the mid- to late 1950s, the MW was sluiced from the tanks to recover the uranium. The order that the tanks then received $\mathrm{EB}$ and $\mathrm{CW}$ varies, but the current volumes indicate that EB and $\mathrm{CW}$ are the primary and secondary waste types, respectively.

\subsubsection{Group VII - 224}

This eight-tank group represents 280,000 gallons of waste. The majority of the waste is sludge, and although some of these tanks received high-level B Plant waste from the bottom of Section 5 (5-6), no salt cake formation has been observed. All eight tanks are 55,000-gallon, 200 Series tanks located in B and T Tank Farms. These tanks received lanthanum fluoride decontamination (224) waste exclusively. In light of the singularity of the waste type introduced into these tanks and the similarity of process history (i.e., the near absence of any inter-tank transfers), the composition among the tanks of this group should be very uniform. Two tanks, B-201 and B-202, were core-sampled and analyzed in 1992. The data from these tanks have been used as part of the statistical verification study.

\subsubsection{Group VIII - 1C, EB}

This six-tank group of B and BX Farm tanks contains 960,000 gallons of waste, a large percentage of which is sludge. These tanks all received $1 \mathrm{C}$ waste in the late 1940s and early 1950s. In the mid1950 s, the supernatant portion of the $1 \mathrm{C}$ waste was transferred from the tanks and they began receiving EB waste. All of these tanks also received appreciable amounts of CW in the 1960s.

Tank BX-111 is the only tank in the group which exhibits a greater amount of salt cake $(143,000$ gallons) than sludge $(68,000$ gallons). This may be a result of imprecise sludge measurements during the early history of the tank, or it may indicate real differences between BX-111 and the other tanks in Group VIII. This observation cannot be properly addressed until one or more of the tanks in the group have been core sampled.

\subsubsection{Group IX - EB, R}

Group IX consists of five 200 West Area tanks, mostly from U Farm. These tanks contain $2,037,000$ gallons of waste, with the vast majority as salt cake. Initially, these tanks held substantial amounts of supernatant before receiving solid wastes. Some tanks were filled with MW in the 1940s, but these MW receivers were completely sluiced out in the early 1950s. Large quantities of high-level $\mathrm{R}$ were then introduced into these tanks and allowed to remain there for many years. In the 
early 1970s, large volumes of R supernatant were transferred from the tanks and replaced with EB from the 242-S Evaporator, which caused a salt cake to form in the majority of the tanks. The small amount of sludge that accumulated in these tanks is probably due to the R present before the EB. Because of the hardness of the salt cake, these tanks present technical difficulties that must be solved before sampling. These tanks should be very similar to Group I tanks and differ from them mainly in the ratios of $\mathrm{R}$ to $\mathrm{EB}$. These tanks might be so similar that they can be included with that group; however, these similarities can only be verified by core samples.

\subsubsection{Group X - 1C, CW}

This five-tank group contains 760,000 gallons of waste, the majority of which, 749,000 gallons, is sludge. No salt cake has been observed in these tanks. T-105, T-106, and U-110 initially received second decontamination cycle waste $(2 \mathrm{C})$ waste in 1947 . The cascade was then filled with $1 \mathrm{C}$ waste from 1948 until 1955 when it began receiving CW in large quantities. C-107 and T-107 both initially received $1 \mathrm{C}$ waste but eventually began receiving CW waste in the $1960 \mathrm{~s}$. A large amount of solids accumulated from these waste types. In the 1970s, a number of different liquid wastes were transferred through these tanks but did not affect the solids content to the degree of the previous wastes.

\subsubsection{Group XI - DSSF, NCPLX}

This four-tank group contains a total of 2,113,000 gallons of waste. Salt cake comprises $1,717,000$ gallons of this waste, while 387,000 gallons are sludge. These tanks initially received either plutonium-uranium extraction (PUREX); high-activity, neutralized acid waste (P); or B Plant high-level waste from waste fractionization process (B). However, all of these tanks were sluiced of their contents in 1976. The waste types added to these tanks after sluicing were double shell slurry feed (DSSF) and noncomplexed (NCPLX) waste, which are generic terms describing the potential for further processing of the waste instead of the original source of the waste. Because these terms are so general, little can be determined about the homogeneity of the waste in this group. Although the total volume of waste in this group is significant, the high degree of uncertainty regarding the waste types in these tanks makes this group questionable, and different affiliations for these tanks may be found. However, it is also possible that the volume of waste reported for Tank A-103 is actually salt cake since the waste did pass through the 242-A Evaporator/Crystallizer. This would increase the probability that Group XI is a legitimate group, but this can only be verified by sampling Tank A-103.

\subsubsection{Group XII - 1C, TBP}

This four-tank group contains 693,000 gallons of waste, the vast majority of which is sludge. Even though this group transcends four different tank farms in both the 200 East and West Areas, these tanks have very similar processing histories. They were filled with 1C waste in the 1940s. A portion of this volume was drained in the early 1950s, and the tanks began receiving TBP waste. The solids volume that was measured at this time did not accumulate further during the rest of the history of these tanks.

The additional transfers were mostly liquid in nature and had little effect on the sludge volume. No salt 
cake has been observed in these tanks, even though records indicate a small amount of EB was introduced into T-108. Two of these tanks, $\mathrm{C}-110$ and $\mathrm{BX}-107$, have been core sampled and are included in the statistical verification study.

\subsubsection{Group XIII - TBP-F, 1C}

This four-tank group contains 293,000 gallons of waste, and approximately 289,000 gallons are sludge. No salt cake has been observed in these tanks. The tanks were used as the primary settling tanks during the In-Farm Scavenging campaign during the 1950s, and they were originally filled with $1 \mathrm{C}$ waste in the 1940s. The supernatant was transferred out of the tanks to make room for the TBP-F waste that was allowed to settle. These two wastes formed the vast majority of the solids located in these tanks. All of these tanks are on the watch list because of their ferrocyanide content.

\subsubsection{Group XIV - HS}

This four-tank group of 55,000-gallon, 200-Series tanks is located in the C Tank Farm. These tanks received MW in the 1940s but were sluiced in the early 1950s. After sluicing, these tanks received waste only from the Hot Semiworks (HS). The majority of this waste was removed from these tanks in the late 1960 s and early 1970s; the total waste remaining is only 11,000 gallons. This minor volume designates this tank group as being insignificant compared with other groups or even single tanks.

\subsubsection{Group XV - 2C, 224}

This three-tank group contains 904,000 gallons of total waste, the majority of which, 892,000 gallons, is sludge. These SSTs were connected in a three-tank cascade. The processing history of these tanks is very similar. They all received 2C waste in the 1940s and early 1950s until the cascade was full. In 1952, they began receiving 224 waste, and the excess supernatant was cascaded to a crib. The cascade also received 5-6 waste after 1951 and Tanks T-111 and T-112 received dilute decontamination waste (DW) and a mixture of liquid wastes (MIX) in the late 1960s. These transfers would not have significantly altered the characteristics of the waste relative to the first two waste types. Tank $\mathrm{T}-110$ is on the watch list for gas generation. $\mathrm{T}-111$ is on the organic watch list, but has been core sampled and is included in the statistical verification study.

\subsubsection{Group XVI - 2C, 5-6}

This three-tank group, located in the B Tank Farm of the 200 East Area, contains 516,000 gallons of waste. The majority of waste-511,000 gallons-is sludge. These three tanks also were connected in a three-tank cascade. The cascade was originally filled with $2 \mathrm{C}$ waste in the $1940 \mathrm{~s}$, cribbed in 1950 , and refilled with $2 \mathrm{C}$ waste. The continuous overflow in B-112 was cribbed. The cascade began receiving 5-6 waste in 1952 as part of the shutdown and decontamination of B Plant. The tanks began receiving fission products in 1963. B Plant low-level waste (BL) and ion exchange waste (IX) were routed to the cascade in the late 1960 s and early 1970 s, but these were mostly liquid in nature and are 
not considered significant contributors to the physical and chemical characteristics of the solids remaining in the tank, relative to the previous three wastes. Tank B-112 received significant EB and recycle from the ITS loop. This EB-ITS waste did not cause the formation of salt cake typically exhibited by this waste form, or perhaps any salt cake that was formed was subsequently dissolved by waste transfers after the EB-ITS transfers. Seven cores from Tank B-110, obtained in 1989 and 1990, underwent extensive analytical testing and provide excellent data for physical and chemical characterization of this group. Tank B-111 has also been core sampled, and a comparison of the two tanks shows substantial agreement for the primary analytes (Remund et al. 1994).

\subsubsection{Group XVII - CW, MIX}

This three-tank cascade currently holds 161,000 gallons of waste, most of which $(143,000$ gallons) is sludge. No salt cake has been observed in these tanks. The cascade was initially filled with MW in the 1940s and emptied in 1951. Tank T-101 received a small amount of TBP-F waste from a pilotplant test of the process; this waste was then pumped to a minimum level and flushed from the tank. The cascade was again filled with MW in 1955 but sluiced empty the following year. Tank T-101 is listed as a ferrocyanide tank, but this waste was removed, and the tank was sluiced empty later so it is unlikely that any appreciable amount of ferrocyanide remains. The empty cascade was then filled with CW beginning in 1957 . This single waste type remained until the early 1970 s, when a mixture of several miscellaneous liquid wastes was routed to these tanks. The liquid wastes are considered to have had only a limited impact on the characteristics of the solid waste remaining in the tank.

\subsubsection{Group XVIII - CW}

These three 200-Series tanks from U Farm contain only 13,000 gallons of waste. The history of these tanks indicates that the predominant waste type is CW. The small amount of waste contained in these tanks makes this group a poor choice for sampling, if inventory volume is a selection criterion. However, because of the straightforward process history of these tanks, adequate representation of $\mathrm{CW}$ (that may be extended to other tanks) may be achieved.

\subsubsection{Group XIX - TBP, EB-ITS}

This pair of BY Farm tanks contains a combined total of 764,000 gallons of waste. The majority of this waste-681,000 gallons-is salt cake, while 83,000 gallons are sludge. Both tanks received MW supernatants before 1955 , but the tanks were sluiced to recover any residual solids that may have been suspended and eventually settled. Beginning in 1955, both tanks received TBP waste. Both tanks received quantities of CW in the early 1960 s and were connected to an ITS loop in the late 1960s; Tank BY-102 to ITS-1 and BY-109 to ITS-2. Despite being connected to different ITS loops (operated by different principles), the solids remaining in the two tanks, both salt cake and sludge, can be expected to be relatively similar. 


\subsubsection{Group XX - SRS, SR-WASH}

Both of the tanks in this group are located in C Farm and contain 424,000 gallons of waste, the bulk of which-259,000 gallons-is sludge. This group received MW in the 1940s, which was removed in the early 1950s. The tanks were then filled with TBP waste that was scavenged in the CR vault in the mid-1950s. Also during the mid-1950s, these tanks received various quantities of $P$ and $C W$. In the early 1970s, these tanks received large quantities of a variety of liquid waste, which was later transferred out. This liquid probably did not greatly affect the solids. In 1976 and 1977 , these tanks received a large transfer of strontium leached sludge (SRS), which greatly added to the solids volume in the tank. These tanks also received a large quantity of high-level solids as suspended particulates from sludge washing in the AR vault (SR-WASH). These suspended solids settled in the tanks and are considered a significant contributor to the solids characteristics and high radioactivity. Both of the tanks .were previously core sampled. Tank C-103 is on the watch list as an "organic" tank, because it has a separate organic liquid layer. Tank C-106 is on the same list as a "high heat" tank.

\subsubsection{Group XXI - TBP, EB}

These two 200 West Area tanks hold a total of 215,000 gallons of waste, all of which is sludge. Although these tanks received an appreciable amount of EB, the characteristic salt cake did not form or was washed away.

\subsubsection{Group XXII - TBP, 1C-F}

This pair of ferrocyanide tanks is located in TY Farm and contains 208,000 gallons of waste; 205,000 gallons are sludge. No salt cake has been observed in these tanks. These tanks received TBP waste in the early 1950s, then, during the mid-1950s, the supernatant was transferred out and $1 \mathrm{C}-\mathrm{F}$ waste placed on top of the TBP heel. These two waste types caused significant solids accumulation. During the 1960s and 1970s, a variety of waste was transferred into and out of these tanks. The solids accumulation did not substantially change during these transfers; therefore, these later transfers are not considered to have significantly affected the physical and chemical characteristics of the solids already present in the tank. Both of these tanks have been previously sampled.

\subsubsection{Group XXIII - CCPLX, DSSF}

This group of two AX Farm tanks contains 151,000 gallons of waste, consisting of 139,000 gallons of salt cake, 9000 gallons of sludge, and the remainder supernatant liquid. Both of these tanks were sluiced of their contents in 1977, leaving a 6000-gallon heel of P waste. The tanks then received wastes identified by unspecific waste names like complex concentrate (CCPLX), DSSF, and post-1.976 evaporator feed (EVAP). Using such broad waste identifiers-based on suitability for further treatment, not waste source-precludes grouping by radioactive waste type. 


\subsubsection{Group XXIV - R, DIA}

This pair of assumed leaker tanks contains 148,000 gallons of waste, all of which is sludge. Tank U-104 initially received MW in the 1940s, but this waste type was sluiced from the tank in the early 1950s. Tank SX-113 was not released to operation until the mid-1950s. Both tanks exclusively received $\mathrm{R}$ after 1958. Diatomaceous earth (DIA) was added to both tanks after they were declared leakers, in an attempt to prevent the escape of liquid waste.

\subsubsection{Group XXV - Solitary Tanks (Ungrouped)}

Of the 149 SSTs, only 16 did not fall into groups based on radioactive waste types. These 16 tanks transcend almost every waste type and every tank farm in the 200 East and West Areas. They contain mostly sludge. These ungrouped tanks represent 2,502,000 gallons of waste-203,000 gallons of salt cake and 2,287,000 gallons of sludge. Several of these tanks have significant quantities of waste in them, while others have relatively little waste. Many of these tanks are probably related to some of the groups previously described. 
,

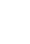

•

:

- 


\subsection{Statistical Verification of the SORWT Model}

The validity of the SORWT grouping model was tested by performing a statistical analysis verification study on a limited amount of core sample data, which came from earlier studies (Winters et al. 1989, 1990; Hill et al. 1991). It is important to note that, at the time these core samples were collected, there existed only the capability to sample relatively soft sludge-like wastes. Therefore, the statistical verification study is based upon core sample and analysis data from only sludge wastes and does not, at this time, include data from salt cake wastes. Furthermore, the core data used in the verification study was the core composite data. Core composites are composed of homogenized aliquots of segment material from various depths.

Evaluation of the SORWT model was only one of the driving factors in tank selection. The full rationale and justification for the requested core samples can be found in Hill et al. (1991). Due to sampling difficulties and changes in programmatic priorities, not all of the tanks requested for sampling in Hill et al. (1991) were actually sampled.

This section outlines the approach used for evaluating the model, including the analytical data sources, a graphical description of the data set, a summary of the characteristics of the waste types, and the analysis of variance (ANOVA) results and descriptive statistics of the grouped data.

\subsection{Approach to Verification of the SORWT Model}

Once the analytical results were arranged into groups as predicted by the SORWT model (as discussed in Section 3), an ANOVA was performed on the grouped data for a selected number of analytes. An ANOVA is a quantitative method to test the significance of the effect a particular treatment has on the response or dependent variable. In the SORWT model verification study, the treatment being studied is SORWT groups, and the dependent variable is analyte concentration. The ANOVA method was used to test whether the mean concentration of a particular SORWT group is statistically significantly different from the mean concentration of other SORWT groups. The null hypothesis tested by this statistical model was as follows:

The deviations between the means of the different groups were due only to random variation within the entire data set.

If the null hypothesis was proved valid, then no group effects were present, and the SORWT model would be discredited. However, if the null hypothesis was proved incorrect, then the converse would be true (i.e., group effects are present and the SORWT model methodology is supported by the data). If significant group effects were observed, a Tukey pairwise comparison was conducted to investigate groups that differed significantly from the others.

In addition to the ANOVA, the magnitude of the individual analyte variances within the SORWT groups was investigated. These variances were compared to the variance results for the entire 
ungrouped data set. A reduction in the individual analyte variances by grouping the data according to SORWT further suggests that the SORWT model accurately predicts tank groups that exhibit similar chemical concentrations.

\subsubsection{Analytical Data Sources for the Verification Study}

The analytical results data utilized in the SORWT model verification study were obtained from the official core sample data packages produced by the Hanford analytical laboratories in support of the WHC Tank Waste Characterization Program. The SSTs and SORWT groups that were used in the verification study can be found in Table 4.1. The associated source documents from which analytical results data were obtained are summarized in Table 4.2. Tanks C-112, C-109, U-110, and T-107 were also core sampled. Although C-112 and C-109 were predicted to belong to the same SORWT group, incomplete sampling recoveries, a more complex waste processing history, and in-tank aging resulted in analytical data exhibiting larger than normal variability for most analytes. These dissimilarities are discussed in the respective tank characterization reports for these tanks (Simpson et al. $1993 \mathrm{a}, \mathrm{b}$ ). U-110 was not included in the verification study because of uncertainty in the accuracy of the data. The U-110 cores were the first samples to be analyzed and there were significant problems in extracting the cores from the tank. T-107 was excluded from the SORWT model evaluation because of difficulties in sample recovery and incompleteness of the data set.

When the C-112 and C-109 (Group XIII) data were included in the data set, the ANOVA study showed that only Group XIII was significantly different from the remaining groups. The differences among the remaining groups were masked by the substantially larger variability in the Group XIII data. When the Group XIII data were not included in the data set, the significance of the differences between the SORWT groups could be tested against a more reasonable residual variability. Because of the disparate nature of the data associated with these tanks and the masking effect on the ANOVA study, C-112 and C-109 were not included in the statistical verification study.

Table 4.1. SORWT Groups and Tanks Included in Verification Study

\begin{tabular}{||c|c|c|c||}
\hline Group No. & Tank No. & $\begin{array}{c}\text { Primary } \\
\text { Waste Type }\end{array}$ & $\begin{array}{c}\text { Secondary } \\
\text { Waste Type }\end{array}$ \\
\hline \hline VII & B-201 & 224 & \\
\hline B-202 & S-104 & R & \\
\hline XII & C-110 & 1 C & TBP \\
& BX-107 & & 224 \\
\hline XV & T-111 & 2C & $5-6$ \\
\hline XVI & B-110 & 2C & \\
\hline \hline
\end{tabular}


Table 4.2. Core Sample Analytical Data Sources

\begin{tabular}{|c|c|c|c|}
\hline Group No. & Tank No. & Core No. & Source \\
\hline XII & C-110 & 37 & $\begin{array}{l}\text { Remund, K. M., L. Jensen. Statistical Characterization Report for Single- } \\
\text { Shell Tank 241-C-110. Rev. 0. WHC-SD-WM-TI-585, Westinghouse } \\
\text { Hanford Company, Richland, Washington. }\end{array}$ \\
\hline XII & C-110 & 38 & $\begin{array}{l}\text { Remund, K. M., L. Jensen. Statistical Characterization Report for Single- } \\
\text { Shell Tank 241-C-110. Rev. 0. WHC-SD-WM-TI-585, Westinghouse } \\
\text { Hanford Company, Richland, Washington. }\end{array}$ \\
\hline XII & C-110 & 39 & $\begin{array}{l}\text { Remund, K. M., L. Jensen. Statistical Characterization Report for Single- } \\
\text { Shell Tank 241-C-110. Rev. 0. WHC-SD-WM-TI-585, Westinghouse } \\
\text { Hanford Company, Richland, Washington. }\end{array}$ \\
\hline$\overline{X I I}$ & BX-107 & 40 & WHC-EP-0739, Westinghouse Hanford Company, Richland, Washington. \\
\hline XII & BX-107 & 40 & $\begin{array}{l}\text { WHC-SD-WM-TI-603, Rev. 0, Westinghouse Hanford Company, Richland, } \\
\text { Washington. }\end{array}$ \\
\hline XII & BX-107 & $\overline{41}$ & WHC-EP-0739, Westinghouse Hanford Company, Richland, Washington. \\
\hline XII & BX-107 & 41 & $\begin{array}{l}\text { WHC-SC-WM-TI-603, Rev. 0, Westinghouse Hanford Company, Richland, } \\
\text { Washington. }\end{array}$ \\
\hline VII & B-201 & 26 & $\begin{array}{l}\text { June 27, 1992. SST Waste Characterization Project: Core } 26 . \\
\text { Addendum 1A. Rev. 0. WHC-SD-WM-DP-037, Westinghouse Hanford } \\
\text { Company, Richland, Washington. }\end{array}$ \\
\hline VII & B-201 & 27 & $\begin{array}{l}\text { June 27, 1992. SST Waste Characterization Project: Core } 27 . \\
\text { Addendum } 1 \text { A. Rev. 0. WHC-SD-WM-DP-037, Westinghouse Hanford } \\
\text { Company, Richland, Washington. }\end{array}$ \\
\hline VII & B-202 & 24 & $\begin{array}{l}\text { Ottmar, L., T. Frazier. January 23, 1992. 222-S Laboratory Analytical } \\
\text { Batch: Core 24, Comp 1. Rev. 0. WHC-SD-WM-DP-034, Westinghouse } \\
\text { Hanford Company, Richland, Washington. }\end{array}$ \\
\hline VII & B-202 & 24 & $\begin{array}{l}\text { Ottmar, L., T. Frazier. January 23, 1992. 222-S Laboratory Analytical } \\
\text { Batch: Core 24, Comp 2. Rev. 0. WHC-SD-WM-DP-034, Westinghouse } \\
\text { Hanford Company, Richland, Washington. }\end{array}$ \\
\hline VII & B-202 & 24 & $\begin{array}{l}\text { Wels, B., S. K. McFarland. June 11, 1992. 222-S Laboratory Analytical } \\
\text { Batch: Core 24, Comp 1-Rework. Rev. 0. WHC-SD-WM-DP-034, } \\
\text { Westinghouse Hanford Company, Richland, Washington. }\end{array}$ \\
\hline VII & B-202 & 25 & $\begin{array}{l}\text { Ottmar, L., T. Frazier. January 23, 1992. 222-S Laboratory Analytical } \\
\text { Batch: Core 25, Comp 1. Rev. 0. WHC-SD-WM-DP-034, Westinghouse } \\
\text { Hanford Company, Richland, Washington. }\end{array}$ \\
\hline VII & B-202 & 25 & $\begin{array}{l}\text { Ottmar, L., T. Frazier. January 23, 1992. 222-S Laboratory Analytical } \\
\text { Batch: Core 25, Comp 2. Rev. 0. WHC-SD-WM-DP-034, Westinghouse } \\
\text { Hanford Company, Richland, Washington. }\end{array}$ \\
\hline VII & B-202 & 25 & $\begin{array}{l}\text { Wels, B., S. McFarland. June 11, 1992. 222-S Laboratory Analytical Batch: } \\
\text { Core 25, Comp 2-Rework. Rev. 0. WHC-SD-WM-DP-034, Westinghouse } \\
\text { Hanford Company, Richland, Washington. }\end{array}$ \\
\hline XVI & B-110 & 1 & $\begin{array}{l}\text { Jones, T. E. May 14, 1990. SST Waste Characterization Project: Core } 1 \\
\text { Data Report. Rev. 2. Pacific Northwest Laboratory, Richland, Washington. }\end{array}$ \\
\hline
\end{tabular}


Table 4.2. (contd)

\begin{tabular}{|c|c|c|c|}
\hline Group No. & Tank No. & Core No. & Source \\
\hline XVI & B-110 & 2 & $\begin{array}{l}\text { Jones, T. E., S. G. McKinley, J. M. Tingey, T. M. Longaker, J. A. Gibson. } \\
\text { October 2, 1990. SST Waste Characterization Project: Core } 2 \text { Data Report. } \\
\text { Rev. 1. Pacific Northwest Laboratory, Richland, Washington. }\end{array}$ \\
\hline XVI & B-110 & 3 & $\begin{array}{l}\text { Jones, T. E., S. G. McKinley, J. M. Tingey, T. M. Longaker. September 7, } \\
\text { 1990. SST Waste Characterization Report: Core } 3 \text { Data Report. Rev. } 1 . \\
\text { Pacific Northwest Laboratory, Richland, Washington. }\end{array}$ \\
\hline XVI & B-110 & 4 & $\begin{array}{l}\text { Jones, T. E., S. G. McKinley, J. M. Tingey, T. M. Longaker, J. A. Gibson. } \\
\text { October 19, 1990. SST Waste Characterization Report: Core } 4 \text { Data Report. } \\
\text { Rev. 1. Pacific Northwest Laboratory, Richland, Washington. }\end{array}$ \\
\hline XVI & B-110 & 9 & $\begin{array}{l}\text { Jones, T. E., S. G. McKinley, J. M. Tingey, T. M. Longaker, J. A. Gibson. } \\
\text { December 5, 1990. SST Waste Characterization Report: Core } 9 \text { Data Report. } \\
\text { Rev. 0. Pacific Northwest Laboratory, Richland, Washington. }\end{array}$ \\
\hline XVI & B-110 & 10 & $\begin{array}{l}\text { Jones, T. E., S. G. McKinley, J. M. Tingey, T. M. Longaker, J. A. Gibson. } \\
\text { January 7, 1990. SST Waste Characterization Report: Core 10 Data Report. } \\
\text { Rev. 0. Pacific Northwest Laboratory, Richland, Washington. }\end{array}$ \\
\hline XVI & B-110 & 16 & $\begin{array}{l}\text { Jones, T. E., S. G. McKinley, J. M. Tingey, T. M. Longaker, J. A. Gibson, } \\
\text { B. M. Thornton. February 19, 1990. SST Waste Characterization Report: } \\
\text { Core } 16 \text { Data Report. Rev. 0. Pacific Northwest Laboratory, Richland, } \\
\text { Washington. }\end{array}$ \\
\hline XVI & B-111 & 29 & $\begin{array}{l}\text { McKinley, S. G., L. R. Greenwood, E. W. Hoppe, R. T. Steele, J. M. } \\
\text { Tingey, M. W. Urie. June 30, 1990. SST Waste Characterization Project: } \\
\text { Cores } 29 \text { \& } 30 \text { Data Report. Rev. 0. Pacific Northwest Laboratory, } \\
\text { Richland, Washington. }\end{array}$ \\
\hline XVI & B-111 & 29 & $\begin{array}{l}\text { April 15, 1993. SST Waste Characterization Project: Core } 29 . \\
\text { Addendum 1A. Rev. 0. WHC-SD-WM-DP-041, Westinghouse Hanford } \\
\text { Company, Richland, Washington. }\end{array}$ \\
\hline XVI & B-111 & 30 & $\begin{array}{l}\text { McKinley, S. G., L. R. Greenwood, E. W. Hoppe, R. T. Steele, } \\
\text { J. M. Tingey, M. W. Urie. June 30, 1990. SST Waste Characterization } \\
\text { Project: Cores } 29 \text { \& } 30 \text { Data Report. Rev. 0. Pacific Northwest Laboratory, } \\
\text { Richland, Washington. }\end{array}$ \\
\hline IV & S-104 & 42 & $\begin{array}{l}\text { WHC-SD-WM-DP-031, Rev. 0, Westinghouse Hanford Company, Richland, } \\
\text { Washington. }\end{array}$ \\
\hline IV & S-104 & 43 & $\begin{array}{l}\text { WHC-SD-WM-DP-031, Rev. 0, Westinghouse Hanford Company, Richland, } \\
\text { Washington. }\end{array}$ \\
\hline IV & S-104 & 44 & $\begin{array}{l}\text { WHC-SD-WM-DP-031, Rev. 0, Westinghouse Hanford Company, Richland, } \\
\text { Washington. }\end{array}$ \\
\hline$X V$ & T-111 & 31 & $\begin{array}{l}\text { WHC-SD-WM-DP-024, Westinghouse Hanford Company, Richland, } \\
\text { Washington. }\end{array}$ \\
\hline$X V$ & $\mathrm{~T}-111$ & 33 & $\begin{array}{l}\text { WHC-SD-WM-DP-024, Westinghouse Hanford Company, Richland, } \\
\text { Washington. }\end{array}$ \\
\hline
\end{tabular}


This situation may likely occur in the future due to the incomplete and sometime contradictory nature of some of the source data used in the sorting methodology, as well as deficiencies in the sampling and analytical procedures. However, it is expected that the majority of the tanks have been accurately grouped using the SORWT methodology. In the case of C-112 and C-109, it is uncertain what revisions to the tank groups should be made at this time. There are several possible outcomes. 1) This could be a poor group and all tanks should be shifted to the ungrouped category. 2) One of these tanks does not group with the others and only this tank should be shifted to the ungrouped category. It is impossible to know at this time which tank would not belong. 3) This is still a group, but the within group variability is large. The remaining tanks in this group have all been core sampled. When the analytical data on these samples are available, the appropriate response can be determined.

The core sample data packages contain a great deal of analytical data measured using several alternative digestion methods and analytical instrumentation. These measurements were often taken both on segment level aliquots and on core composites, which represent the nominal or average composition of an entire core. Since the SORWT model verification study is interested in comparing the differences between the mean nominal composition of one group versus the mean nominal composition of other groups, only core composite data for the analytes that significantly contribute to the overall character of the waste were considered. The analytes included in the verification study, along with the sample preparation method and analytical instrumentation, are presented in Table 4.3.

The analytical results data for the tanks and analytes included in the verification study were entered into a spreadsheet. The spreadsheet datafile used in the statistical analyses has been included in Appendix C. The first column identifies the SORWT group to which a tank belongs. Column 2 identifies the tank from which a particular core was sampled. Column 3 presents the core number of the analyzed sample. Core numbers have been assigned sequentially for each core sampled from Hanford Site waste tanks since 1989. Columns 4 and 5, respectively, identify the composite and sample from which analyses were obtained. Often, two separate but equivalent core composites were generated for a single core to investigate the ability to generate representative core composites. The analytical results for multiple core composites from a single core generally agree with one another. In addition, the analyses were conducted in duplicate for a particular sample. Occasionally, multiple samples for a single composite were analyzed. A complete set of Group No., Tank No., Core No., Composite No., and Sample No. represents a unique case of data. Columns 6 through 25 present the analytical results data for the analytes of interest. With the exception of ${ }^{137} \mathrm{Cs},{ }^{90} \mathrm{Sr}$, and ${ }^{239 / 240} \mathrm{Pu}$, which are reported in units of $\mu \mathrm{Ci} / \mathrm{g}$, all results are presented in units of $\mu \mathrm{g} / \mathrm{g}$. Column 26 presents the measured $\mathrm{pH}$ of the composite sample. The "." symbol represents missing data. If the data in the official core sample data packages were reported as below detection limit, then the detection limit was entered into the spreadsheet.

Bulk density was not reported for core composites in the data packages. Density was usually reported for each individual segment as it was extruded. Since the horizon for which density was measured is fundamentally different from the core composite analytical data, a separate spreadsheet was created for the density measurements. These data have also been presented in Appendix C. 
Table 4.3. Analytes, Sample Preparation, and Analytical Method Used in the SORWT Model Verification Study

\begin{tabular}{|c|c|c|}
\hline Analyte & Sample Digestion Method & Analytical Method \\
\hline $\mathrm{Al}$ & Fusion Dissolution & $\begin{array}{l}\text { Inductively Coupled Plasma/Atomic } \\
\text { Emission Spectroscopy (ICP/AES) }\end{array}$ \\
\hline $\mathrm{Bi}$ & Fusion Dissolution & ICP/AES \\
\hline $\mathrm{Cr}$ & Fusion Dissolution & ICP/AES \\
\hline $\mathrm{Fe}$ & Fusion Dissolution & ICP/AES \\
\hline $\mathrm{La}$ & Fusion Dissolution & ICP/AES \\
\hline Mn & Fusion Dissolution & ICP/AES \\
\hline $\mathrm{Na}$ & Fusion Dissolution & ICP/AES \\
\hline $\mathrm{Pb}$ & Fusion Dissolution & ICP/AES \\
\hline $\mathrm{Si}$ & Fusion Dissolution & ICP/AES \\
\hline $\mathrm{Zr}$ & Fusion Dissolution & ICP/AES \\
\hline $\mathrm{U}$ & Fusion Dissolution & Laser Fluorimetry \\
\hline $\mathrm{PO}_{4}(\mathrm{aq})$ & Water Digestion & Ion Chromatography \\
\hline $\mathrm{NO}_{3}$ & Water Digestion & Ion Chromatography \\
\hline $\mathrm{NO}_{2}$ & Water Digestion & Ion Chromatography \\
\hline $\mathrm{F}$ & Water Digestion & Ion Chromatography \\
\hline $\mathrm{Cl}$ & Water Digestion & Ion Chromatography \\
\hline \multirow{2}{*}{ TOC } & Water Digestion & Furnace Combustion \\
\hline & Direct Sample & Persulfate Oxidation \\
\hline${ }^{137} \mathrm{Cs}$ & Fusion Dissolution & Gamma Energy Analysis (GEA) \\
\hline${ }^{90} \mathrm{Sr}$ & Fusion Dissolution & Chemical Separations and Beta Counting \\
\hline $239 / 240 \mathrm{Pu}$ & Fusion Dissolution & Alpha Energy Analysis \\
\hline
\end{tabular}

The first column reports the SORWT Group No. to which a particular tank is predicted to belong. The second column identifies the Tank No., and the final column reports the individual density measurements for each tank. 


\subsubsection{Graphical Description of the Verification Data Set}

The data set utilized in the SORWT model verification study consists of 109 separate cases with 22 total measurements per case for a total of 2398 pieces of information to analyze. This is a rather large amount of information to assess and is only a small subset of the total data available. A useful tool for summarizing and understanding large data sets is a box plot, which is a graphical representation of the spread or variance in a given data set. Figure 4.1 is an example of a box plot for sodium (Na).

The example box plot shows the spread in the Na data for the five different SORWT groups included in the verification study. The vertical axis is Na concentration presented in units of $\mu \mathrm{g} / \mathrm{g}$. The horizontal axis represents the five different SORWT groups. The spread in the data is depicted by a box and whiskers plot. The median of a set of data is marked by a horizontal line in the box. The lower and upper hinges comprise the edges of the central box. The median splits the ordered set of data in half such that $50 \%$ of the values are above the median and $50 \%$ are below. The hinges split the remaining halves in half again such that the interior of the box represents $50 \%$ of the data. If we define the hinge-spread as the absolute value of the difference between the two values of the upper and lower hinges, the whiskers show the range in values that fall within 1.5 hinge-spreads of the hinges. Any data further than 1.5 hinge-spreads from the hinges are outliers and plotted as asterisks (*). Values that are more than three hinge-spreads away from the hinges are considered far outliers and plotted as open circles. Examples of both these types of outliers can be seen in Figure 4.1.

As can be clearly seen in the figure, the median value and range of values for analytes in some of the SORWT groups are substantially different from other SORWT groups. It is also clear that not all groups are different from one another for all analytes. It would appear that Groups XII and XVI show comparable $\mathrm{Na}$ concentrations and that Groups VII and XV are indistinguishable from one another. However, the spread of values from Groups XII and XVI do not approach the spread of values of Groups VII and XV. Group IV appears to be different from all the other groups presented.

Similar box plots were generated for each analyte included in the SORWT model verification study. These box plots have been presented as Appendix D. A review of these plots shows behavior similar to the example. The differences among groups for some of the analytes is quite striking. For aluminum, the concentration of Group IV is several times that of the other groups as would be expected for REDOX waste, since the REDOX solvent extraction process used aluminum nitrate as a salting agent. Lanthanum is another interesting plot. There is virtually no La in Groups XII, XVI, or IV, but there is a substantial concentration in Group VII and a lesser amount in Group XV. Again, this behavior is expected from process knowledge. A rare earth fraction (La) was used in a carrier precipitate in the Bismuth Phosphate 224 Building Plutonium Concentration Process, and Group VII is exclusively 224 waste, and 224 waste is the secondary waste in Group XV. 


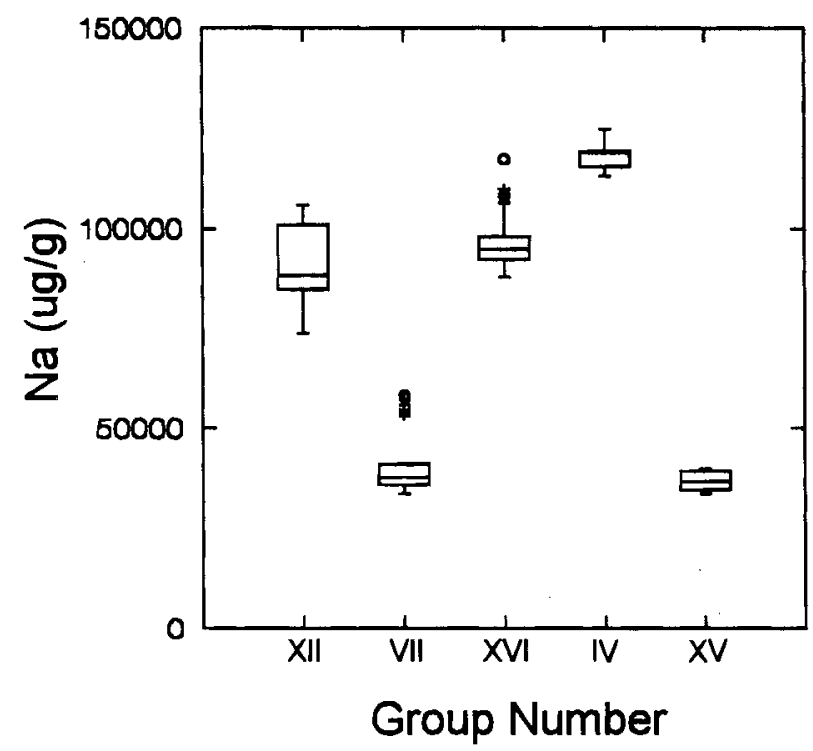

Figure 4.1. Box Plot of Sodium Concentration by SORWT Group

\subsubsection{Characteristics of Waste Types Included in SORWT Verification Study}

The five SORWT groups included in the verification study contain combinations of six different primary and secondary waste types (Table 4.1). These six different waste types are 224, 1C, 2C, TBP, $5-6$, and $R$. The identifying characteristics of these six wastes are described below. These descriptions are based on Anderson (1990), Schneider (1951), discussions with senior technical staff, and information found in Appendix B of this document, which also provides a nominal composition for most major waste types.

\subsubsection{Characteristics of 224 Waste}

224 waste is from the final decontamination and concentration stage of the $\mathrm{BiPO}_{4}$ process. Plutonium was decontaminated by oxidizing it with potassium permanganate and precipitating the byproducts with lanthanum fluoride. The decontaminated Pu-bearing solution was then reduced with ferrous ammonium sulfate, and the final product was precipitated with lanthanum fluoride. Lanthanum is the key indicator of 224 waste because this was the only stage at which La was introduced to the Hanford waste tanks. Manganese is a good analyte to differentiate from other $\mathrm{BiPO}_{4}$ waste because permanganates were used as oxidizing agents only during the final decontamination and concentration stage.

224 waste will also contain appreciable amounts of $\mathrm{Bi}, \mathrm{Cr}, \mathrm{Fe}$, and $\mathrm{PO}_{4}$ from additions to the product stream in earlier $\mathrm{BiPO}_{4}$ stages. These four analytes are characteristic of all $\mathrm{BiPO}_{4}$ wastes. 
Bismuth was added as both sodium bismuthate (strong oxidizer) and bismuth phosphate (precipitation agent). Iron was added in the form of ferrous ammonium sulfamate as a Pu reducing agent. Chromium was added in the form of sodium dichromate as a stabilizing oxidizer for the stronger sodium bismuthate. Although greater concentrations of fluoride ions in 224 waste would be expected relative to other $\mathrm{BiPO}_{4}$ wastes because of the lanthanum fluoride precipitations, there are also appreciable amounts of fluoride ions in $1 \mathrm{C}$ and $2 \mathrm{C}$ wastes. Less $\mathrm{U}$ would be expected in 224 waste than earlier decontamination cycle wastes because the $U$ is generally removed in the earlier stages of the process. According to the nominal compositions found in Appendix $\mathrm{B}$, an order of magnitude lower concentration of $\mathrm{PO}_{4}$ in 224 waste relative to other $\mathrm{BiPO}_{4}$ wastes might be expected.

\subsubsection{Characteristics of $1 \mathrm{C}$ Waste}

1C waste is the aqueous solution remaining after the first product decontamination cycle of the $\mathrm{BiPO}_{4}$ process. Nearly all of the $\mathrm{U}$ and $90 \%$ of the fission products were previously removed from the stream as metal waste. $1 \mathrm{C}$ wastes contained $10 \%$ of the fission products and $1 \%$ of the $\mathrm{Pu}$ (Anderson 1990). This waste type contains appreciable amounts of $\mathrm{Bi}, \mathrm{Cr}, \mathrm{Fe}$, and $\mathrm{PO}_{4}$ added as process chemicals for reasons detailed above. Cladding waste generated from the removal of aluminum cladding from the fuel slugs was added in many cases to the $1 \mathrm{C}$ waste and comprised approximately $24 \%$ of the waste stream. Thus, there may be instances where the model misclassifies a tank or number of tanks with $1 \mathrm{C}$ waste, depending on if $\mathrm{CW}$ was commingled and this fact was not well documented. The aluminum cladding was dissolved in a solution of sodium nitrate/sodium hydroxide. Therefore, much greater concentrations of $\mathrm{Al}, \mathrm{Na}$, and $\mathrm{NO}_{3}$ relative to other $\mathrm{BiPO}_{4}$ wastes would be expected in comparison with $1 \mathrm{C} / \mathrm{CW}$ effluent streams. The $\mathrm{CW}$ was intended to contain few fission products; $\mathrm{La}$ and $\mathrm{Mn}$ would not be expected to be found in $1 \mathrm{C}$ waste.

\subsubsection{Characteristics of 2C Waste}

$2 \mathrm{C}$ waste is the aqueous solution remaining after a second decontamination of the product cake from the first decontamination in the $\mathrm{BiPO}_{4}$ process. $2 \mathrm{C}$ waste should have similar characteristics as $1 \mathrm{C}$ waste but with fewer fission products. This waste type contains appreciable amounts of $\mathrm{Bi}, \mathrm{Cr}, \mathrm{Fe}$, and $\mathrm{PO}_{4}$ added as process chemicals for reasons detailed for 224 waste. Anderson (1990) claims that $2 \mathrm{C}$ waste contains only $0.1 \%$ of the fission products and $1 \%$ of the $\mathrm{Pu}$. This is consistent with the notion that most of the fission products would have been removed from the product stream in the previous decontamination cycle. $2 \mathrm{C}$ waste did NOT have $\mathrm{CW}$ added to the waste stream, so there should be a noticeable decrease in the $\mathrm{Al}, \mathrm{Na}$, and $\mathrm{NO}_{3}$ concentrations relative to $1 \mathrm{C}$ wastes; $\mathrm{La}$ and $\mathrm{Mn}$ would not be expected to be found in $2 \mathrm{C}$ waste.

\subsubsection{Characteristics of TBP Waste}

Tributyl phosphate waste was generated as a result of the extraction process at $U$ Plant to recover uranium metal from the metal waste produced in the $\mathrm{BiPO}_{4}$ process. This waste was composed of 
concentrated, neutralized aqueous effluents from the primary extraction column and from the solvent wash. TBP waste should contain very little $\mathrm{Pu}$ and a larger concentration of $\mathrm{U}$ relative to other $\mathrm{BiPO}_{4}$ wastes; La and Mn would not be expected to be found in TBP waste.

\subsubsection{Characteristics of 5-6 Waste}

In Appendix B, 5-6 is described as a very hot waste that collected in the bottom of Section 5 at $\mathrm{B}$ Plant as a result of boilover during dissolving and neutralization during the $\mathrm{BiPO}_{4}$ process. This is not a very detailed description; however, "a very hot waste" can be assumed to mean a relatively large concentration of fission products. Also, this waste would have a relatively large concentration of $\mathrm{Na}$ and $\mathrm{NO}_{3}$ from the dissolution in $\mathrm{HNO}_{3}$ and neutralization with $\mathrm{NaOH}$.

Further research has revealed that this waste could also be dilute $\mathrm{MW}$, dilute $1 \mathrm{C}$ waste, or water from canyon deck flushes or cooling/heating coil leakage. According to the Bismuth Phosphate manual, the 5-6 waste was to be sent to the concrete 361 tank and overflow to ground like the 224 waste if it was low in radioactivity; or sent to the $1 \mathrm{C}$ cascade if it was high in radioactivity, according to George Borsheim, WHC. The highly variable composition of 5-6 waste raises some doubt on whether 5-6 should be considered a characteristic waste.

\subsubsection{Characteristics of $\mathbf{R}$ Waste}

$\mathrm{R}$ waste is the high-level fraction of the process waste generated in the REDOX process. The REDOX process was a fundamentally different process from the $\mathrm{BiPO}_{4}$ process and generated characteristically different wastes. REDOX was an organic solvent extraction based process. REDOX was more efficient than $\mathrm{BiPO}_{4}$ and generated high-level wastes that were much more concentrated in fission products. In fact, the concentrations of fission products were so great that $\mathrm{R}$ waste often generated enough heat to self-boil. The reduction and oxidation of the product $\mathrm{Pu}$ was generally carried out in the smaller volume organic phase and required fewer process chemicals.

One characteristic expected in $\mathrm{R}$ waste would be high $\mathrm{Al}$ concentrations from a compound commonly known as ANN (aluminum nitrate nono hydrate) although likely not as high as $\mathrm{CW}$. This compound was added to $\mathrm{Pu}$ and $\mathrm{U}$ bearing solutions as a salting agent, enabling $\mathrm{Pu}$ to be extracted into the organic phase (hexone). Other characteristics expected of $\mathrm{R}$ waste would be the presence of $\mathrm{Cr}$ and Fe added as oxidizing (dichromates) and reducing agents (ferrous ammonium sulfamate), respectively.

A significantly lower concentration of $\mathrm{Fe}$ relative to the $\mathrm{BiPO}_{4}$ wastes would be expected because the reduction of $\mathrm{Pu}$ was conducted in a much smaller volume organic phase in the REDOX process and required smaller amounts of ferrous ammonium sulfamate. Another contrast with $\mathrm{BiPO}_{4}$ wastes would be the absence of $\mathrm{Bi}$ and $\mathrm{La}$ and a drastically smaller concentration of $\mathrm{PO}_{4}$. A higher concentration of $\mathrm{NO}_{3}$, relative to most $\mathrm{BiPO}_{4}$ wastes, would also be expected. 


\subsection{Analysis of Variance Results}

The ANOVA performed for each analyte included in the SORWT model verification study used the general linear model of the SYSTAT for Windows ${ }^{(a)}$ statistical data analysis software package. If a significant grouping effect was observed, then a Tukey pairwise comparison was also conducted for each analyte to investigate which groups were significantly different from the others. The output reports generated by the statistical software for each analyte are presented in Appendix E. Each page of Appendix E represents the analysis of a different analyte; the top portion of each page displays the ANOVA table.

The ANOVA table provides two estimates for the variance, one between groups and one within groups. If the null hypothesis (i.e., no differences between SORWT groups) is accurate, then the estimate for the between-group variance should be similar in magnitude to the within-group estimate of the variance. Conversely, if the between-group estimate of the variance is significantly greater than the within-group estimate, then the null hypothesis would be untenable, and some of the between-group variation must be caused by real differences between treatment groups.

The F-Ratio is defined as the ratio of the between-treatment variance (mean sum of the squares) and the within-treatment variance. (This value is also reported in the ANOVA table.) This ratio should follow an $\mathrm{F}$ distribution for the appropriate numbers of degrees of freedom. The significance of the F-Ratio is called a P-value and can be determined from the relevant F distribution. The significance is the fractional probability of the F-Test ratio happening only by random chance. The benchmark probabilities typically used to test the significance of differences between means is $5 \%$ and $1 \%$, which correspond to significances of 0.05 and 0.01 . For the purposes of the SORWT model verification study, the $5 \%$ benchmark was selected. If the significance is greater than the benchmarks, then the differences between treatment means can be explained by random chance. If the significances are below the benchmarks, then the discrepancies between treatment means cannot be explained by random chance, and real differences exist between the subject groups. The P-Value for each analyte is included in the ANOVA table.

A summary of the ANOVA results for each of the analytes tested is presented in Table 4.4. As shown in Table 4.4, all 22 analytes and measurements listed have a significance well below the benchmark $5 \%$ level. In fact, all but two analytes have a significance below $0.1 \%$. Table 4.4 indicates there is virtually no probability that the differences between the means of the SORWT groups are due only to random chance. Therefore, the null hypothesis is invalid, and the data strongly support the premise that SORWT groups exist.

Since a significant grouping effect was observed, a Tukey pairwise comparison was performed to identify which groups were significantly different from one another. This comparison can be found on the bottom portion of each page in Appendix E. The Tukey pairwise comparison first generates a matrix of pairwise mean differences. These are the differences between the mean concentrations of a

(a) SYSTAT for Windows is a registered trademark of SYSTAT, Inc. 
Table 4.4. Summary of ANOVA for SORWT Verification Study

\begin{tabular}{|c|c|c|c|c|c|c|c|}
\hline Analyte & $\begin{array}{c}\text { F-Test } \\
\text { Ratio }\end{array}$ & $\begin{array}{c}\text { Significanc } \\
\text { e } \\
\text { (P-value) }\end{array}$ & $\begin{array}{c}\text { Group } \\
\text { VII } \\
\text { Mean } \\
(\mu \mathrm{g} / \mathrm{g})\end{array}$ & $\begin{array}{c}\text { Group } \\
\text { IV } \\
\text { Mean } \\
(\mu g / g)\end{array}$ & $\begin{array}{c}\text { Group } \\
\text { XII } \\
\text { Mean } \\
\text { ( } \mu \mathrm{g} / \mathrm{g})\end{array}$ & $\begin{array}{c}\text { Group } \\
\text { XV } \\
\text { Mean } \\
(\mu g / g)\end{array}$ & $\begin{array}{c}\text { Group } \\
\text { XVI } \\
\text { Mean } \\
(\mu \mathrm{g} / \mathrm{g})\end{array}$ \\
\hline $\mathrm{Al}$ & $5,514.85$ & 0.000 & 3,490 & 117,000 & 14,323 & 570 & 1,425 \\
\hline $\mathrm{Bi}$ & 45.15 & 0.000 & 61,753 & 39 & 17,356 & 23,563 & 19,354 \\
\hline $\mathrm{Cr}$ & 199.78 & 0.000 & 2,835 & 2,353 & 685 & 1,799 & 854 \\
\hline $\mathrm{Fe}$ & 75.35 & 0.000 & 10,156 & 1,424 & 10,812 & 18,038 & 17,486 \\
\hline $\mathrm{La}$ & $2,284.41$ & 0.000 & 13,592 & 9 & 8 & 4,108 & 74 \\
\hline $\mathrm{Mn}$ & 64.67 & 0.000 & 14,508 & 1,150 & 58 & 6,283 & 97 \\
\hline $\mathrm{Na}$ & 385.20 & 0.000 & 41,364 & 118,250 & 91,133 & 36,950 & 96,359 \\
\hline $\mathrm{Pb}$ & 15.11 & 0.000 & 1,125 & 39 & 181 & 365 & 750 \\
\hline $\mathrm{Si}$ & 5.58 & 0.000 & 15,648 & 1,326 & 6,933 & 5,565 & 10,173 \\
\hline $\mathrm{Zr}$ & 3.76 & 0.007 & 29 & 21 & 153 & 4 & 134 \\
\hline $\mathrm{U}$ & 11.95 & 0.000 & 414 & 6,685 & 4,249 & 2,555 & 209 \\
\hline $\mathrm{PO}_{4}(\mathrm{aq})$ & 59.63 & 0.000 & 1,706 & 1,310 & 22,256 & 15,538 & 24,555 \\
\hline $\mathrm{NO}_{3}$ & 47.38 & 0.000 & 56,589 & 186,300 & 121,261 & 41,238 & 145,000 \\
\hline $\mathrm{NO}_{2}$ & 21.38 & 0.000 & 719 & 25,730 & 7,638 & 897 & 22,910 \\
\hline $\mathbf{F}$ & 206.39 & 0.000 & 6,134 & 132 & 8,261 & 2,301 & 1,761 \\
\hline $\mathrm{Cl}$ & 106.63 & 0.000 & 1,225 & 3,162 & 1,116 & 450 & 1,153 \\
\hline \multirow[t]{2}{*}{ TOC } & \multirow[t]{2}{*}{5.38} & \multirow[t]{2}{*}{0.001} & 8,768 & 1,606 & 739 & 3,119 & 634 \\
\hline & & & $(\mu \mathrm{Ci} / \mathrm{g})$ & $(\mu \mathrm{Ci} / \mathrm{g})$ & $(\mu \mathrm{Ci} / \mathrm{g})$ & $(\mu \mathrm{Ci} / \mathrm{g})$ & $(\mu \mathrm{Ci} / \mathrm{g})$ \\
\hline${ }^{137} \mathrm{Cs}$ & 7.34 & 0.000 & 0.403 & 62.308 & 18.533 & 0.166 & 40.638 \\
\hline${ }^{90} \mathrm{Sr}$ & 64.54 & 0.000 & 3.17 & 309.583 & 7.188 & 5.414 & 133.436 \\
\hline \multirow[t]{2}{*}{${ }^{239 / 240} \mathrm{Pu}$} & \multirow[t]{2}{*}{13.92} & \multirow[t]{2}{*}{0.000} & 0.606 & 0.282 & 0.07 & 0.139 & 0.107 \\
\hline & & & $(\mathrm{g} / \mathrm{ml})$ & $(\mathrm{g} / \mathrm{ml})$ & $(\mathrm{g} / \mathrm{ml})$ & $(\mathrm{g} / \mathrm{ml})$ & $(\mathrm{g} / \mathrm{ml})$ \\
\hline Density & 13.89 & 0.000 & 1.171 & 1.64 & 1.286 & 1.235 & 1.271 \\
\hline pH & 84.88 & 0.000 & NA & 12.803 & 10.631 & 11.65 & 8.221 \\
\hline
\end{tabular}

pair of groups. The routine then compares this difference to the mean square error for the analyte calculated from the ANOVA table and calculates a P-value (probability) that the difference between the mean concentrations of any two groups is due to random chance. These P-values are presented as the matrix at the bottom of each page in Appendix E.

Tables 4.5 and 4.6 present a summary of the Tukey pairwise comparisons. These tables respectively present the number of analytes that are significantly different between any pair of SORWT 
Table 4.5. Number of Analytes Showing Significant Difference Between Groups

\begin{tabular}{||c|c|c|c|c||}
\hline \hline Group No. & VII & IV & XII & XV \\
\hline IV & 18 & & & \\
\hline XII & 14 & 12 & & \\
\hline XV & 10 & 14 & 9 & \\
\hline XVI & 16 & 13 & 8 & 9 \\
\hline
\end{tabular}

Table 4.6. Analytes Showing Significant Concentration Difference Between Groups

\begin{tabular}{|c|c|c|c|c|}
\hline Group No. & VII & IV & XII & $\mathbf{X V}$ \\
\hline IV & $\begin{array}{l}\mathrm{Al}, \mathrm{Bi}, \mathrm{Cr}, \mathrm{Fe}, \mathrm{La}, \mathrm{Mn} \text {, } \\
\mathrm{Na}, \mathrm{Pb}, \mathrm{Si},{ }^{137} \mathrm{Cs},{ }^{90} \mathrm{Sr} \text {, } \\
{ }^{239 / 240} \mathrm{Pu}, \mathrm{U}, \mathrm{NO}_{3} \text {, } \\
\mathrm{NO}_{2}, \mathrm{~F}, \mathrm{Cl}, \mathrm{TOC}\end{array}$ & & & \\
\hline XII & $\begin{array}{l}\mathrm{Al}, \mathrm{Bi}, \mathrm{Cr}, \mathrm{La}, \mathrm{Mn}, \\
\mathrm{Na}, \mathrm{Pb}, \mathrm{Si},{ }^{239 / 240} \mathrm{Pu} \\
\mathrm{U}, \mathrm{PO}_{4}(\mathrm{aq}), \mathrm{NO}_{3}, \mathrm{~F}, \\
\text { TOC }\end{array}$ & $\begin{array}{l}\mathrm{Al}, \mathrm{Bi}, \mathrm{Cr}, \mathrm{Fe}, \mathrm{Na}, \\
{ }^{137} \mathrm{Cs},{ }^{90} \mathrm{Sr}, \mathrm{PO}_{4}(\mathrm{aq}), \\
\mathrm{NO}_{3}, \mathrm{NO}_{2}, \mathrm{~F}, \mathrm{Cl}\end{array}$ & & \\
\hline$X V$ & $\begin{array}{l}\mathrm{Bi}, \mathrm{Cr}, \mathrm{Fe}, \mathrm{La}, \mathrm{Mn}, \mathrm{Pb} \text {, } \\
239 / 240 \mathrm{Pu}, \mathrm{PO}_{4}(\mathrm{aq}), \mathrm{F}, \\
\mathrm{Cl}\end{array}$ & $\begin{array}{l}\mathrm{Al}, \mathrm{Bi}, \mathrm{Cr}, \mathrm{Fe}, \mathrm{La}, \mathrm{Mn} \text {, } \\
\mathrm{Na},{ }^{137} \mathrm{Cs},{ }^{90} \mathrm{Sr}, \mathrm{PO}_{4} \\
\text { (aq), } \mathrm{NO}_{3}, \mathrm{NO}_{2}, \mathrm{~F}, \mathrm{Cl}\end{array}$ & $\begin{array}{l}\mathrm{Al}, \mathrm{Cr}, \mathrm{Fe}, \mathrm{La}, \\
\mathrm{Mn}, \mathrm{Na}, \mathrm{NO}_{3}, \mathrm{~F}, \\
\mathrm{Cl}\end{array}$ & \\
\hline XVI & $\begin{array}{l}\mathrm{Al}, \mathrm{Bi}, \mathrm{Cr}, \mathrm{Fe}, \mathrm{La}, \mathrm{Mn} \text {, } \\
\mathrm{Na}, \mathrm{Pb},{ }^{137} \mathrm{Cs}, \\
239 / 240 \mathrm{Pu}, \mathrm{PO}_{4}(\mathrm{aq}) \\
\mathrm{NO}_{3}, \mathrm{NO}_{2}, \mathrm{~F}, \mathrm{TOC} \\
{ }^{90} \mathrm{Sr}\end{array}$ & $\begin{array}{l}\mathrm{Al}, \mathrm{Bi}, \mathrm{Cr}, \mathrm{Fe}, \mathrm{Na}, \mathrm{Pb} \\
\mathrm{Si},{ }^{90} \mathrm{Sr}, \mathrm{U}, \mathrm{PO}_{4}(\mathrm{aq}) \\
\mathrm{NO}_{3}, \mathrm{~F}, \mathrm{Cl}\end{array}$ & $\begin{array}{l}\mathrm{Al}, \mathrm{Fe}, \mathrm{Na}, \mathrm{Pb}, \\
{ }^{90} \mathrm{Sr}, \mathrm{U}, \mathrm{NO}_{2}, \mathrm{~F}\end{array}$ & $\begin{array}{l}\mathrm{Cr}, \mathrm{La}, \mathrm{Mn}, \mathrm{Na}, \\
{ }^{90} \mathrm{Sr}, \mathrm{PO}_{4}(\mathrm{aq}), \\
\mathrm{NO}_{3}, \mathrm{NO}_{2}, \mathrm{Cl}\end{array}$ \\
\hline
\end{tabular}

groups and a listing of which analytes differ significantly in the pair. As shown in Table 4.5, 18 out of 20 analytes were significantly different between Group VII and Group IV. The smallest number of analytes that were significantly different between groups was eight analytes when comparing Group XVI to Group XII. More than half the analytes considered in this study were significantly different for 7 of the 10 pairwise comparisons. This is another strong indication that the grouping methodology utilized by the SORWT model predicts real differences between the characteristics of tank groups.

Density and $\mathrm{pH}$ were not included in these Tukey summary tables. 


\subsection{Descriptive Statistics of SORWT Group Data}

In addition to the ANOVA study, descriptive statistics were calculated for each analyte by SORWT group. The descriptive statistics routine provides useful information such as number of cases, maximum and minimum values, range of values, mean values, standard deviations, variance, and coefficient of variance $(\mathrm{CV})$. The report outputs from this routine for each group and analyte are included as Appendix F.

A comparison between the ungrouped composite results and the SORWT group results is summarized in Table 4.7. This table presents the analyte mean value and the CV for the ungrouped data and

Table 4.7. Nominal Compositions of Five SORWT Groups

\begin{tabular}{|c|c|c|c|c|c|c|c|c|c|c|c|c|}
\hline Analyto & $\begin{array}{l}\text { Group } \\
\text { VII } \\
\text { Mean } \\
(\mu g / g)\end{array}$ & c.v. & $\begin{array}{l}\text { Group } \\
\text { IV } \\
\text { Mean } \\
(m g / g)\end{array}$ & C.v. & $\begin{array}{l}\text { Group } \\
\text { XII } \\
\text { Mean } \\
(\mu g / g)\end{array}$ & c.v. & $\begin{array}{c}\text { Group } \\
\text { XV } \\
\text { Mean } \\
(\mu g / g)\end{array}$ & C.V. & $\begin{array}{c}\text { Group } \\
\text { XVI } \\
\text { Mean } \\
(\mu g / g)\end{array}$ & C.V. & $\begin{array}{c}\text { Overall } \\
\text { Mean } \\
(\mu g / g)\end{array}$ & c.v. \\
\hline Al & 3,490 & 1.35 & 117,000 & 0.034 & 14,323 & 0.099 & 570 & 0.189 & 1,425 & 0.692 & 17,418 & 2.11 \\
\hline$\overline{\mathrm{Bi}}$ & 61,753 & 0.528 & 38.8 & 0.192 & 17,356 & 0.305 & 23,562 & 0.138 & 19,354 & 0.127 & 24,079 & 0.927 \\
\hline $\mathrm{Cr}$ & 2,835 & 0.22 & 2,353 & 0.062 & 685 & 0.393 & 1,799 & 0.043 & 854 & 0.163 & 1,399 & 0.63 \\
\hline $\mathrm{Fe}$ & 10,156 & 0.487 & 1,424 & 0.469 & 10,812 & 0.13 & 18,038 & 0.121 & 17,486 & 0.188 & 13,281 & 0.469 \\
\hline La & 13,592 & 0.092 & 9.41 & 0.117 & 7.97 & 0.004 & 4,108 & 0.15 & 73.6 & 0.302 & 2,599 & 1.94 \\
\hline$M n$ & 14,508 & 0.574 & 1,150 & 0.336 & 58.1 & 0.298 & 6,282 & 0.042 & 97.2 & 0.26 & 3,072 & 2.05 \\
\hline $\mathrm{Na}$ & 41,364 & 0.206 & 118,250 & 0.031 & 91,133 & 0.105 & 36,950 & 0.073 & 96,359 & 0.061 & 84,305 & 0.323 \\
\hline $\mathrm{Pb}$ & 1,125 & 0.574 & 38.6 & 0.076 & 181 & 0.828 & 365 & 0.288 & 750 & 0.732 & 600 & 0.969 \\
\hline $\mathrm{Si}$ & 15,648 & 1.34 & 1,326 & 0.282 & 6,933 & 0.105 & 5,565 & 0.056 & 10,173 & 0.264 & 9,122 & 1.04 \\
\hline $\mathrm{Zr}$ & 28.9 & 0.959 & 21.2 & 0.463 & 153 & 0.295 & 4 & 0.002 & 134 & 1.6 & 96.6 & 1.63 \\
\hline $\mathbf{U}$ & 414 & 0.561 & 6,685 & 0.103 & 4,249 & 1.7 & 2,555 & 0.481 & 209 & 0.164 & 2,130 & 1.87 \\
\hline $\mathrm{PO}_{4}(\mathrm{aq})$ & 1,706 & 0.289 & 1,310 & 0.352 & 22,256 & 0.523 & 15,538 & 0.1 & 24,555 & 0.067 & 14,591 & 0.806 \\
\hline $\mathrm{NO}_{3}$ & 56,589 & 0.131 & 186,300 & 0.076 & 121,261 & 0.15 & 41,238 & 0.079 & 145,000 & 0.361 & 112,950 & 0.503 \\
\hline $\mathrm{NO}_{2}$ & 719 & 0.286 & 25,730 & 0.122 & 7,638 & 0.602 & 897 & 0.198 & 22,910 & 0.756 & 12,091 & 1.16 \\
\hline $\mathbf{F}$ & 6,134 & 0.073 & 132 & 0.346 & 8,261 & 0.206 & 2,301 & 0.377 & 1,761 & 0.147 & 4,179 & 0.756 \\
\hline $\mathrm{Cl}$ & 1,225 & 0.38 & 3,162 & 0.05 & 1,116 & 0.332 & 450 & 0.102 & 1,153 & 0.152 & 1,351 & 0.594 \\
\hline \multirow[t]{2}{*}{ TOC } & 8,768 & 1.42 & 1,606 & 0.35 & 739 & 0.323 & 3,119 & 0.255 & 634 & 0.675 & 2,416 & 2.31 \\
\hline & $(\mu \mathrm{Ci} / \mathbf{g})$ & & $(\mu \mathrm{Ci} / \mathbf{g})$ & & $(\mu \mathrm{Ci} / \mathrm{g})$ & & $(\mu \mathrm{Ci} / \mathrm{g})$ & & $(\mu \mathrm{Ci} / \mathbf{g})$ & & $(\mu \mathrm{Ci} / \mathbf{g})$ & \\
\hline${ }^{137} \mathrm{Cs}$ & 0.403 & 1.11 & 62.3 & 0.053 & 18.5 & 0.263 & 0.166 & 0.377 & 40.6 & 1.39 & 28.8 & 1.48 \\
\hline${ }^{80} \mathrm{Sr}$ & 3.17 & 0.595 & 310 & 0.081 & 7.19 & 0.409 & 5.414 & 0.372 & 133 & 0.751 & 92.4 & 1.31 \\
\hline \multirow[t]{2}{*}{${ }^{298200} \mathrm{Pu}$} & 0.606 & 0.897 & 0.282 & 0.373 & 0.07 & 0.432 & 0.139 & 0.051 & 0.107 & 0.185 & 0.231 & 1.39 \\
\hline & $(\mathrm{g} / \mathrm{ml})$ & & $(\mathrm{g} / \mathrm{ml})$ & & $(\mathrm{g} / \mathrm{ml})$ & & $(\mathrm{g} / \mathrm{ml})$ & & $(g / m b)$ & & $(\mathrm{g} / \mathrm{ml})$ & \\
\hline Density & 1.171 & 0.114 & 1.64 & 0 & 1.286 & 0.124 & 1.235 & 0.052 & 1.271 & 0.074 & 1.24 & 0.109 \\
\hline $\mathrm{pH}$ & NA & NA & 12.8 & 0.074 & 10.6 & 0.063 & 11.6 & 0 & 8.22 & 0.054 & 10.4 & 0.186 \\
\hline
\end{tabular}


each of the SORWT groups. The CV is defined as the standard deviation divided by the mean value. Since the CVs is normalized by its mean, all CVs are unitless and comparable to each other.

As shown in Table 4.7, there is a dramatic decrease in the CV for most analytes when the data have been categorized by SORWT group. This observation tends to strengthen the conclusion that the SORWT grouping methodology accurately identifies real distinctions between the waste characteristics of different groups.

\subsection{Pairwise Comparisons}

The analytical data from recent core samples collected from the waste tanks strongly support the validity of the SORWT model grouping methodology. Another qualitative observation that can be made from these data is to compare expected indicator analytes for the various waste types found in the tanks contained in the verification study with the analytical data from the same tanks. There will be certain differences in waste characteristics of the various SORWT groups that would be expected based upon the waste type. The expected differences can be confirmed or dismissed by the actual analytical data.

\subsubsection{Expected Compositional Differences Between SORWT Groups}

This section makes pairwise comparisons between SORWT groups and identifies expected differences in characteristics based upon the waste types making up a SORWT group. This effort is somewhat complicated, because three of the five SORWT groups included in the verification study have a primary and secondary waste type. Some qualitative interpretation is required to determine the influence the characteristics of each waste type has on the overall character of the group. It is important to note that very few SORWT groups, 4 out of 24 , have only a primary waste type.

First, the expected characteristics of each SORWT group are determined. These determinations are made in a semi-quantitative fashion such that the concentrations of 12 analytes are placed into one of several categories: very high, high, medium, low, and none. The definitions of these categories are provided in Table 4.8 .

The categories have slightly different definitions for radionuclides and nonradionuclides. The characteristics of each SORWT group included in the verification study were determined using the categories above and the descriptions of the each waste type from the previous section. Fission products are the sum of the ${ }^{137} \mathrm{Cs}$ and ${ }^{90} \mathrm{Sr}$ activity concentrations. The expected characteristics are summarized in Table 4.9. A pairwise order-of-magnitude comparison was then made between each SORWT group. These pairwise comparisons represent the expected differences between the analyte concentrations of the respective SORWT groups. The pairwise comparisons are also included in Table 4.9.

The comparisons listed in Table 4.9 are the expected concentration category of the row group relative to the expected concentration category of the column group. If the expected concentration 
Table 4.8. Concentration Categories for Expected Characteristics

\begin{tabular}{|c|c|}
\hline Nonradionuclides $(\mu \mathrm{g} / \mathrm{g})$ & Radionuclides $(\mu \mathrm{Ci} / \mathrm{g})$ \\
\hline $100,000<$ Very High & $100<$ High \\
$10,000<$ High $<100,000$ & $10<$ Medium $<100$ \\
$1,000<$ Medium $<10,000$ & Low $<10$ \\
$100<$ Low $<1,000$ & \\
None $<100$ & \\
\hline
\end{tabular}

Table 4.9. Pairwise Comparison of Expected Characteristics

\begin{tabular}{|c|c|c|c|c|c|c|c|}
\hline \multirow[b]{2}{*}{$\begin{array}{c}\text { SORWT } \\
\text { Group }\end{array}$} & \multirow{2}{*}{$\begin{array}{c}\text { Characteristic } \\
\text { Summary of SORWT } \\
\text { Group }\end{array}$} & \multirow[b]{2}{*}{$\begin{array}{c}\text { Comparison } \\
\text { Analytes }\end{array}$} & \multicolumn{5}{|c|}{ Pairwise Comparison Group } \\
\hline & & & $\begin{array}{c}\text { Group } \\
\text { VII }\end{array}$ & $\begin{array}{c}\text { Group } \\
\text { IV }\end{array}$ & $\begin{array}{c}\text { Group } \\
\text { XII }\end{array}$ & $\begin{array}{c}\text { Group } \\
\text { XV }\end{array}$ & $\begin{array}{c}\text { Group } \\
\text { XVI }\end{array}$ \\
\hline $\begin{array}{l}\text { VII } \\
224\end{array}$ & $\begin{array}{l}\text { High } \mathrm{Na} \\
\mathrm{High} \mathrm{NO}_{3} \\
\mathrm{High} \mathrm{La} \\
\mathrm{High} \mathrm{Mn} \\
\mathrm{High} \mathrm{Bi} \\
\mathrm{High} \mathrm{Fe} \\
\text { Medium } \mathrm{PO}_{4} \\
\text { Medium } \mathrm{Cr} \\
\text { Medium F } \\
\text { Low Al } \\
\text { Low U } \\
\text { Low Fission Products }\end{array}$ & \begin{tabular}{|l|}
$\mathrm{Al}$ \\
$\mathrm{Bi}$ \\
$\mathrm{Cr}$ \\
$\mathrm{Fe}$ \\
$\mathrm{La}$ \\
$\mathrm{Mn}$ \\
$\mathrm{Na}$ \\
$\mathrm{U}$ \\
$\mathrm{NO}_{3}$ \\
$\mathrm{PO}_{4}$ (aq) \\
$\mathrm{F}$ \\
Fission Products
\end{tabular} & & $\begin{array}{c}- \\
+++ \\
0 \\
+ \\
+++ \\
? \\
- \\
- \\
- \\
+ \\
? \\
-\end{array}$ & $\begin{array}{c}-- \\
0 \\
0 \\
0 \\
+++ \\
+++ \\
- \\
- \\
- \\
- \\
0 \\
-\end{array}$ & $\begin{array}{l}0 \\
0 \\
0 \\
0 \\
+ \\
+ \\
0 \\
0 \\
0 \\
- \\
0 \\
0\end{array}$ & $\begin{array}{c}0 \\
0 \\
0 \\
0 \\
+++ \\
+++ \\
- \\
0 \\
- \\
- \\
0 \\
-\end{array}$ \\
\hline $\begin{array}{c}\Gamma \mathrm{V} \\
\mathrm{R}\end{array}$ & $\begin{array}{l}\text { Very High } \mathrm{NO}_{3} \\
\text { Very High Na } \\
\text { High Al } \\
\text { High Fission Products } \\
\text { Medium Iron } \\
\text { Medium Cr } \\
\text { Medium U } \\
{\text { Low } \mathrm{PO}_{4}} \\
\text { No Bi } \\
\text { No La }\end{array}$ & \begin{tabular}{|l|}
$\mathrm{Al}$ \\
$\mathrm{Bi}$ \\
$\mathrm{Cr}$ \\
$\mathrm{Fe}$ \\
$\mathrm{La}$ \\
$\mathrm{Mn}$ \\
$\mathrm{Na}$ \\
$\mathrm{U}$ \\
$\mathrm{NO}_{3}$ \\
$\mathrm{PO}_{4}$ (aq) \\
$\mathrm{F}$ \\
Fission Products
\end{tabular} & $\begin{array}{c}+ \\
-- \\
0 \\
- \\
-- \\
? \\
+ \\
+ \\
+ \\
- \\
? \\
++\end{array}$ & & $\begin{array}{l}0 \\
--- \\
0 \\
- \\
0 \\
? \\
0 \\
0 \\
0 \\
-- \\
? \\
+\end{array}$ & $\begin{array}{c}++ \\
--- \\
0 \\
- \\
-- \\
? \\
+ \\
+ \\
+ \\
- \\
? \\
++\end{array}$ & $\begin{array}{c}++ \\
-- \\
0 \\
- \\
0 \\
? \\
0 \\
+ \\
0 \\
-- \\
? \\
0\end{array}$ \\
\hline
\end{tabular}


Table 4.9. (contd)

\begin{tabular}{|c|c|c|c|c|c|c|c|}
\hline \multirow[b]{2}{*}{$\begin{array}{c}\text { SORWT } \\
\text { Group }\end{array}$} & \multirow{2}{*}{$\begin{array}{c}\text { Characteristic } \\
\text { Summary of SORWT } \\
\text { Group }\end{array}$} & \multirow[b]{2}{*}{$\begin{array}{c}\text { Comparison } \\
\text { Analytes }\end{array}$} & \multicolumn{5}{|c|}{ Pairwise Comparison Group } \\
\hline & & & $\begin{array}{c}\text { Group } \\
\text { VII }\end{array}$ & $\begin{array}{c}\text { Group } \\
\text { IV }\end{array}$ & $\begin{array}{l}\text { Group } \\
\text { XII }\end{array}$ & $\begin{array}{l}\text { Group } \\
\text { XV }\end{array}$ & $\begin{array}{l}\text { Group } \\
\text { XVI }\end{array}$ \\
\hline \multirow{12}{*}{$\begin{array}{c}\text { XII } \\
\text { IC TBP }\end{array}$} & Very High Na & AI & ++ & 0 & & ++ & ++ \\
\hline & Very High $\mathrm{NO}_{3}$ & $\mathrm{Bi}$ & 0 & +++ & & 0 & 0 \\
\hline & High Al & $\mathrm{Cr}$ & 0 & 0 & & 0 & 0 \\
\hline & High Bi & $\mathrm{Fe}$ & 0 & + & & 0 & 0 \\
\hline & High $\mathrm{PO}_{4}$ & $\mathrm{La}$ & -- & 0 & & -- & 0 \\
\hline & High Fe & Mn & --- & ? & & -- & 0 \\
\hline & Medium U & $\mathrm{Na}$ & + & 0 & & + & 0 \\
\hline & Medium Fission Products & $\mathrm{U}$ & + & 0 & & + & + \\
\hline & Medium $\mathrm{Cr}$ & $\mathrm{NO}_{3}$ & + & 0 & & + & 0 \\
\hline & Medium F & $\mathrm{PO}_{4}(\mathrm{aq})$ & + & ++ & & 0 & 0 \\
\hline & No La & $\mathrm{F}$ & 0 & ? & & 0 & 0 \\
\hline & No $\mathrm{Mn}$ & Fission Products & + & - & & + & - \\
\hline \multirow{12}{*}{$\begin{array}{c}X V \\
2 C 224\end{array}$} & High Na & $\overline{\mathrm{Al}}$ & 0 & -- & -- & & $\overline{0}$ \\
\hline & $\mathrm{High} \mathrm{NO}_{3}$ & $\mathrm{Bi}$ & 0 & $+t+$ & 0 & & 0 \\
\hline & High $\mathrm{Bi}$ & $\mathrm{Cr}$ & 0 & 0 & 0 & & 0 \\
\hline & High $\mathrm{PO}_{4}$ & $\mathrm{Fe}$ & 0 & + & 0 & & 0 \\
\hline & High Fe & $\mathrm{La}$ & - & ++ & $+t$ & & ++ \\
\hline & Medium F & $\mathrm{Mn}$ & - & ? & $+t$ & & ++ \\
\hline & Medium La & $\mathrm{Na}$ & 0 & - & - & & - \\
\hline & Medium Mn & $\mathrm{U}$ & 0 & - & - & & 0 \\
\hline & Medium $\mathrm{Cr}$ & $\mathrm{NO}_{3}$ & 0 & - & - & & - \\
\hline & Low Al & $\mathrm{PO}_{4}(\mathrm{aq})$ & + & ++ & 0 & & 0 \\
\hline & Low U & $\mathrm{F}$ & 0 & ? & 0 & & 0 \\
\hline & Low Fission Products & Fission Products & 0 & -- & - & \% & -- \\
\hline \multirow{12}{*}{$\begin{array}{c}\text { XVI } \\
2 \mathrm{C} 5-6\end{array}$} & Very High Na & $\overline{\mathrm{Al}}$ & 0 & -- & - & 0 & \\
\hline & Very High $\mathrm{NO}_{3}$ & $\mathrm{Bi}$ & 0 & +++ & 0 & 0 & \\
\hline & High $\mathrm{Bi}$ & $\mathrm{Cr}$ & 0 & 0 & 0 & 0 & \\
\hline & High $\mathrm{PO}_{4}$ & $\mathrm{Fe}$ & 0 & + & 0 & 0 & \\
\hline & High Fe & La & -- & 0 & 0 & -- & \\
\hline & High Fission Products & Mn & -- & ? & 0 & -- & \\
\hline & Medium F & $\mathrm{Na}$ & + & 0 & 0 & + & \\
\hline & Medium Cr & $\mathrm{U}$ & 0 & - & - & 0 & \\
\hline & Low Al & $\mathrm{NO}_{3}$ & + & 0 & 0 & + & \\
\hline & Low U & $\mathrm{PO}_{4}(\mathrm{aq})$ & + & ++ & 0 & 0 & \\
\hline & No La & $\mathrm{F}$ & 0 & ? & 0 & 0 & \\
\hline & No $\mathrm{Mn}$ & Fission Products & ++ & 0 & + & ++ & \\
\hline
\end{tabular}

category of the row group is an order of magnitude lower than the expected concentration group of the column, a "-" was placed in Table 4.9. If the concentration category difference was two orders of magnitude lower, then "--" was placed in the table. If the expected concentration of the row group was greater than the expected concentration of the column group, then a " + "was entered into the table.

The number of symbols represents the number of orders of magnitude difference that would be expected between the concentrations of the respective groups. If there was no expected order of 
magnitude difference between the groups, a " 0 " was entered in the table. The "?" designates a comparison that could not be made due to lack of information. The pairwise comparison was made for each of the analytes listed in Table 4.9 .

An example of determining the expected difference between two SORWT groups is the comparison of Bi between row Group VII and column Group IV. The Bi concentration of the row group is expected to be "high," whereas the expected concentration of $\mathrm{Bi}$ in the column group is expected to be "none." Therefore, the concentration of $\mathrm{Bi}$ in Group VII is expected to be three orders of magnitude greater than Group IV and would be notated in Table 4.9 as " +++ ."

\subsubsection{Comparison of Observed and Expected Differences Between Different SORWT Groups}

A similar exercise was accomplished for the observed characteristic differences between SORWT groups. First, the observed characteristics of the SORWT groups were determined using the concentration categories in Table 4.8 and the nominal compositions of the SORWT groups from Table 4.7.

The observed characteristics of the SORWT groups are summarized in Table 4.10. The pairwise comparison was then repeated for the observed characteristics using the same notation scheme, and the results are also presented in Table 4.10 .

The observed group characteristics and pairwise comparison were then compared with the expected characteristics, and the results are summarized in Table 4.11. The majority of the observed characteristics matched the corresponding expected characteristics. Table 4.11 presents the ratio of number of analytes in agreement to the total number of analytes compared. This comparison was made for the group characteristics and each of the pairwise comparisons.

There is a minimum agreement between the observed and expected characteristics of 8 out of 10 analytes compared for Group IV and a maximum agreement of 11 out of 12 for Groups VII, XII, and $\mathrm{XV}$. In fact, there was almost a 12-for-12 agreement with Group XII, except that the concentration of $\mathrm{Na}$ was just barely below the threshold $(91,133$ compared with 100,000$)$ of the concentration category expected. The high degree of agreement between the observed characteristics determined by laboratory analyses for each SORWT group and the expected characteristics based solely on the waste types is further evidence that the SORWT grouping methodology is accurately and effectively predicting real distinctions between groups of tanks. 
Table 4.10. Pairwise Comparison of Observed Characteristics

\begin{tabular}{|c|c|c|c|c|c|c|c|}
\hline \multirow{2}{*}{$\begin{array}{c}\text { SORWT } \\
\text { Group }\end{array}$} & \multirow{2}{*}{$\begin{array}{c}\text { Observed } \\
\text { Characteristics } \\
\text { of SORWT Group }\end{array}$} & \multirow{2}{*}{$\begin{array}{c}\text { Comparison } \\
\text { Analytes }\end{array}$} & \multicolumn{5}{|c|}{ Pairwise Comparison Group } \\
\hline & & & $\begin{array}{c}\text { Group } \\
\text { VII }\end{array}$ & $\begin{array}{c}\text { Group } \\
\text { IV }\end{array}$ & $\begin{array}{c}\text { Group } \\
\text { XII }\end{array}$ & $\begin{array}{c}\text { Group } \\
\text { XV }\end{array}$ & $\begin{array}{c}\text { Group } \\
\text { XVI }\end{array}$ \\
\hline $\begin{array}{l}\text { VII } \\
224\end{array}$ & $\begin{array}{l}\text { High Na } \\
\text { High } \mathrm{NO}_{3} \\
\mathrm{High} \mathrm{La} \\
\mathrm{High} \mathrm{Mn} \\
\mathrm{High} \mathrm{Bi} \\
\mathrm{High} \mathrm{Fe} \\
\text { Medium } \mathrm{PO}_{4} \\
\text { Medium Cr } \\
\text { Medium F } \\
\text { Medium Al } \\
\text { Low Fission Products } \\
\text { Low U }\end{array}$ & $\begin{array}{l}\mathrm{Al} \\
\mathrm{Bi} \\
\mathrm{Cr} \\
\mathrm{Fe} \\
\mathrm{La} \\
\mathrm{Mn} \\
\mathrm{Na} \\
\mathrm{U} \\
\mathrm{NO}_{3} \\
\mathrm{PO}_{4} \text { (aq) } \\
\mathrm{F} \\
\text { Fission Products }\end{array}$ & & $\begin{array}{c}-- \\
+++ \\
0 \\
+ \\
+++ \\
+ \\
- \\
- \\
- \\
0 \\
+ \\
+-\end{array}$ & $\begin{array}{c}0 \\
0 \\
0 \\
+++ \\
+++ \\
0 \\
- \\
- \\
- \\
0 \\
-\end{array}$ & $\begin{array}{l}+ \\
0 \\
0 \\
0 \\
+ \\
+ \\
0 \\
- \\
0 \\
- \\
0 \\
0\end{array}$ & $\begin{array}{c}0 \\
0 \\
0 \\
0 \\
+++ \\
+++ \\
0 \\
0 \\
- \\
- \\
0 \\
--\end{array}$ \\
\hline $\begin{array}{l}\text { IV } \\
\text { R }\end{array}$ & $\begin{array}{l}\text { Very High } \mathrm{Al} \\
\text { Very High } \mathrm{NO}_{3} \\
\text { Very High } \mathrm{Na} \\
\text { High Fission Products } \\
\text { Medium Iron } \\
\text { Medium } \mathrm{Cr} \\
\text { Medium } \mathrm{U} \\
\text { Medium } \mathrm{PO}_{4} \\
\text { Medium } \mathrm{Mn} \\
\text { Low F } \\
\text { No Bi } \\
\text { No La }\end{array}$ & $\begin{array}{l}\mathrm{Al} \\
\mathrm{Bi} \\
\mathrm{Cr} \\
\mathrm{Fe} \\
\mathrm{La} \\
\mathrm{Mn} \\
\mathrm{Na} \\
\mathrm{U} \\
\mathrm{NO}_{3} \\
\mathrm{PO}_{4}(\mathrm{aq}) \\
\mathrm{F} \\
\text { Fission Products }\end{array}$ & $\begin{array}{l}++ \\
-+ \\
0 \\
- \\
- \\
- \\
+ \\
+ \\
+ \\
0 \\
- \\
+\end{array}$ & & $\begin{array}{c}+ \\
+- \\
0 \\
- \\
0 \\
++ \\
+ \\
0 \\
0 \\
- \\
- \\
+\end{array}$ & $\begin{array}{c}+++ \\
-- \\
0 \\
- \\
-- \\
0 \\
+ \\
0 \\
+ \\
- \\
- \\
++\end{array}$ & $\begin{array}{c}++ \\
-- \\
0 \\
- \\
0 \\
++ \\
+ \\
+ \\
0 \\
- \\
- \\
0\end{array}$ \\
\hline $\begin{array}{c}\mathrm{XI} \\
1 \mathrm{C} \mathrm{TBP}\end{array}$ & $\begin{array}{l}\text { Very } \mathrm{High} \mathrm{NO}_{3} \\
\mathrm{High} \mathrm{Na}(\sim \text { Very High) } \\
\mathrm{High} \mathrm{Al} \\
\mathrm{High} \mathrm{Bi} \\
{\mathrm{High} \mathrm{PO}_{4}} \\
\mathrm{High} \mathrm{Fe} \\
\text { Medium U } \\
\text { Medium Fission Products } \\
\text { Medium F } \\
\text { Medium } \mathrm{Cr} \\
\text { No La } \\
\text { No Mn }\end{array}$ & $\begin{array}{l}\mathrm{Al} \\
\mathrm{Bi} \\
\mathrm{Cr} \\
\mathrm{Fe} \\
\mathrm{La} \\
\mathrm{Mn} \\
\mathrm{Na} \\
\mathrm{U} \\
\mathrm{NO}_{3} \\
\mathrm{PO}_{4} \text { (aq) } \\
\mathrm{F} \\
\text { Fission Products }\end{array}$ & $\begin{array}{l}+ \\
0 \\
0 \\
0 \\
-- \\
-- \\
0 \\
+ \\
+ \\
+ \\
0 \\
0\end{array}$ & $\begin{array}{c}- \\
+++ \\
0 \\
+ \\
0 \\
-- \\
- \\
0 \\
0 \\
+ \\
+ \\
-\end{array}$ & & $\begin{array}{c}++ \\
0 \\
0 \\
0 \\
-- \\
- \\
0 \\
0 \\
+ \\
0 \\
0 \\
+\end{array}$ & $\begin{array}{l}+ \\
0 \\
0 \\
0 \\
0 \\
0 \\
0 \\
+ \\
0 \\
0 \\
0 \\
-\end{array}$ \\
\hline
\end{tabular}


Table 4.10. (contd)

\begin{tabular}{|c|c|c|c|c|c|c|c|}
\hline \multirow{2}{*}{$\begin{array}{c}\text { SORWT } \\
\text { Group }\end{array}$} & \multirow{2}{*}{$\begin{array}{c}\text { Observed } \\
\text { Characteristics } \\
\text { of SORWT Group }\end{array}$} & \multirow{2}{*}{$\begin{array}{l}\text { Comparison } \\
\text { Analytes }\end{array}$} & \multicolumn{5}{|c|}{ Pairwise Comparison Group } \\
\hline & & & $\begin{array}{c}\text { Group } \\
\text { VII }\end{array}$ & $\begin{array}{c}\text { Group } \\
\text { IV }\end{array}$ & $\begin{array}{c}\text { Group } \\
\text { XII }\end{array}$ & $\begin{array}{c}\text { Group } \\
\text { XV }\end{array}$ & $\begin{array}{c}\text { Group } \\
\text { XVI }\end{array}$ \\
\hline $\begin{array}{c}X V \\
2 C 224\end{array}$ & $\begin{array}{l}\mathrm{High} \mathrm{Na} \\
\mathrm{High} \mathrm{NO}_{3} \\
\mathrm{High} \mathrm{Bi} \\
\mathrm{High} \mathrm{PO}_{4} \\
\mathrm{High} \mathrm{Fe} \\
\text { Medium F } \\
\text { Medium La } \\
\text { Medium Mn } \\
\text { Medium } \mathrm{Cr} \\
\text { Medium U } \\
\text { Low Al } \\
\text { Low Fission Products }\end{array}$ & $\begin{array}{l}\mathrm{Al} \\
\mathrm{Bi} \\
\mathrm{Cr} \\
\mathrm{Fe} \\
\mathrm{La} \\
\mathrm{Mn} \\
\mathrm{Na} \\
\mathrm{U} \\
\mathrm{NO}_{3} \\
\mathrm{PO}_{4}(\mathrm{aq}) \\
\mathrm{F} \\
\text { Fission Products }\end{array}$ & $\begin{array}{l} \\
0 \\
0 \\
0 \\
- \\
- \\
0 \\
+ \\
0 \\
+ \\
0 \\
-\end{array}$ & $\begin{array}{c}-- \\
+++ \\
0 \\
+ \\
++ \\
0 \\
- \\
0 \\
- \\
+ \\
+ \\
--\end{array}$ & $\begin{array}{c}- \\
0 \\
0 \\
0 \\
++ \\
++ \\
0 \\
0 \\
- \\
0 \\
0 \\
-\end{array}$ & & $\begin{array}{c}0 \\
0 \\
0 \\
++ \\
++ \\
0 \\
+ \\
- \\
0 \\
0 \\
--\end{array}$ \\
\hline $\begin{array}{c}\text { XVI } \\
2 \text { C 5-6 }\end{array}$ & $\begin{array}{l}\text { Very } \mathrm{High} \mathrm{NO}_{3} \\
\mathrm{High} \mathrm{Na} \text { ( Very High) } \\
\mathrm{High} \mathrm{Bi} \\
\mathrm{High}^{\mathrm{PO}}{ }_{4} \\
\mathrm{High} \mathrm{Fe} \\
\text { High Fission Products } \\
\text { Medium F } \\
\text { Medium Cr } \\
\text { Medium Al } \\
\text { Low U } \\
\text { No La } \\
\text { No Mn }\end{array}$ & $\begin{array}{l}\mathrm{Al} \\
\mathrm{Bi} \\
\mathrm{Cr} \\
\mathrm{Fe} \\
\mathrm{La} \\
\mathrm{Mn} \\
\mathrm{Na} \\
\mathrm{U} \\
\mathrm{NO}_{3} \\
\mathrm{PO}_{4} \text { (aq) } \\
\mathrm{F} \\
\text { Fission Products }\end{array}$ & $\begin{array}{l}0 \\
0 \\
0 \\
0 \\
-- \\
-- \\
0 \\
0 \\
+ \\
+ \\
0 \\
+\end{array}$ & $\begin{array}{c}-- \\
+++ \\
0 \\
+ \\
0 \\
- \\
- \\
- \\
0 \\
+ \\
+ \\
0\end{array}$ & $\begin{array}{l}- \\
0 \\
0 \\
0 \\
0 \\
0 \\
0 \\
- \\
0 \\
0 \\
0 \\
+\end{array}$ & $\begin{array}{l}+ \\
0 \\
0 \\
0 \\
-- \\
- \\
0 \\
- \\
+ \\
0 \\
0 \\
++\end{array}$ & \\
\hline
\end{tabular}

Table 4.11. Comparison of Observed to Expected Characteristics

\begin{tabular}{|c|c|c|c|c|c|c|}
\hline \multirow[b]{2}{*}{$\begin{array}{l}\text { SORWT } \\
\text { Group }\end{array}$} & \multirow[b]{2}{*}{$\begin{array}{l}\text { Comparison of Group } \\
\text { Characteristic Summaries }\end{array}$} & \multicolumn{5}{|c|}{ Pairwise Comparison Group } \\
\hline & & $\begin{array}{c}\text { Group } \\
\text { VII }\end{array}$ & $\begin{array}{c}\text { Group } \\
\text { IV }\end{array}$ & $\begin{array}{c}\text { Group } \\
\text { XII }\end{array}$ & $\begin{array}{c}\text { Group } \\
\text { XV }\end{array}$ & $\begin{array}{l}\text { Group } \\
\text { XVI }\end{array}$ \\
\hline VII & $11 / 12$ & & & & & 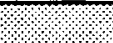 \\
\hline IV & $8 / 10$ & $9 / 10$ & & & & \\
\hline XII & $11 / 12(\sim 12 / 12)$ & $10 / 12$ & $7 / 10$ & & & \\
\hline$\overline{\mathrm{XV}}$ & $11 / 12$ & $10 / 12$ & $7 / 10$ & $10 / 12$ & & \\
\hline$\overline{\mathrm{XVI}}$ & $10 / 12(\sim 11 / 12)$ & $11 / 12$ & $8 / 10$ & $11 / 12$ & $9 / 12$ & \\
\hline
\end{tabular}




\subsection{Nominal Compositions and Inventory of Five SORWT Groups}

The nominal compositions of Groups VII, IV, XII, XV, and XVI were determined by calculating a mean concentration for each of the analytes included in the verification study across the tanks sampled within a particular SORWT group. The variance around these average group concentrations was also calculated. The inventory for each group was determined by projecting the average concentration to the total waste volume of the group.

In Section 4, Table 4.7 describes the nominal compositions of Groups VII, IV, XII, XV, and XVI. The overall composition (the nominal composition of all tanks regardless of group) is also included for comparison. In this section, Tables 5.1 through 5.5 describe each group individually, along with the corresponding nominal composition. The description of each group includes the number of tanks, the name of each tank, the primary and secondary waste types, and the total waste volume.

The nominal compositions of each group are based on the 20 analytes studied. The density and $\mathrm{pH}$ of each group are also included for comparison. The mean concentrations and coefficients of variance were calculated using the data from all core composites analyzed within the appropriate group. The mean concentration is listed in micrograms of analyte per gram of waste with the exception of ${ }^{137} \mathrm{Cs}$, ${ }^{90} \mathrm{Sr}$, and ${ }^{239 / 240} \mathrm{Pu}$. These values are listed as microcuries of radioactivity per gram of waste.

The $\mathrm{CV}$ is defined as the standard deviation divided by the mean concentration. The mass of each analyte was determined using the mean density and total waste volume of the group, the mean concentration of the analyte, and a conversion factor to obtain the appropriate units. The mass of each analyte and the total mass are listed in kilograms. The following equations illustrate the calculations performed to obtain the inventories for each group. Subscript A indicates analyte properties, while subscript W indicates total waste properties.

$$
\begin{aligned}
& \text { Mass }_{\mathrm{W}}\left(\mathrm{kg}_{\mathrm{w}}\right)=\underset{\text { Total }}{\text { Waste }}\left(\mathrm{kgal}_{\mathrm{W}}\right) * \frac{1,000 \mathrm{gal}_{\mathrm{W}}}{\mathrm{kgal}_{\mathrm{W}}} * \frac{3.785 \mathrm{~L}_{\mathrm{W}}}{\mathrm{gal}_{\mathrm{W}}} * \frac{1,000 \mathrm{ml}_{\mathrm{W}}}{\mathrm{L}_{\mathrm{W}}} * \text { Denisty } \frac{\mathrm{g}_{\mathrm{W}}}{\mathrm{ml}_{\mathrm{W}}} * \frac{\mathrm{kg}_{\mathrm{W}}}{1,000 \mathrm{~g}_{\mathrm{W}}} \\
& \operatorname{Mass}_{\mathrm{A}}\left(\mathrm{kg}_{\mathrm{A}}\right)=\text { Mass }_{\mathrm{W}}\left(\mathrm{kg}_{\mathrm{W}}\right) * \frac{1,000 \mathrm{~g}_{\mathrm{W}}}{\mathrm{kg}_{\mathrm{W}}} * \text { Analyte } \frac{\mu \mathrm{g}_{\mathrm{A}}}{\text { Conc. }} * \frac{\mathrm{g}_{\mathrm{A}}}{\mathrm{g}_{\mathrm{W}}} * \frac{\mathrm{kg}_{\mathrm{A}}}{10^{6} \mu \mathrm{g}_{\mathrm{A}}} * \frac{1,00 \mathrm{~g}_{\mathrm{A}}}{1,} \\
& \text { Radioactivity }_{\mathrm{A}}\left(\mathrm{Ci}_{\mathrm{A}}\right)=\text { Mass }_{\mathrm{W}}\left(\mathrm{kg}_{\mathrm{W}}\right) * \frac{1,000 \mathrm{~g}_{\mathrm{W}}}{\mathrm{kg}_{\mathrm{W}}} * \begin{array}{c}
\text { Analyte } \\
\text { Activity } \\
\text { Conc. }
\end{array} \frac{\mathrm{Ci}_{\mathrm{A}}}{\mathrm{g}_{\mathrm{W}}} * \frac{\mathrm{Ci}_{\mathrm{A}}}{10^{6} \mathrm{CCi}_{\mathrm{A}}}
\end{aligned}
$$


Table 5.1. Nominal Composition and Inventory of Group VII

\begin{tabular}{|c|c|c|c|c|}
\hline \multicolumn{5}{|c|}{ Description of Individual Tanks Within Group VII } \\
\hline \multicolumn{5}{|c|}{ No. of Tanks: 8} \\
\hline Tank Name & $\begin{array}{c}\text { Number of Cores } \\
\text { Taken }\end{array}$ & Primary Waste Type & $\begin{array}{l}\text { Secondary } \\
\text { Waste Type }\end{array}$ & $\begin{array}{c}\text { Waste Volume } \\
\text { (kgal) }\end{array}$ \\
\hline$\overline{\mathrm{B}-201}$ & $\overline{2}$ & 224 & & 29 \\
\hline B-202 & 2 & 224 & & 27 \\
\hline B-203 & 0 & 224 & & 51 \\
\hline B-204 & 0 & 224 & & 50 \\
\hline T-201 & 0 & 224 & & 29 \\
\hline $\mathrm{T}-202$ & 0 & 224 & & 21 \\
\hline $\mathrm{T}-203$ & 0 & 224 & & 35 \\
\hline T-204 & 0 & 224 & & 38 \\
\hline Total: & 4 & & & 280 \\
\hline \multicolumn{5}{|c|}{ Analyte Inventory and Mean Concentrations of Group VII } \\
\hline \multirow[t]{2}{*}{ Analytes } & Mean Concentration & Coeff. of Variance & \multicolumn{2}{|c|}{ Inventory } \\
\hline & $(\mu \mathrm{g} / \mathrm{g})$ & & \multicolumn{2}{|c|}{$(\mathrm{kg})$} \\
\hline$\overline{\mathrm{Al}}$ & 3,490 & 1.35 & \multicolumn{2}{|c|}{4,331} \\
\hline $\mathrm{Bi}$ & 61,753 & 0.528 & \multicolumn{2}{|c|}{76,637} \\
\hline $\mathrm{Cr}$ & 2,835 & 0.22 & \multicolumn{2}{|c|}{3,518} \\
\hline $\mathrm{Fe}$ & 10,156 & 0.487 & \multicolumn{2}{|c|}{12,604} \\
\hline $\mathbf{L a}$ & 13,592 & 0.092 & \multicolumn{2}{|c|}{16,868} \\
\hline Mn & 14,508 & 0.574 & \multicolumn{2}{|c|}{18,005} \\
\hline $\mathrm{Na}$ & 41,364 & 0.206 & \multicolumn{2}{|c|}{51,334} \\
\hline $\mathrm{Pb}$ & 1,125 & 0.574 & \multicolumn{2}{|c|}{1,396} \\
\hline $\mathrm{Si}$ & 15,648 & 1.34 & \multicolumn{2}{|c|}{19,420} \\
\hline $\mathrm{Zr}$ & 28.9 & 0.959 & \multicolumn{2}{|c|}{36} \\
\hline $\mathrm{U}$ & 414 & 0.561 & \multicolumn{2}{|c|}{514} \\
\hline $\mathrm{PO}_{4}(\mathrm{aq})$ & 1,706 & 0.289 & \multicolumn{2}{|c|}{2,117} \\
\hline $\mathrm{NO}_{3}$ & 56,589 & 0.131 & \multicolumn{2}{|c|}{70,228} \\
\hline $\mathrm{NO}_{2}$ & 719 & 0.286 & \multicolumn{2}{|c|}{892} \\
\hline F & 6,134 & 0.073 & \multicolumn{2}{|c|}{7,612} \\
\hline $\mathrm{Cl}$ & 1,225 & 0.38 & \multicolumn{2}{|c|}{1,520} \\
\hline \multirow[t]{2}{*}{ TOC } & 8,768 & 1.42 & \multicolumn{2}{|c|}{ NA } \\
\hline & $(\mu \mathrm{Ci} / \mathrm{g})$ & & \multicolumn{2}{|c|}{ (Ci) } \\
\hline${ }^{137} \mathrm{Cs}$ & 0.403 & 1.11 & \multicolumn{2}{|c|}{500} \\
\hline${ }^{90} \mathrm{Sr}$ & 3.17 & 0.595 & \multicolumn{2}{|c|}{3,934} \\
\hline${ }^{239 / 240} \mathrm{Pu}$ & 0.606 & 0.897 & . & 152 \\
\hline & $(\mathrm{g} / \mathrm{ml})$ & & & kg) \\
\hline Density & 1.171 & 0.114 & & 1,026 \\
\hline $\mathrm{pH}$ & NA & NA & & \\
\hline
\end{tabular}


Table 5.2. Nominal Composition and Inventory of Group IV

\begin{tabular}{|c|c|c|c|c|}
\hline \multicolumn{5}{|c|}{ Description of Individual Tanks Within Group IV } \\
\hline \multicolumn{5}{|c|}{ No. of Tanks: 10} \\
\hline Tank Name & Number of Cores Taken & Primary Waste Type & $\begin{array}{l}\text { Secondary } \\
\text { Waste Type }\end{array}$ & $\begin{array}{c}\text { Waste Volume } \\
\text { (kgal) }\end{array}$ \\
\hline$\overline{S X}-112$ & 0 & $\overline{\mathbf{R}}$ & & 92 \\
\hline SX-108 & 0 & $\mathbf{R}$ & & 87 \\
\hline SX-107 & 0 & $\mathbf{R}$ & & 104 \\
\hline SX-109 & 0 & $\mathbf{R}$ & & 250 \\
\hline SX-115 & 0 & $\mathbf{R}$ & & 12 \\
\hline SX-110 & 0 & $\mathbf{R}$ & & 62 \\
\hline$S X-111$ & 0 & $\mathbf{R}$ & & 125 \\
\hline sX-114 & 0 & $\mathbf{R}$ & & 181 \\
\hline $\mathrm{U}-101$ & 0 & $\mathbf{R}$ & & 25 \\
\hline S-104 & 3 & $\mathbf{R}$ & & 294 \\
\hline Total: & 3 & & & 1,232 \\
\hline \multicolumn{5}{|c|}{$\frac{1}{\text { Analyte Inventory and Mean Concentrations of Group IV }}$} \\
\hline \multirow[t]{2}{*}{ Analytes } & Mean Concentration & Coeff. of Variance & \multicolumn{2}{|c|}{ Inventory } \\
\hline & $(\mu \mathrm{g} / \mathrm{g})$ & & \multicolumn{2}{|c|}{$(\mathrm{kg})$} \\
\hline$\overline{\mathrm{Al}}$ & 117,000 & 0.034 & \multicolumn{2}{|c|}{894,759} \\
\hline $\mathrm{Bi}$ & 38.8 & 0.192 & \multicolumn{2}{|c|}{297} \\
\hline $\mathrm{Cr}$ & 2,353 & 0.062 & \multicolumn{2}{|c|}{17,995} \\
\hline $\mathrm{Fe}$ & 1,424 & 0.469 & \multicolumn{2}{|c|}{10,890} \\
\hline $\mathrm{La}$ & 9.41 & 0.117 & \multicolumn{2}{|c|}{72} \\
\hline Mn & 1,150 & 0.336 & \multicolumn{2}{|c|}{8,795} \\
\hline $\mathrm{Na}$ & 118,250 & 0.031 & \multicolumn{2}{|c|}{904,319} \\
\hline $\mathrm{Pb}$ & 38.6 & 0.076 & \multicolumn{2}{|c|}{295} \\
\hline $\mathrm{Si}$ & 1,326 & 0.282 & \multicolumn{2}{|c|}{10,141} \\
\hline $\mathrm{Z}_{\mathbf{r}}$ & 21.2 & 0.463 & \multicolumn{2}{|c|}{162} \\
\hline $\mathrm{U}$ & 6,685 & 0.103 & \multicolumn{2}{|c|}{51,124} \\
\hline $\mathrm{PO}_{4}(\mathrm{aq})$ & 1,310 & 0.352 & \multicolumn{2}{|c|}{10,018} \\
\hline $\mathrm{NO}_{3}$ & 186,300 & 0.076 & \multicolumn{2}{|c|}{$1,424,732$} \\
\hline $\mathrm{NO}_{2}$ & 25,730 & 0.122 & \multicolumn{2}{|c|}{196,771} \\
\hline $\mathrm{F}$ & 132 & 0.346 & \multicolumn{2}{|c|}{1,009} \\
\hline $\mathrm{Cl}$ & 3,162 & 0.05 & & \\
\hline TOC & 1,606 & 0.35 & & \\
\hline & $(\mu \mathrm{Ci} / \mathrm{g})$ & & & \\
\hline${ }^{137} \mathrm{Cs}$ & 62.3 & 0.053 & & 440 \\
\hline${ }^{90} \mathrm{Sr}$ & 310 & 0.081 & &, 730 \\
\hline${ }^{239240} \mathrm{Pu}$ & 0.282 & 0.373 & & \\
\hline & $(\mathrm{g} / \mathrm{ml})$ & & & g) \\
\hline Density & 1.64 & NA & &, 517 \\
\hline $\mathrm{pH}$ & 12.8 & 0.074 & & \\
\hline
\end{tabular}


Table 5.3. Nominal Composition and Inventory of Group XII

\begin{tabular}{|c|c|c|c|c|}
\hline \multicolumn{5}{|c|}{ Description of Individual Tanks Within Group XII } \\
\hline \multicolumn{5}{|c|}{ No. of Tanks: 4} \\
\hline Tank Name & $\begin{array}{c}\text { Number of Cores } \\
\text { Taken }\end{array}$ & $\begin{array}{c}\text { Primary Waste } \\
\text { Type }\end{array}$ & $\begin{array}{l}\text { Secondary } \\
\text { Waste Type }\end{array}$ & $\begin{array}{c}\text { Waste } \\
\text { Volume (kgal) }\end{array}$ \\
\hline $\mathrm{C}-110$ & $\overline{3}$ & $\overline{1 \mathrm{C}}$ & $\overline{\mathrm{TBP}}$ & 187 \\
\hline BX-107 & 2 & $1 \mathrm{C}$ & TBP & 345 \\
\hline $\mathrm{T}-108$ & 0 & $1 \mathrm{C}$ & TBP & 44 \\
\hline B-106 & 0 & $1 \mathrm{C}$ & TBP & 117 \\
\hline Total: & 5 & & & 693 \\
\hline \multicolumn{5}{|c|}{ Analyte Inventory and Mean Concentrations of Group XII } \\
\hline \multirow[t]{2}{*}{ Analytes } & Mean Concentration & Coeff. of Variance & \multicolumn{2}{|c|}{ Inventory } \\
\hline & $(\mu \mathrm{g} / \mathrm{g})$ & & \multicolumn{2}{|c|}{$(\mathrm{kg})$} \\
\hline$\overline{\mathrm{Al}}$ & 14,323 & 0.099 & \multicolumn{2}{|c|}{48,314} \\
\hline $\mathrm{Bi}$ & 17,356 & 0.305 & \multicolumn{2}{|c|}{58,545} \\
\hline $\mathrm{Cr}$ & 685 & 0.393 & \multicolumn{2}{|c|}{2,311} \\
\hline $\mathrm{Fe}$ & 10,812 & 0.13 & \multicolumn{2}{|c|}{$36, \dot{4} 71$} \\
\hline $\mathrm{La}$ & 7.97 & 0.004 & \multicolumn{2}{|c|}{27} \\
\hline Mn & 58.1 & 0.298 & \multicolumn{2}{|c|}{196} \\
\hline $\mathrm{Na}$ & 91,133 & 0.105 & \multicolumn{2}{|c|}{307,408} \\
\hline $\mathrm{Pb}$ & 181 & 0.828 & \multicolumn{2}{|c|}{611} \\
\hline $\mathrm{Si}$ & 6,933 & 0.105 & \multicolumn{2}{|c|}{23,386} \\
\hline $\mathrm{Zr}$ & 153 & 0.295 & \multicolumn{2}{|c|}{516} \\
\hline $\mathrm{U}$ & 4,248 & 1.7 & \multicolumn{2}{|c|}{14,329} \\
\hline $\mathrm{PO}_{4}(\mathrm{aq})$ & 22,256 & 0.523 & \multicolumn{2}{|c|}{75,074} \\
\hline $\mathrm{NO}_{3}$ & 121,261 & 0.15 & \multicolumn{2}{|c|}{409,036} \\
\hline $\mathrm{NO}_{2}$ & 7,638 & 0.602 & \multicolumn{2}{|c|}{25,764} \\
\hline $\mathrm{F}$ & 8,261 & 0.206 & \multicolumn{2}{|c|}{27,866} \\
\hline $\mathrm{Cl}$ & 1,116 & 0.332 & \multicolumn{2}{|c|}{3,764} \\
\hline \multirow[t]{2}{*}{ TOC } & 739 & 0.323 & \multicolumn{2}{|c|}{2,493} \\
\hline & $(\mu \mathrm{Ci} / \mathrm{g})$ & & \multicolumn{2}{|c|}{$(\mathrm{Ci})$} \\
\hline${ }^{137} \mathrm{Cs}$ & 18.5 & 0.263 & \multicolumn{2}{|c|}{62,404} \\
\hline${ }^{90} \mathrm{Sr}$ & 7.19 & 0.409 & \multicolumn{2}{|c|}{24,253} \\
\hline${ }^{239 / 240} \mathrm{Pu}$ & 0.07 & 0.432 & \multicolumn{2}{|c|}{236} \\
\hline & $(\mathrm{g} / \mathrm{ml})$ & & \multicolumn{2}{|c|}{$(\mathrm{kg})$} \\
\hline Density & 1.286 & 0.124 & & 3,184 \\
\hline $\mathrm{pH}$ & 10.6 & 0.063 & & \\
\hline
\end{tabular}


Table 5.4. Nominal Composition and Inventory of Group XV

\begin{tabular}{|c|c|c|c|c|}
\hline \multicolumn{5}{|c|}{ Description of Individual Tanks Within Group XV } \\
\hline \multicolumn{5}{|c|}{ No. of Tanks: 3} \\
\hline Tank Name & $\begin{array}{c}\text { Number of Cores } \\
\text { Taken }\end{array}$ & $\begin{array}{c}\text { Primary Waste } \\
\text { Type }\end{array}$ & $\begin{array}{c}\text { Secondary } \\
\text { Waste Type }\end{array}$ & $\begin{array}{c}\text { Waste } \\
\text { Volume (kgal) }\end{array}$ \\
\hline $\mathrm{T}-110$ & 0 & $2 \mathrm{C}$ & 224 & $\overline{379}$ \\
\hline $\mathrm{T}-112$ & 0 & $2 \mathrm{C}$ & 224 & 67 \\
\hline $\mathrm{T}-111$ & 2 & $2 \mathrm{C}$ & 224 & 458 \\
\hline Total: & 2 & & & 904 \\
\hline \multicolumn{5}{|c|}{ Analyte Inventory and Mean Concentrations of Group XV } \\
\hline \multirow[t]{2}{*}{ Analytes } & Mean Concentration & Coeff. of Variance & \multicolumn{2}{|c|}{ Inventory } \\
\hline & $(\mu \mathrm{g} / \mathrm{g})$ & & \multicolumn{2}{|c|}{$(\mathrm{kg})$} \\
\hline$\overline{\mathrm{Al}}$ & 570 & 0.189 & \multicolumn{2}{|c|}{2,409} \\
\hline $\mathrm{Bi}$ & 23,562 & 0.138 & \multicolumn{2}{|c|}{99,567} \\
\hline $\mathrm{Cr}$ & 1,799 & 0.043 & \multicolumn{2}{|c|}{7,602} \\
\hline $\mathrm{Fe}$ & 18,038 & 0.121 & \multicolumn{2}{|c|}{76,224} \\
\hline $\mathrm{La}$ & 4,108 & 0.15 & \multicolumn{2}{|c|}{17,359} \\
\hline $\mathrm{Mn}$ & 6,282 & 0.042 & \multicolumn{2}{|c|}{26,546} \\
\hline $\mathrm{Na}$ & 36,950 & 0.073 & \multicolumn{2}{|c|}{156,141} \\
\hline $\mathrm{Pb}$ & 365 & 0.288 & \multicolumn{2}{|c|}{1,542} \\
\hline $\mathrm{Si}$ & 5,565 & 0.056 & \multicolumn{2}{|c|}{23,516} \\
\hline $\mathrm{Zr}$ & 4 & 0.002 & \multicolumn{2}{|c|}{17} \\
\hline $\mathrm{U}$ & 2,555 & 0.481 & \multicolumn{2}{|c|}{10,797} \\
\hline $\mathrm{PO}_{4}(\mathrm{aq})$ & 15,538 & 0.1 & \multicolumn{2}{|c|}{65,659} \\
\hline $\mathrm{NO}_{3}$ & 41,238 & 0.079 & \multicolumn{2}{|c|}{174,260} \\
\hline $\mathrm{NO}_{2}$ & 897 & 0.198 & \multicolumn{2}{|c|}{3,790} \\
\hline $\mathrm{F}$ & 2,301 & 0.377 & \multicolumn{2}{|c|}{9,723} \\
\hline $\mathrm{Cl}$ & 450 & 0.102 & \multicolumn{2}{|c|}{1,902} \\
\hline \multirow[t]{2}{*}{ TOC } & 3,119 & 0.255 & \multicolumn{2}{|c|}{13,180} \\
\hline & $(\mu \mathrm{Ci} / \mathrm{g})$ & & \multicolumn{2}{|c|}{ (Ci) } \\
\hline${ }^{137} \mathrm{Cs}$ & 0.166 & 0.377 & \multicolumn{2}{|c|}{701} \\
\hline${ }^{90} \mathrm{Sr}$ & 5.414 & 0.372 & \multicolumn{2}{|c|}{22,878} \\
\hline${ }^{239 / 240} \mathrm{Pu}$ & 0.139 & 0.051 & \multicolumn{2}{|c|}{587} \\
\hline & $(\mathrm{g} / \mathrm{ml})$ & & \multicolumn{2}{|c|}{$(\mathrm{kg})$} \\
\hline Density & 1.235 & 0.052 & \multirow{2}{*}{\multicolumn{2}{|c|}{$4,225,725$}} \\
\hline $\mathrm{pH}$ & 11.6 & & & \\
\hline
\end{tabular}


Table 5.5. Nominal Composition and Inventory of Group XVI

\begin{tabular}{|c|c|c|c|c|}
\hline \multicolumn{5}{|c|}{ Description of Individual Tanks Within Group XVI } \\
\hline \multicolumn{5}{|c|}{ No. of Tanks: 3} \\
\hline Tank Name & $\begin{array}{c}\text { Number of Cores } \\
\text { Taken }\end{array}$ & $\begin{array}{c}\text { Primary Waste } \\
\text { Type }\end{array}$ & $\begin{array}{l}\text { Secondary } \\
\text { Waste Type }\end{array}$ & $\begin{array}{c}\text { Waste } \\
\text { Volume (kgal) }\end{array}$ \\
\hline$\overline{\mathrm{B}-112}$ & 0 & $\overline{2 C}$ & $5-6$ & 33 \\
\hline B-110 & 7 & $2 \mathrm{C}$ & $5-6$ & 246 \\
\hline B-111 & 2 & $2 \mathrm{C}$ & $5-6$ & 237 \\
\hline Total: & 9 & & & 516 \\
\hline \multicolumn{5}{|c|}{ Analyte Inventory and Mean Concentrations of Group XVI } \\
\hline \multirow[t]{2}{*}{ Analytes } & Mean Concentration & Coeff. of Variance & \multicolumn{2}{|c|}{ Inventory } \\
\hline & $(\mu \mathrm{g} / \mathrm{g})$ & & \multicolumn{2}{|c|}{$(\mathrm{kg})$} \\
\hline$\overline{\mathrm{Al}}$ & 1,425 & 0.692 & \multicolumn{2}{|c|}{3,535} \\
\hline $\mathrm{Bi}$ & 19,354 & 0.127 & \multicolumn{2}{|c|}{48,005} \\
\hline $\mathrm{Cr}$ & 854 & 0.163 & \multicolumn{2}{|c|}{2,118} \\
\hline $\mathrm{Fe}$ & 17,486 & 0.188 & \multicolumn{2}{|c|}{43,372} \\
\hline $\mathrm{La}$ & 73.6 & 0.302 & \multicolumn{2}{|c|}{183} \\
\hline $\mathrm{Mn}$ & 97.2 & 0.26 & \multicolumn{2}{|c|}{241} \\
\hline $\mathrm{Na}$ & 96,359 & 0.061 & \multicolumn{2}{|c|}{239,008} \\
\hline $\mathrm{Pb}$ & 750 & 0.732 & \multicolumn{2}{|c|}{1,860} \\
\hline $\mathrm{Si}$ & 10,173 & 0.264 & \multicolumn{2}{|c|}{25,233} \\
\hline $\mathrm{Zr}$ & 134 & 1.6 & \multicolumn{2}{|c|}{332} \\
\hline $\mathrm{U}$ & 209 & 0.164 & \multicolumn{2}{|c|}{518} \\
\hline $\mathrm{PO}_{4}(\mathrm{aq})$ & 24,555 & 0.067 & \multicolumn{2}{|c|}{60,906} \\
\hline $\mathrm{NO}_{3}$ & 145,000 & 0.361 & \multicolumn{2}{|c|}{359,656} \\
\hline $\mathrm{NO}_{2}$ & 22,910 & 0.756 & \multicolumn{2}{|c|}{56,826} \\
\hline $\mathrm{F}$ & 1,761 & 0.147 & \multicolumn{2}{|c|}{4,368} \\
\hline $\mathrm{Cl}$ & 1,153 & 0.152 & \multicolumn{2}{|c|}{2,860} \\
\hline \multirow[t]{2}{*}{ TOC } & 634 & 0.675 & \multicolumn{2}{|c|}{1,573} \\
\hline & $(\mu \mathrm{Ci} / \mathrm{g})$ & & \multicolumn{2}{|c|}{$(\mathrm{Ci})$} \\
\hline \multirow{4}{*}{$\begin{array}{c}{ }^{137} \mathrm{Cs} \\
{ }^{90} \mathrm{Sr} \\
{ }^{239 / 240} \mathrm{Pu}\end{array}$} & 40.6 & 1.39 & \multicolumn{2}{|c|}{100,704} \\
\hline & 133 & 0.751 & \multicolumn{2}{|c|}{329,891} \\
\hline & 0.107 & 0.185 & \multicolumn{2}{|c|}{265} \\
\hline & $(\mathrm{g} / \mathrm{ml})$ & & \multicolumn{2}{|c|}{$(\mathrm{kg})$} \\
\hline Density & 1.27 & 0.074 & & 0,386 \\
\hline $\mathrm{pH}$ & 8.22 & 0.054 & & \\
\hline
\end{tabular}




\subsection{Nominal Composition of Group VII}

The nominal composition of Group VII is listed in Table 5.1. Group VII consists of eight tanks containing 224 waste exclusively. Notice the significantly higher concentrations of La and $\mathrm{Mn}$, which are indicative of 224 waste. Also, notice that the $\mathrm{PO}_{4}$ concentrations are an order of magnitude lower in Group VII than in the other groups containing $\mathrm{BiPO}_{4}$ process waste (Groups XII, XV, and XVI). This agrees with the predictions made earlier in this study.

Of the eight tanks in Group VII, B-201 and B-202 have been sampled. B-201 and B-202 each contain 29,000 and 27,000 gallons of waste, respectively; therefore, $20 \%$ of the total 280,000 gallons of waste has been sampled. The $\mathrm{pH}$ measurements for samples in Group VII were not available.

\subsection{Nominal Composition of Group IV}

Table 5.2 describes the nominal composition of the waste found in Group IV. All 10 tanks included in Group IV contain $\mathrm{R}$ waste. The high $\mathrm{Al}$, low Fe, and almost absent Bi concentrations are consistent with the predicted profile of $\mathrm{R}$ waste. The differences between Group IV and the other groups in this study are attributed to the fact that $\mathrm{R}$ waste is a REDOX process waste. All other groups included in the verification study consist of wastes from the $\mathrm{BiPO}_{4}$ process. This clearly demonstrates that observable differences exist in the waste and a logical categorization based on process origin is possible.

Although S-104 is the only tank that has been sampled from this group, it contains 294,000 of the total $1,232,000$ gallons of waste; this is approximately $24 \%$ of the waste found in Group IV. Furthermore, the composition of this tank can provide insight into other tanks with substantial quantities of $\mathrm{R}$ waste. A CV for the nominal density of Group IV is not listed because only one value could be found in the available literature.

\subsection{Nominal Composition of Group XII}

Table 5.3 describes the nominal composition of Group XII waste. These four tanks primarily contain $1 \mathrm{C}$ and TBP waste. The waste contains appreciable amounts of $\mathrm{Al}, \mathrm{Na}, \mathrm{NO}_{3}$, and $\mathrm{U}$ as would be expected from 1C and TBP waste. Tanks C-110 and BX-107, containing 187,000 and 345,000 gallons, respectively, have been sampled. This is approximately $77 \%$ of the 693,000 gallons of total waste volume in Group XII.

\subsection{Nominal Composition of Group XV}

The nominal composition of Group XV is described in Table 5.4. Although only one of the three tanks has been sampled, T-111 contains 458,000 of the total 904,000 gallons of waste material- $51 \%$ 
of the total waste volume. Group XV contains primarily $2 \mathrm{C}$ and 224 type wastes. The presence of 224 waste explains the high concentrations of $\mathrm{La}$ and $\mathrm{Mn}$, while the lack of fission products is indicative of both 224 and $2 \mathrm{C}$ wastes.

\subsection{Nominal Composition of Group XVI}

The nominal composition of Group XVI is listed in Table 5.5. Of the three tanks included in Group XVI, B-110 and B-111 have been sampled. Their combined waste volume of 483,000 gallons is $94 \%$ of the total waste volume in Group XVI. $2 \mathrm{C}$ and 5-6 are the primary waste types found in this group. The high concentration of fission products is due primarily to the presence of the 5-6 waste. As with $1 \mathrm{C}$ waste, 5-6 waste also has appreciable amounts of $\mathrm{Na}$ and $\mathrm{NO}_{3}$. 


\subsection{Conclusions and Recommendations}

The SORWT model presents a methodology to group SSTs that is both simple to understand and logical in its assumptions and construction. The SORWT model has predicted the existence of 24 groups of SSTs ranging from 22 tanks per group to two tanks per group. These 24 groups encompass 133 tanks and $93 \%$ of the total waste contained in SSTs. The first 14 groups (i.e., those that contain four tanks per group or more) represent 109 tanks and $83 \%$ of the total waste volume. This demonstrates the potential for using the SORWT model to efficiently allocate resources and to maximize characterization information gained by a minimum number of sampling events. The verification study has shown that the SST groups predicted by the SORWT model are statistically significant and reduce the variability in the concentrations for all analytes examined.

The SORWT model organizes a vast amount of information and presents clear options on which SSTs are more desirable to sample. The model is also simple and flexible in its ability to incorporate new parameters such as new SST analytical data, shifting programmatic needs, and/or risk assessment-oriented criteria.

This report presents the nominal composition, inventory, and uncertainty for five of the 24 SORWT groups, representing 28 tanks, $10 \%$ of the total waste volume, and $29 \%$ of the total sludge volume in SSTs. Consequently, this document provides a logical beginning framework for tank waste characterization until further information becomes available or different programmatic needs are identified.

\subsection{Recommended Tank Waste Sampling}

Tanks recommended for sampling based on the results of the SORWT model are listed in Tables 6.1 and 6.2. The list takes advantage of the SORWT model groups to establish a substantial amount of characterization information from a relatively small number of core and auger samples. Thirty-two additional core samples are recommended. If this new sampling and analysis information is combined with the existing data, nominal compositions of 104 tanks (70\% of the SSTs) could be established. This would represent approximately $79 \%$ of the total waste volume, $63 \%$ of the total sludge volume, and $88 \%$ of the salt cake volume.

Sampling priority for the following list of recommended sampling events should be based on sampling the largest SORWT groups first. In most cases, the largest volume tanks should be given higher priority. It is recognized that programmatic priorities and technical difficulties with the sampling equipment might not allow rigid implementation of the proposed sampling and priority and that suitable alternatives can be identified, should the tanks designated here not be deemed appropriate. If there is a significant (i.e., 6 months) delay in field deployment of the rotary-mode core sample truck, then auger samples instead of core samples from the major SORWT groups should seriously be considered to begin assessing the salt cake types of waste and other waste types contributing large 
Table 6.1. List of Recommended Core Samples

\begin{tabular}{|c|c|c|c|c|}
\hline Tank No. & $\begin{array}{l}\text { SORWT } \\
\text { Group }\end{array}$ & $\begin{array}{l}\text { No. of Core } \\
\text { Samples }\end{array}$ & Watch-List Status & $\begin{array}{c}\text { Total Waste Volume } \\
\text { in Tank (kgal) }\end{array}$ \\
\hline TX-105 & $\mathrm{I}$ & 2 & Organic & 609 \\
\hline$S-109$ & I & 2 & $\mathrm{NWL}^{(\mathrm{a})}$ & 568 \\
\hline S-108 & I & 2 & NWL & 604 \\
\hline $\mathrm{TX}-112$ & II & 2 & NWL & 649 \\
\hline $\mathrm{TX}-116$ & II & 2 & NWL & 631 \\
\hline TX-117 & II & 2 & NWL & 626 \\
\hline BY-106 & III & 2 & Ferrocyanide & 642 \\
\hline BY -105 & III & 2 & Ferrocyanide & 503 \\
\hline BY-104 & III & 2 & Ferrocyanide & 406 \\
\hline$S X-114$ & IV & 2 & High Heat & 181 \\
\hline $\mathrm{TX}-115$ & IX & 2 & NWL & 640 \\
\hline U-111 & IX & 2 & Organic & 329 \\
\hline U-107 & VI & 2 & Organic & 406 \\
\hline TX-118 & $\mathrm{VI}$ & 2 & Ferrocyanide, Organic & 347 \\
\hline $\mathrm{BX}-110$ & VIII & 2 & NWL & 198 \\
\hline B-107 & VIII & 2 & NWL & 165 \\
\hline Total & & 32 & & \\
\hline
\end{tabular}

Table 6.2. List of Recommended Auger Samples

\begin{tabular}{||c|c|c|c|c||}
\hline Tank No. & $\begin{array}{c}\text { SORWT } \\
\text { Group }\end{array}$ & $\begin{array}{c}\text { No. of Auger } \\
\text { Samples }\end{array}$ & $\begin{array}{c}\text { Watch-List } \\
\text { Status }\end{array}$ & $\begin{array}{c}\text { Total Waste Volume in } \\
\text { Tank (kgal) }\end{array}$ \\
\hline \hline TX-107 & I & 3 & NWL & 36 \\
TX-104 & I & 3 & NWL & 65 \\
\hline BX-106 & V & 3 & NWL & 46 \\
BX-101 & V & 3 & NWL & 43 \\
\hline SX-112 & IV & 3 & NWL & 92 \\
U-101 & IV & 3 & NWL & 25 \\
\hline \hline Total & & 18 & & \\
\hline
\end{tabular}


quantities of material to the overall waste inventory (e.g., $R$ waste). There is a significant lack of information regarding certain waste types, and auger sampling provides a means of acquiring relevant information quickly.

\subsection{Recommended Suite of Analyses}

The following suite of analyses is recommended at a minimum for the tank waste sampling events identified in the previous section. Table 6.3 presents the sample preparations and analytical procedures to be conducted on each composite sample. Additional analytical data requirements could be developed by other programs interested in the same tank wastes. The recommended suite of analyses is designed to determine the general characteristics of the waste and should be compatible with the available laboratory resources. Because the overall tank characteristics are of interest, laboratory analyses will likely be conducted on composite samples, with other programmatic analytical requirements needing narrower horizons being designated in the appropriate implementation documentation. This suite will capture the major cations, anions, $\mathrm{H}_{2} \mathrm{O}$, total organic carbon (TOC), waste energetic characteristics, gamma-emitting radionuclides $\left({ }^{137} \mathrm{Cs}\right),{ }^{90} \mathrm{Sr},{ }^{239 / 240} \mathrm{Pu}$, and total $\mathrm{U}$. The suite would also measure watersoluble cations and gamma emitters to determine waste solubility.

Table 6.3. Recommended Suite of Analyses

\begin{tabular}{|c|c|c||}
\hline Fusion Dissolution & Water Leach & Direct Sample \\
\hline ICP & Ion Chromatography & wt \% $\mathrm{H}_{2} \mathrm{O}$ \\
GEA $\left({ }^{137} \mathrm{Cs}\right)$ & GEA & TOC \\
RadChem $\left({ }^{90} \mathrm{Sr}\right)$ & ICP & DSC/TGA \\
Alpha Energy Analysis $\left({ }^{239 / 240} \mathrm{Pu}\right)$ & & \\
Laser Fluorimetry (Total U) & & \\
\hline
\end{tabular}




\subsection{References}

Adams, M. R., L. Jensen, and W. W. Schulz. 1986. Preliminary Assessment of the TRAC Model as a Predictor of Key Radionuclide Inventories. RHO-RE-EV-89 P, Rockwell Hanford Operations, Richland, Washington.

Anderson, J. D. 1990. A History of the 200 Area Tank Farms. WHC-MR-0132, Westinghouse Hanford Company, Richland, Washington.

Hanlon, B. M. 1990. Tank Farm Surveillance and Waste Status Summary Report for July 1990. WHC-EP-0182-28, Westinghouse Hanford Company, Richland, Washington.

Hanlon, B. M. 1994. Tank Farm Surveillance and Waste Status Summary Report for March 1994. WHC-EP-0182-72, Westinghouse Hanford Company, Richland, Washington.

Hill, J. G., W. I. Winters, B. C. Simpson, J. W. Buck, P. J. Chamberlain, and V. L. Hunter. 1991. Waste Characterization Plan for the Hanford Site Single-Shell Tanks-Appendix I: Test Plan for Sampling and Analysis of Ten Single-Shell Tanks. WHC-EP-0210 Rev. 3, Westinghouse Hanford Company, Richland, Washington.

Hill, J. G., and B. C. Simpson. 1994a. The Sort on Radioactive Waste Type Model: A Method to Sort Single Shell Tanks into Characteristic Groups. PNL-9814, Pacific Northwest Laboratory, Richland, Washington.

Hill, J. G., and B. C., Simpson. 1994b. The Sort on Radioactive Waste Type Model: A Method to Sort Single Shell Tanks into Characteristic Groups. PNL-9814, Rev. 1, Pacific Northwest Laboratory, Richland, Washington.

Jungfleisch, F. M. 1984. TRAC: A Preliminary Estimation of the Waste Inventories in Hanford Tanks Through 1980. SD-WM-TI-057, Rockwell Hanford Operations, Richland, Washington.

Morgan, L. G., W. W. Schulz, M. R. Adams, and K. W. Owens. 1988. Summary of Single-Shell Tank Waste Characterization: 1985 to 1987. WHC-EP-0075, Westinghouse Hanford Company, Richland, Washington.

Remund, K. M. et al. 1994. Tank Characterization Report for Single-Shell Tank B-111. PNL-10099, Pacific Northwest Laboratory, Richland, Washington.

Schneider, K. J. 1951. Flow Sheets and Flow Diagrams of Precipitation Separations Process. HW-23043, General Electric Company, Hanford Atomic Works, Richland, Washington. 
Simpson, B. C., G. L. Borsheim, and L. Jensen. 1993a. Tank Characterization Report for SingleShell Tank C-109. WHC-EP-0668, Westinghouse Hanford Company, Richland, Washington.

Simpson, B. C., G. L. Borsheim, and L. Jensen. 1993b. Tank Characterization Report for SingleShell Tank C-112. WHC-EP-0640 Rev. 1, Westinghouse Hanford Company, Richland, Washington.

Winters, W. I., L. Jensen, L. M. Sasaki, R. L. Weiss, J. F. Keller, A. J. Schmidt, and M. G.

Woodruff. 1989. Waste Characterization Plan for Hanford Site Single-Shell Tanks. WHC-EP-0210 Rev. 0, Westinghouse Hanford Company, Richland, Washington.

Winters, W. I., L. Jensen, L. M. Sasaki, R. L. Weiss, J. F. Keller, A. J. Schmidt, and M. G.

Woodruff. 1990. Waste Characterization Plan for Hanford Site Single-Shell Tanks. WHC-EP-0210 Rev. 1, Westinghouse Hanford Company, Richland, Washington. 
Appendices 


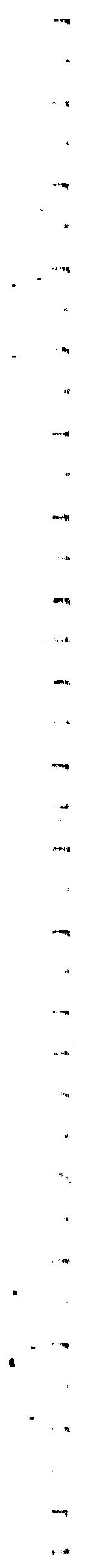


Appendix A

Sort on Radioactive Waste Type (SORWT)

Model Results 



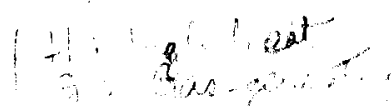

Sort on Radioactive Waste Type (SORWT) Model Results

\begin{tabular}{|c|c|c|c|c|c|c|c|c|c|c|c|}
\hline $\begin{array}{c}\text { SORWT } \\
\text { Group } \\
\end{array}$ & Tank No. & $\begin{array}{c}\text { Primary } \\
\text { Waste } \\
\text { Type } \\
\end{array}$ & $\begin{array}{c}\text { Secondary } \\
\text { Waste Type }\end{array}$ & $\begin{array}{c}\text { Tertiary } \\
\text { Waste } \\
\text { Type } \\
\end{array}$ & $\begin{array}{c}\text { Other } \\
\text { Waste } \\
\text { Type } \\
\end{array}$ & $\begin{array}{c}\text { Watch } \\
\text { List Status }\end{array}$ & $\begin{array}{c}\text { Volumé } \\
\text { of } \\
\text { Saltcake } \\
\text { (Kgal) }\end{array}$ & $\begin{array}{c}\begin{array}{c}\text { Volume } \\
\text { of Sludge } \\
\text { (Kgal) }\end{array} \\
\end{array}$ & $\begin{array}{c}\text { Volume of } \\
\text { Supernate } \\
\text { (Kgal) }\end{array}$ & $\begin{array}{c}\text { Volume } \\
\text { Interstitial } \\
\text { Liquid } \\
\text { (Kgal) } \\
\end{array}$ & $\begin{array}{c}\text { Total } \\
\text { Waste } \\
\text { Volume } \\
\text { (Kgal) } \\
\end{array}$ \\
\hline I & S-101 & $\mathbf{R}$ & EB & IX & MIX & $\mathbf{N}$ & 171 & 244 & 12 & 84 & 427 \\
\hline I & S-102 & $\mathbf{R}$ & EB & DSSF & & OG & 545 & 4 & 0 & 230 & 549 \\
\hline I & S-103 & $\mathbf{R}$ & EB & DSSF & & $\mathrm{N}$ & 221 & 10 & 17 & 85 & 248 \\
\hline I & S-105 & $\mathbf{R}$ & EB & & & $\mathbf{N}$ & 454 & 2 & 0 & 35 & 456 \\
\hline I & S-106 & $\mathbf{R}$ & EB & & & $\mathrm{N}$ & 447 & 28 & 4 & 186 & 479 \\
\hline I & S-107 & $\mathbf{R}$ & EB & $\mathrm{CW}$ & IX-MIX & $\mathrm{N}$ & 69 & 293 & 14 & 45 & 376 \\
\hline I & S-108 & $\mathbf{R}$ & EB & & & $\mathbf{N}$ & 600 & 4 & 0 & 127 & 604 \\
\hline I & S-109 & $\mathbf{R}$ & EB & & & $\mathbf{N}$ & 555 & 13 & 0 & 141 & 568 \\
\hline I & S-110 & $\mathbf{R}$ & EB & MIX & & $\mathrm{N}$ & 259 & 131 & 0 & 110 & 390 \\
\hline I & S-111 & $\mathbf{R}$ & EB & & & G & 447 & 139 & 10 & 195 & 596 \\
\hline I & S-112 & $\mathbf{R}$ & EB & & & G & 518 & 5 & 0 & 110 & 523 \\
\hline I & SX-101 & $\mathbf{R}$ & EB & RIX & & $\mathrm{G}$ & 343 & 112 & 1 & 145 & 456 \\
\hline I & SX-102 & $\mathbf{R}$ & EB & $\mathrm{RIX}$ & & $\mathrm{G}$ & 426 & 117 & 0 & 183 & 543 \\
\hline I & SX-103 & $\mathbf{R}$ & EB & $\mathrm{CW}$ & oww & G & 536 & 115 & 1 & 232 & 652 \\
\hline I & SX-104 & $\mathbf{R}$ & EB & RIX & & $\mathrm{G}$ & 478 & 136 & 0 & 201 & 614 \\
\hline I & SX-105 & $\mathbf{R}$ & EB & $\mathrm{RLX}$ & HLO & $\mathbf{G}$ & 610 & 73 & 0 & 261 & 683 \\
\hline I & SX-106 & $\mathbf{R}$ & EB & $\mathrm{RIX}$ & HLO-MX & OG & 465 & 12 & 61 & 194 & 538 \\
\hline I & TX-102 & $\mathbf{R}$ & EB & MIX & & $\mathbf{N}$ & 217 & 0 & 0 & 22 & 217 \\
\hline I & TX-104 & $\mathbf{R}$ & $\mathrm{EB}$ & MIX & & $\mathrm{N}$ & 64 & 0 & 1 & 14 & 65 \\
\hline I & TX-105 & $\mathbf{R}$ & EB & MIX & & 0 & 609 & 0 & 0 & 20 & 609 \\
\hline I & TX-106 & $\mathbf{R}$ & EB & MIX & & $\mathrm{N}$ & 453 & 0 & 0 & 10 & 453 \\
\hline I & TX-107 & $\mathbf{R}$ & EB & & & $\mathrm{N}$ & 35 & 0 & 1 & 1 & 36 \\
\hline \multicolumn{3}{|c|}{ Group I Subtotal } & & 22 Tanks & & & 8,522 & 1,438 & 122 & 2,631 & 10,082 \\
\hline II & B-105 & EB & $1 \mathrm{C}$ & $2 \mathrm{C}$ & & $\mathrm{N}$ & 266 & 40 & 0 & 23 & 306 \\
\hline II & TX-109 & EB & $1 \mathrm{C}$ & TBP & & $\mathrm{N}$ & 384 & 0 & 0 & 10 & 384 \\
\hline II & TX-110 & EB & $1 \mathrm{C}$ & TBP & & $\mathbf{N}$ & 462 & 0 & 0 & 15 & 462 \\
\hline II & TX-111 & EB & $1 \mathrm{C}$ & TBP & & $\mathrm{N}$ & 370 & 0 & 0 & 9 & 370 \\
\hline II & TX-112 & EB & $1 \mathrm{C}$ & & & $\mathrm{N}$ & 649 & 0 & 0 & 24 & 649 \\
\hline II & TX-113 & EB & $1 \mathrm{C}$ & & & $\mathrm{N}$ & 607 & 0 & 0 & 16 & 607 \\
\hline II & TX-114 & EB & $1 \mathrm{C}$ & & & $\mathrm{N}$ & 535 & 0 & 0 & 15 & 535 \\
\hline II & TX-116 & EB & $1 \mathrm{C}$ & & & $\mathrm{N}$ & 631 & 0 & 0 & 23 & 631 \\
\hline ПI & TX-117 & EB & $1 \mathrm{C}$ & & & $\mathbf{N}$ & 626 & 0 & 0 & 8 & 626 \\
\hline II & TY-102 & EB & $1 \mathrm{C}$ & $\mathrm{MIX}$ & & $\mathrm{N}$ & 64 & 0 & 0 & 14 & 64 \\
\hline \multicolumn{3}{|c|}{ Group II Subtotal } & & 10 Tanks & & & 4,594 & 40 & 0 & 157 & 4,634 \\
\hline III & BY-101 & TBP-F & EB-ITS & $\mathrm{CW}$ & $1 \mathrm{C}$ & F & 278 & 109 & 0 & 5 & 387 \\
\hline III & BY-103 & TBP-F & EB-ITS & $P$ & CW-OW & F & 395 & 5 & 0 & 160 & 400 \\
\hline III & BY-104 & TBP-F & EB-ITS & $\mathrm{CW}$ & $\mathrm{IX}$ & F & 366 & 40 & 0 & 18 & 406 \\
\hline III & BY -105 & TBP-F & EB-ITS & $\mathrm{CW}$ & & F & 459 & 44 & 0 & 192 & 503 \\
\hline III & BY-106 & TBP-F & EB-ITS & $\mathrm{CW}$ & & F & 547 & 95 & 0 & 235 & 642 \\
\hline III & BY-107 & TBP-F & EB-ITS & $\mathrm{CW}$ & & F & 206 & 60 & 0 & 25 & 266 \\
\hline III & BY-108 & TBP-F & EB-ITS & $1 \mathrm{C}$ & $\mathrm{CW}$ & F & 74 & 154 & 0 & 9 & 228 \\
\hline III & BY-110 & TBP-F & EB-ITS & $1 \mathrm{C}$ & $\mathrm{CW}$ & $\mathrm{F}$ & 295 & 103 & 0 & 9 & 398 \\
\hline ШI & BY-111 & TBP-F & EB-ITS & owW & $\mathrm{CW}$ & F & 438 & 21 & 0 & 0 & 459 \\
\hline III & BY-112 & TBP-F & EB-ITS & $\mathrm{CW}$ & & F & 286 & 5 & 0 & 8 & 291 \\
\hline \multicolumn{3}{|c|}{ Group III Subtotal } & & 10 Tanks & & & 3,344 & 636 & 0 & 661 & 3,980 \\
\hline
\end{tabular}




\begin{tabular}{|c|c|c|c|c|c|c|c|c|c|c|c|c|}
\hline $\begin{array}{c}\text { SORWT } \\
\text { Group }\end{array}$ & Tank No. & $\begin{array}{l}\text { Primary } \\
\text { Waste } \\
\text { Type } \\
\end{array}$ & $\begin{array}{c}\text { Secondary } \\
\text { Waste Type }\end{array}$ & $\begin{array}{c}\text { dioactive } \\
\text { Tertiary } \\
\text { Waste } \\
\text { Type } \\
\end{array}$ & $\begin{array}{c}\text { Waste } \\
\text { Other } \\
\text { Waste } \\
\text { Type }\end{array}$ & $\begin{array}{c}\text { Watch } \\
\text { List Status }\end{array}$ & $\begin{array}{c}\text { PRWT) } \\
\text { Volume } \\
\text { of } \\
\text { Saltcake } \\
\text { (Kgal) }\end{array}$ & $\begin{array}{c}\text { Model R } \\
\text { Volume } \\
\text { of Sludge } \\
\text { (Kgal) }\end{array}$ & $\begin{array}{l}\text { esults } \\
\text { Volume of } \\
\text { Supernate } \\
\text { (Kgal) }\end{array}$ & $\begin{array}{c}\text { Volume } \\
\text { Interstitial } \\
\text { Liquid } \\
\text { (Kgal) } \\
\end{array}$ & $\begin{array}{c}\text { Total } \\
\text { Waste } \\
\text { Volume } \\
\text { (Kgal) }\end{array}$ & \\
\hline IV & S-104 & $\mathbf{R}$ & & & & $\mathbf{N}$ & 0 & 293 & 1 & 28 & 294 & \\
\hline IV & SX-107 & $\mathbf{R}$ & & & & $\mathbf{H}$ & 0 & 104 & 0 & 5 & 104 & . \\
\hline IV & $\underline{\mathrm{SX}-108}$ & $\mathrm{R}$ & & & & $\mathbf{H}$ & 0 & 87 & 0 & 5 & 87 & \\
\hline IV & SX-109 & $\mathbf{R}$ & & & & GH & 0 & 250 & 0 & 10 & 250 & \\
\hline IV & $\mathrm{SX}-112$ & $\mathbf{R}$ & & & & $\mathbf{H}$ & 0 & 92 & 0 & 3 & 92 & \\
\hline IV & SX-115 & $\mathbf{R}$ & & & & $\mathbf{N}$ & 0 & 12 & 0 & 0 & 12 & \\
\hline IV & SX-110 & $\mathbf{R}$ & & & & $\mathbf{H}$ & 0 & 62 & 0 & 0 & 62 & \\
\hline IV & SX-111 & $\mathbf{R}$ & & & & $\mathbf{H}$ & 0 & 125 & 0 & 7 & 125 & . \\
\hline IV & SX-114 & $\mathbf{R}$ & & & & $\mathbf{H}$ & 0 & 181 & 0 & 14 & 181 & \\
\hline IV & U-101 & $\mathbf{R}$ & & & & $\mathbf{N}$ & 0 & 22 & 3 & 0 & 25 & \\
\hline \multicolumn{3}{|c|}{ Group IV Subtotal } & & 10 Tanks & & & 0 & 1,228 & 4 & 72 & 1,232 & - \\
\hline V & $\mathrm{BX}-101$ & TBP & $\mathrm{CW}$ & $\mathrm{BL}$ & IX & $\mathrm{N}$ & 0 & 42 & 1 & 0 & 43 & \\
\hline $\mathrm{V}$ & BX-102 & TBP & $\mathrm{CW}$ & $\mathrm{BL}$ & DIA & F & 0 & 96 & 0 & 4 & 96 & \\
\hline V & BX-103 & TBP & $\mathrm{CW}$ & oww & $\mathrm{MIX}$ & $\mathrm{N}$ & 0 & 62 & 4 & 0 & 66 & \\
\hline V & BX-104 & TBP & $\mathrm{CW}$ & IX & $\mathbf{R}$ & $\mathbf{N}$ & 0 & 96 & 3 & 30 & 99 & \\
\hline V & BX-105 & TBP & $\mathrm{CW}$ & IX & EB & $\mathbf{N}$ & 3 & 43 & 5 & 6 & 51 & \\
\hline V & $\mathrm{BX}-106$ & TBP & $\mathrm{CW}$ & EB-IX & $\mathrm{BL}$ & $\mathbf{F}$ & 0 & 31 & 15 & 0 & 46 & \\
\hline V & BX-108 & TBP & $\mathrm{CW}$ & $1 \mathrm{C}$ & $\mathrm{IX}$ & $\mathbf{N}$ & 0 & 26 & 0 & 1 & 26 & \\
\hline V & BX-109 & TBP & $\mathrm{CW}$ & $1 \mathrm{C}$ & $\mathbf{D X}$ & $\mathrm{N}$ & 0 & 193 & 0 & 13 & 193 & \\
\hline $\mathrm{V}$ & C-101 & TBP & $\mathrm{CW}$ & $\mathbf{P}$ & oww & $\mathbf{N}$ & 0 & 88 & 0 & 3 & 88 & \\
\hline \multicolumn{3}{|c|}{ Group V Subtotal } & & 9 Tanks & & & 3 & 677 & 28 & 57 & 708 & \\
\hline VI & B-101 & $\mathrm{EB}$ & $\mathrm{CW}$ & $\mathrm{BL}$ & & $\mathbf{N}$ & 0 & 113 & 0 & 6 & 113 & \\
\hline VI & B-102 & EB & $\mathrm{CW}$ & $\mathrm{BL}$ & $\mathbf{L X}$ & $\mathrm{N}$ & 10 & 18 & 4 & 0 & 32 & \\
\hline VI & B-103 & $\mathrm{EB}$ & $\mathrm{CW}$ & $\mathrm{IX}$ & $\mathrm{MIX}$ & 0 & 0 & 59 & 0 & 0 & 59 & \\
\hline VI & $\mathrm{TX}-118$ & EB & $\mathrm{CW}$ & PNF & & FO & 347 & 0 & 0 & 27 & 347 & \\
\hline VI & $\mathrm{U}-105$ & EB & $\mathrm{cW}$ & $\mathbf{R}$ & & G & 349 & 32 & 37 & 142 & 418 & \\
\hline VI & U-107 & EB & $\mathrm{CW}$ & $\mathrm{MIX}$ & & 0 & 360 & 15 & 31 & 147 & 406 & \\
\hline VI & U-108 & EB & $\mathrm{CW}$ & $\mathrm{MTX}$ & & G & 415 & 29 & 24 & 172 & 468 & \\
\hline VI & U-109 & EB & $\mathrm{CW}$ & $\mathbf{R}$ & & G & 396 & 48 & 19 & 163 & 463 & \\
\hline \multicolumn{3}{|c|}{ Group VI Subtotal } & & 8 Tanks & & & 1,877 & 314 & 115 & 657 & 2,306 & \\
\hline VII & B-201 & 224 & & & & $\mathrm{~N}$ & 0 & 28 & 1 & 3 & 29 & \\
\hline VII & B-202 & 224 & & & & $\mathrm{~N}$ & 0 & 27 & 0 & 3 & 27 & \\
\hline vil & B-203 & 224 & & & & $\mathbf{N}$ & 0 & 50 & 1 & 5 & 51 & \\
\hline VII & B-204 & 224 & & & & $\mathbf{N}$ & 0 & 49 & 1 & 5 & 50 & \\
\hline VII & $\mathrm{T}-201$ & 224 & & & & $\mathbf{N}$ & 0 & 28 & 1 & 3 & 29 & \\
\hline VII & $\mathrm{T}-202$ & 224 & & & & $\mathbf{N}$ & 0 & 21 & 0 & 2 & 21 & \\
\hline VII & $\mathrm{T}-203$ & 224 & & & & $\mathrm{~N}$ & 0 & 35 & 0 & 4 & 35 & \\
\hline VII & $\mathrm{T}-204$ & 224 & & & & $\mathbf{N}$ & 0 & 38 & 0 & 4 & 38 & • \\
\hline \multicolumn{3}{|c|}{ Group VII Subtotal } & & 8 Tanks & & & 0 & 276 & 4 & 29 & 280 & i \\
\hline
\end{tabular}


Sort on Radioactive Waste Type (SORWT) Model Results

\begin{tabular}{|c|c|c|c|c|c|c|c|c|c|c|c|}
\hline $\begin{array}{c}\text { SORWT } \\
\text { Group }\end{array}$ & Tank No. & $\begin{array}{l}\text { Primary } \\
\text { Waste } \\
\text { Type } \\
\end{array}$ & $\begin{array}{c}\text { Secondary } \\
\text { Waste Type }\end{array}$ & $\begin{array}{c}\text { Tertiary } \\
\text { Waste } \\
\text { Type } \\
\end{array}$ & $\begin{array}{l}\text { Other } \\
\text { Waste } \\
\text { Type }\end{array}$ & $\begin{array}{c}\text { Watch } \\
\text { List Status } \\
\end{array}$ & $\begin{array}{c}\text { Volume } \\
\text { of } \\
\text { Saltcake } \\
\text { (Kgal) }\end{array}$ & $\begin{array}{c}\text { Volume } \\
\text { of Sludge } \\
\text { (Kgal) }\end{array}$ & $\begin{array}{c}\text { Volume of } \\
\text { Supernate } \\
\text { (Kgal) }\end{array}$ & $\begin{array}{c}\text { Volume } \\
\text { Interstitial } \\
\text { Liquid } \\
\text { (Kgal) } \\
\end{array}$ & $\begin{array}{c}\text { Total } \\
\text { Waste } \\
\text { Volume } \\
\text { (Kgal) } \\
\end{array}$ \\
\hline VIII & B-107 & $1 \mathrm{C}$ & $\mathrm{EB}$ & $\mathrm{CW}$ & TBP & $\mathbf{N}$ & 0 & 164 & 1 & 12 & 165 \\
\hline VIII & B-108 & $1 \mathrm{C}$ & EB & $\mathrm{CW}$ & LX-TBP & $\mathbf{N}$ & 0 & 94 & 0 & 4 & 94 \\
\hline VIII & B-109 & $1 \mathrm{C}$ & EB & CW & $\mathbf{L X}$ & $\mathbf{N}$ & 0 & 127 & 0 & 8 & 127 \\
\hline VIII & $\mathrm{BX}-110$ & $1 \mathrm{C}$ & EB-ITS & $\mathrm{CW}$ & IX & F & 9 & 189 & 0 & 15 & 198 \\
\hline VIII & BX-111 & $1 \mathrm{C}$ & EB-ITS & $\mathrm{CW}$ & IX & F & 143 & 68 & 0 & 0 & 211 \\
\hline VIII & $\mathrm{BX}-112$ & $1 \mathrm{C}$ & EB & $\mathrm{CW}$ & $\mathrm{IX}$ & $\mathrm{N}$ & 0 & 164 & 1 & 7 & 165 \\
\hline \multicolumn{3}{|c|}{ Group VIII Subtotal } & & 6 Tanks & & & 152 & 806 & 2 & 46 & 960 \\
\hline $\mathrm{IX}$ & TX-115 & EB & $\mathbf{R}$ & $\mathrm{CW}$ & DW & $\mathrm{N}$ & 640 & $\mathbf{0}$ & 0 & 19 & 640 \\
\hline $\mathbf{I X}$ & U-102 & EB & $\mathbf{R}$ & & & $\mathbf{N}$ & 313 & 43 & 18 & 126 & 374 \\
\hline IX & U-103 & EB & $\mathbf{R}$ & MIX & & $\mathbf{G}$ & 423 & 32 & 13 & 176 & 468 \\
\hline LX & U-106 & EB & $\mathbf{R}$ & $\mathrm{BL}$ & PL & 0 & 185 & 26 & 15 & 68 & 226 \\
\hline DX & U-111 & EB & $\mathbf{R}$ & $1 \mathrm{C}$ & & 0 & 303 & 26 & 0 & 122 & 329 \\
\hline \multicolumn{3}{|c|}{ Group IX Subtotal } & & 5 Tanks & & & 1,864 & 127 & 46 & 511 & 2,037 \\
\hline $\mathrm{x}$ & C-107 & $1 \mathrm{C}$ & $\mathrm{CW}$ & SRS & & $\mathrm{N}$ & 0 & 275 & 0 & 26 & 275 \\
\hline $\mathrm{X}$ & T-105 & $1 \mathrm{C}$ & $\mathrm{CW}$ & $2 \mathrm{C}$ & BL-DX & $\mathrm{N}$ & $\mathbf{0}$ & 98 & 0 & 23 & 98 \\
\hline $\mathrm{X}$ & T-106 & $1 \mathrm{C}$ & $\mathrm{CW}$ & $2 \mathrm{C}$ & MIX & $\mathrm{N}$ & $\mathbf{0}$ & 19 & 2 & 0 & 21 \\
\hline $\mathrm{X}$ & T-107 & $1 \mathrm{C}$ & $\mathrm{CW}^{-}$ & TBP. & & F & 0 & 171 & 9 & 13 & 180 \\
\hline $\mathrm{x}$ & $\mathrm{U}-110$ & $1 \mathrm{C}$ & $\mathrm{CW}$ & $\mathbf{R}$ & LW & $\mathrm{N}$ & 0 & 186 & 0 & 15 & 186 \\
\hline \multicolumn{3}{|c|}{ Group X Subtotal } & & 5 Tanks & & & 0 & 749 & 11 & 77 & 760 \\
\hline $\mathrm{XI}$ & $A-101$ & DSSF & NCPLX & EVAP & & G & 950 & 3 & 0 & 413 & 953 \\
\hline $\mathrm{XI}$ & A-1.02 & DSSF & NCPLX & EVAP & & $\mathrm{N}$ & 22 & 15 & 4 & 2 & 41 \\
\hline XI & A-103 & DSSF & NCPLX & EVAP & & $\mathrm{N}$ & 0 & 366 & 5 & 15 & 371 \\
\hline $\mathrm{XI}$ & $A X-101$ & DSSF & NCPLX & EVAP & & G & 745 & 3 & 0 & 320 & 748 \\
\hline \multicolumn{3}{|c|}{ Group XI Subtotal } & & 4 Tanks & & & 1,717 & 387 & 9 & 750 & 2,113 \\
\hline XII & B-106 & $1 \mathrm{C}$ & TBP & HLO & MIX & $\mathrm{N}$ & 0 & 116 & 1 & 6 & 117 \\
\hline XII & BX-107 & $1 \mathrm{C}$ & TBP & $\mathrm{CW}$ & DX & $\mathrm{N}$ & 0 & 344 & 1 & 29 & 345 \\
\hline $\mathrm{XII}$ & C-110 & $1 \mathrm{C}$ & TBP & oww & EB-IX & $\mathrm{N}$ & 0 & 187 & 0 & 7 & 187 \\
\hline XII & $\mathrm{T}-108$ & $1 \mathrm{C}$ & TBP & EB & $\mathrm{HLO}$ & $\mathrm{N}$ & 0 & 44 & 0 & 0 & 44 \\
\hline \multicolumn{3}{|c|}{ Group XII Subtotal } & & 4 Tanks & & & 0 & 691 & 2 & 42 & 693 \\
\hline XIII & C. -108 & TBP-F & $1 \mathrm{C}$ & $\mathrm{CW}$ & oww & $\mathrm{F}$ & 0 & 66 & 0 & 0 & 66 \\
\hline XIII & C- 109 & TBP-F & $1 \mathrm{C}$ & $\mathrm{cW}$ & IX & $\mathrm{F}$ & 0 & 62 & 4 & 0 & 66 \\
\hline XIII & C-111 & TBP-F & $1 \mathrm{C}$ & $\mathrm{cW}$ & $\mathrm{HS}$ & $\mathrm{F}$ & 0 & 57 & 0 & 0 & 57 \\
\hline XIII & C-112 & TBP-F & $1 C$ & $\mathrm{CW}$ & IX & F & 0 & 104 & 0 & 32 & 104 \\
\hline \multicolumn{3}{|c|}{ p XIII Subtotal } & & 4 Tanks & & & 0 & 289 & 4 & 32 & 293 \\
\hline
\end{tabular}




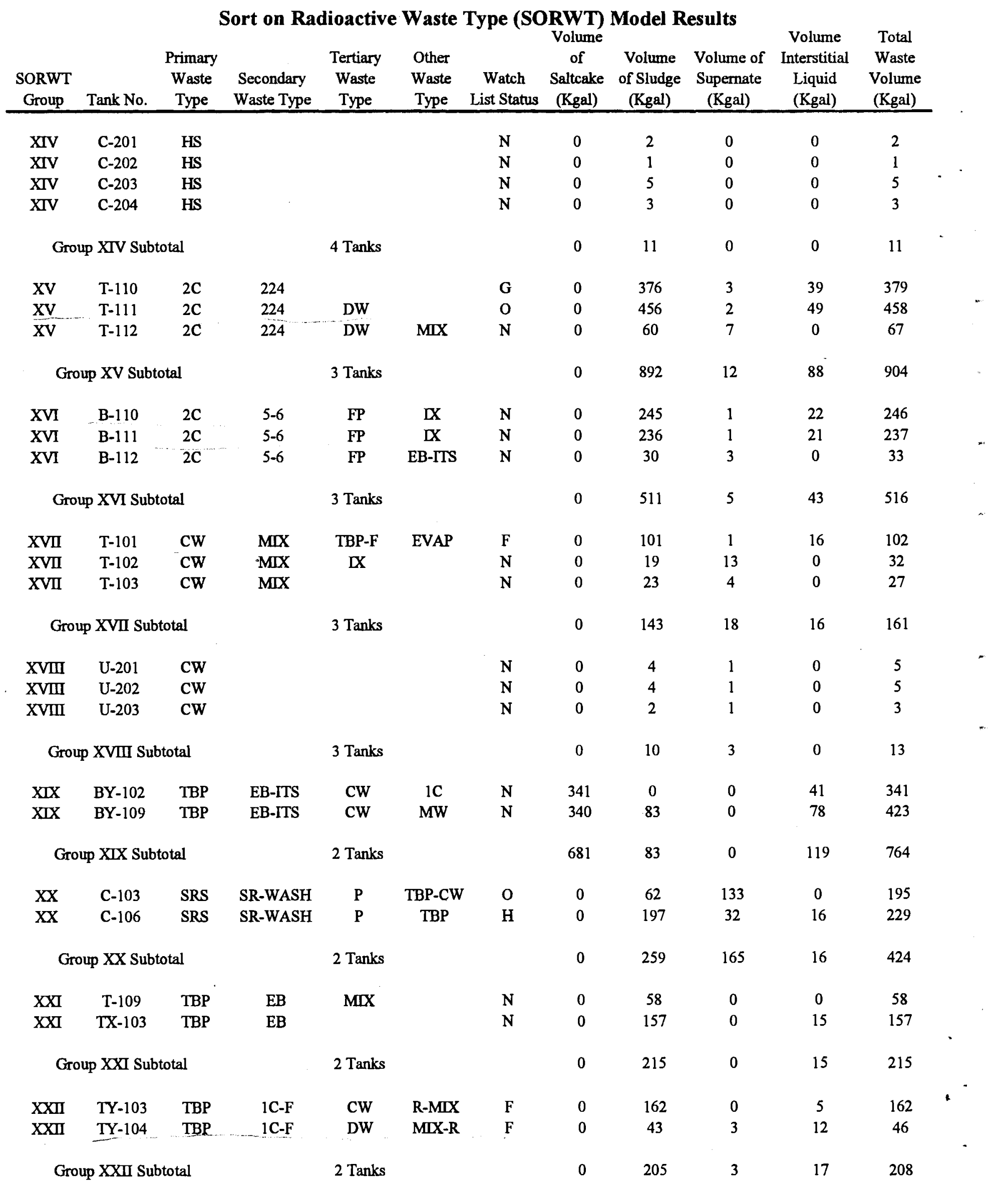


Sort on Radioactive Waste Type (SORWT) Model Results

\begin{tabular}{|c|c|c|c|c|c|c|c|c|c|c|c|}
\hline $\begin{array}{l}\text { SORWT } \\
\text { Group }\end{array}$ & Tank No. & $\begin{array}{c}\text { Primary } \\
\text { Waste } \\
\text { Type } \\
\end{array}$ & $\begin{array}{c}\text { Secondary } \\
\text { Waste Type } \\
\end{array}$ & $\begin{array}{c}\text { Tertiary } \\
\text { Waste } \\
\text { Type } \\
\end{array}$ & $\begin{array}{c}\text { Other } \\
\text { Waste } \\
\text { Type } \\
\end{array}$ & $\begin{array}{c}\text { Watch } \\
\text { List Status } \\
\end{array}$ & $\begin{array}{c}\text { Volume } \\
\text { of } \\
\text { Saltcake } \\
\text { (Kgal) } \\
\end{array}$ & $\begin{array}{c}\text { Volume } \\
\text { of Sludge } \\
\text { (Kgal) }\end{array}$ & $\begin{array}{c}\text { Volume of } \\
\text { Supernate } \\
\text { (Kgal) }\end{array}$ & $\begin{array}{c}\text { Volume } \\
\text { Interstitial } \\
\text { Liquid } \\
\text { (Kgal) } \\
\end{array}$ & $\begin{array}{c}\text { Total } \\
\text { Waste } \\
\text { Volume } \\
\text { (Kgal) } \\
\end{array}$ \\
\hline XXIII & AX-102 & CCPLX & DSSF & EVAP & & $\mathrm{N}$ & 29 & 7 & 3 & 14 & 39 \\
\hline XXIII & AX-103 & CCPLX & DSSF & EVAP & & G & 110 & 2 & 0 & 36 & 112 \\
\hline \multicolumn{3}{|c|}{ Group XXIII Subtotal } & & 2 Tanks & & & 139 & 9 & 3 & 50 & 151 \\
\hline XXIV & SX-113 & $\mathbf{R}$ & DIA & & & $\mathbf{N}$ & 0 & 26 & 0 & 0 & 26 \\
\hline XXIV & U-104 & $\mathbf{R}$ & DIA & & & $\mathbf{N}$ & 0 & 122 & 0 & 7 & 122 \\
\hline \multicolumn{3}{|c|}{ Group XXIV Subtotal } & & 2 Tanks & & & 0 & 148 & 0 & 7 & 148 \\
\hline XXVA & A-104 & SLUICE & $\mathbf{P}$ & $\mathrm{H} 20$ & $\mathrm{~B}$ & $\mathbf{H}$ & 0 & 28 & 0 & 0 & 28 \\
\hline XXVB & A-105 & $\mathbf{P}$ & $\mathrm{LX}$ & & & H & 0 & 19 & 0 & 4 & 19 \\
\hline $\mathrm{XXVC}$ & A-106 & CCPLX & NCPLX & EVAP & B & $\mathbf{N}$ & 0 & 125 & 0 & 7 & 125 \\
\hline XXVD & AX-104 & EVAP & NCPLX & $P$ & & $\mathbf{N}$ & 0 & 7 & 0 & 0 & 7 \\
\hline XXVE & B-104 & $2 \mathrm{C}$ & EB & TBP & $1 \mathrm{C}$ & $\mathbf{N}$ & 69 & 301 & 1 & 46 & 371 \\
\hline XXVF & C-102 & $\mathrm{CW}$ & TBP & owW & & $\mathbf{N}$ & 0 & 423 & 0 & 37 & 423 \\
\hline XXVG & C-104 & $\mathrm{CW}$ & OWW & SR-WAS & SRS & $\mathrm{MXN}$ & 0 & 295 & 0 & 11 & 295 \\
\hline XXVH & C-105 & TBP & SR-WASH & $\mathrm{CW}$ & $\mathbf{P}$ & $\mathbf{H}$ & 0 & 150 & 0 & 11. & 150 \\
\hline XXVI & $T-104$ & $1 \mathrm{C}$ & & & & $\mathbf{N}$ & 0 & 442 & 3 & 47 & 445 \\
\hline $\mathrm{XXVJ}$ & TX-101 & $\mathbf{R}$ & $\mathrm{MIX}$ & MIX & & $\mathbf{N}$ & 0 & 84 & 3 & 2 & 87 \\
\hline XXVK & TX-108 & EB & DW & & & $\mathbf{N}$ & 134 & 0 & 0 & 0 & 134 \\
\hline XXVL & TY-101 & $1 \mathrm{C}-\mathrm{F}$ & EB & TBP & $\mathbf{R}$ & $\mathbf{F}$ & 0 & 118 & 0 & 0 & 118 \\
\hline XXVM & TY-105 & TBP & & & & $\mathbf{N}$ & 0 & 231 & 0 & 0 & 231 \\
\hline$X X V N$ & TY-106 & TBP & DIA & & & $\mathbf{N}$ & 0 & 17 & 0 & 0 & 17 \\
\hline XXVO & $\mathrm{U}-204$ & $\mathbf{R}$ & $2 \mathrm{C}$ & $\mathrm{CW}$ & & $\mathbf{N}$ & 0 & 2 & 1 & 0 & 3 \\
\hline$X X V P$ & U-112 & UK & & & & $\mathbf{N}$ & 0 & 45 & 4 & 0 & 49 \\
\hline \multicolumn{3}{|c|}{ Ungrouped Subtotal } & & 16 Tanks & & & 203 & 2,287 & 12 & 165 & 2,502 \\
\hline \multicolumn{3}{|c|}{ Total Inventory } & & & & & 23,096 & 12,431 & 568 & 6,258 & 36,095 \\
\hline
\end{tabular}


Sort on Radioactive Waste Type (SORWT) Model Results

\begin{tabular}{|c|c|c|c|c|c|c|c|c|c|c|c|}
\hline $\begin{array}{c}\text { SORWT } \\
\text { Group }\end{array}$ & Tank No. & $\begin{array}{c}\text { Primary } \\
\text { Waste } \\
\text { Type } \\
\end{array}$ & $\begin{array}{c}\text { Secondary } \\
\text { Waste Type } \\
\end{array}$ & $\begin{array}{c}\text { Tertiary } \\
\text { Waste } \\
\text { Type }\end{array}$ & $\begin{array}{l}\text { Other } \\
\text { Waste } \\
\text { Type } \\
\end{array}$ & $\begin{array}{c}\text { Watch } \\
\text { List Status } \\
\end{array}$ & $\begin{array}{l}\% \text { of } \\
\text { Total } \\
\text { Saltcake } \\
\text { Volume } \\
\end{array}$ & $\begin{array}{c}\% \text { of } \\
\text { Total } \\
\text { Sludge } \\
\text { Volume } \\
\end{array}$ & $\begin{array}{c}\% \text { of Total } \\
\text { Supernate } \\
\text { Volume } \\
\end{array}$ & $\begin{array}{c}\% \text { of Total } \\
\text { Interstitial } \\
\text { Liquid } \\
\end{array}$ & $\begin{array}{c}\% \text { of } \\
\text { Total } \\
\text { Waste } \\
\text { Volume } \\
\end{array}$ \\
\hline I & S-101 & $\mathbf{R}$ & EB & IX & MIX & $\mathrm{N}$ & $0.74 \%$ & $1.96 \%$ & $2.11 \%$ & $1.34 \%$ & $1.18 \%$ \\
\hline I & S-102 & $\mathbf{R}$ & $\mathrm{EB}$ & DSSF & & OG & $2.36 \%$ & $0.03 \%$ & $0.00 \%$ & $3.68 \%$ & $1.52 \%$ \\
\hline I & S-103 & $\mathbf{R}$ & $\mathrm{EB}$ & DSSF & & $\mathbf{N}$ & $0.96 \%$ & $0.08 \%$ & $2.99 \%$ & $1.36 \%$ & $0.69 \%$. \\
\hline I & S-105 & $\mathbf{R}$ & $\mathrm{EB}$ & & & $\mathrm{N}$ & $1.97 \%$ & $0.02 \%$ & $0.00 \%$ & $0.56 \%$ & $1.26 \%$ \\
\hline I & S-106 & $\mathbf{R}$ & EB & & & $\mathbf{N}$ & $1.94 \%$ & $0.23 \%$ & $0.70 \%$ & $2.97 \%$ & $1.33 \%$ \\
\hline I & S-107 & $\mathbf{R}$ & EB & $\mathrm{CW}$ & DX-MIX & $\mathrm{N}$ & $0.30 \%$ & $2.36 \%$ & $2.46 \%$ & $0.72 \%$ & $1.04 \%$. \\
\hline I & S-108 & $\mathbf{R}$ & $\mathrm{EB}$ & & & $\mathbf{N}$ & $2.60 \%$ & $0.03 \%$ & $0.00 \%$ & $2.03 \%$ & $1.67 \%$ \\
\hline I & S-109 & $\mathbf{R}$ & $\mathrm{EB}$ & & & $\mathrm{N}$ & $2.40 \%$ & $0.10 \%$ & $0.00 \%$ & $2.25 \%$ & $1.57 \%$ \\
\hline I & S-110 & $\mathbf{R}$ & EB & MIX & & $\mathrm{N}$ & $1.12 \%$ & $1.05 \%$ & $0.00 \%$ & $1.76 \%$ & $1.08 \%$ \\
\hline I & S-111 & $\mathbf{R}$ & EB & & & $\mathrm{G}$ & $1.94 \%$ & $1.12 \%$ & $1.76 \%$ & $3.12 \%$ & $1.65 \%$ \\
\hline I & S-112 & $\mathbf{R}$ & EB & & & $G$ & $2.24 \%$ & $0.04 \%$ & $0.00 \%$ & $1.76 \%$ & $1.45 \%$ \\
\hline I & SX-101 & $\mathbf{R}$ & $\mathrm{EB}$ & RIX & & G & $1.49 \%$ & $0.90 \%$ & $0.18 \%$ & $2.32 \%$ & $1.26 \%$ \\
\hline I & SX-102 & $\mathbf{R}$ & EB & $\mathrm{RIX}$ & & G & $1.84 \%$ & $0.94 \%$ & $0.00 \%$ & $2.92 \%$ & $1.50 \%$ \\
\hline I & SX-103 & $\mathbf{R}$ & EB & $\mathrm{cW}$ & oww & $G$ & $2.32 \%$ & $0.93 \%$ & $0.18 \%$ & $3.71 \%$ & $1.81 \%$ \\
\hline I & SX-104 & $\mathbf{R}$ & EB & RIX & & $\mathrm{G}$ & $2.07 \%$ & $1.09 \%$ & $0.00 \%$ & $3.21 \%$ & $1.70 \%$ \\
\hline I & SX-105 & $\mathbf{R}$ & EB & $\mathrm{RIX}$ & HLO & $G$ & $2.64 \%$ & $0.59 \%$ & $0.00 \%$ & $4.17 \%$ & $1.89 \%$ \\
\hline I & SX-106 & $\mathbf{R}$ & EB & $\mathrm{RIX}$ & HLO-MX & OG & $2.01 \%$ & $0.10 \%$ & $10.74 \%$ & $3.10 \%$ & $1.49 \%$ \\
\hline I & TX-102 & $\mathbf{R}$ & EB & MIX & & $\mathrm{N}$ & $0.94 \%$ & $0.00 \%$ & $0.00 \%$ & $0.35 \%$ & $0.60 \%$ \\
\hline I & TX-104 & $\mathrm{R}$ & $\mathrm{EB}$ & MIX & & $\mathrm{N}$ & $0.28 \%$ & $0.00 \%$ & $0.18 \%$ & $0.22 \%$ & $0.18 \%$ \\
\hline I & TX-105 & $\mathbf{R}$ & $\mathrm{EB}$ & MIX & & 0 & $2.64 \%$ & $0.00 \%$ & $0.00 \%$ & $0.32 \%$ & $1.69 \%$ \\
\hline I & TX-106 & $\mathbf{R}$ & EB & $\mathrm{MLX}$ & & $\mathrm{N}$ & $1.96 \%$ & $0.00 \%$ & $0.00 \%$ & $0.16 \%$ & $1.26 \%$ \\
\hline I & TX-107 & $\mathbf{R}$ & EB & & & $\mathrm{N}$ & $0.15 \%$ & $0.00 \%$ & $0.18 \%$ & $0.02 \%$ & $0.10 \%$ \\
\hline \multicolumn{3}{|c|}{ Group I Subtotal } & & 22 Tanks & & & $36.90 \%$ & $11.57 \%$ & $21.48 \%$ & $42.04 \%$ & $27.93 \%$ \\
\hline II & B-105 & $\mathrm{EB}$ & $1 \mathrm{C}$ & $2 \mathrm{C}$ & & $\mathrm{N}$ & $1.15 \%$ & $0.32 \%$ & $0.00 \%$ & $0.37 \%$ & $0.85 \%$ \\
\hline II & TX-109 & EB & $1 \mathrm{C}$ & TBP & & $\mathrm{N}$ & $1.66 \%$ & $0.00 \%$ & $0.00 \%$ & $0.16 \%$ & $1.06 \%$ \\
\hline II & TX-110 & EB & $1 \mathrm{C}$ & TBP & & $\mathrm{N}$ & $2.00 \%$ & $0.00 \%$ & $0.00 \%$ & $0.24 \%$ & $1.28 \%$ \\
\hline II & TX-111 & EB & $1 \mathrm{C}$ & TBP & & $\mathrm{N}$ & $1.60 \%$ & $0.00 \%$ & $0.00 \%$ & $0.14 \%$ & $1.03 \%$ \\
\hline II & TX-112 & $\mathrm{EB}$ & $1 \mathrm{C}$ & & & $\mathbf{N}$ & $2.81 \%$ & $0.00 \%$ & $0.00 \%$ & $0.38 \%$ & $1.80 \%$ \\
\hline II & $\mathrm{TX}-113$ & $\mathrm{~EB}$ & $1 \mathrm{C}$ & & & $\mathbf{N}$ & $2.63 \%$ & $0.00 \%$ & $0.00 \%$ & $0.26 \%$ & $1.68 \%$ \\
\hline II & TX-114 & EB & $1 \mathrm{C}$ & & & N & $2.32 \%$ & $0.00 \%$ & $0.00 \%$ & $0.24 \%$ & $1.48 \%$ \\
\hline ПI & TX-116 & EB & $1 \mathrm{C}$ & & & $\mathrm{N}$ & $2.73 \%$ & $0.00 \%$ & $0.00 \%$ & $0.37 \%$ & $1.75 \%$ \\
\hline II & TX-117 & $\mathrm{EB}$ & $1 \mathrm{C}$ & & & $\mathbf{N}$ & $2.71 \%$ & $0.00 \%$ & $0.00 \%$ & $0.13 \%$ & $1.73 \%$ \\
\hline II & TY-102 & $\mathrm{EB}$ & $1 \mathrm{C}$ & MIX & & $\mathbf{N}$ & $0.28 \%$ & $.0 .00 \%$ & $0.00 \%$ & $0.22 \%$ & $0.18 \%$ \\
\hline \multicolumn{3}{|c|}{ Group II Subtotal } & & 10 Tanks & & & $19.89 \%$ & $0.32 \%$ & $0.00 \%$ & $2.51 \%$ & $12.84 \%$ \\
\hline III & BY-101 & TBP-F & EB-ITS & $\mathrm{CW}$ & $1 \mathrm{C}$ & F & $1.20 \%$ & $0.88 \%$ & $0.00 \%$ & $0.08 \%$ & $1.07 \%$ \\
\hline III & BY-103 & TBP-F & EB-ITS & $P$ & CW-OW & F & $1.71 \%$ & $0.04 \%$ & $0.00 \%$ & $2.56 \%$ & $1.11 \%$ \\
\hline III & BY-104 & TBP-F & EB-ITS & $\mathrm{cW}$ & IX & F & $1.58 \%$ & $0.32 \%$ & $0.00 \%$ & $0.29 \%$ & $1.12 \%$ \\
\hline III & BY-105 & TBP-F & EB-ITS & $\mathrm{CW}$ & & $\mathrm{F}$ & $1.99 \%$ & $0.35 \%$ & $0.00 \%$ & $3.07 \%$ & $1.39 \%$ \\
\hline III & BY-106 & TBP-F & EB-ITS & $\mathrm{CW}$ & & F & $2.37 \%$ & $0.76 \%$ & $0.00 \%$ & $3.76 \%$ & $1.78 \%$ \\
\hline III & BY-107 & TBP-F & EB-ITS & $\mathrm{CW}$ & & F & $0.89 \%$ & $0.48 \%$ & $0.00 \%$ & $0.40 \%$ & $0.74 \%$. \\
\hline III & BY-108 & TBP-F & EB-ITS & $1 \mathrm{C}$ & $\mathrm{CW}$ & F & $0.32 \%$ & $1.24 \%$ & $0.00 \%$ & $0.14 \%$ & $0.63 \%$ \\
\hline II & BY-110 & TBP-F & EB-ITS & $1 \mathrm{C}$ & $\mathrm{CW}$ & F & $1.28 \%$ & $0.83 \%$ & $0.00 \%$ & $0.14 \%$ & $1.10 \%$ \\
\hline III & BY-111 & TBP-F & EB-ITS & oww & $\mathrm{CW}$ & F & $1.90 \%$ & $0.17 \%$ & $0.00 \%$ & $0.00 \%$ & $1.27 \%$. \\
\hline III & BY-112 & TBP-F & EB-ITS & $\mathrm{CW}$ & & F & $1.24 \%$ & $0.04 \%$ & $0.00 \%$ & $0.13 \%$ & $0.81 \%$ \\
\hline \multicolumn{3}{|c|}{ Group III Subtotal } & & 10 Tanks & & & $14.48 \%$ & $5.12 \%$ & $0.00 \%$ & $10.56 \%$ & $11.03 \%$ \\
\hline
\end{tabular}




\section{Sort on Radioactive Waste Type (SORWT) Model Results}

\begin{tabular}{|c|c|c|c|c|c|c|c|c|c|c|c|}
\hline $\begin{array}{l}\text { SORWT } \\
\text { Group }\end{array}$ & Tank No. & $\begin{array}{l}\text { Primary } \\
\text { Waste } \\
\text { Type }\end{array}$ & $\begin{array}{l}\text { Secondary } \\
\text { Waste Type }\end{array}$ & $\begin{array}{l}\text { Tertiary } \\
\text { Waste } \\
\text { Type }\end{array}$ & $\begin{array}{l}\text { Other } \\
\text { Waste } \\
\text { Type }\end{array}$ & $\begin{array}{c}\text { Watch } \\
\text { List Status }\end{array}$ & $\begin{array}{l}\% \text { of } \\
\text { Total } \\
\text { Saltcake } \\
\text { Volume }\end{array}$ & $\begin{array}{l}\% \text { of } \\
\text { Total } \\
\text { Sludge } \\
\text { Volume }\end{array}$ & $\begin{array}{c}\% \text { of Total } \\
\text { Supernate } \\
\text { Volume }\end{array}$ & $\begin{array}{l}\% \text { of Total } \\
\text { Interstitial } \\
\text { Liquid }\end{array}$ & $\begin{array}{c}\% \text { of } \\
\text { Total } \\
\text { Waste } \\
\text { Volume } \\
\end{array}$ \\
\hline IV & S-104 & $\mathbf{R}$ & & & & $\mathrm{N}$ & $0.00 \%$ & $2.36 \%$ & $0.18 \%$ & $0.45 \%$ & $0.81 \%$ \\
\hline IV & SX-107 & $\mathbf{R}$ & & & & $\mathrm{H}$ & $0.00 \%$ & $0.84 \%$ & $0.00 \%$ & $0.08 \%$ & $0.29 \%$ \\
\hline IV & SX-108 & $\mathbf{R}$ & & & & $\mathrm{H}$ & $0.00 \%$ & $0.70 \%$ & $0.00 \%$ & $0.08 \%$ & $0.24 \%$ \\
\hline IV & SX-109 & $\mathbf{R}$ & & & & GH & $0.00 \%$ & $2.01 \%$ & $0.00 \%$ & $0.16 \%$ & $0.69 \%$ \\
\hline IV & SX-112 & $\mathbf{R}$ & & & & $\mathrm{H}$ & $0.00 \%$ & $0.74 \%$ & $0.00 \%$ & $0.05 \%$ & $0.25 \%$ \\
\hline IV & SX-115 & $\mathbf{R}$ & & & & $\mathrm{N}$ & $0.00 \%$ & $0.10 \%$ & $0.00 \%$ & $0.00 \%$ & $0.03 \%$ \\
\hline IV & SX-110 & $\mathbf{R}$ & & & & $\mathrm{H}$ & $0.00 \%$ & $0.50 \%$ & $0.00 \%$ & $0.00 \%$ & $0.17 \%$ \\
\hline IV & SX-111 & $\mathbf{R}$ & & & & $\mathrm{H}$ & $0.00 \%$ & $1.01 \%$ & $0.00 \%$ & $0.11 \%$ & $0.35 \%$ \\
\hline IV & SX-114 & $\mathbf{R}$ & & & & $\mathrm{H}$ & $0.00 \%$ & $1.46 \%$ & $0.00 \%$ & $0.22 \%$ & $0.50 \%$ \\
\hline IV & U-101 & $\mathbf{R}$ & & & & $\mathrm{N}$ & $0.00 \%$ & $0.18 \%$ & $0.53 \%$ & $0.00 \%$ & $0.07 \%$ \\
\hline \multicolumn{3}{|c|}{ Group IV Subtotal } & & 10 Tanks & & & $0.00 \%$ & $9.88 \%$ & $0.70 \%$ & $1.15 \%$ & $3.41 \%$ \\
\hline $\mathrm{v}$ & BX-101 & TBP & $\mathrm{CW}$ & $\mathrm{BL}$ & LX & $\mathrm{N}$ & $0.00 \%$ & $0.34 \%$ & $0.18 \%$ & $0.00 \%$ & $0.12 \%$ \\
\hline $\mathrm{v}$ & BX-102 & TBP & $\mathrm{CW}$ & $\mathrm{BL}$ & DIA & F & $0.00 \%$ & $0.77 \%$ & $0.00 \%$ & $0.06 \%$ & $0.27 \%$ \\
\hline $\mathrm{v}$ & BX-103 & TBP & $\mathrm{CW}$ & oww & $\mathrm{MIX}$ & $\mathrm{N}$ & $0.00 \%$ & $0.50 \%$ & $0.70 \%$ & $0.00 \%$ & $0.18 \%$ \\
\hline v & BX-104 & TBP & $\mathrm{CW}$ & LX & $\mathbf{R}$ & $\mathrm{N}$ & $0.00 \%$ & $0.77 \%$ & $0.53 \%$ & $0.48 \%$ & $0.27 \%$ \\
\hline V & BX-105 & TBP & $\mathrm{CW}$ & DX & EB & $\mathrm{N}$ & $0.01 \%$ & $0.35 \%$ & $0.88 \%$ & $0.10 \%$ & $0.14 \%$ \\
\hline V & BX-106 & TBP & $\mathrm{CW}$ & EB-DX & $\mathrm{BL}$ & F & $0.00 \%$ & $0.25 \%$ & $2.64 \%$ & $0.00 \%$ & $0.13 \%$ \\
\hline V & BX-108 & TBP & $\mathrm{CW}$ & $1 \mathrm{C}$ & $\mathbf{L}$ & $\mathrm{N}$ & $0.00 \%$ & $0.21 \%$ & $0.00 \%$ & $0.02 \%$ & $0.07 \%$ \\
\hline $\mathrm{V}$ & BX-109 & TBP & $\mathrm{CW}$ & $1 \mathrm{C}$ & $\mathrm{X}$ & $\mathrm{N}$ & $0.00 \%$ & $1.55 \%$ & $0.00 \%$ & $0.21 \%$ & $0.53 \%$ \\
\hline V & C-101 & TBP & $\mathrm{CW}$ & $\mathbf{P}$ & OWW & $\mathbf{N}$ & $0.00 \%$ & $0.71 \%$ & $0.00 \%$ & $0.05 \%$ & $0.24 \%$ \\
\hline \multicolumn{3}{|c|}{ Group V Subtotal } & & 9 Tanks & & & $0.01 \%$ & $5.45 \%$ & $4.93 \%$ & $0.91 \%$ & $1.96 \%$ \\
\hline VI & B-101 & EB & $\mathrm{CW}$ & $\mathrm{BL}$ & & $\mathrm{N}$ & $0.00 \%$ & $0.91 \%$ & $0.00 \%$ & $0.10 \%$ & $0.31 \%$ \\
\hline VI & B-102 & EB & $\mathrm{CW}$ & $\mathrm{BL}$ & $\mathrm{LX}$ & $\mathrm{N}$ & $0.04 \%$ & $0.14 \%$ & $0.70 \%$ & $0.00 \%$ & $0.09 \%$ \\
\hline VI & B-103 & EB & $\mathrm{CW}$ & $\mathbf{I X}$ & MIX & 0 & $0.00 \%$ & $0.47 \%$ & $0.00 \%$ & $0.00 \%$ & $0.16 \%$ \\
\hline VI & TX-118 & EB & $\mathrm{CW}$ & PNF & & FO & $1.50 \%$ & $0.00 \%$ & $0.00 \%$ & $0.43 \%$ & $0.96 \%$ \\
\hline VI & U-105 & EB & $\mathrm{CW}$ & $\mathbf{R}$ & & G & $1.51 \%$ & $0.26 \%$ & $6.51 \%$ & $2.27 \%$ & $1.16 \%$ \\
\hline VI & U-107 & EB & $\mathrm{CW}$ & MIX & & 0 & $1.56 \%$ & $0.12 \%$ & $5.46 \%$ & $2.35 \%$ & $1.12 \%$ \\
\hline VI & U-108 & EB & $\mathrm{CW}$ & MIX & & G & $1.80 \%$ & $0.23 \%$ & $4.23 \%$ & $2.75 \%$ & $1.30 \%$ \\
\hline VI & U-109 & EB & $\mathrm{CW}$ & $\mathbf{R}$ & & G & $1.71 \%$ & $0.39 \%$ & $3.35 \%$ & $2.60 \%$ & $1.28 \%$ \\
\hline \multicolumn{3}{|c|}{ Group VI Subtotal } & & 8 Tanks & & & $8.13 \%$ & $2.53 \%$ & $20.25 \%$ & $10.50 \%$ & $6.39 \%$ \\
\hline VII & B-201 & 224 & & & & $\mathrm{~N}$ & $0.00 \%$ & $0.23 \%$ & $0.18 \%$ & $0.05 \%$ & $0.08 \%$ \\
\hline VII & B-202 & 224 & & & & $\mathrm{~N}$ & $0.00 \%$ & $0.22 \%$ & $0.00 \%$ & $0.05 \%$ & $0.07 \%$ \\
\hline VII & B-203 & 224 & & & & $\mathrm{~N}$ & $0.00 \%$ & $0.40 \%$ & $0.18 \%$ & $0.08 \%$ & $0.14 \%$ \\
\hline VII & B-204 & 224 & & & & $\mathbf{N}$ & $0.00 \%$ & $0.39 \%$ & $0.18 \%$ & $0.08 \%$ & $0.14 \%$ \\
\hline VII & T-201 & 224 & & & & $\mathrm{~N}$ & $0.00 \%$ & $0.23 \%$ & $0.18 \%$ & $0.05 \%$ & $0.08 \%$ \\
\hline VII & T-202 & 224 & & & & $\mathrm{~N}$ & $0.00 \%$ & $0.17 \%$ & $0.00 \%$ & $0.03 \%$ & $0.06 \%$ \\
\hline VII & T-203 & 224 & & & & $\mathrm{~N}$ & $0.00 \%$ & $0.28 \%$ & $0.00 \%$ & $0.06 \%$ & $0.10 \%$ \\
\hline VII & T-204 & 224 & & & & $\mathbf{N}$ & $0.00 \%$ & $0.31 \%$ & $0.00 \%$ & $0.06 \%$ & $0.11 \%$ \\
\hline \multicolumn{3}{|c|}{ Group VII Subtotal } & & 8 Tanks & & & $0.00 \%$ & $2.22 \%$ & $0.70 \%$ & $0.46 \%$ & $0.78 \%$ \\
\hline
\end{tabular}




\section{Sort on Radioactive Waste Type (SORWT) Model Results}

\begin{tabular}{|c|c|c|c|c|c|c|c|c|c|c|c|}
\hline $\begin{array}{l}\text { SORWT } \\
\text { Group }\end{array}$ & Tank No. & $\begin{array}{c}\text { Primary } \\
\text { Waste } \\
\text { Type } \\
\end{array}$ & $\begin{array}{c}\text { Secondary } \\
\text { Waste Type }\end{array}$ & $\begin{array}{l}\text { Tertiary } \\
\text { Waste } \\
\text { Type } \\
\end{array}$ & $\begin{array}{c}\text { Other } \\
\text { Waste } \\
\text { Type }\end{array}$ & $\begin{array}{c}\text { Watch } \\
\text { List Status }\end{array}$ & $\begin{array}{l}\% \text { of } \\
\text { Total } \\
\text { Saltcake } \\
\text { Volume } \\
\end{array}$ & $\begin{array}{c}\% \text { of } \\
\text { Total } \\
\text { Sludge } \\
\text { Volume }\end{array}$ & $\begin{array}{c}\% \text { of Total } \\
\text { Supernate } \\
\text { Volume }\end{array}$ & $\begin{array}{c}\% \text { of Total } \\
\text { Interstitial } \\
\text { Liquid }\end{array}$ & $\begin{array}{c}\% \text { of } \\
\text { Total } \\
\text { Waste } \\
\text { Volume } \\
\end{array}$ \\
\hline VIII & B-107 & $1 \mathrm{C}$ & EB & $\mathrm{CW}$ & TBP & $\mathrm{N}$ & $0.00 \%$ & $1.32 \%$ & $0.18 \%$ & $0.19 \%$ & $0.46 \%$ \\
\hline VIII & B-108 & $1 \mathrm{C}$ & EB & $\mathrm{CW}$ & IX-TBP & $\mathrm{N}$ & $0.00 \%$ & $0.76 \%$ & $0.00 \%$ & $0.06 \%$ & $0.26 \%$ \\
\hline VIII & B-109 & $1 \mathrm{C}$ & EB & $\mathrm{CW}$ & LX & $\mathrm{N}$ & $0.00 \%$ & $1.02 \%$ & $0.00 \%$ & $0.13 \%$ & $0.35 \% \%^{\circ}$ \\
\hline VIII & BX-110 & 1C & EB-ITS & $\mathrm{CW}$ & LX & $\mathrm{F}$ & $0.04 \%$ & $1.52 \%$ & $0.00 \%$ & $0.24 \%$ & $0.55 \%$ \\
\hline VIII & BX-111 & $1 \mathrm{C}$ & EB-ITS & $\mathrm{CW}$ & IX & F & $0.62 \%$ & $0.55 \%$ & $0.00 \%$ & $0.00 \%$ & $0.58 \%$ \\
\hline VIII & BX-112 & $1 \mathrm{C}$ & EB & $\mathrm{CW}$ & $\mathrm{LX}$ & $\mathrm{N}$ & $0.00 \%$ & $1.32 \%$ & $0.18 \%$ & $0.11 \%$ & $0.46 \%{ }^{\circ}$ \\
\hline \multicolumn{3}{|c|}{ Group VIII Subtotal } & & 6 Tanks & & & $0.66 \%$ & $6.48 \%$ & $0.35 \%$ & $0.74 \%$ & $2.66 \%$ \\
\hline $\mathbf{L}$ & TX-115 & EB & $\mathbf{R}$ & $\mathrm{CW}$ & DW & $\mathrm{N}$ & $2.77 \%$ & $0.00 \%$ & $0.00 \%$ & $0.30 \%$ & $1.77 \%$ \\
\hline IX & U-102 & EB & $\mathbf{R}$ & & & $\mathrm{N}$ & $1.36 \%$ & $0.35 \%$ & $3.17 \%$ & $2.01 \%$ & $1.04 \%$ \\
\hline DX & U-103 & EB & $\mathbf{R}$ & $\mathrm{MIX}$ & & G & $1.83 \%$ & $0.26 \%$ & $2.29 \%$ & $2.81 \%$ & $1.30 \%$ \\
\hline IX & U-106 & EB & $\mathbf{R}$ & $\mathrm{BL}$ & PL & 0 & $0.80 \%$ & $0.21 \%$ & $2.64 \%$ & $1.09 \%$ & $0.63 \%$ \\
\hline $\mathrm{LX}$ & U-111 & EB & $\mathbf{R}$ & $1 \mathrm{C}$ & & o & $1.31 \%$ & $0.21 \%$ & $0.00 \%$ & $1.95 \%$ & $0.91 \%$ \\
\hline \multicolumn{3}{|c|}{ Group LX Subtotal } & & 5 Tanks & & & $8.07 \%$ & $1.02 \%$ & $8.10 \%$ & $8.17 \%$ & $5.64 \%$ \\
\hline $\mathrm{x}$ & C-107 & $1 \mathrm{C}$ & $\mathrm{CW}$ & SRS & & $\mathbf{N}$ & $0.00 \%$ & $2.21 \%$ & $0.00 \%$ & $0.42 \%$ & $0.76 \%$ \\
\hline $\mathrm{x}$ & $T-105$ & $1 \mathrm{C}$ & $\mathrm{CW}$ & $2 \mathrm{C}$ & BL-IX & $\mathrm{N}$ & $0.00 \%$ & $0.79 \%$ & $0.00 \%$ & $0.37 \%$ & $0.27 \%$ \\
\hline $\mathrm{x}$ & $T-106$ & $1 \mathrm{C}$ & $\mathrm{CW}$ & $2 \mathrm{C}$ & MIX & $\mathbf{N}$ & $0.00 \%$ & $0.15 \%$ & $0.35 \%$ & $0.00 \%$ & $0.06 \%$ \\
\hline $\mathrm{x}$ & $\mathrm{T}-107$ & $1 \mathrm{C}$ & $\mathrm{CW}$ & TBP & & F & $0.00 \%$ & $1.38 \%$ & $1.58 \%$ & $0.21 \%$ & $0.50 \%$ \\
\hline $\mathrm{x}$ & U-1 10 & $1 \mathrm{C}$ & $\mathrm{CW}$ & $\mathbf{R}$ & LW & $\mathrm{N}$ & $0.00 \%$ & $1.50 \%$ & $0.00 \%$ & $0.24 \%$ & $0.52 \%$ \\
\hline \multicolumn{3}{|c|}{ Group X Subtotal } & & 5 Tanks & & & $0.00 \%$ & $6.03 \%$ & $1.94 \%$ & $1.23 \%$ & $2.11 \%$ \\
\hline XI & A-101 & DSSF & NCPLX & EVAP & & G & $4.11 \%$ & $0.02 \%$ & $0.00 \%$ & $6.60 \%$ & $2.64 \%$ \\
\hline $\mathbf{X I}$ & A-102 & DSSF & NCPLX & EVAP & & $\mathrm{N}$ & $0.10 \%$ & $0.12 \%$ & $0.70 \%$ & $0.03 \%$ & $0.11 \%$ \\
\hline XI & A-103 & DSSF & NCPLX & EVAP & & $N$ & $0.00 \%$ & $2.94 \%$ & $0.88 \%$ & $0.24 \%$ & $1.03 \%$ \\
\hline $\mathbf{X I}$ & AX-101 & DSSF & NCPLX & EVAP & & G & $3.23 \%$ & $0.02 \%$ & $0.00 \%$ & $5.11 \%$ & $2.07 \%$ \\
\hline \multicolumn{3}{|c|}{ Group XI Subtotal } & & 4 Tanks & & & $7.43 \%$ & $3.11 \%$ & $1.58 \%$ & $11.98 \%$ & $5.85 \%$ \\
\hline $\mathrm{XII}$ & B-106 & $1 \mathrm{C}$ & TBP & HLO & MIX & $\mathrm{N}$ & $0.00 \%$ & $0.93 \%$ & $0.18 \%$ & $0.10 \%$ & $0.32 \%$ \\
\hline XII & BX-107 & $1 \mathrm{C}$ & TBP & $\mathrm{CW}$ & $\mathrm{LX}$ & $\mathbf{N}$ & $0.00 \%$ & $2.77 \%$ & $0.18 \%$ & $0.46 \%$ & $0.96 \%$ \\
\hline XII & C-110 & $1 \mathrm{C}$ & TBP & owW & EB-IX & $\mathrm{N}$ & $0.00 \%$ & $1.50 \%$ & $0.00 \%$ & $0.11 \%$ & $0.52 \%$ \\
\hline XII & $\mathrm{T}-108$ & $1 \mathrm{C}$ & TBP & EB & HLO & $\mathbf{N}$ & $0.00 \%$ & $0.35 \%$ & $0.00 \%$ & $0.00 \%$ & $0.12 \%$ \\
\hline \multicolumn{3}{|c|}{ Group XII Subtotal } & & 4 Tanks & & & $0.00 \%$ & $5.56 \%$ & $0.35 \%$ & $0.67 \%$ & $1.92 \%$ \\
\hline XIII & C-108 & TBP-F & $1 \mathrm{C}$ & $\mathrm{cW}$ & oww & F & $0.00 \%$ & $0.53 \%$ & $0.00 \%$ & $0.00 \%$ & $0.18 \%$ \\
\hline XIII & C-109 & TBP-F & $1 \mathrm{C}$ & $\mathrm{CW}$ & IX & $\mathrm{F}$ & $0.00 \%$ & $0.50 \%$ & $0.70 \%$ & $0.00 \%$ & $0.18 \%$ \\
\hline XIII & C-111 & TBP-F & $1 \mathrm{C}$ & $\mathrm{cW}$ & HS & F & $0.00 \%$ & $0.46 \%$ & $0.00 \%$ & $0.00 \%$ & $0.16 \%$ \\
\hline XIII & C. 112 & TBP-F & $1 \mathrm{C}$ & $\mathrm{CW}$ & $\mathrm{IX}$ & F & $0.00 \%$ & $0.84 \%$ & $0.00 \%$ & $0.51 \%$ & $0.29 \%$ \\
\hline \multicolumn{3}{|c|}{ Group XIII Subtotal } & & 4 Tanks & & & $0.00 \%$ & $2.32 \%$ & $0.70 \%$ & $0.51 \%$ & $0.81 \%$ \\
\hline
\end{tabular}


Sort on Radioactive Waste Type (SORWT) Model Results

\begin{tabular}{|c|c|c|c|c|c|c|c|c|c|c|c|}
\hline $\begin{array}{c}\text { SORWT } \\
\text { Group }\end{array}$ & Tank No. & $\begin{array}{c}\text { Primary } \\
\text { Waste } \\
\text { Type } \\
\end{array}$ & $\begin{array}{c}\text { Secondary } \\
\text { Waste Type } \\
\end{array}$ & $\begin{array}{c}\text { Tertiary } \\
\text { Waste } \\
\text { Type } \\
\end{array}$ & $\begin{array}{c}\text { Other } \\
\text { Waste } \\
\text { Type } \\
\end{array}$ & $\begin{array}{c}\text { Watch } \\
\text { List Status } \\
\end{array}$ & $\begin{array}{c}\% \text { of } \\
\text { Total } \\
\text { Saltcake } \\
\text { Volume } \\
\end{array}$ & $\begin{array}{c}\% \text { of } \\
\text { Total } \\
\text { Sludge } \\
\text { Volume } \\
\end{array}$ & $\begin{array}{c}\% \text { of Total } \\
\text { Supernate } \\
\text { Volume } \\
\end{array}$ & $\begin{array}{c}\% \text { of Total } \\
\text { Interstitial } \\
\text { Liquid } \\
\end{array}$ & $\begin{array}{c}\% \text { of } \\
\text { Total } \\
\text { Waste } \\
\text { Volume } \\
\end{array}$ \\
\hline XIV & C-201 & HS & & & & $\mathbf{N}$ & $0.00 \%$ & $0.02 \%$ & $0.00 \%$ & $0.00 \%$ & $0.01 \%$ \\
\hline XIV & C-202 & HS & & & & $\mathrm{N}$ & $0.00 \%$ & $0.01 \%$ & $0.00 \%$ & $0.00 \%$ & $0.00 \%$ \\
\hline XIV & C-203 & HS & & & & $\mathbf{N}$ & $0.00 \%$ & $0.04 \%$ & $0.00 \%$ & $0.00 \%$ & $0.01 \%$ \\
\hline XIV & C-204 & HS & & & & $\mathbf{N}$ & $0.00 \%$ & $0.02 \%$ & $0.00 \%$ & $0.00 \%$ & $0.01 \%$ \\
\hline \multicolumn{3}{|c|}{ Group XIV Subtotal } & & 4 Tanks & & & $0.00 \%$ & $0.09 \%$ & $0.00 \%$ & $0.00 \%$ & $0.03 \%$ \\
\hline $\mathrm{XV}$ & $T-110$ & $2 \mathrm{C}$ & 224 & & & G & $0.00 \%$ & $3.02 \%$ & $0.53 \%$ & $0.62 \%$ & $1.05 \%$ \\
\hline $\mathrm{XV}$ & T-111 & $2 \mathrm{C}$ & 224 & DW & & 0 & $0.00 \%$ & $3.67 \%$ & $0.35 \%$ & $0.78 \%$ & $1.27 \%$ \\
\hline $\mathrm{XV}$ & T-112 & $2 \mathrm{C}$ & 224 & DW & MIX & $\mathbf{N}$ & $0.00 \%$ & $0.48 \%$ & $1.23 \%$ & $0.00 \%$ & $0.19 \%$ \\
\hline \multicolumn{3}{|c|}{ Group XV Subtotal } & & 3 Tanks & & & $0.00 \%$ & $7.18 \%$ & $2.11 \%$ & $1.41 \%$ & $2.50 \%$ \\
\hline XVI & B-110 & $2 \mathrm{C}$ & $5-6$ & FP & $\mathrm{IX}$ & $\mathrm{N}$ & $0.00 \%$ & $1.97 \%$ & $0.18 \%$ & $0.35 \%$ & $0.68 \%$ \\
\hline XVI & B-111 & $2 \mathrm{C}$ & $5-6$ & FP & IX & $\mathbf{N}$ & $0.00 \%$ & $1.90 \%$ & $0.18 \%$ & $0.34 \%$ & $0.66 \%$ \\
\hline XVI & B-112 & $2 \mathrm{C}$ & $5-6$ & FP & EB-ITS & $\mathrm{N}$ & $0.00 \%$ & $0.24 \%$ & $0.53 \%$ & $0.00 \%$ & $0.09 \%$ \\
\hline \multicolumn{3}{|c|}{ Group XVI Subtotal } & & 3 Tanks & & & $0.00 \%$ & $4.11 \%$ & $0.88 \%$ & $0.69 \%$ & $1.43 \%$ \\
\hline XVII & T-101 & $\mathrm{CW}$ & MIX & TBP-F & EVAP & F & $0.00 \%$ & $0.81 \%$ & $0.18 \%$ & $0.26 \%$ & $0.28 \%$ \\
\hline XVII & T-102 & $\mathrm{CW}$ & MIX & IX & & $\mathbf{N}$ & $0.00 \%$ & $0.15 \%$ & $2.29 \%$ & $0.00 \%$ & $0.09 \%$ \\
\hline XVII & T-103 & $\mathrm{CW}$ & MIX & & & $\mathrm{N}$ & $0.00 \%$ & $0.19 \%$ & $0.70 \%$ & $0.00 \%$ & $0.07 \%$ \\
\hline \multicolumn{3}{|c|}{ Group XVII Subtotal } & & 3 Tanks & & & $0.00 \%$ & $1.15 \%$ & $3.17 \%$ & $0.26 \%$ & $0.45 \%$ \\
\hline XVIII & U-201 & $\mathrm{CW}$ & & & & $\mathbf{N}$ & $0.00 \%$ & $0.03 \%$ & $0.18 \%$ & $0.00 \%$ & $0.01 \%$ \\
\hline XVIII & U-202 & $\mathrm{CW}$ & & & & $\mathrm{N}$ & $0.00 \%$ & $0.03 \%$ & $0.18 \%$ & $0.00 \%$ & $0.01 \%$ \\
\hline XVIII & U-203 & $\mathrm{CW}$ & & & & $\mathrm{N}$ & $0.00 \%$ & $0.02 \%$ & $0.18 \%$ & $0.00 \%$ & $0.01 \%$ \\
\hline \multicolumn{3}{|c|}{ Group XVIII Subtotal } & & 3 Tanks & & & $0.00 \%$ & $0.08 \%$ & $0.53 \%$ & $0.00 \%$ & $0.04 \%$ \\
\hline $\mathrm{XIX}$ & BY-102 & TBP & EB-ITS & $\mathrm{CW}$ & $1 \mathrm{C}$ & $\mathrm{N}$ & $1.48 \%$ & $0.00 \%$ & $0.00 \%$ & $0.66 \%$ & $0.94 \%$ \\
\hline $\mathrm{XIX}$ & BY-109 & TBP & EB-ITS & $C W$ & MW & $\mathrm{N}$ & $1.47 \%$ & $0.67 \%$ & $0.00 \%$ & $1.25 \%$ & $1.17 \%$ \\
\hline \multicolumn{3}{|c|}{ Group XIX Subtotal } & & 2 Tanks & & & $2.95 \%$ & $0.67 \%$ & $0.00 \%$ & $1.90 \%$ & $2.12 \%$ \\
\hline $\mathrm{XX}$ & C-103 & SRS & SR-WASH & $\mathbf{P}$ & TBP-CW & 0 & $0.00 \%$ & $0.50 \%$ & $23.42 \%$ & $0.00 \%$ & $0.54 \%$ \\
\hline$X X$ & C-106 & SRS & SR-WASH & $\mathbf{P}$ & TBP & $\mathbf{H}$ & $0.00 \%$ & $1.58 \%$ & $5.63 \%$ & $0.26 \%$ & $0.63 \%$ \\
\hline \multicolumn{3}{|c|}{ Group XX Subtotal } & & 2 Tanks & & . & $0.00 \%$ & $2.08 \%$ & $29.05 \%$ & $0.26 \%$ & $1.17 \%$ \\
\hline XXI & T-109 & TBP & EB & MIX & & $\mathbf{N}$ & $0.00 \%$ & $0.47 \%$ & $0.00 \%$ & $0.00 \%$ & $0.16 \%$ \\
\hline XXI & TX-103 & TBP & EB & & & $\mathrm{N}$ & $0.00 \%$ & $1.26 \%$ & $0.00 \%$ & $0.24 \%$ & $0.43 \%$ \\
\hline \multicolumn{3}{|c|}{ Group XXI Subtotal } & & 2 Tanks & & & $0.00 \%$ & $1.73 \%$ & $0.00 \%$ & $0.24 \%$ & $0.60 \%$ \\
\hline $\mathrm{XXII}$ & TY-103 & TBP & IC-F & $\mathrm{CW}$ & R-MIX & $\mathrm{F}$ & $0.00 \%$ & $1.30 \%$ & $0.00 \%$ & $0.08 \%$ & $0.45 \%$ \\
\hline XXII & TY-104 & TBP & $1 \mathrm{C}-\mathrm{F}$ & DW & MIX-R & $\mathrm{F}$ & $0.00 \%$ & $0.35 \%$ & $0.53 \%$ & $0.19 \%$ & $0.13 \%$ \\
\hline \multicolumn{3}{|c|}{ XXII Subtotal } & & 2 Tanks & & & $0.00 \%$ & $1.65 \%$ & $0.53 \%$ & $0.27 \%$ & $0.58 \%$ \\
\hline
\end{tabular}




\section{Sort on Radioactive Waste Type (SORWT) Model Results}

\begin{tabular}{|c|c|c|c|c|c|c|c|c|c|c|c|}
\hline $\begin{array}{l}\text { SORWT } \\
\text { Group }\end{array}$ & Tank No. & $\begin{array}{l}\text { Primary } \\
\text { Waste } \\
\text { Type }\end{array}$ & $\begin{array}{c}\text { Secondary } \\
\text { Waste Type }\end{array}$ & $\begin{array}{l}\text { Tertiary } \\
\text { Waste } \\
\text { Type }\end{array}$ & $\begin{array}{l}\text { Other } \\
\text { Waste } \\
\text { Type }\end{array}$ & $\begin{array}{c}\text { Watch } \\
\text { List Status }\end{array}$ & $\begin{array}{l}\% \text { of } \\
\text { Total } \\
\text { Saltcake } \\
\text { Volume }\end{array}$ & $\begin{array}{c}\% \text { of } \\
\text { Total } \\
\text { Sludge } \\
\text { Volume }\end{array}$ & $\begin{array}{c}\% \text { of Total } \\
\text { Supernate } \\
\text { Volume }\end{array}$ & $\begin{array}{l}\% \text { of Total } \\
\text { Interstitial } \\
\text { Liquid }\end{array}$ & $\begin{array}{c}\% \text { of } \\
\text { Total } \\
\text { Waste } \\
\text { Volume }\end{array}$ \\
\hline XXIII & AX-102 & CCPLX & DSSF & EVAP & & $\mathrm{N}$ & $0.13 \%$ & $0.06 \%$ & $0.53 \%$ & $0.22 \%$ & $0.11 \%$ \\
\hline XXIII & AX-103 & CCPLX & DSSF & EVAP & & G & $0.48 \%$ & $0.02 \%$ & $0.00 \%$ & $0.58 \%$ & $0.31 \%$ \\
\hline \multicolumn{3}{|c|}{ Group XXIII Subtotal } & & 2 Tanks & & & $0.60 \%$ & $0.07 \%$ & $0.53 \%$ & $0.80 \%$ & $0.42 \%$ \\
\hline XXIV & SX-113 & $\mathbf{R}$ & DIA & & & $\mathrm{N}$ & $0.00 \%$ & $0.21 \%$ & $0.00 \%$ & $0.00 \%$ & $0.07 \%$ \\
\hline XXIV & U-104 & $\mathbf{R}$ & DIA & & & $\mathrm{N}$ & $0.00 \%$ & $0.98 \%$ & $0.00 \%$ & $0.11 \%$ & $0.34 \%$ \\
\hline \multicolumn{3}{|c|}{ Group XXIV Subtotal } & & 2 Tanks & & & $0.00 \%$ & $1.19 \%$ & $0.00 \%$ & $0.11 \%$ & $0.41 \%$ \\
\hline XXVA & A-104 & SLUICE & $\mathbf{P}$ & $\mathrm{H} 20$ & B & $\mathrm{H}$ & $0.00 \%$ & $0.23 \%$ & $0.00 \%$ & $0.00 \%$ & $0.08 \%$ \\
\hline XXVB & A-105 & $\mathbf{P}$ & IX & & & $\mathrm{H}$ & $0.00 \%$ & $0.15 \%$ & $0.00 \%$ & $0.06 \%$ & $0.05 \%$ \\
\hline $\mathrm{XXVC}$ & A-106 & CCPLX & NCPLX & EVAP & B & $\mathbf{N}$ & $0.00 \%$ & $1.01 \%$ & $0.00 \%$ & $0.11 \%$ & $0.35 \%$ \\
\hline XXVD & AX-104 & EVAP & NCPLX & $\mathbf{P}$ & & $\mathbf{N}$ & $0.00 \%$ & $0.06 \%$ & $0.00 \%$ & $0.00 \%$ & $0.02 \%$ \\
\hline XXVE & B-104 & $2 \mathrm{C}$ & EB & TBP & $1 \mathrm{C}$ & $\mathbf{N}$ & $0.30 \%$ & $2.42 \%$ & $0.18 \%$ & $0.74 \%$ & $1.03 \%$ \\
\hline $\mathrm{XXVF}$ & C-102 & $\mathrm{CW}$ & TBP & OWW & & $\mathbf{N}$ & $0.00 \%$ & $3.40 \%$ & $0.00 \%$ & $0.59 \%$ & $1.17 \%$ \\
\hline XXVG & C-104 & $\mathrm{CW}$ & OWW & SR-WAS & SRS & $\mathrm{MXN}$ & $0.00 \%$ & $2.37 \%$ & $0.00 \%$ & $0.18 \%$ & $0.82 \%$ \\
\hline $\mathrm{XXVH}$ & C-105 & TBP & SR-WASH & $\mathrm{CW}$ & $\mathbf{P}$ & $\mathrm{H}$ & $0.00 \%$ & $1.21 \%$ & $0.00 \%$ & $0.18 \%$ & $0.42 \%$ \\
\hline XXVI & T-104 & $1 \mathrm{C}$ & & & & $\mathbf{N}$ & $0.00 \%$ & $3.56 \%$ & $0.53 \%$ & $0.75 \%$ & $1.23 \%$ \\
\hline XXVJ & TX-101 & $\mathbf{R}$ & MIX & MIX & & $\mathbf{N}$ & $0.00 \%$ & $0.68 \%$ & $0.53 \%$ & $0.03 \%$ & $0.24 \%$ \\
\hline $\mathrm{XXVK}$ & TX-108 & EB & DW & & & $\mathbf{N}$ & $0.58 \%$ & $0.00 \%$ & $0.00 \%$ & $0.00 \%$ & $0.37 \%$ \\
\hline XXVL & TY-101 & IC-F & EB & TBP & $\mathbf{R}$ & F & $0.00 \%$ & $0.95 \%$ & $0.00 \%$ & $0.00 \%$ & $0.33 \%$ \\
\hline $\mathrm{XXVM}$ & TY-105 & TBP & & & & $\mathbf{N}$ & $0.00 \%$ & $1.86 \%$ & $0.00 \%$ & $0.00 \%$ & $0.64 \%$ \\
\hline XXVN & TY-106 & TBP & DIA & & & $\mathrm{N}$ & $0.00 \%$ & $0.14 \%$ & $0.00 \%$ & $0.00 \%$ & $0.05 \%$ \\
\hline XXVO & U-204 & $\mathbf{R}$ & $2 \mathrm{C}$ & CW & & $\mathbf{N}$ & $0.00 \%$ & $0.02 \%$ & $0.18 \%$ & $0.00 \%$ & $0.01 \%$ \\
\hline XXVP & U-112 & UK & & & & $\mathrm{N}$ & $0.00 \%$ & $0.36 \%$ & $0.70 \%$ & $0.00 \%$ & $0.14 \%$ \\
\hline \multicolumn{3}{|c|}{ Ungrouped Subtotal } & & 16 Tanks & & & $0.88 \%$ & $18.40 \%$ & $2.11 \%$ & $2.64 \%$ & $6.93 \%$ \\
\hline \multicolumn{3}{|c|}{ Total Inventory } & & & & & $100 \%$ & $100 \%$ & $100 \%$ & $100 \%$ & $100 \%$ \\
\hline
\end{tabular}


Appendix B

\section{Waste Types in Hanford Site Single-Shell Tanks}


. 


\section{Waste Types in Hanford Site Single-Shell Tanks}

This appendix summarizes available information that describes wastes in the Hanford Site single-shell tanks (SST). The complexity of the waste-generating processes, the waste transfers from generating facilities to SSTs, and the transactions between SSTs severely compromises the completeness and accuracy of the information contained in this appendix. These data, however, provide information to support tank categorization before actual characterization of SST waste.

The characterizations of waste types contained in this report were taken from a wide variety of sources. Compositions of the primary waste streams from two main extraction processes, bismuth phosphate $\left(\mathrm{BiPO}_{4}\right)$ and reduction oxidation (REDOX), as well as waste from the uranium extraction process at $U$ Plant, were obtained from process flowsheets. For the plutonium-uranium extraction (PUREX) and B Plant waste fractionization processes, published reports of waste compositions were relied upon because of the complex process chemistry and several changes in flowsheets. The low-level waste and flush waste compositions are difficult to specify but can be assumed to be very dilute. In general, most low-level waste was sent to the cribs; only a small amount was sent to the SSTs. For the various campaigns to extract cesium and strontium (and in some cases other fission products), waste compositions were taken from process flowsheets when available. Some caution must be taken in evaluating the results because of several sources of error, including variability of the feed material, changes in process flowsheets, and the presence or absence of diluting streams such as wash wastes. Laboratory wastes from three laboratories operating at the Hanford Site also went into the SSTs; the composition of these wastes is unknown.

Not all of the named waste types have a unique point of origin. Some wastes result from evaporation of wastes already contained in SSTs, and other wastes are merely new names assigned to old wastes to reflect their suitability for further processing, including evaporation. During the early history of the Hanford Site, there was little interest in determining the composition of chemical waste streams, and little or no attempt was made to segregate wastes from different processes. The overriding concern during this period was to minimize waste volume to conserve space in the SSTs. To this end, from the early 1950s, waste in the SSTs was extensively subjected to evaporation. In the evaporators, supernatant liquids from the waste tanks were heated until a slurry was formed; this slurry was returned to the tanks, where a solid salt cake precipitated. Residual supernatant liquors were pumped to other tanks and re-evaporated. In another method, heaters were placed directly in the tanks and the wastes were evaporated without any transfers.

Because of the detection of leaks in several of the SSTs in the 1970s, it became necessary to reduce SST liquid wastes to a solid form or transfer them to the newly constructed double-shell tanks (DST). At this time, SST supernatant liquids were given designations according to the presence or absence of organic complexants and the suitability of the waste for further evaporation. For example, complexant concentrate (CC) waste was considered unsuitable for further evaporation at the SSTs because it was thought that the organic complexants might form a gel, making the waste difficult to pump. In contrast, evaporator feed (EF) was relatively dilute supernatant liquid that was suitable for evaporation. Terminal and residual liquors--waste types TL, HDRL, and RESD--should not be further evaporated at the SSTs because they would precipitate 1) fine aluminate solids that would settle and drain poorly or 2) deliquescent $\mathrm{NaOH}$ solids that would take up moisture from the air and redissolve. These waste types, designated double-shell slurry feed (DSSF), were pumped to the DSTs and then evaporated into a slurry. Because of the DSTs' secure construction, they were deemed suitable to accept liquids, suspended solids, and poorly draining slurries for indefinite storage. 


\section{WASTE DESCRIPTIONS}

The following are brief descriptions and chemical compositions, where available, of 49 waste types discharged to the SSTs.

1. B. High-level waste from waste fractionization process at B Plant starting in 1967.

\begin{tabular}{l} 
Approximate Composition \\
\begin{tabular}{|l|l|}
\hline Element/isotope & mol/L \\
\hline $\mathrm{Al}$ & 0.079 \\
\hline $\mathrm{Ba}$ & 0.000032 \\
\hline $\mathrm{Ca}$ & 0.0001 \\
\hline $\mathrm{Cr}$ & 0.002 \\
\hline $\mathrm{C}_{6} \mathrm{H}_{5} \mathrm{O}_{7}$ (cirrate) & 0.12 \\
\hline $\mathrm{Fe}$ & 0.029 \\
\hline $\mathrm{Mn}$ & 0.00029 \\
\hline $\mathrm{Na}$ & 1.29 \\
\hline $\mathrm{Ni}$ & 0.002 \\
\hline${ }^{106} \mathrm{Ru}$ & 0.000003 \\
\hline $\mathrm{Pu}$ & 0.000001 \\
\hline $\mathrm{NO}{ }_{3}$ & 1.27 \\
\hline $\mathrm{Tc}$ & 0.000048 \\
\hline $\mathrm{U}$ & 0.0029 \\
\hline $\mathrm{Zr}$ & 0.000048 \\
\hline
\end{tabular} \\
\hline
\end{tabular}

2. B Plant Flush (BFSH). Flush water from the B Plant during the time of the $\mathrm{BiPO}_{4}$ process in the 1950s.

3. BIX. This is a misprint for RIX. 
4. BL. Low-level waste from the waste fractionization plant beginning in 1968 .

Typical Composition

\begin{tabular}{|l|l|}
\hline \multicolumn{1}{|c|}{ Element/isotope } & $\mathrm{mol} / \mathrm{L}$ \\
\hline $\mathrm{Al}$ & 0.55 \\
\hline $\mathrm{C}_{6} \mathrm{H}_{5} \mathrm{O}_{7}$ (citrate) & 0.92 \\
\hline $\mathrm{Ca}$ & 0.000005 \\
\hline $\mathrm{CO}_{3}$ & 2.61 \\
\hline $\mathrm{Mn}$ & 0.0029 \\
\hline $\mathrm{Na}$ & 5.55 \\
\hline $\mathrm{Ni}$ & 0.0092 \\
\hline $\mathrm{NO}{ }_{3}$ & 5.28 \\
\hline $\mathrm{Pb}$ & 0.014 \\
\hline $\mathrm{Pu}$ & 0.00087 \\
\hline $\mathrm{SiO}$ & 0.0029 \\
\hline $\mathrm{U}$ & 0.37 \\
\hline
\end{tabular}

5. BLEB. Evaporator bottoms where B Plant low-level waste was the feed material.

6. BNW. Laboratory waste from Pacific Northwest Laboratory.

7. CARB. Organic wash waste from the PUREX Plant before 1963, using sodium carbonate solution.

\begin{tabular}{|l|c|}
\multicolumn{2}{|c|}{ Approximate Composition } \\
\hline $\mathrm{CO}_{3}$ & $\mathrm{~mol} / \mathrm{L}$ \\
\hline $\mathrm{Na}$ & 0.21 \\
\hline $\mathrm{NO}_{3}$ & 0.43 \\
\hline $\mathrm{UO}_{2}$ & 0.07 \\
\hline
\end{tabular}


8. Complexant Concentrate (CCPL or CC). Contains a high concentration of organic complexants such as HEDTA, EDTA, and citric acid as a result of B Plant processing and subsequent evaporation. Any further concentration of this waste would cause the complexants to form a gel that would not be pumpable nor considered suitable for storage in SSTs. The given composition is an average of sampled tanks.

\begin{tabular}{|c|c|}
\hline \multicolumn{2}{|c|}{ Average Composition } \\
\hline Element/isotope & $\mathrm{mol} / \mathrm{L}$ \\
\hline $\mathrm{Al}$ & 0.38 \\
\hline $\mathrm{Ba}$ & 0.0001 \\
\hline $\mathrm{Ca}$ & 0.013 \\
\hline Cd & 0.00062 \\
\hline $\mathrm{Cl}$ & 0.05 \\
\hline $\mathrm{CO}_{3}$ & 0.96 \\
\hline $\mathrm{C}_{\mathbf{r}}$ & 0.0046 \\
\hline $\mathrm{Cu}$ & 0.00032 \\
\hline F & 0.12 \\
\hline $\mathbf{F e}$ & 0.023 \\
\hline $\mathbf{K}$ & 0.032 \\
\hline $\mathrm{La}$ & 0.00065 \\
\hline $\mathbf{M g}$ & 0.0012 \\
\hline Mn & 0.0016 \\
\hline Mo & 0.003 \\
\hline $\mathrm{Na}$ & 7.3 \\
\hline $\mathrm{Ni}$ & 0.006 \\
\hline $\mathrm{NO}_{2}$ & 0.78 \\
\hline $\mathrm{NO}_{3}$ & 2.7 \\
\hline $\mathrm{OH}$ & 0.36 \\
\hline $\mathrm{Pb}$ & 0.0012 \\
\hline $\mathrm{PO}_{4}$ & 0.026 \\
\hline Si . & 0.0031 \\
\hline $\mathrm{SO}_{4}$ & 0.09 \\
\hline $\mathrm{Zn}$ & 0.0006 \\
\hline $\mathrm{Zr}$ & 0.0013 \\
\hline
\end{tabular}

B.4 
9. Cesium Feed (CF). Small quantities of this waste were put into Tank C-105 in 1976. It was a PUREX or PUREX sludge supernatant. For a typical composition, see waste type PSS.

10. Complexed Waste (CPLX). Dilute waste material containing relatively high concentrations of organic chelating agents such as EDTA and HEDTA from the B Plant waste fractionization process. This waste type is defined as containing at least $10 \mathrm{~g} / \mathrm{L}$ organic material, or $100 \mathrm{mCi} / \mathrm{g}$ radionuclides. This is a later designation (post-1976) that does not reflect the bulk composition or point of origin of the waste, but merely re-labels all the waste in a tank according to the presence or absence of B Plant complexants.

\begin{tabular}{|c|c|}
\hline Element/isotope & $\mathrm{mol} / \mathrm{L}$ \\
\hline $\mathrm{A} 1$ & 0.1 \\
\hline $\mathrm{CO}_{3}$ & 0.5 \\
\hline F & 0.007 \\
\hline $\mathrm{Na}$ & 2.7 \\
\hline $\mathrm{NO}_{2}$ & 0.27 \\
\hline $\mathrm{NO}_{3}$ & 0.72 \\
\hline $\mathrm{OH}$ & 0.25 \\
\hline $\mathrm{PO}_{4}$ & 0.014 \\
\hline $\mathrm{SO}_{4}$ & 0.176 \\
\hline
\end{tabular}


11. CW. Waste produced at the PUREX Plant from dissolution of zircaloy (after 1964) or aluminum fuel cladding. The zircaloy cladding was dissolved in an ammonium/fluoride, ammonium nitrate solution. The aluminum cladding was dissolved in a sodium nitrate/sodium hydroxide solution.

Approximate Composition -

Zircaloy Cladding

\begin{tabular}{|l|l|}
\hline \multicolumn{1}{|c|}{ Element/isotope } & $\mathrm{mol} / \mathrm{L}$ \\
\hline $\mathrm{F}$ & 1.01 \\
\hline $\mathrm{Na}$ & 1.4 \\
\hline $\mathrm{NO}_{3}$ & 0.02 \\
\hline $\mathrm{OH}$ & 0.37 \\
\hline $\mathrm{Pu}$ & 0.0006 \\
\hline $\mathrm{U}$ & 0.0008 \\
\hline $\mathrm{ZrO}_{2}$ & 0.15 \\
\hline
\end{tabular}

Alumimum Cladding

\begin{tabular}{|l|c|}
\hline Element/isotope & $\mathrm{mol} / \mathrm{L}$ \\
\hline $\mathrm{Al}$ & 1 \\
\hline $\mathrm{Na}$ & 3.7 \\
\hline $\mathrm{NO}_{2}$ & 0.9 \\
\hline $\mathrm{NO}_{3}$ & 0.6 \\
\hline $\mathrm{OH}$ & 1 \\
\hline $\mathrm{Si}$ & 0.02 \\
\hline
\end{tabular}

12. CWP. In 1963, some coating waste from the PUREX Plant was called CWP. See waste type CW. 
13. CWR. REDOX process waste resulting from the dissolution of fuel element cladding. Both aluminum- and zircaloy-clad fuels were processed.

$\begin{gathered}\text { Approximate Composition of } \\
\text { Aluminum Cladding Waste }\end{gathered}$
\begin{tabular}{|l|l|}
\hline Element/isotope & $\mathrm{mol} / \mathrm{L}$ \\
\hline $\mathrm{Al}$ & 2.32 \\
\hline $\mathrm{Na}$ & 5.9 \\
\hline $\mathrm{NO}_{2}$ & 1.47 \\
\hline $\mathrm{NO}_{3}$ & 1.07 \\
\hline $\mathrm{OH}$ & 1 \\
\hline $\mathrm{Pu}$ & 0.000004 \\
\hline $\mathrm{U}$ & 0.0058 \\
\hline
\end{tabular}

$$
\begin{aligned}
& \text { Approximate Composition of } \\
& \text { Zircaloy Cladding Waste }
\end{aligned}
$$

\begin{tabular}{|l|l|}
\hline Element/isotope & $\mathrm{mol} / \mathrm{L}$ \\
\hline $\mathrm{Al}$ & 0.21 \\
\hline $\mathrm{F}$ & 2.25 \\
\hline $\mathrm{Na}$ & 3.73 \\
\hline $\mathrm{NO}_{2}$ & 0.17 \\
\hline $\mathrm{NO}_{3}$ & 0.97 \\
\hline $\mathrm{OH}$ & 1.39 \\
\hline $\mathrm{P}$ & 0.000008 \\
\hline $\mathrm{U}$ & 0.018 \\
\hline $\mathrm{Zr}$ & 0.31 \\
\hline
\end{tabular}

14. Diatomaceous earth (DE). $\mathrm{SiO}_{2}$. 
15. DSSF. Noncomplexed waste that has been concentrated in evaporators until the solution is nearly saturated with sodium aluminate. Further evaporation will yield a slurry that is not suitable for storage in SSTs. This is a general term for noncomplexed HDRL (Hanford defense residual liquor), including partially neutralized waste.

Typical Composition

\begin{tabular}{|l|c|}
\hline Element/isotope & $\mathrm{mol} / \mathrm{L}$ \\
\hline $\mathrm{Al}$ & 1.74 \\
\hline $\mathrm{CO}_{3}$ & 0.21 \\
\hline $\mathrm{F}$ & 0.06 \\
\hline $\mathrm{Na}$ & 12.53 \\
\hline $\mathrm{NO}_{2}$ & 2.62 \\
\hline $\mathrm{NO}_{3}$ & 2.72 \\
\hline $\mathrm{OH}$ & 3.43 \\
\hline $\mathrm{PO}_{4}$ & 0.07 \\
\hline
\end{tabular}

16. Decontamination Waste (DW). Wash solution from equipment decontamination efforts at the $\mathrm{T}$ Plant. This waste was mainly a dilute $\mathrm{NaNO}_{2}$ solution, averaging 0.24 $\underline{\mathrm{M}} \mathrm{NaNO}_{2}$.

17. Evaporator Bottoms (EB). Slurry product from the evaporators. This slurry precipitated a solid salt cake that was stored in SSTs.

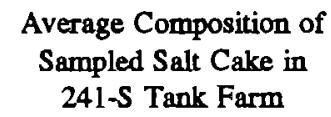

\begin{tabular}{|l|c|}
\hline \multicolumn{1}{|c|}{ Element/isotope } & Weight \% \\
\hline $\mathrm{H}_{2} \mathrm{O}$ & 12.8 \\
\hline $\mathrm{NaAlO}_{2}$ & 1.9 \\
\hline $\mathrm{Na}_{2} \mathrm{CO}_{3}$ & 6.4 \\
\hline $\mathrm{NaNO}_{2}$ & 1.8 \\
\hline $\mathrm{NaNO}_{3}$ & 73.8 \\
\hline $\mathrm{Na}_{3}\left(\mathrm{PO}_{4}\right)_{2}$ & 1.5 \\
\hline
\end{tabular}


18. Evaporator Feed (EF). This term designates various kinds of supernatant liquids whose composition depends on source location and whether they underwent prior concentration. In general, EF may be either dilute feed that has not yet been evaporated or concentrated feed that has been partially evaporated but requires additional evaporation to meet requirements for residual liquor.

Typical Composition of Dihute Feed

\begin{tabular}{|l|l|}
\hline Element/isotope & $\mathrm{mol} / \mathrm{L}$ \\
\hline $\mathrm{Al}$ & 0.4 \\
\hline $\mathrm{CO}_{3}$ & 0.2 \\
\hline $\mathrm{Na}$ & 4.5 \\
\hline $\mathrm{NO}_{2}$ & 0.6 \\
\hline $\mathrm{NO}_{3}$ & 2.3 \\
\hline $\mathrm{OH}$ & 0.7 \\
\hline $\mathrm{PO}_{4}$ & 0.03 \\
\hline
\end{tabular}

Typical Composition of Concentrated Feed

\begin{tabular}{|l|l|}
\hline Element/isotope & $\mathrm{mol} / \mathrm{L}$ \\
\hline $\mathrm{Al}$ & 0.9 \\
\hline $\mathrm{CO}_{3}$ & 0.23 \\
\hline $\mathrm{Na}$ & 8.26 \\
\hline $\mathrm{NO}_{2}$ & 1.6 \\
\hline $\mathrm{NO}_{3}$ & 3.6 \\
\hline $\mathrm{OH}$ & 1.7 \\
\hline $\mathrm{PO}_{4}$ & 0.05 \\
\hline
\end{tabular}

19. EVAP. This is a post-1976 designation for evaporator feed. For typical composition, see No. 18 Evaporator Feed (EF). With the exception of terminal liquors, which could not be further evaporated, and aging waste, which contained short-lived, highheat fission products, any tank supernatant liquor could be designated evaporator feed.

20. Fission Products (FP) Waste. Waste produced at B Plant and Hot Semiworks during the 1960s in campaigns to isolate various fission products such as cerium and promethium. 
21. Hanford Defense Residual Liquor. This is a late 1970 s designation for terminal liquors remaining after waste evaporation, these including complexed and noncomplexed waste, partially neutralized wastes, and DSSF. Further evaporation of these wastes would cause precipitation of solids unsuitable for storage in SSTs. Composition is the same as No. 44 Terminal Liquor, TL.

22. Hanford Laboratory Operations (HLO). Laboratory waste from 300 Area.

23. $\underline{\text { HS}}$. Waste from Hot Semiworks Plant, which ran several strontium extraction campaigns from 1955 until 1961. There were 50,000 gallons of dilute wastes discharged to tank farms. For approximate chemical composition see SSW, Strontium Semiworks Waste.

24. Water $\left(\mathrm{H}_{2} \mathrm{O}\right)$. Filtered Hanford Site water (200 East Area) contains the following impurities in parts per million:

Filtered Hanford Site 200 East Water Impurities

\begin{tabular}{|l|c|}
\hline Element/isotope & $\mathrm{ppm}$ \\
\hline $\mathrm{Ca}$ & $20-40$ \\
\hline $\mathrm{Cl}$ & $1-5$ \\
\hline $\mathrm{CO}_{2}$ & $0-2$ \\
\hline $\mathrm{Mg}$ & $4-5.5$ \\
\hline $\mathrm{SO}_{4}$ & $14-30$ \\
\hline $\mathrm{SiO}_{4}$ & $3-7.5$ \\
\hline
\end{tabular}


25. IWW. Concentrated, neutralized high-level waste from the PUREX process. This waste type only entered the tank farms in one occurrence and is probably equivalent to waste type P. It should actually be written as $1 \mathrm{WW}$ and is bottom waste from the No. 1 acid concentrator.

Approximate Composition

\begin{tabular}{|l|l|}
\hline Element/isotope & \multicolumn{1}{c|}{$\mathrm{mol} / \mathrm{L}$} \\
\hline $\mathrm{Fe}$ & 0.05 \\
\hline $\mathrm{Na}$ & 5.37 \\
\hline $\mathrm{NO}_{3}$ & 5.82 \\
\hline $\mathrm{OH}$ & 5.37 \\
\hline $\mathrm{Pu}$ & 0.000007 \\
\hline $\mathrm{SO}_{4}$ & 0.1 \\
\hline $\mathrm{U}$ & 0.0126 \\
\hline
\end{tabular}

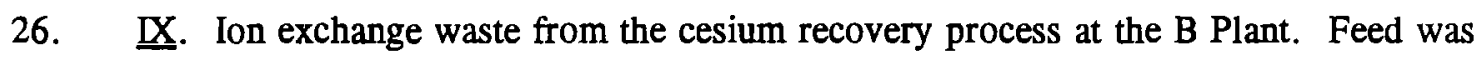
PUREX supernatant. This includes column waste, column wash waste, and cesium purification waste.

Approximate Composition

\begin{tabular}{|l|l|}
\hline Element/isotope & $\mathrm{mol} / \mathrm{L}$ \\
\hline $\mathrm{CO}_{3}$ & 0.65 \\
\hline $\mathrm{Na}$ & 3.9 \\
\hline $\mathrm{NO}_{2}$ & 1.9 \\
\hline $\mathrm{NO}_{3}$ & 0.49 \\
\hline $\mathrm{SO}_{4}$ & 0.085 \\
\hline
\end{tabular}

27. LW. Laboratory waste from 222-S Building. 
28. MW. Metal waste from the $\mathrm{BiPO}_{4}$ process. It was produced at the $\mathrm{B}$ and $\mathrm{T}$ Plants from the dissolution of uranium fuel elements.

Approximate Composition
\begin{tabular}{|l|c|}
\hline Element/isotope & $\mathrm{mo} / \mathrm{L}$ \\
\hline $\mathrm{CO}_{3}$ & 1.14 \\
\hline $\mathrm{Na}$ & 3.53 \\
\hline $\mathrm{NO}_{3}$ & 0.59 \\
\hline $\mathrm{OH}$ & 1.16 \\
\hline $\mathrm{PO}_{4}$ & 0.23 \\
\hline $\mathrm{SO}_{4}$ & 0.24 \\
\hline $\mathrm{U}$ & 0.25 \\
\hline
\end{tabular}

29. ‥ Phosphate decontamination waste from N Reactor. After 1982 ion-exchange regeneration waste containing sodium sulfate was produced. The following composition is for post-1980 N Reactor waste; N Reactor waste produced during the time when the SSTs were active is assumed to be similar.

Approximate Composition of Concentrated Phosphate Waste

\begin{tabular}{|l|c|}
\hline \multicolumn{1}{|c|}{ Element/isotope } & $\mathrm{mol} / \mathrm{L}$ \\
\hline $\mathrm{Na}$ & 1.11 \\
\hline $\mathrm{NO}_{2}$ & 0.014 \\
\hline $\mathrm{OH}$ & 0.01 \\
\hline $\mathrm{PO}_{4}$ & 0.36 \\
\hline
\end{tabular}


30. Noncomplexed Waste (NCPL). A general term for supernatant liquids and saltwell liquors not identified as containing organic complexants. This term came into use after 1976 and does not reflect origin or composition of the waste, only its suitability for further treatment.

Estimated Composition

\begin{tabular}{|l|l|}
\hline Element/isotope & $\mathrm{mol} / \mathrm{L}$ \\
\hline $\mathrm{Al}$ & 1.5 \\
\hline $\mathrm{CO}_{3}$ & 0.2 \\
\hline $\mathrm{Na}$ & 10.6 \\
\hline $\mathrm{NO}_{2}$ & 2.2 \\
\hline $\mathrm{NO}_{3}$ & 3.3 \\
\hline $\mathrm{PO}_{4}$ & 0.08 \\
\hline
\end{tabular}

31. OWW. Organic solvent wash waste from the PUREX Plant, containing carbonate, permanganate, and nitrate.

Approximate Composition

\begin{tabular}{|l|c|}
\hline Element/isotope & $\mathrm{mol} / \mathrm{L}$ \\
\hline $\mathrm{CO}_{3}$ & 0.21 \\
\hline $\mathrm{K}$ & 0.01 \\
\hline $\mathrm{MnO}_{4}$ & 0.01 \\
\hline $\mathrm{MnO}_{2}$ & 0.01 \\
\hline $\mathrm{Na}$ & 0.27 \\
\hline $\mathrm{NO}_{3}$ & 0.06 \\
\hline $\mathrm{U}$ & 0.008 \\
\hline
\end{tabular}


32. $\quad$. High-activity neutralized acid waste generated by the PUREX process.

Approximate Composition

\begin{tabular}{|l|l|}
\hline Element/isotope & $\mathrm{mol} / \mathrm{L}$ \\
\hline $\mathrm{Al}$ & 0.15 \\
\hline $\mathrm{Fe}$ & 0.4 \\
\hline $\mathrm{Na}$ & 1.4 \\
\hline $\mathrm{NO}_{3}$ & 1.3 \\
\hline $\mathrm{PO}_{4}$ & 0.02 \\
\hline $\mathrm{SO}_{4}$ & 0.9 \\
\hline
\end{tabular}

33. PL. Low-level waste from the PUREX Plant.

Approximate Composition

\begin{tabular}{|l|c|}
\hline Element/isotope & $\mathrm{mol} / \mathrm{L}$ \\
\hline $\mathrm{Na}$ & 0.0013 \\
\hline $\mathrm{NO}_{3}$ & 0.0026 \\
\hline $\mathrm{Np}$ & $5.0 \mathrm{E}-7$ \\
\hline $\mathrm{Pu}$ & $3.2 \mathrm{E}-6$ \\
\hline $\mathrm{U}$ & 0.0013 \\
\hline
\end{tabular}

34. PNF. Waste used as feed for the partial neutralization campaigns conducted at the 242-S Evaporator during the late 1970s. Noncomplexed. For typical composition see No. 18 , evaporator feed (EF). 
35. PUREX Sludge Supernatant (PSS) Liquid. PUREX sludge supernatant liquid was produced by leaching PUREX sludge. This sludge, in underground storage, resulted from the neutralization of PUREX high-level waste and the removal of supernatant liquids.

Approximate Composition
\begin{tabular}{|l|l|}
\hline Element/isotope & mol/L \\
\hline $\mathrm{Al}$ & 0.04 \\
\hline $\mathrm{CO}_{3}$ & 0.24 \\
\hline $\mathrm{Cr}$ & 0.002 \\
\hline $\mathrm{Na}$ & 5.4 \\
\hline $\mathrm{NO}_{3}$ & 4.2 \\
\hline $\mathrm{NO}_{2}$ & 0.22 \\
\hline $\mathrm{SO}_{4}$ & 0.25 \\
\hline
\end{tabular}

36. $\underline{R}$. High-level waste from the REDOX process. $=2 \leq t+k$, Approximate Composition

\begin{tabular}{|l|l|}
\hline Element/isotope & $\mathrm{mol} / \mathrm{L}$ \\
\hline $\mathrm{Al}$ & 1.2 \\
\hline $\mathrm{Cr}$ & 0.177 \\
\hline $\mathrm{Fe}$ & 0.016 \\
\hline $\mathrm{Na}$ & 6.91 \\
\hline $\mathrm{NO}_{3}$ & 4.83 \\
\hline $\mathrm{OH}$ & 0.74 \\
\hline $\mathrm{PU}$ & $7.7 \mathrm{E}-7$ \\
\hline $\mathrm{SO}_{4}$ & 0.031 \\
\hline $\mathrm{U}$ & 0.0014 \\
\hline
\end{tabular}

37. RESD. A residual evaporator liquor. This is the same as HDRL, which in turn was formerly called TL. For composition see No. 44, Terminal Liquor (TL). 
38. REDOX Ion Exchange (RIX) Waste. Waste produced at B Plant after extraction of cesium from REDOX supernatant liquid by ion exchange. This includes column waste, column wash waste, and cesium purification waste.

Approximate Composition
\begin{tabular}{|l|l|}
\hline Element/isotope & mol/L \\
\hline $\mathrm{Al}$ & 0.6 \\
\hline $\mathrm{Na}$ & 3.1 \\
\hline $\mathrm{NO}_{3}$ & 1.97 \\
\hline $\mathrm{NO}_{2}$ & 0.27 \\
\hline $\mathrm{OH}$ & 0.69 \\
\hline $\mathrm{SO}_{4}$ & 0.022 \\
\hline
\end{tabular}

39. REDOX Supernatant (RSN). Supernatant liquor portion of waste generated by the REDOX process and found above sludge in underground storage tanks.

Approximate Composition
\begin{tabular}{|l|c|}
\hline Element/isotope & $\mathrm{mol} / \mathrm{L}$ \\
\hline $\mathrm{Al}$ & 0.59 \\
\hline $\mathrm{Na}$ & 5.2 \\
\hline $\mathrm{NO}_{2}$ & 0.18 \\
\hline $\mathrm{NO}_{3}$ & 3.08 \\
\hline $\mathrm{OH}$ & 1.26 \\
\hline $\mathrm{SO}_{4}$ & 0.015 \\
\hline
\end{tabular}

40. SIX. Waste resulting from the removal of cesium from PUREX sludge supernatant liquid (see waste type PSS) by ion exchange at the B Plant. The given composition includes column waste, wash waste, and cesium purification waste.

Approximate Composition
\begin{tabular}{|l|l|}
\hline Element/isotope & moll \\
\hline $\mathrm{Al}$ & 0.027 \\
\hline $\mathrm{CO}_{3}$ & 0.16 \\
\hline $\mathrm{Cr}$ & 0.0013 \\
\hline $\mathrm{Na}$ & 2.93 \\
\hline $\mathrm{NO}_{2}$ & 0.4 \\
\hline $\mathrm{NO}_{3}$ & 2.76 \\
\hline $\mathrm{SO}_{4}$ & 0.16 \\
\hline
\end{tabular}


41. Strontium Sludge (SRS). Sludge feed for the strontium extraction process at the B Plant. This waste type turned up during the mid-1970s and most likely originated largely from the PUREX process. Three compositions of PUREX sludges are given, two from sample analyses and one estimated from knowledge of essential material consumption and chemical behavior. The first waste composition is clearly labeled PUREX sludge but is not dated nor is a sampling method given. The third waste composition given here represents a homogenized core sample of the tank and may contain a variety of sludges. The one estimated composition contains less water than the actual compositions. The discrepancies between these three compositions reflect the difficulty of relying on a wide variety of sources to characterize highly variable waste types:

Composition of a Sampled

Sludge from Tank 241-C-106

\begin{tabular}{|l|l|}
\hline \multicolumn{1}{|c|}{ Element/isotope } & $\mathrm{mol} / \mathrm{L}$ \\
\hline $\mathrm{Al}^{*}$ & 1.95 \\
\hline $\mathrm{Ba}$ & $<0.04$ \\
\hline $\mathrm{Ca}^{*}$ & 0.2 \\
\hline $\mathrm{Fe}^{*}$ & 1.78 \\
\hline $\mathrm{Mg}$ & 0.09 \\
\hline $\mathrm{Mn}$ & 0.55 \\
\hline $\mathrm{Na}$ & 2.2 \\
\hline $\mathrm{OH}$ & 5.74 \\
\hline $\mathrm{Pu}$ & 0.00025 \\
\hline $\mathrm{Si} *$ & 0.136 \\
\hline
\end{tabular}

* Assuming $\mathrm{Al}$ present as

$\mathrm{NaAlO}_{2}, \mathrm{Fe}$ as $\mathrm{Fe}(\mathrm{OH})_{3}, \mathrm{Ca}$ as

$\mathrm{Ca}(\mathrm{OH})_{2}$, and $\mathrm{Si}$ as $\mathrm{Na}_{2} \mathrm{SiO}_{3}$.

Composition of a Composite of Sampled

Solids from Tank 241-C-106 Done in September 1976

\begin{tabular}{|l|l|}
\hline \multicolumn{1}{|c|}{ Element/isotope } & $\mathrm{mol} / \mathrm{L}$ \\
\hline $\mathrm{Al}$ & 2.11 \\
\hline $\mathrm{Ca}$ & 0.425 \\
\hline $\mathrm{Fe}$ & 1.33 \\
\hline $\mathrm{Mg}$ & 0.386 \\
\hline $\mathrm{Na}$ & 7.27 \\
\hline $\mathrm{P}$ & 0.13 \\
\hline $\mathrm{Si}$ & 3.61 \\
\hline TOC & $6.6 \mathrm{gm} / \mathrm{L}$ \\
\hline
\end{tabular}


PUREX Sludge Composition*

\begin{tabular}{|l|c|}
\hline \multicolumn{1}{|c|}{ Element/isotope } & $\mathrm{mol} / \mathrm{L}$ \\
\hline $\mathrm{Al}$ & 3.87 \\
\hline $\mathrm{Fe}$ & 2.75 \\
\hline $\mathrm{Mn}$ & 0.8 \\
\hline $\mathrm{Na}$ & 12.96 \\
\hline $\mathrm{OH}$ & 8.25 \\
\hline $\mathrm{PO}$ & 0.27 \\
\hline $\mathrm{Si}$ & 4.14 \\
\hline $\mathrm{Zr}$ & 1.1 \\
\hline
\end{tabular}

* This is a theoretical PUREX sludge composition based on known consumption of essential materials and known solubility behavior of ionic species.

42. Strontium Semiworks Waste (SSW). Waste produced from the strontium extraction process at the strontium semiworks after 1961. Feed was typically PUREX high-level acid waste.

Approximate Composition

\begin{tabular}{|l|l|}
\hline \multicolumn{1}{|c|}{ Element/isotope } & $\mathrm{mol} / \mathrm{L}$ \\
\hline $\mathrm{Ba}$ & 0.0002 \\
\hline $\mathrm{Ca}$ & 0.0049 \\
\hline $\mathrm{Ce}$ & 0.0017 \\
\hline $\mathrm{C}_{2} \mathrm{H}_{3} \mathrm{O}_{2}$ (acetate) & 1.34 \\
\hline $\mathrm{Fe}$ & 0.03 \\
\hline $\mathrm{K}$ & 0.078 \\
\hline $\mathrm{Na}$ & 4.9 \\
\hline $\mathrm{NO}{ }_{3}$ & 2.1 \\
\hline $\mathrm{OH}$ & 1.32 \\
\hline $\mathrm{Pb}$ & 0.034 \\
\hline $\mathrm{RE}$ & 0.0069 \\
\hline $\mathrm{Sr}$ & 0.0005 \\
\hline
\end{tabular}


43. TBP. Waste from the TBP uranium-extraction process at U Plant, composed of concentrated, neutralized aqueous effluents from the primary extraction column and from the solvent wash.

Approximate Composition

\begin{tabular}{|l|l|}
\hline Element/isotope & $\mathrm{mol} / \mathrm{L}$ \\
\hline $\mathrm{Cl}$ & 0.0025 \\
\hline $\mathrm{Fe}$ & 0.03 \\
\hline $\mathrm{Na}$ & 8.87 \\
\hline $\mathrm{NO}_{3}$ & 7.35 \\
\hline $\mathrm{OH}$ & 0.09 \\
\hline $\mathrm{PO}_{4}$ & 0.3 \\
\hline $\mathrm{Pu}$ & $6.7 \mathrm{E}-7$ \\
\hline $\mathrm{SO}_{4}$ & 0.31 \\
\hline $\mathrm{U}$ & 0.0061 \\
\hline
\end{tabular}

44. Terminal Liquor (TL). Terminal liquor produced by evaporators as a concentrated supernatant liquid decanted from the evaporator bottoms. Terminal liquor is defined as evaporator liquor that may not be evaporated further without producing solids that are unsatisfactory for storage in SSTs. These undesirable solids may be either deliquescent caustic salts, fine and poorly draining aluminate solids, or gelled organic complexants.

Typical Composition

\begin{tabular}{|l|l|}
\hline Element/isotope & $\mathrm{mol} / \mathrm{L}$ \\
\hline $\mathrm{Al}$ & 2.3 \\
\hline $\mathrm{CO}_{3}$ & 0.2 \\
\hline $\mathrm{Na}$ & 12.6 \\
\hline $\mathrm{NO}_{2}$ & 3.0 \\
\hline $\mathrm{NO}_{3}$ & 2.5 \\
\hline $\mathrm{OH}$ & 4.4 \\
\hline $\mathrm{PO}_{4}$ & 0.001 \\
\hline
\end{tabular}


45. 1C. First decontamination cycle waste from the $\mathrm{BiPO}_{4}$ process at $\mathrm{B}$ and $\mathrm{T}$ Plants. This waste type consists of byproducts coprecipitated from a plutonium-containing solution. Coating waste from the removal of aluminum fuel element cladding was added and composed about $24 \%$ of this waste stream.

Approximate Composition

\begin{tabular}{|l|l|}
\hline Element/isotope & \multicolumn{1}{|c|}{$\mathrm{mol} / \mathrm{L}$} \\
\hline $\mathrm{Al}$ & 0.38 \\
\hline $\mathrm{Bi}$ & 0.012 \\
\hline $\mathrm{Ce}$ & 0.00022 \\
\hline $\mathrm{Cr}$ & 0.0016 \\
\hline $\mathrm{F}$ & 0.19 \\
\hline $\mathrm{Fe}$ & 0.025 \\
\hline $\mathrm{Na}$ & 3.34 \\
\hline $\mathrm{NO}$ & 0.28 \\
\hline $\mathrm{NO}_{3}$ & 1.54 \\
\hline $\mathrm{OH}$ & 0.28 \\
\hline $\mathrm{PO}_{4}$ & 0.28 \\
\hline $\mathrm{PU}$ & 0.000002 \\
\hline $\mathrm{Si}$ & 0.034 \\
\hline $\mathrm{SO}_{4}$ & 0.052 \\
\hline
\end{tabular}

46. 2C. Waste from the second decontamination cycle of the $\mathrm{BiPO}_{4}$ process at $\mathrm{B}$ and $\mathrm{T}$ Plants and consisting of effluent remaining after precipitation of plutonium product.

\begin{tabular}{|l|l|}
\multicolumn{2}{|c|}{ Approximate Composition } \\
\hline Element/isotope & $\mathrm{mol} / \mathrm{L}$ \\
\hline $\mathrm{Bi}$ & 0.0092 \\
\hline $\mathrm{Cr}$ & 0.0025 \\
\hline $\mathrm{F}$ & 0.22 \\
\hline $\mathrm{Fe}$ & 0.023 \\
\hline $\mathrm{Na}$ & 2.04 \\
\hline $\mathrm{NO}_{3}$ & 1.27 \\
\hline $\mathrm{PO}_{4}$ & 0.34 \\
\hline $\mathrm{Si}$ & 0.037 \\
\hline $\mathrm{SO}_{4}$ & 0.062 \\
\hline
\end{tabular}


47. 224. Waste from the final decontamination and concentration stage of the $\mathrm{BiPO}_{4}$ process. In this stage, first the byproducts and finally the plutonium product are precipitated with lanthanum fluoride. This waste was largely sent into the ground through reverse flow wells and underground sumps.

\section{Approximate Composition}

\begin{tabular}{|l|l|}
\hline Element/isotope & $\mathrm{mol} / \mathrm{L}$ \\
\hline $\mathrm{Bi}$ & 0.0062 \\
\hline $\mathrm{Cr}$ & 0.0009 \\
\hline $\mathrm{F}$ & 0.31 \\
\hline $\mathrm{H}_{2} \mathrm{C}_{2} \mathrm{O}_{4}$ (oxalate) & 0.028 \\
\hline $\mathrm{K}$ & 0.26 \\
\hline $\mathrm{La}$ & 0.0014 \\
\hline $\mathrm{Mn}$ & 0.0046 \\
\hline $\mathrm{Na}$ & 1.75 \\
\hline $\mathrm{NO}_{3}$ & 1.06 \\
\hline $\mathrm{OH}$ & 0.59 \\
\hline $\mathrm{PO}_{4}$ & 0.049 \\
\hline
\end{tabular}

48. 5-6. Waste from Tank 5-6 at B Plant. This is a very hot waste that collected in the bottom of Section 5 at B Plant due to boil-over during dissolving and neutralization during the $\mathrm{BiPO}_{4}$ process. 
49. $\quad$ Z. Waste discharged from the Plutonium Finishing Plant during the late 1970 s.

Waste from the Plutonium Reclamation Facility and the Remote Mechanical C Line was sent to evaporators and put in SSTs. At times, slag and crucibles from processing of plutonium metal were used as feed material for plutonium reclamation, changing the waste composition.

Approximate Composition Without Slag and Crucible Processing

\begin{tabular}{|l|l|}
\hline \multicolumn{1}{|c|}{ Element/isotope } & $\mathrm{mol} / \mathrm{L}$ \\
\hline $\mathrm{Al}$ & 0.5 \\
\hline $\mathrm{Ba}$ & 0.000003 \\
\hline $\mathrm{Ca}$ & 0.00071 \\
\hline $\mathrm{Cr}$ & 0.0014 \\
\hline $\mathrm{Fe}$ & 0.0007 \\
\hline $\mathrm{K}$ & 0.0007 \\
\hline $\mathrm{Mg}$ & 0.000021 \\
\hline $\mathrm{Mn}$ & 0.0007 \\
\hline $\mathrm{Na}$ & 4 \\
\hline $\mathrm{Ni}$ & 0.00057 \\
\hline $\mathrm{Pb}$ & 0.00036 \\
\hline $\mathrm{Sr}$ & 0.000021 \\
\hline $\mathrm{OH}$ & 0.0001 \\
\hline $\mathrm{Cl}$ & 0.041 \\
\hline $\mathrm{F}$ & 0.047 \\
\hline $\mathrm{NO}{ }_{3}$ & 3.5 \\
\hline $\mathrm{NO}{ }_{2}$ & 0.014 \\
\hline $\mathrm{PO}$ & 0.00014 \\
\hline $\mathrm{SO}{ }_{4}$ & 0.0014 \\
\hline $\mathrm{TRU}$ & $\mathrm{g} / \mathrm{L}$ \\
\hline $\mathrm{U}$ & \\
\hline $\mathrm{TOC}$ & 00006 \\
\hline & \\
\hline
\end{tabular}


Approximate Composition with

Slag and Crucible Processing

(where different from above)

\begin{tabular}{|l|l|}
\hline Element/isotope & $\mathrm{mol} / \mathrm{L}$ \\
\hline $\mathrm{Ca}$ & 0.014 \\
\hline $\mathrm{Fe}$ & 0.0071 \\
\hline $\mathrm{F}$ & 0.018 \\
\hline $\mathrm{I}$ & 0.00016 \\
\hline $\mathrm{NO}_{2}$ & 0.0065 \\
\hline
\end{tabular}


$$
\text { . }
$$ 


\section{Appendix C}

Core Sample Analytical Data Tables Used in the SORWT Model Verification Study 
Data Set Used in Verification Study

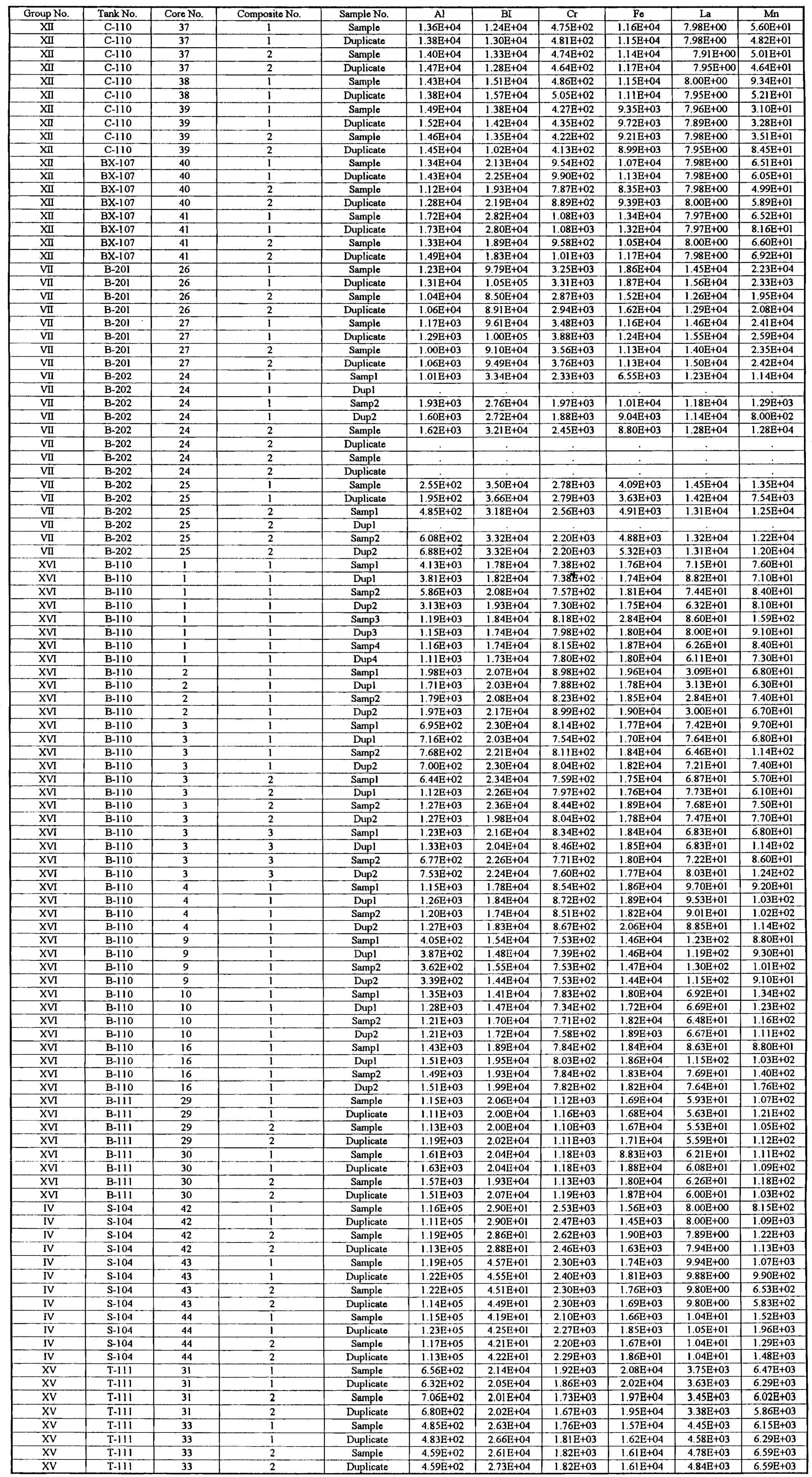


Data Set Used in Verification Study

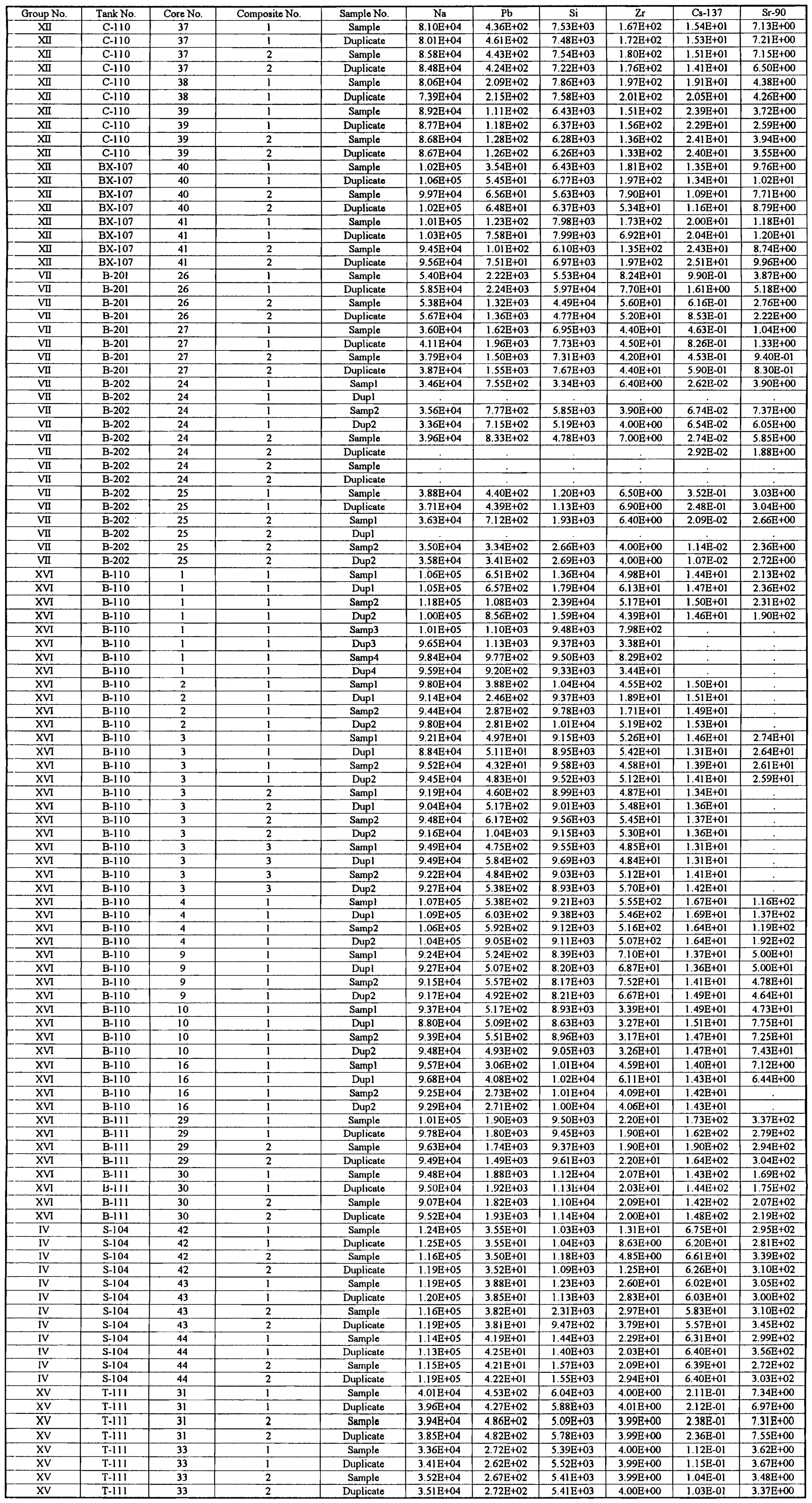


Data Set Used in Verification Study

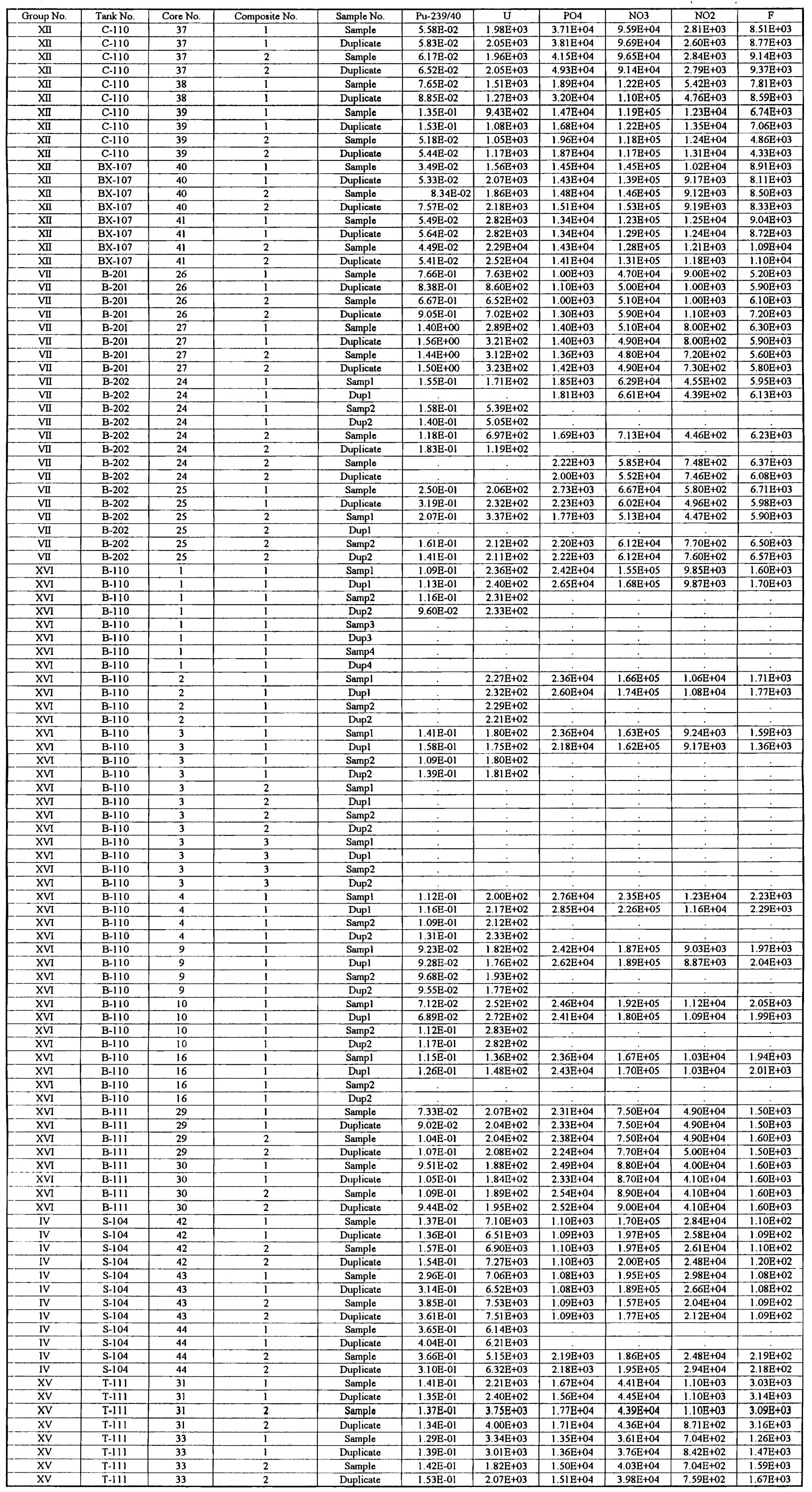


Data Set used in Verification Study

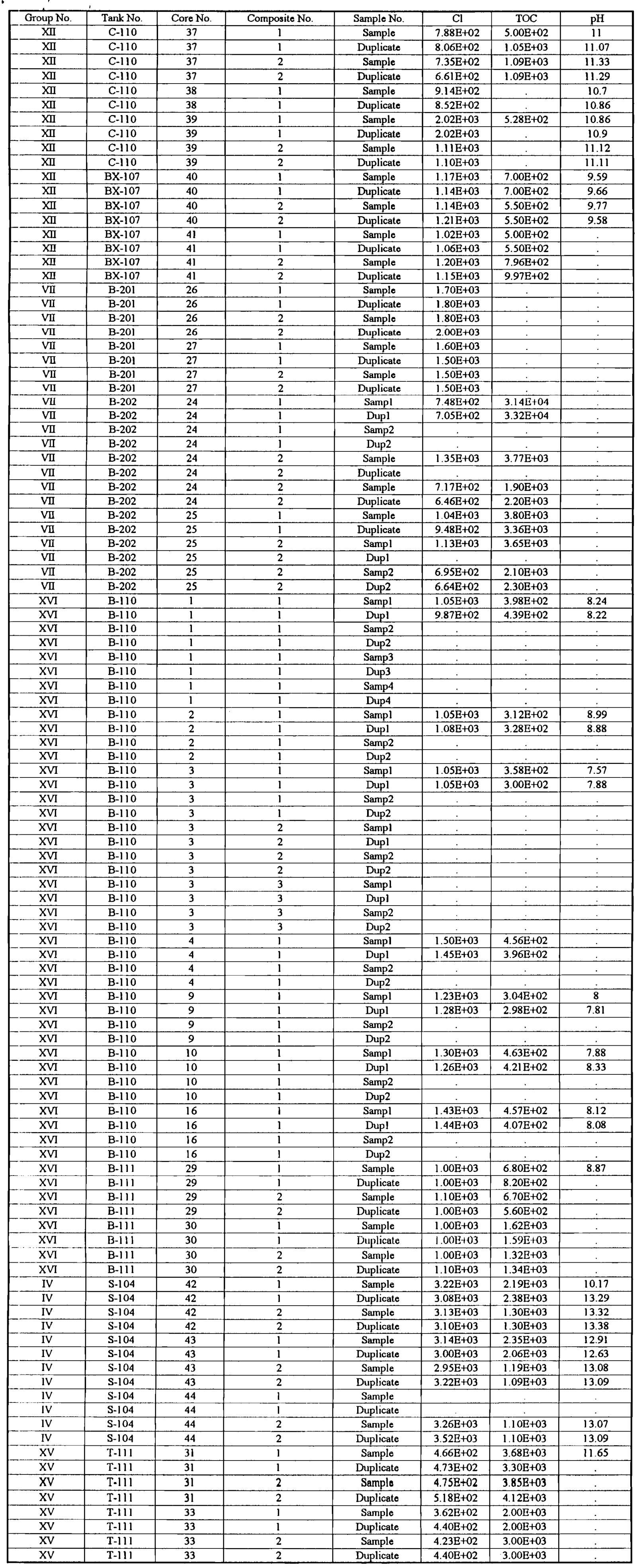


Data Set Used in Verification Study

\begin{tabular}{|c|c|c|}
\hline Group No. & Tank No. & Density \\
\hline XII & BX-107 & 1.47 \\
\hline$\overline{X I I}$ & $B \times-107$ & 1.45 \\
\hline XII & BX-107 & 1.4 \\
\hline XII & C-110 & 1.18 \\
\hline XII & C-110 & 1.21 \\
\hline XII & C-110 & 1 \\
\hline XII & C.110 & 1.34 \\
\hline XII & $c-110$ & 1.24 \\
\hline VII & B-201 & 1.25 \\
\hline VII & B-201 & 1.3 \\
\hline vil & B-201 & $1 . \overline{4}$ \\
\hline VII & B-201 & 1.2 \\
\hline VII & B-201 & 1.2 \\
\hline VII & B-201 & 1.2 \\
\hline VII & B-201 & 1.3 \\
\hline VII & B-201 & 1.3 \\
\hline VII & B-201 & 1.3 \\
\hline VII & B-201 & 1.2 \\
\hline VII & B-201 & 1.2 \\
\hline VII & B-201 & 1.2 \\
\hline VII & B-201 & 1.2 \\
\hline VII & B-201 & 1.3 \\
\hline VII & B-201 & 1.3 \\
\hline VII & B-201 & 1.2 \\
\hline VII & B-201 & 1.3 \\
\hline VII & B-202 & 1.01 \\
\hline VII & B-202 & 1.02 \\
\hline VII & B-202 & 0.94 \\
\hline VII & B-202 & 1.35 \\
\hline $\mathrm{VII}$ & B-202 & 1.3 \\
\hline VII & B-202 & 1.1 \\
\hline VII & B-202 & 1.13 \\
\hline VII & B-202 & 0.87 \\
\hline VII & B-202 & 1.08 \\
\hline Vll & B-202 & 1.02 \\
\hline VII & $\mathrm{B}-202$ & 1.09 \\
\hline VII & B-202 & 1.08 \\
\hline VII & B-202 & 0.92 \\
\hline VII & B-202 & 1.08 \\
\hline VII & B-202 & 1.13 \\
\hline XVII & B-110 & 1.29 \\
\hline XVII & B-110 & 1.28 \\
\hline XVII & B-110 & 1.31 \\
\hline XVII & B-110 & 1.3 \\
\hline XVII & B-110 & 1.21 \\
\hline XVII & B-110 & 1.47 \\
\hline XVII & B-110 & 1.25 \\
\hline$x$ VII & B-110 & 1.17 \\
\hline XVII & B-110 & 1.37 \\
\hline XVII & B-110 & 1.36 \\
\hline XVII & B-110 & 1.3 \\
\hline XVII & B-110 & 1.3 \\
\hline XVII & B-110 & 1.3 \\
\hline XVII & B-110 & 1.3 \\
\hline XVII & B-110 & 1.3 \\
\hline XVII & B-110 & 1.3 \\
\hline XVII & B- 110 & 1.3 \\
\hline$x$ XiI & B-110 & 1.3 \\
\hline XVII & B-110 & 1.24 \\
\hline XVII & B-110 & 1.24 \\
\hline XVII & B-110 & 1.29 \\
\hline XVII & B-110 & 1.28 \\
\hline XVII & B-110 & 1.28 \\
\hline XVII & B-110 & 1.3 \\
\hline XVII & B-110 & 1.3 \\
\hline XVII & B-110 & 1.3 \\
\hline XVII & B-110 & 1.3 \\
\hline XVII & $B-110$ & 1.3 \\
\hline XVII & B-111 & 1.2 \\
\hline XVII & B-111 & 1.2 \\
\hline XVII & B-111 & 1.3 \\
\hline XVII & B-111 & 1.3 \\
\hline XVII & B-111 & 0.9 \\
\hline XVII & B-111 & 1.3 \\
\hline XVII & B-111 & 1.3 \\
\hline XVII & B-111 & 1 \\
\hline IV & S-104 & 1.64 \\
\hline $\mathrm{XV}$ & T.111 & 1.19 \\
\hline$X V$ & $T \cdot 111$ & 1.28 \\
\hline
\end{tabular}




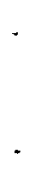




\section{Appendix D}

Box Plots of Core Sample Analytical Data Used in the SORWT Model Verification Study 



\section{Box Plot of Al Concentrations in SORWT Groups}

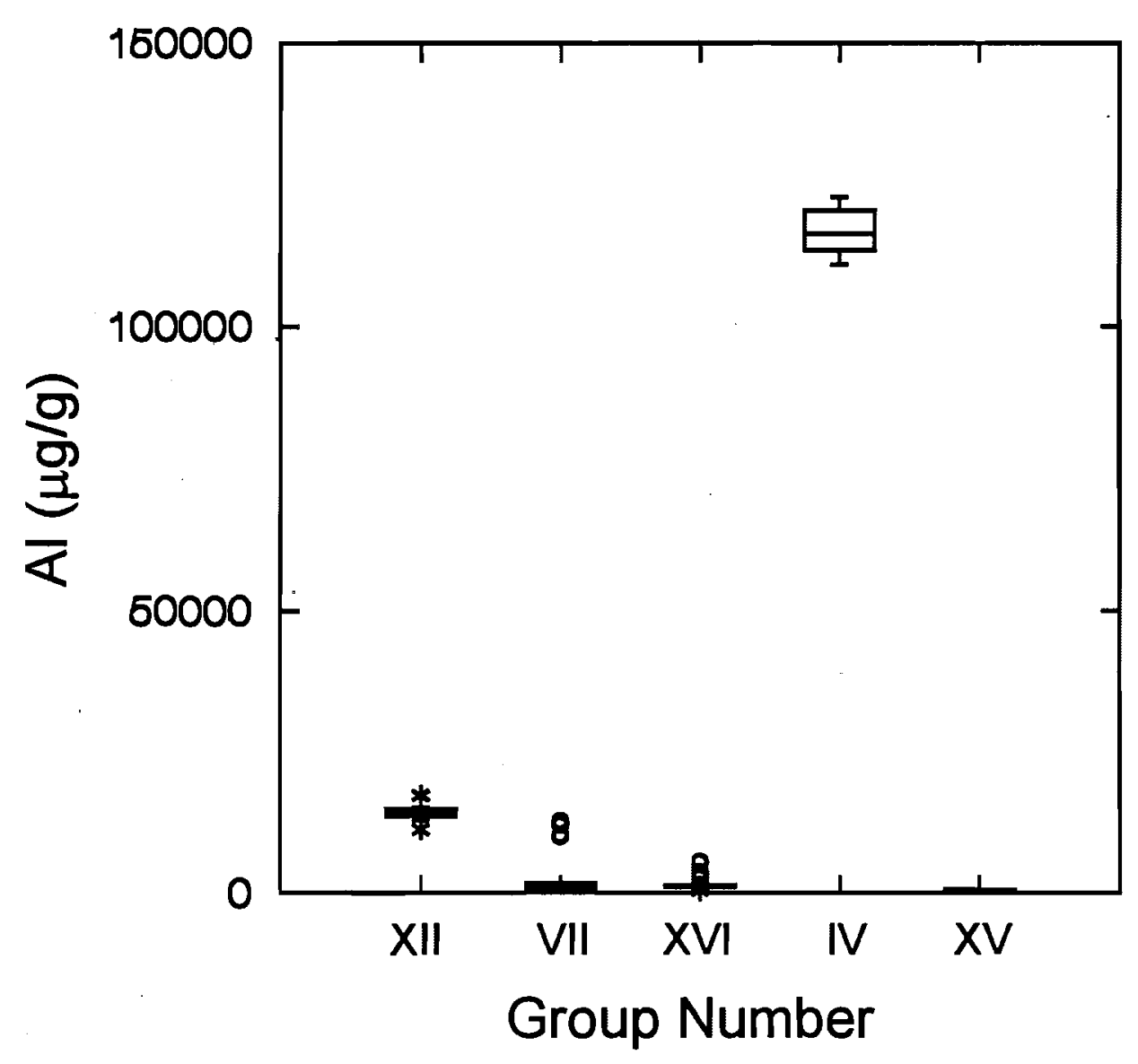

D. 1

PNL-9814 Rev 2 


\section{Box Plot of Bi Concentrations in SORWT Groups}

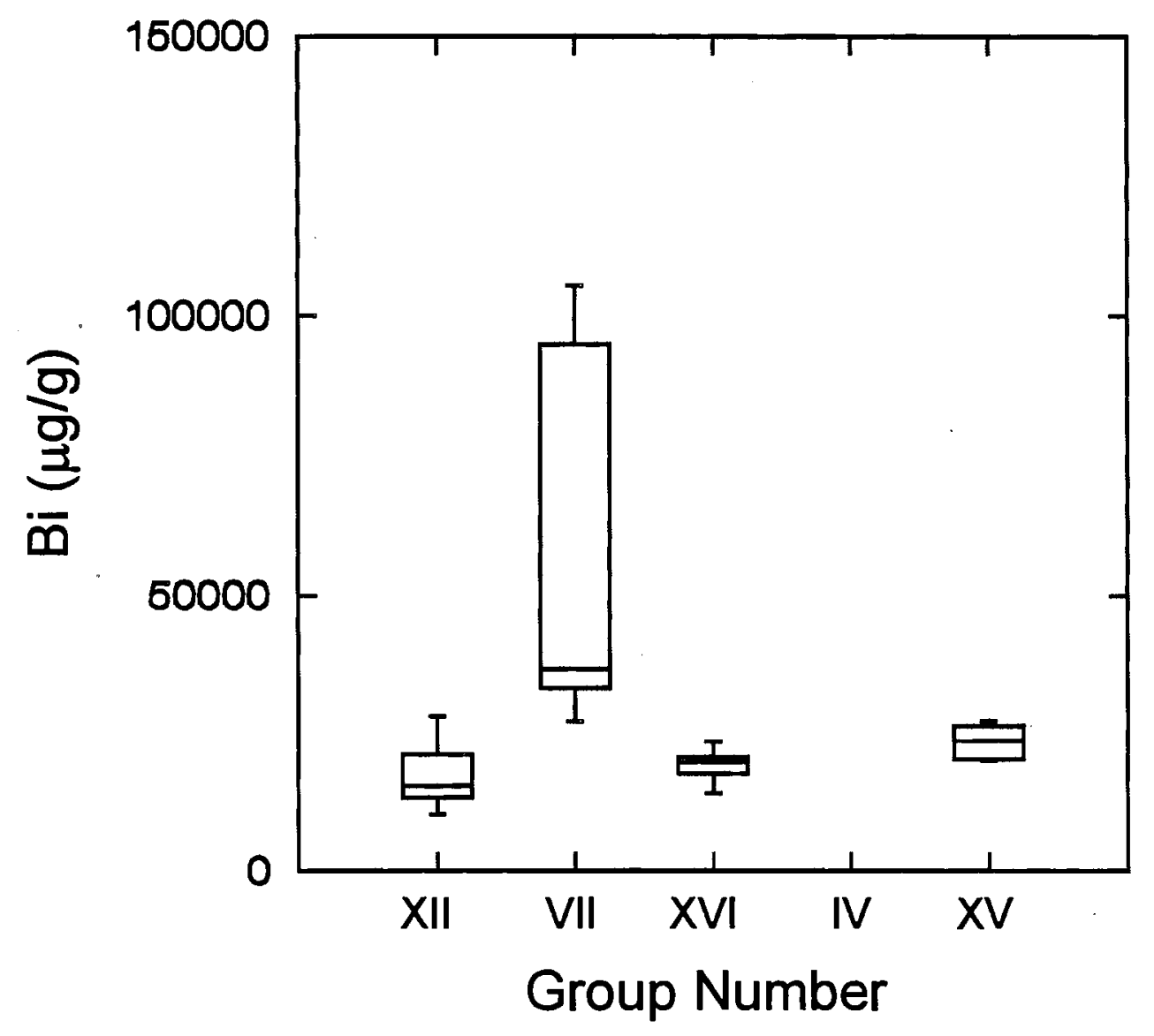

D. 2 


\section{Box Plot of $\mathrm{Cr}$ Concentrations in SORWT Groups}

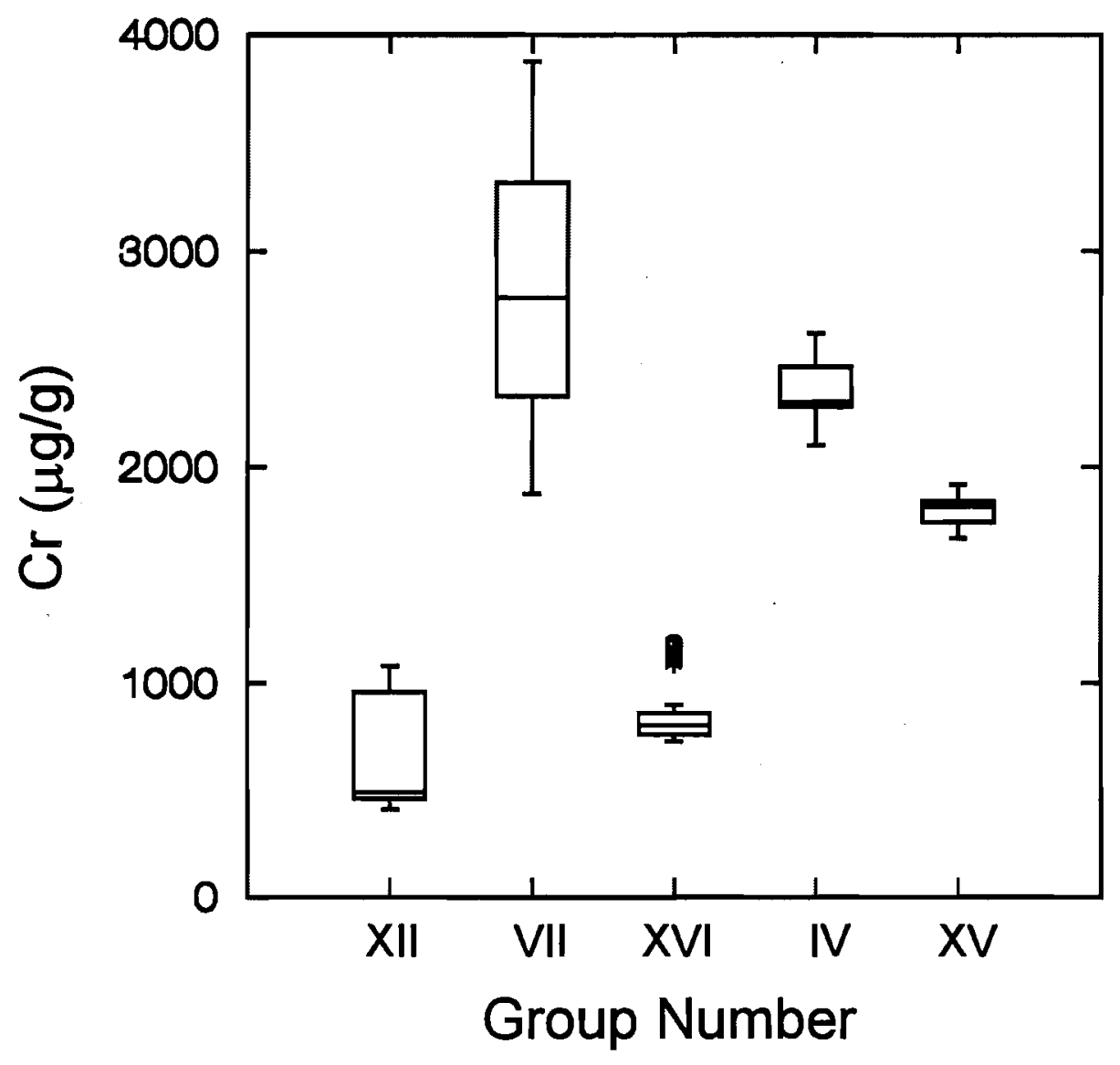

D.3

PNL-9814 Rev 2 


\section{Box Plot of Fe Concentrations in SORWT Groups}

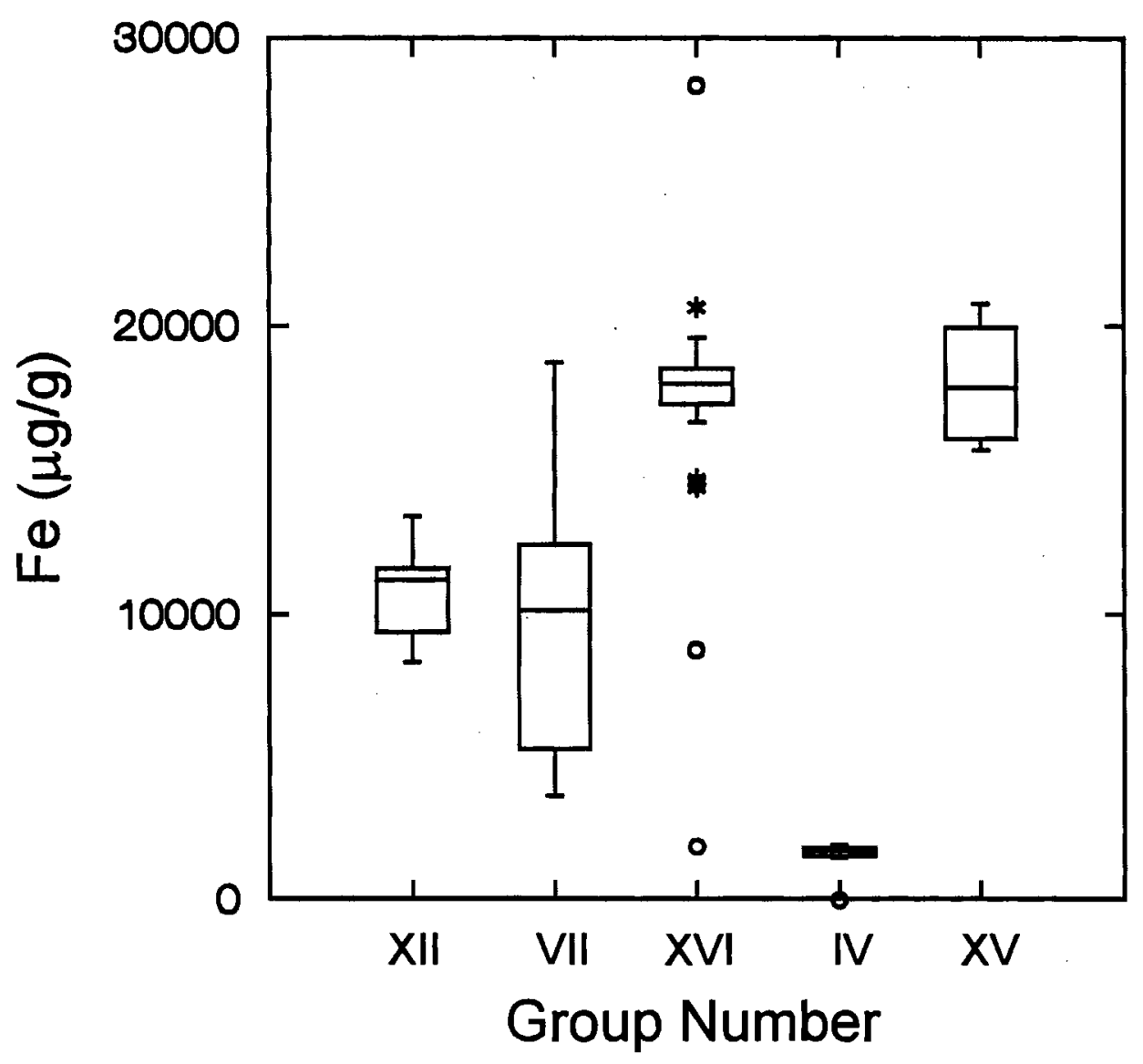




\section{Box Plot of La Concentrations in SORWT Groups}

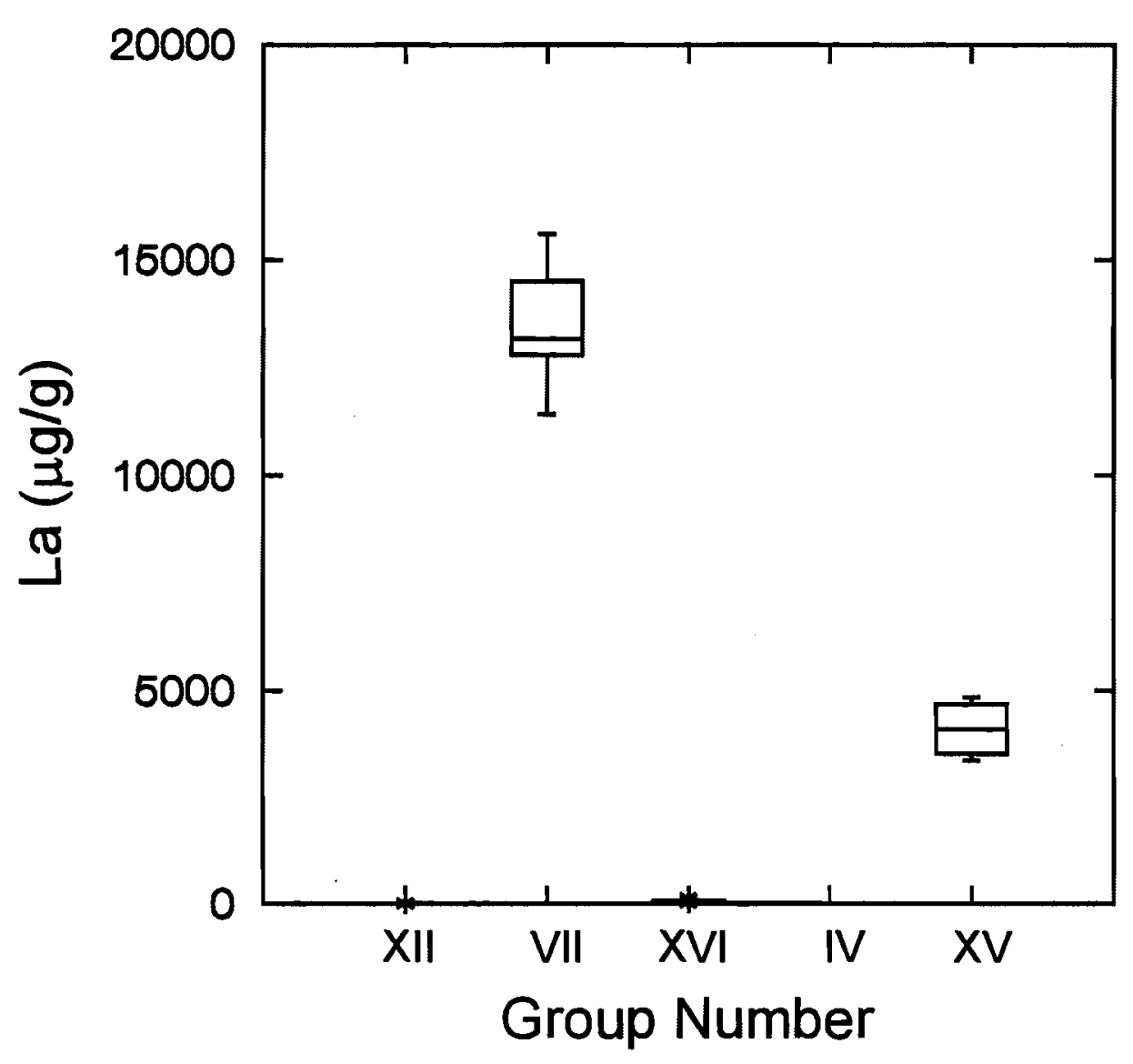

D.5 


\section{Box Plot of Mn Concentrations in SORWT Groups}

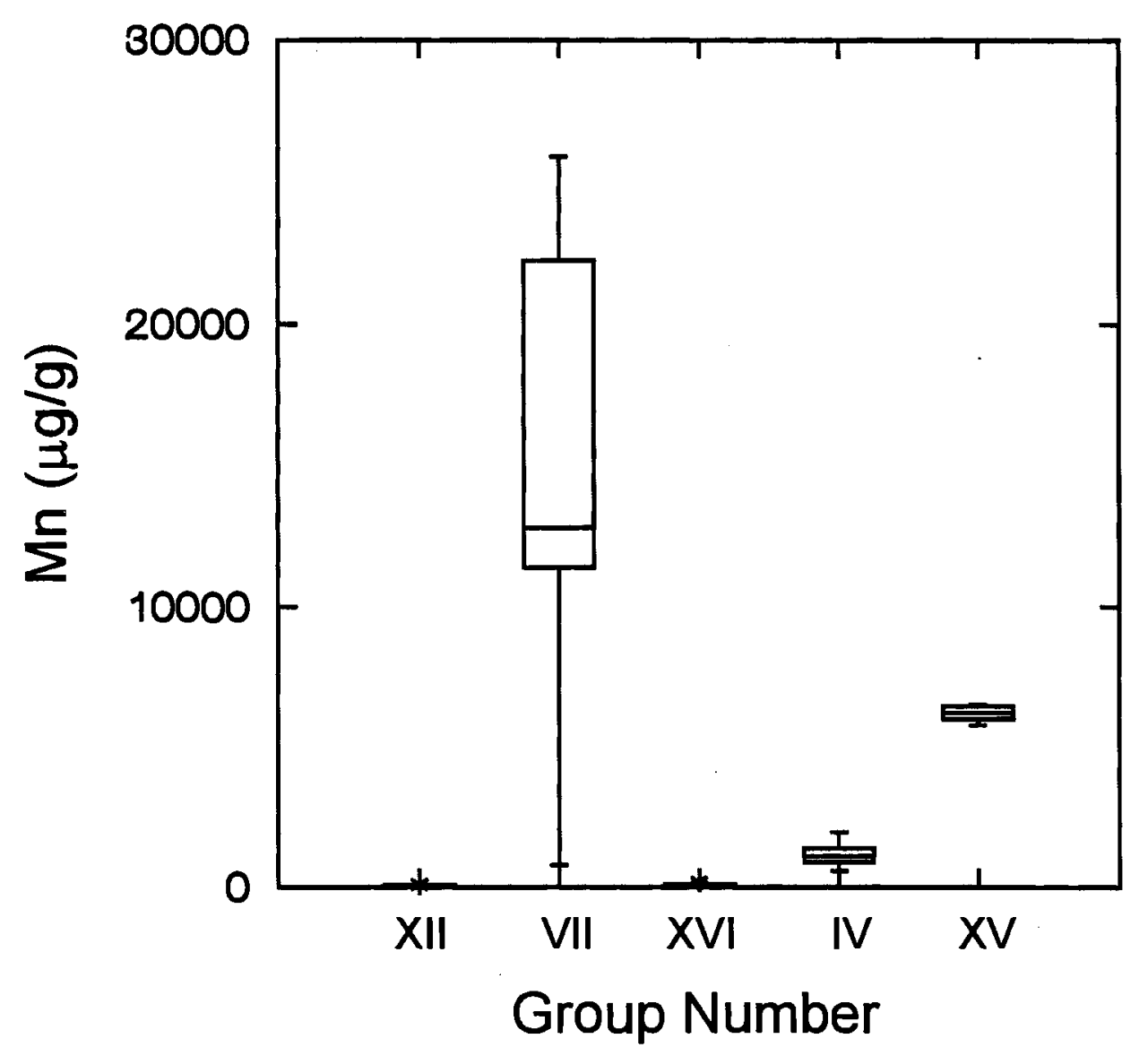

D.6 
Box Plot of $\mathrm{Na}$ Concentrations in SORWT Groups

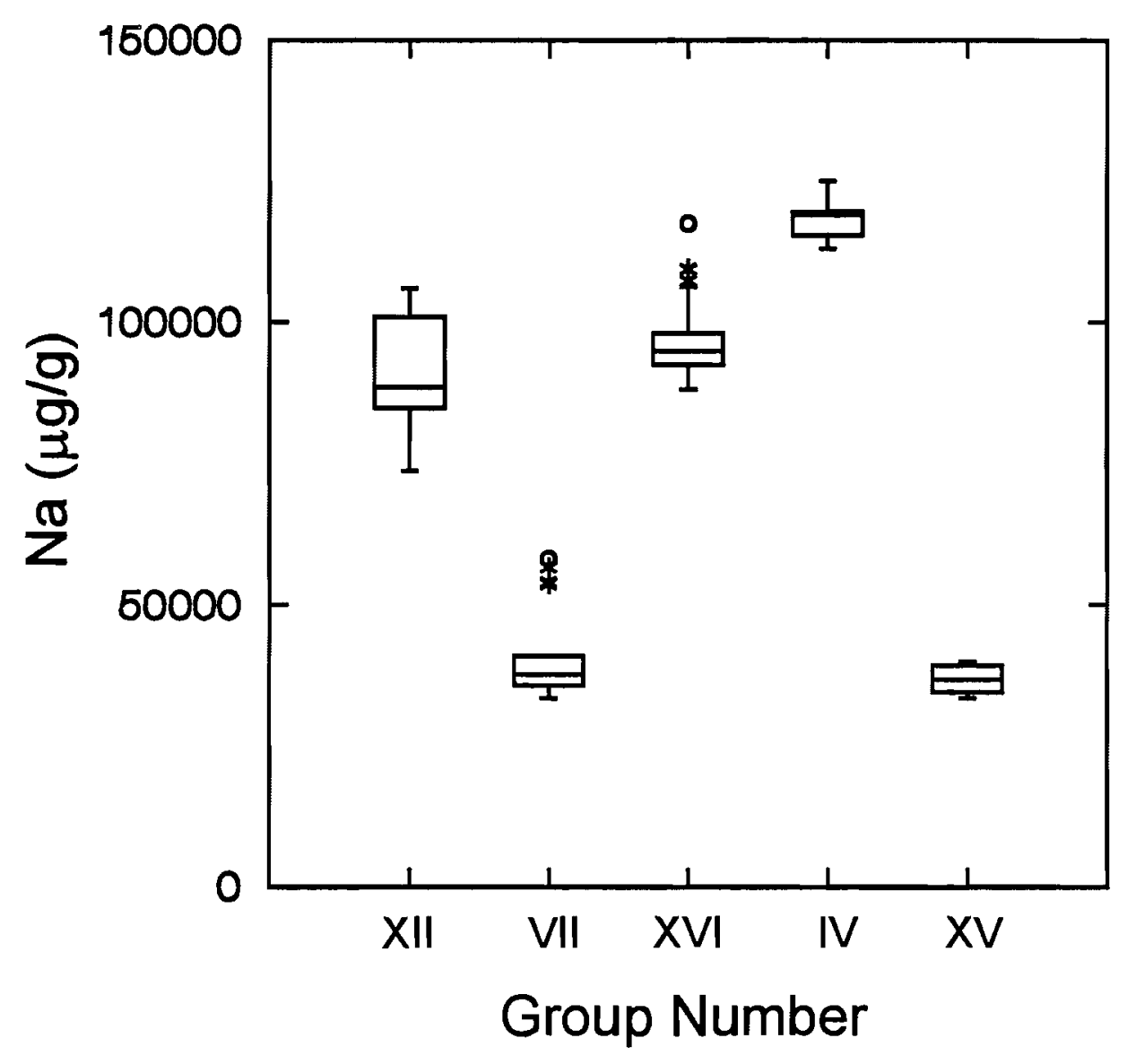

D.7 


\section{Box Plot of $\mathrm{Pb}$ Concentrations in SORWT Groups}

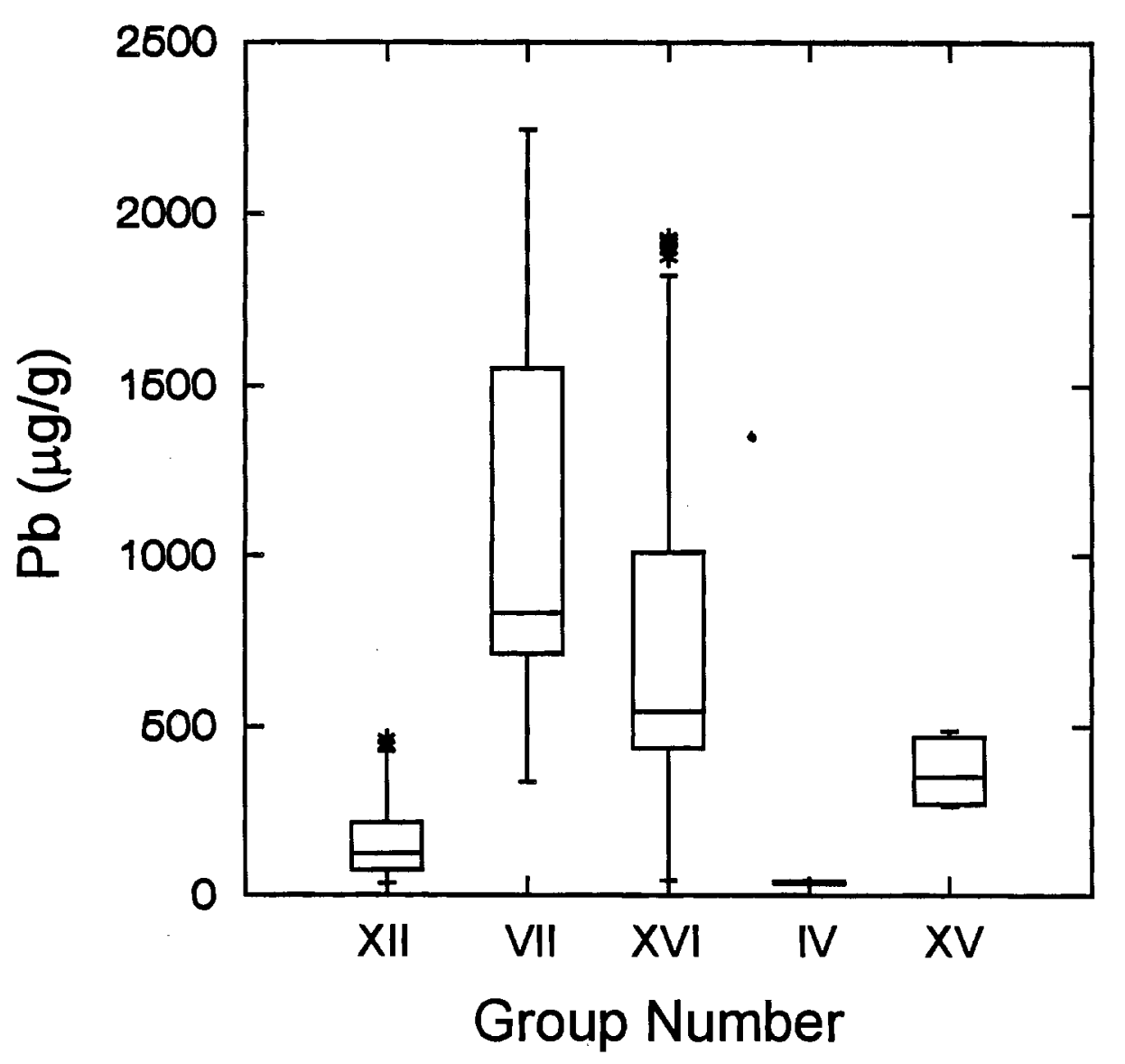

D. 8 


\section{Box Plot of Si Concentrations in SORWT Groups}

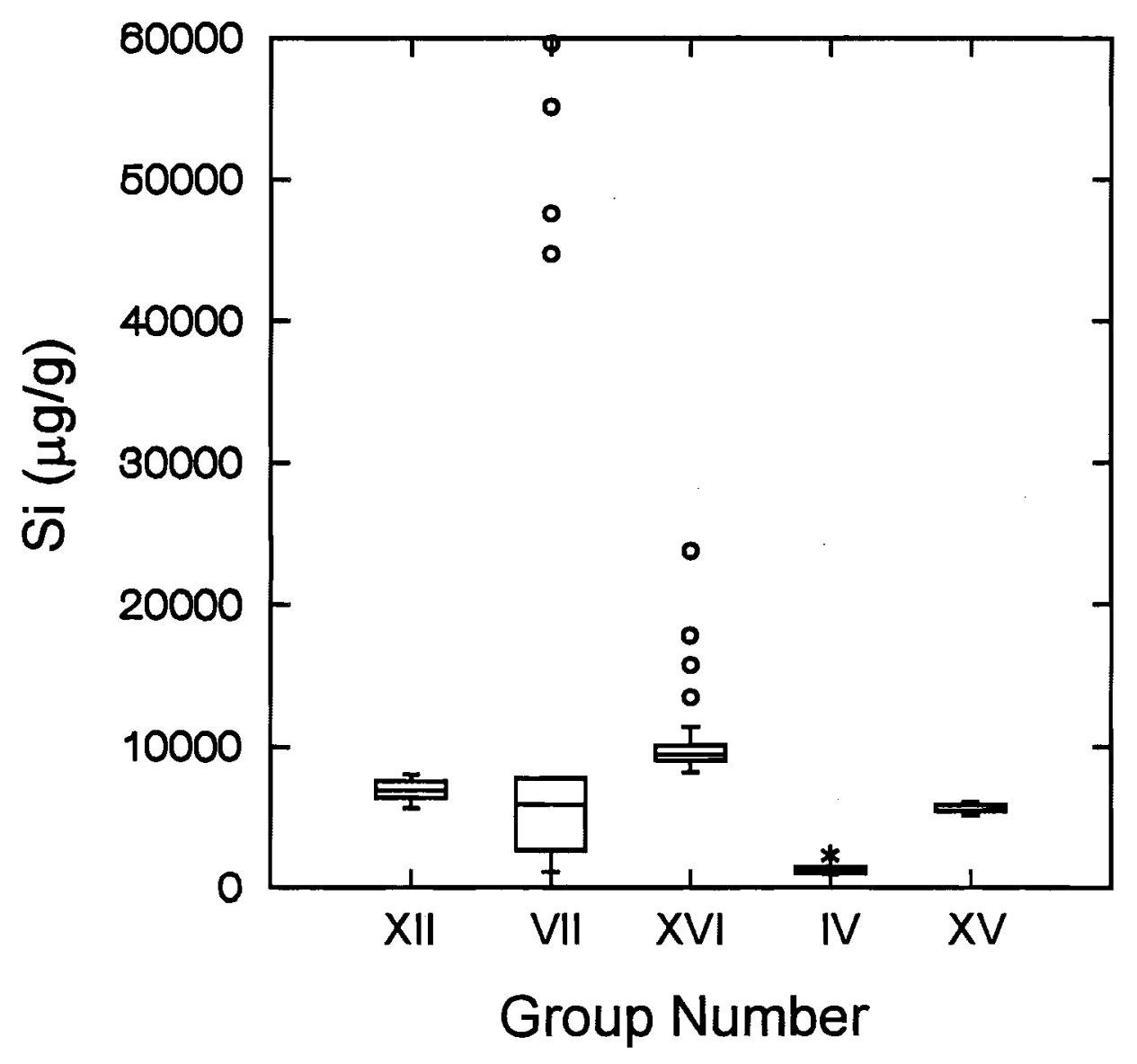

D.9 


\section{Box Plot of Zr Concentrations in SORWT Groups}

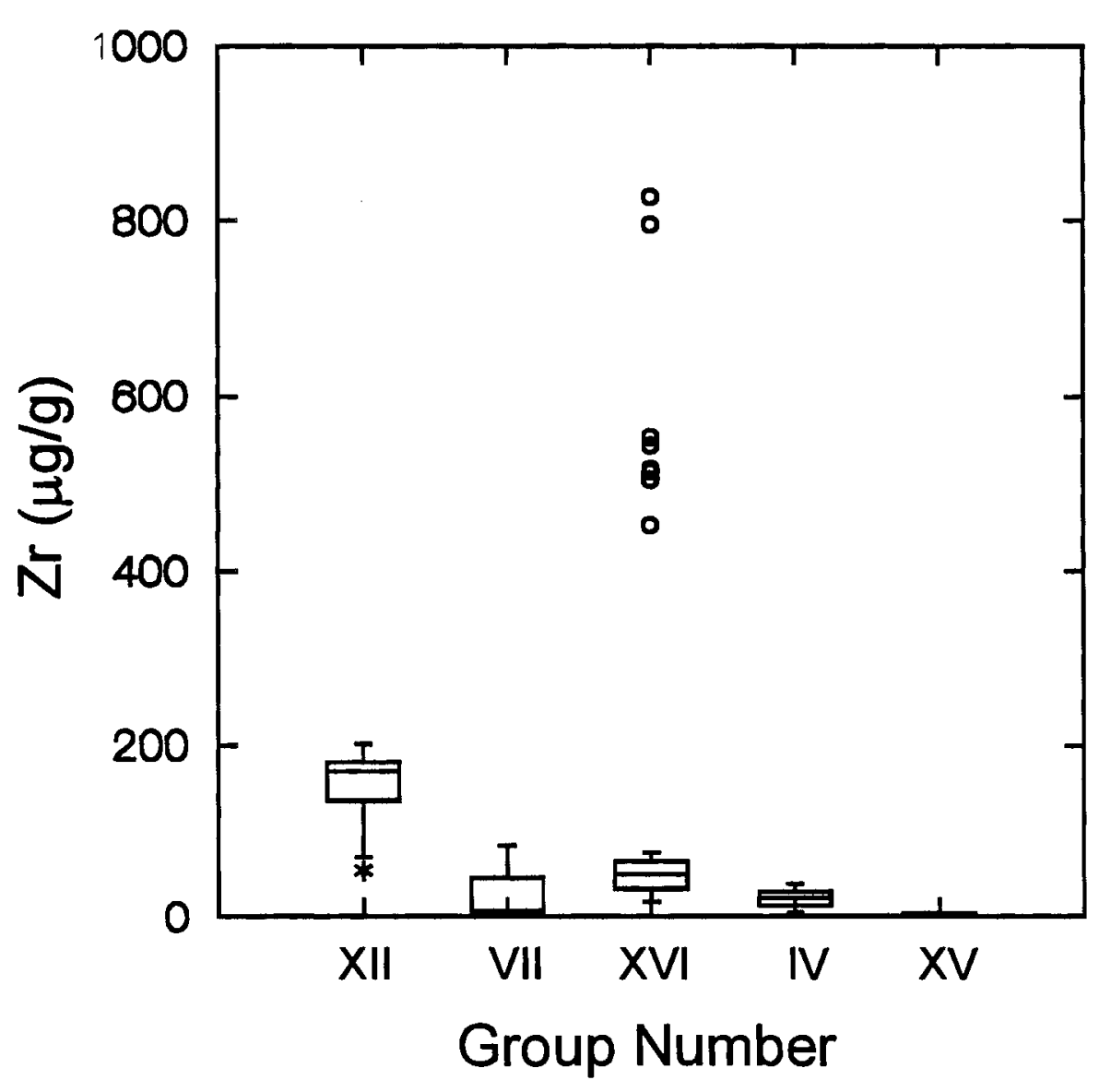




\section{Box Plot of Cs137 Concentrations in SORWT Groups}

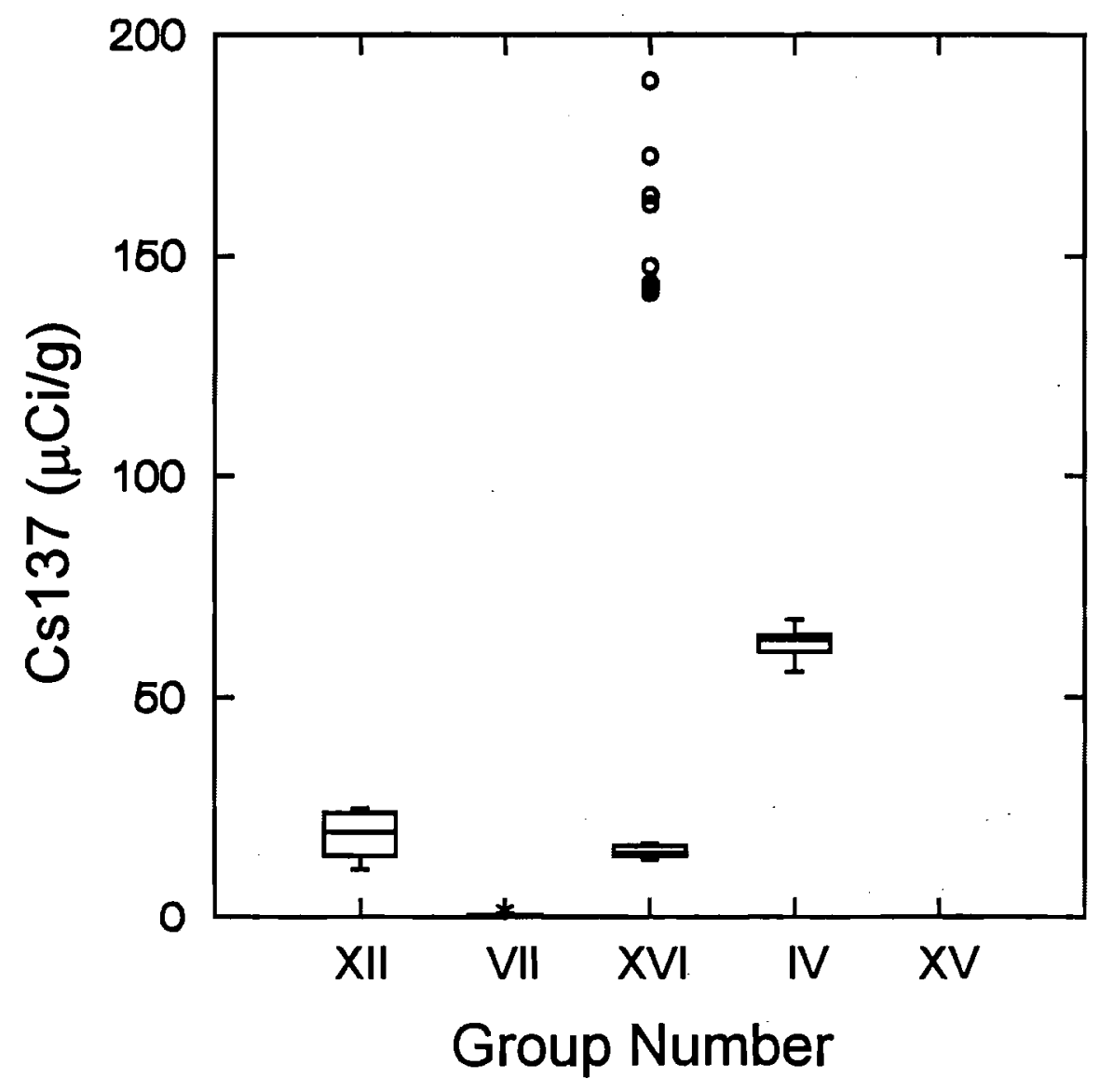




\section{Box Plot of Sr90 Concentrations in SORWT Groups}

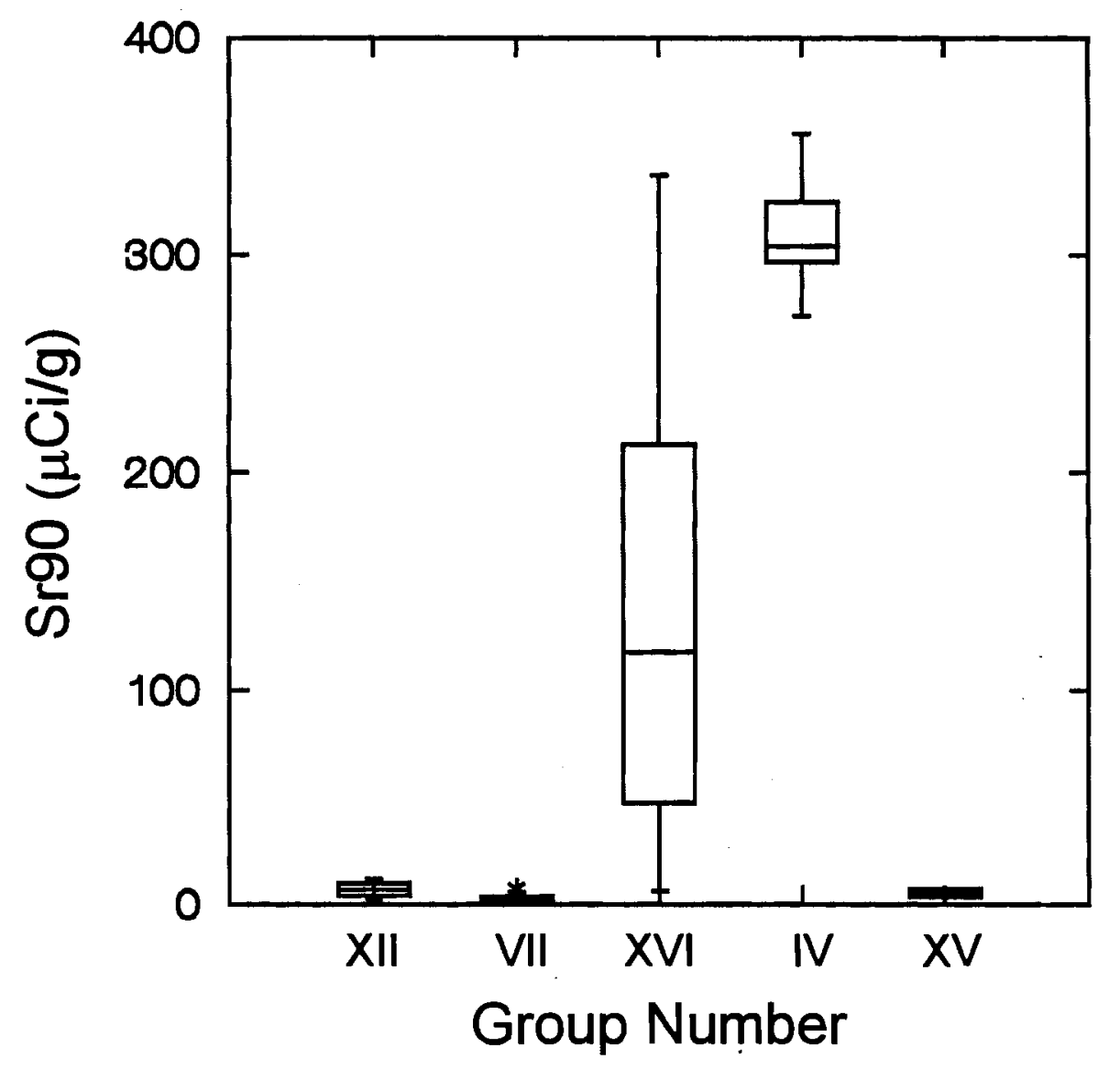


Box Plot of Pu239/240 Concentrations in SORWT Groups

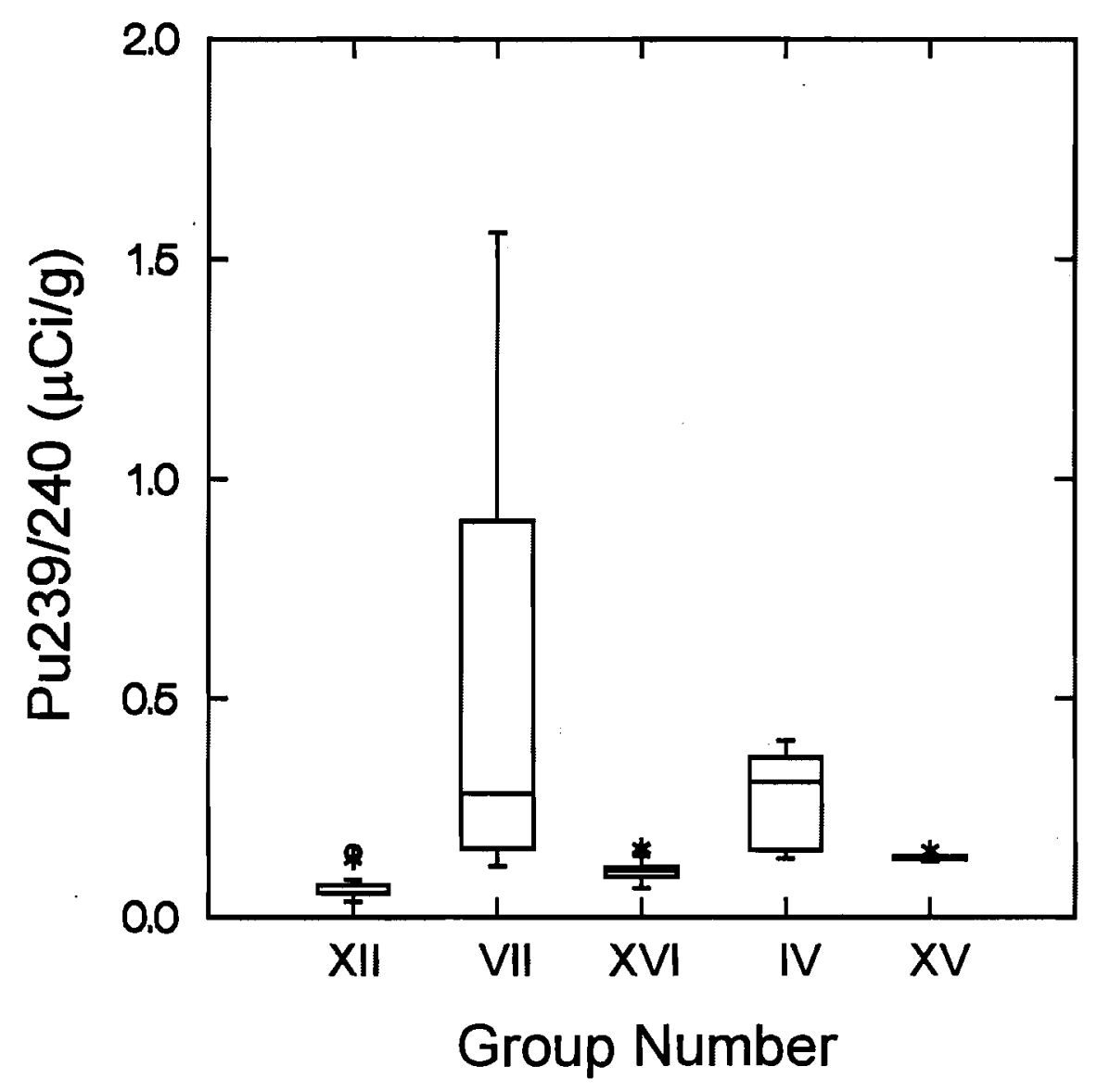




\section{Box Plot of U Concentrations in SORWT Groups}

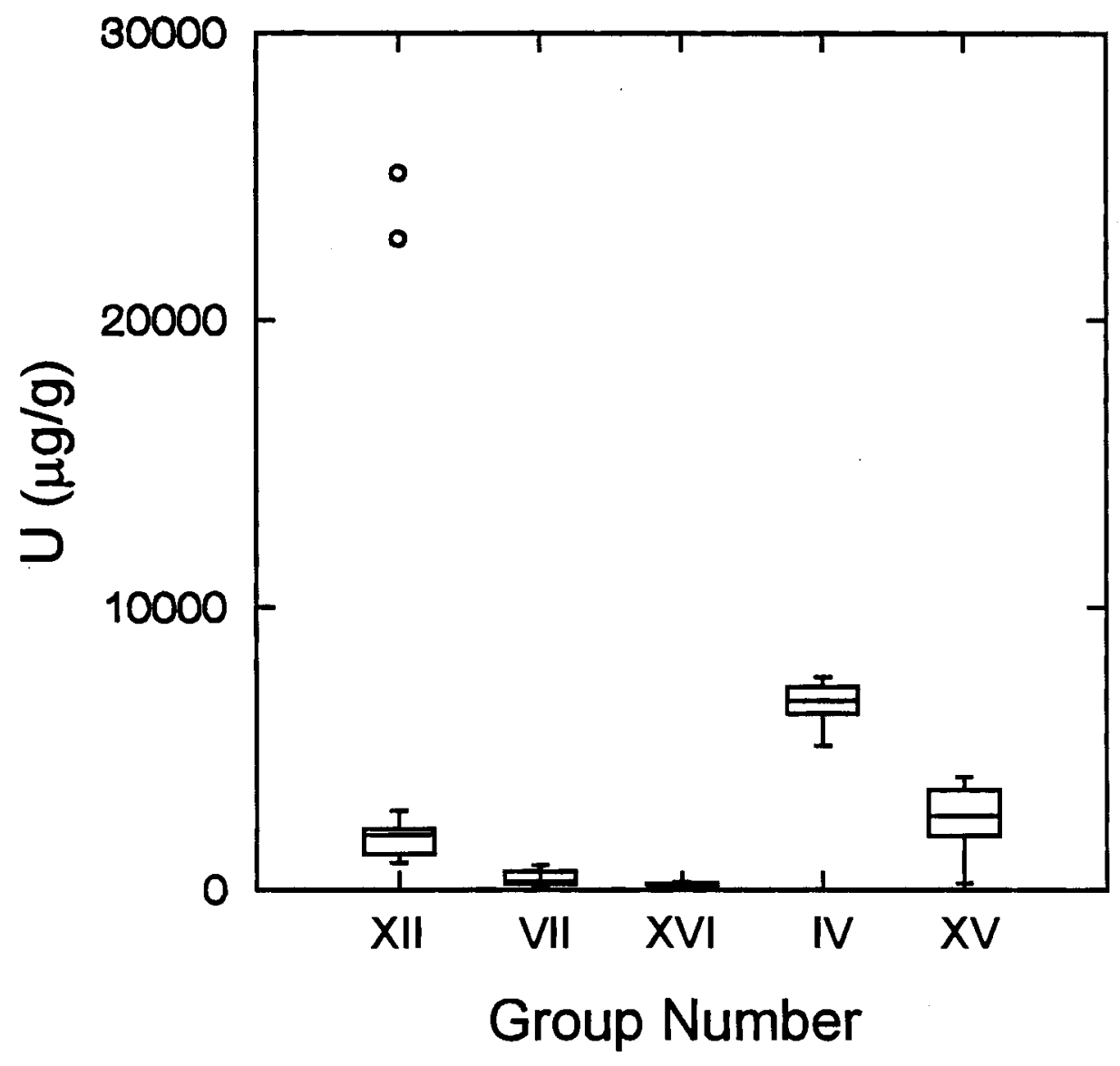

D. 14 


\section{Box Plot of PO4 Concentrations in SORWT Groups}

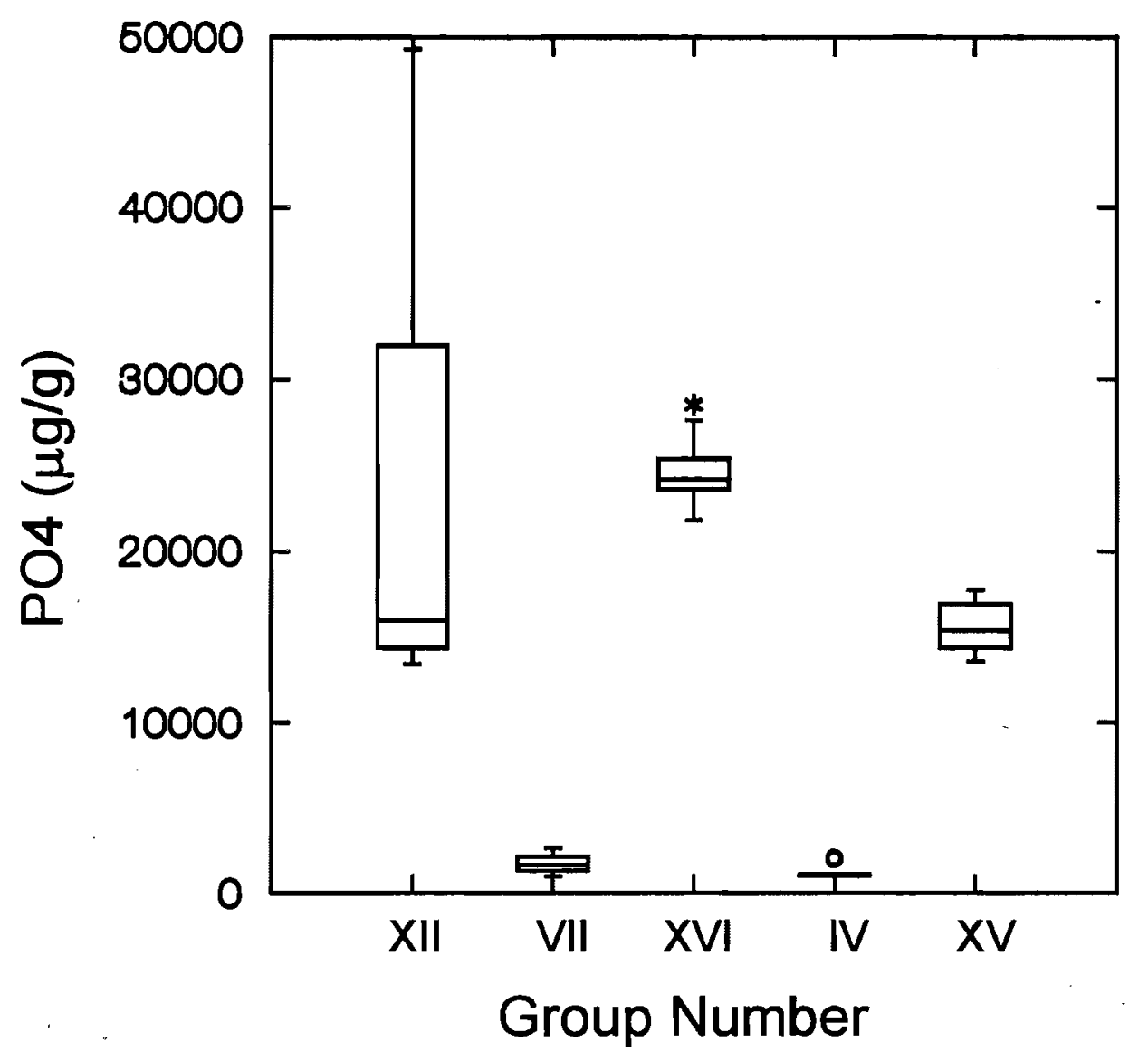


Box Plot of NO3 Concentrations in SORWT Groups

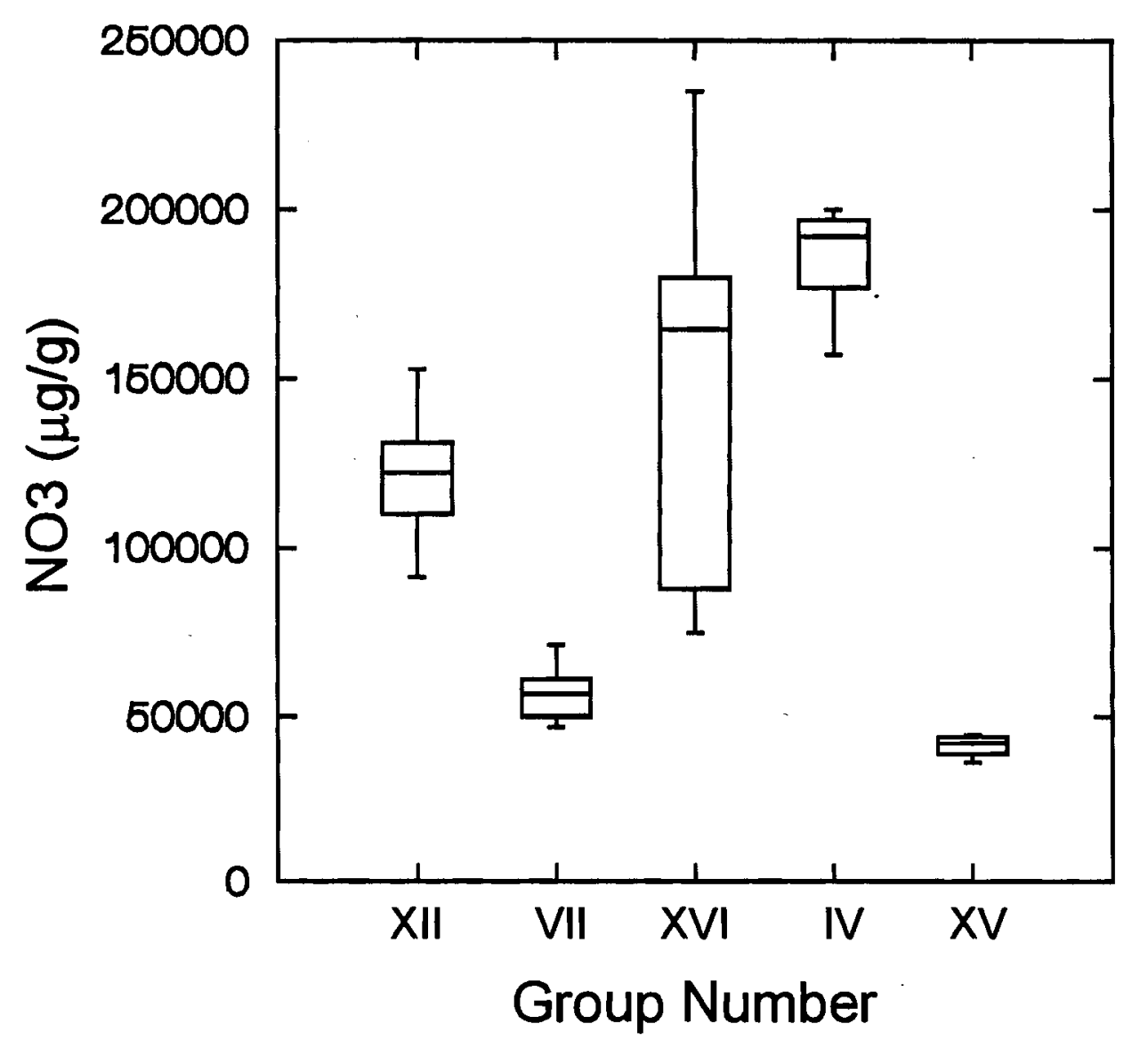




\section{Box Plot of NO2 Concentrations in SORWT Groups}

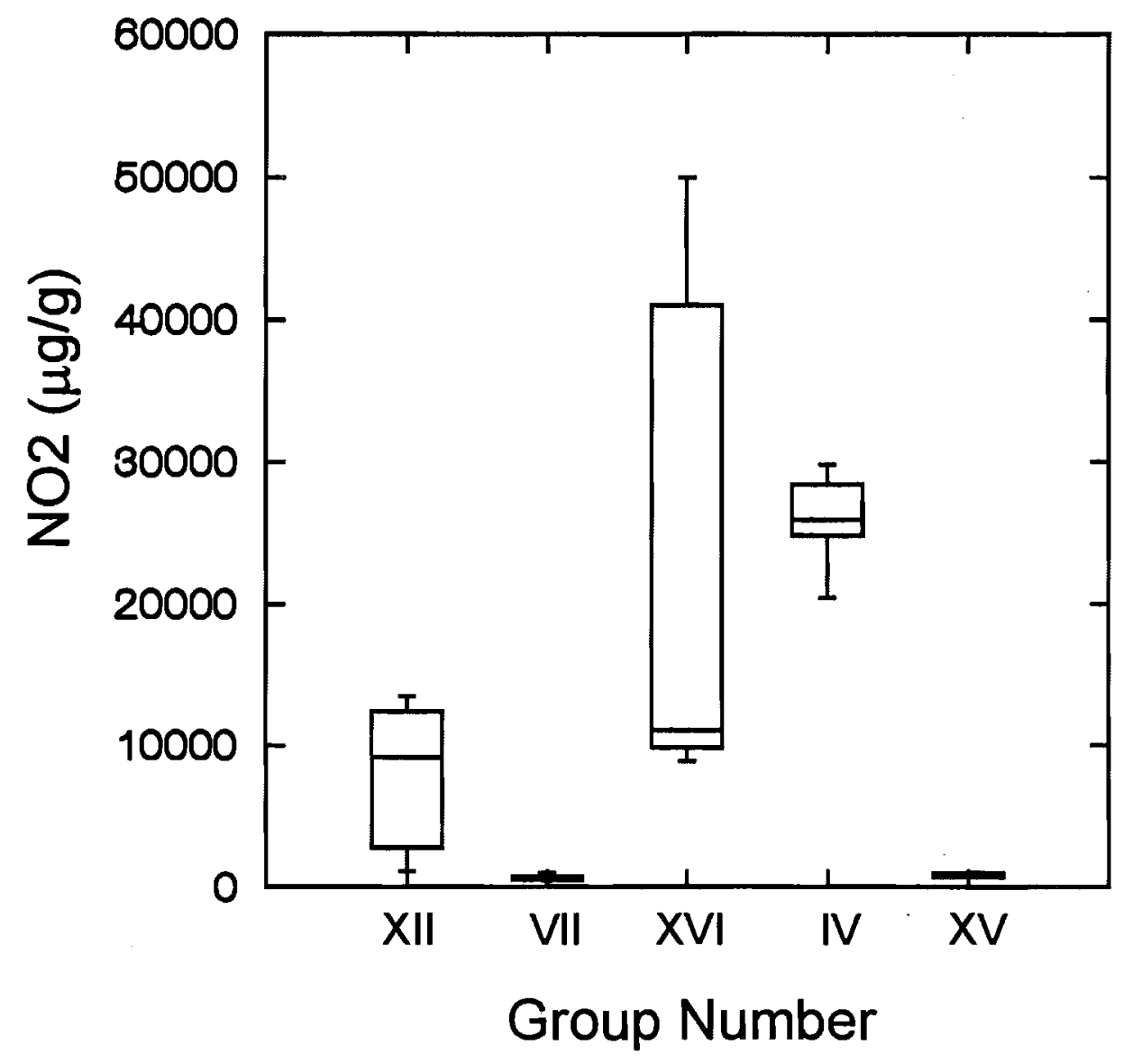


Box Plot of F Concentrations in SORWT Groups

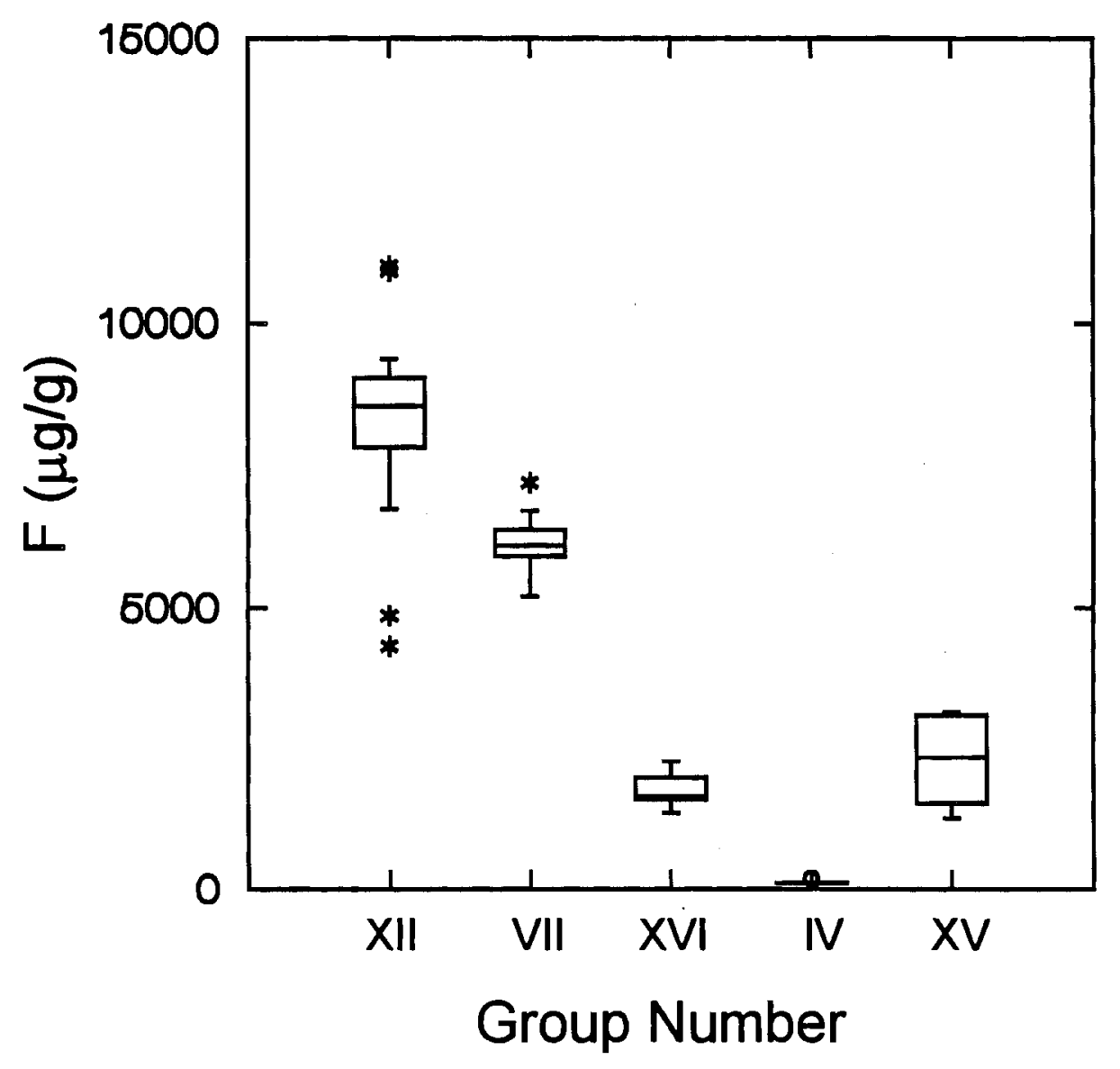

D. 18

PNL-9814 Rev 2 


\section{Box Plot of Cl Concentrations in SORWT Groups}

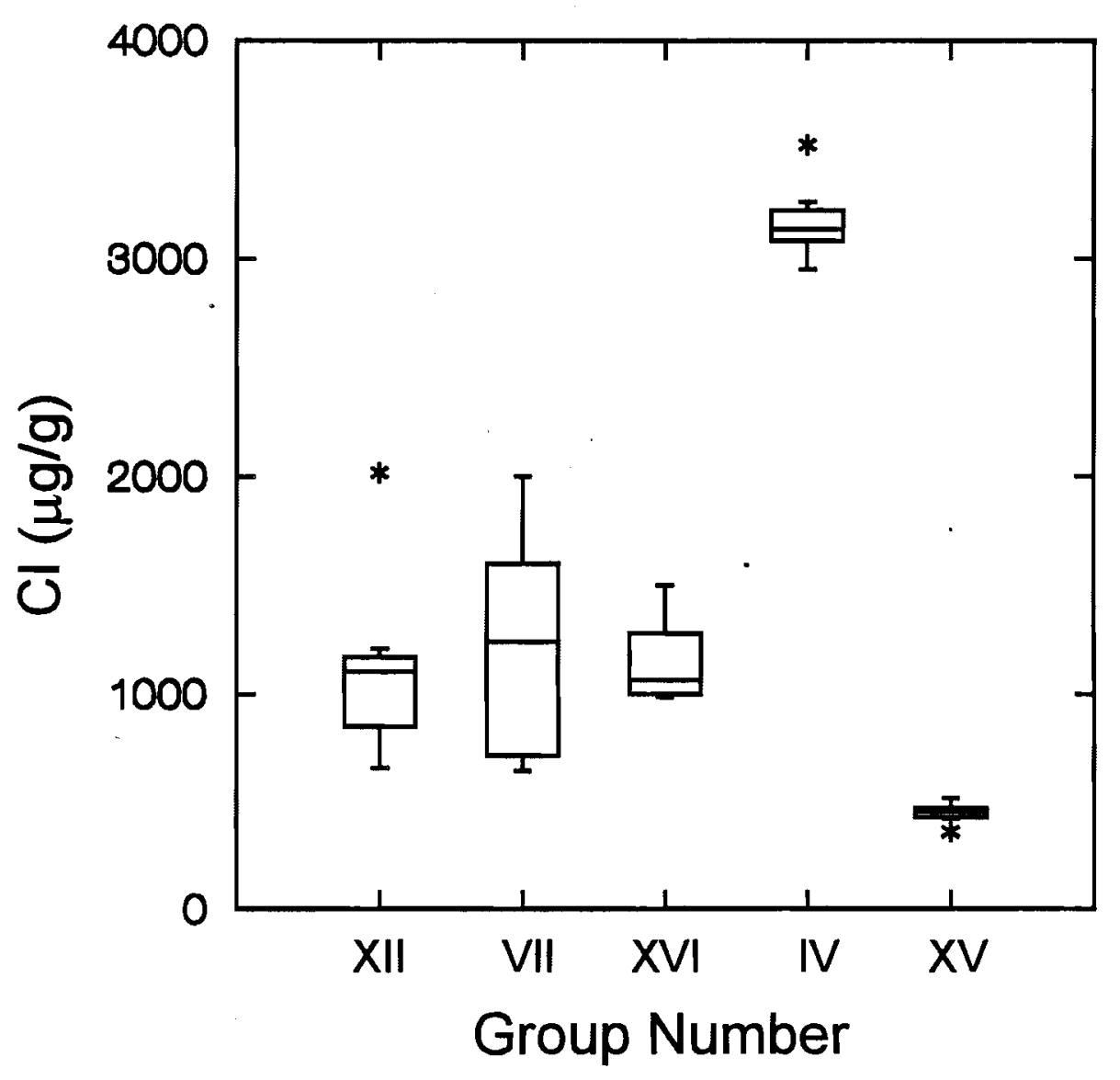

D. 19 


\section{Box Plot of TOC Concentrations in SORWT Groups}

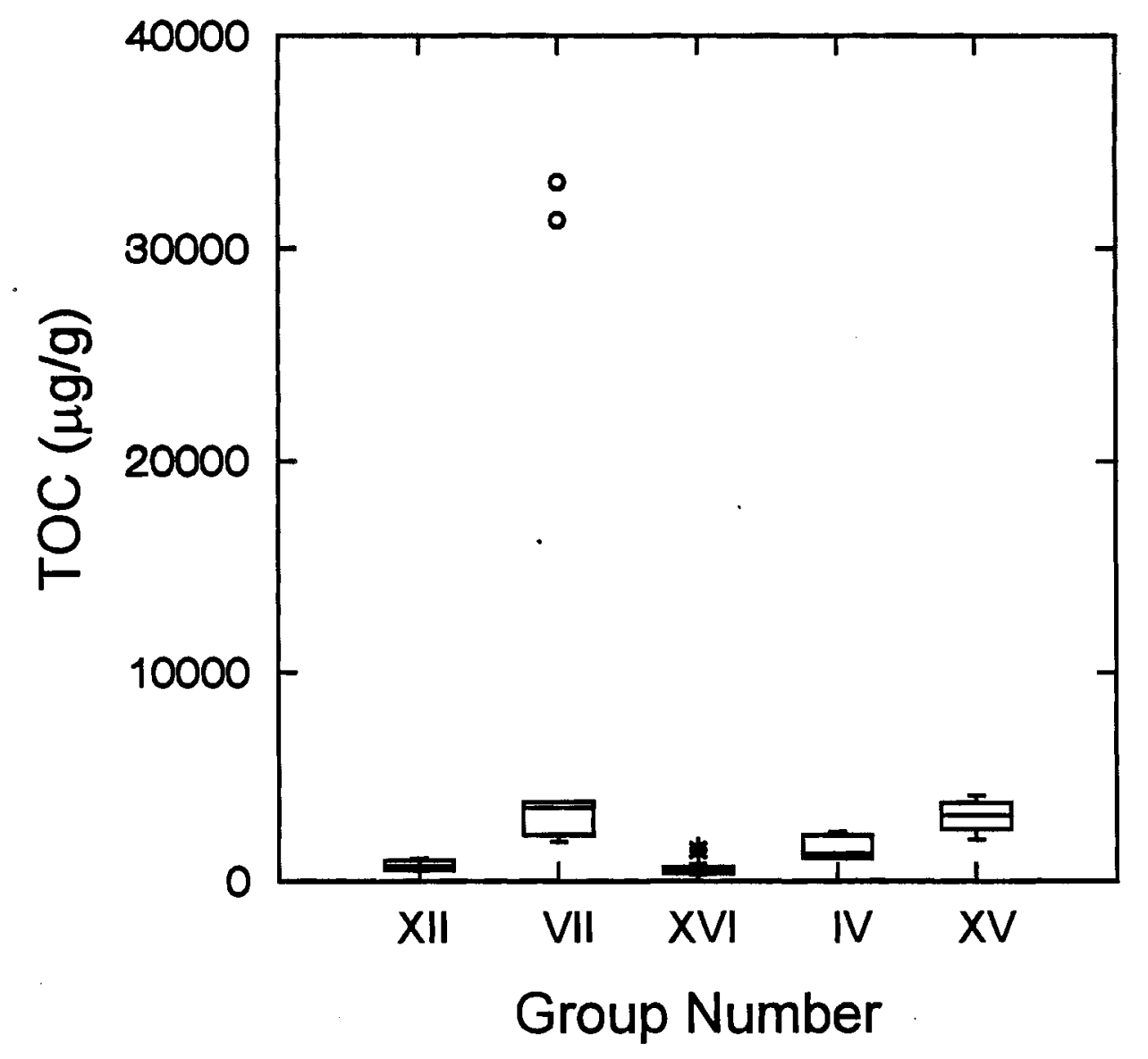




\section{Appendix E}

\section{ANOVA Results of Core Sample Analytical Data Used in the SORWT Model Verification Study}



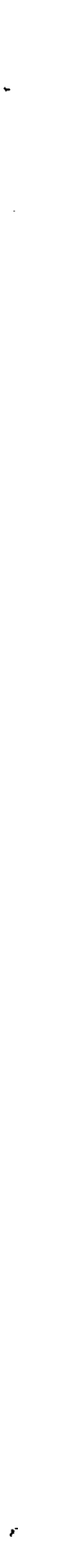

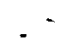


FRI $1 / 27 / 95 \quad 1: 24: 29$ PM D: ISORWTISORWTDAT.SYS LEVELS ENCOUNTERED DURING PROCESSING ARE: GROUPNO\$

IV VII $\quad$ XII $\quad$ XV $\quad$ XVI

5 CASES DELETED DUE TO MISSING DATA.

DEP VAR: $\quad$ AL $\quad \mathrm{N}: \quad 103$ MULTIPLE R: 0.998 SQUARED MULTIPLE R: 0.996

ANALYSIS OF VARIANCE

$\begin{array}{lccccc}\text { SOURCE } & \text { SUM-OF-SQUARES } & \text { DF } & \text { MEAN-SQUARE } & \text { F-RATIO } & \text { P } \\ \text { GROUPNO } & .137018 E+12 & 4 & .342544 E+11 & 5514.853 & 0.000 \\ \text { ERROR } & .608707 E+09 & 98 & 6211300.211 & & \end{array}$

FRI $1 / 27 / 95 \quad 1: 24: 55$ PM D: ISORWTISORWTDAT.SYS

COL/

ROW GROUPNO\$

1 IV

2 VII

$3 X I I$

$4 \quad X V$

$5 X V I$

USING LEAST SQUARES MEANS.

POST HOC TEST OF AL

USING MODEL MSE OF 6211300.211 WITH 98. DF.

MATRIX OF .PAIRWISE MEAN DIFFERENCES:

\begin{tabular}{rrrrrr} 
& 1 & 2 & 3 & 4 & \multicolumn{1}{l}{5} \\
1 & 0.000 & & & & \\
2 & -113510.000 & 0.000 & & & \\
3 & -102677.434 & 10832.566 & 0.000 & & \\
4 & -116430.000 & -2920.000 & -13752.566 & 0.000 & \\
5 & -115575.229 & -2065.229 & -12897.795 & 854.771 & 0.000
\end{tabular}

TUKEY HSD MULTIPLE COMPARISONS.

MATRIX OF PAIRWISE COMPARISON PROBABILITIES:

$\begin{array}{llllll} & 1 & 2 & 3 & 4 & 5 \\ 1 & 1.000 & & & & \\ 2 & 0.000 & 1.000 & & & \\ 3 & 0.000 & 0.000 & 1.000 & & \\ 4 & 0.000 & 0.056 & 0.000 & 1.000 & \\ 5 & 0.000 & 0.033 & 0.000 & 0.897 & 1.000\end{array}$


FRI $1 / 27 / 95 \quad 1: 26: 32$ PM D: ISORWTISORWTDAT.SYS LEVELS ENCOUNTERED DURING PROCESSING ARE:

GROUPNOS

$\begin{array}{lllll}\text { IV } & \text { VII } & \text { XII } & \text { XV }\end{array}$

5 CASES DELETED DUE TO MISSING DATA.

DEP VAR: $\quad B I \quad N: \quad 103$ MULTIPLE R: 0.805 SQUARED MULTIPLE R: 0.648

\begin{tabular}{lccccc}
\multicolumn{5}{c}{ ANALYSIS } & OF VARIANCE \\
SOURCE & SUM-OF-SQUARES & DF & MEAN-SQUARE & F-RATIO & P \\
GROUPNOS & $.329519 E+11$ & 4 & $.823799 E+10$ & 45.153 & 0.000 \\
ERROR & $.178796 E+11$ & 98 & $.182445 E+09$ & &
\end{tabular}

FRI $1 / 27 / 95 \quad 1: 26: 41$ PM D: ISORWTISORWTDAT.SYS

COL/

ROW GROUPNOS

1 IV

2 VII

$3 X I I$

$4 \mathrm{XV}$

$5 X V I$

USING LEAST SQUARES MEANS.

POST HOC TEST OF BI

USING MODEL MSE OF ******** WITH 98. DF.

MATRIX OF PAIRWISE MEAN DIFFERENCES:

\begin{tabular}{rrrrrr} 
& \multicolumn{1}{c}{1} & \multicolumn{1}{c}{2} & \multicolumn{1}{c}{3} & \multicolumn{1}{c}{4} & \multicolumn{1}{c}{5} \\
\hline 1 & 0.000 & & & & \\
2 & 61714.696 & 0.000 & & & \\
3 & 17316.781 & -44397.915 & 0.000 & & \\
4 & 23523.725 & -38190.971 & 6206.944 & 0.000 & \\
5 & 19315.017 & -42399.679 & 1998.236 & -4208.708 & 0.000
\end{tabular}

TUKEY HSD MULTIPLE COMPARISONS.

MATRIX OF PAIRWISE COMPARISON PROBABILITIES:

$\begin{array}{llllll} & 1 & 2 & 3 & 4 & 5 \\ 1 & 1.000 & & & & \\ 2 & 0.000 & 1.000 & & & \\ 3 & 0.008 & 0.000 & 1.000 & & \\ 4 & 0.002 & 0.000 & 0.816 & 1.000 & \\ 5 & 0.000 & 0.000 & 0.984 & 0.925 & 1.000\end{array}$


FRI $1 / 27 / 95 \quad 1: 28: 10$ PM D: ISORWTISORWTDAT.SYS

LEVELS ENCOUNTERED DURING PROCESSING ARE:

GROUPNO\$

$\begin{array}{lllll}\text { IV } & \text { VII } & \text { XII } & \text { XV }\end{array}$

5 CASES DELETED DUE TO MISSING DATA.

DEP VAR: $\quad$ CR $\quad \mathrm{N}: \quad 103$ MULTIPLE R: 0.944 SQUARED MULTIPLE R: 0.891

ANALYSIS OF VARIANCE

$\begin{array}{lcrccc}\text { SOURCE } & \text { SUM-OF-SQUARES } & \text { DF } & \text { MEAN-SQUARE } & \text { F-RATIO } & P \\ \text { GROUPNO } & .707020 E+08 & 4 & .176755 E+08 & 199.780 & 0.000 \\ \text { ERROR } & 8670526.646 & 98 & 88474.762 & & \\ & & & & & \\ \text { FRI } & 1 / 27 / 95 & 1: 28: 16 \text { PM } & \text { D: ISORWTISORWTDAT.SYS } & \\ \text { COL/ } & & & & \\ \text { ROW GROUPNO } & & & & \\ 1 & \text { IV } & & & \\ 2 & \text { VII } & & & & \\ 3 & \text { XII } & & & & \\ 4 & \text { XV } & & & & \\ 5 & \text { XVI }\end{array}$

USING LEAST SQUARES MEANS.

POST HOC TEST OF $\quad$ CR

USING MODEL MSE OF 88474.762 WITH 98. DF.

MATRIX OF PAIRWISE MEAN DIFFERENCES:

\begin{tabular}{rrrrrr} 
& \multicolumn{1}{c}{1} & 2 & 3 & 4 & \multicolumn{1}{c}{5} \\
1 & 0.000 & & & & \\
2 & 481.667 & 0.000 & & & \\
3 & -1668.333 & -2150.000 & 0.000 & & \\
4 & -554.583 & -1036.250 & 1113.750 & 0.000 & \\
5 & -1499.438 & -1981.104 & 168.896 & -944.854 & 0.000
\end{tabular}

TUKEY HSD MULTIPLE COMPARISONS.

MATRIX OF PAIRWISE COMPARISON PROBABILITIES:

$\begin{array}{llllll} & 1 & 2 & 3 & 4 & 5 \\ 1 & 1.000 & & & & \\ 2 & 0.000 & 1.000 & & & \\ 3 & 0.000 & 0.000 & 1.000 & & \\ 4 & 0.001 & 0.000 & 0.000 & 1.000 & \\ 5 & 0.000 & 0.000 & 0.248 & 0.000 & 1.000\end{array}$


FRI 1/27/95 1:28:43 PM D: ISORWTISORWTDAT.SYS

LEVELS ENCOUNTERED DURING PROCESSING ARE: GROUPNO\$

IV

5 CASES DELETED DUE TO MISSING DATA.

DEP VAR: $\quad$ FE $\quad \mathrm{N}: \quad 103$ MULTIPLE R: 0.869 SQUARED MULTIPLE R: 0.755

ANALYSIS OF VARIANCE

$\begin{array}{lccccc}\text { SOURCE } & \text { SUM-OF-SQUARES } & \text { DF } & \text { MEAN-SQUARE } & \text { F-RATIO } & P \\ \text { GROUPNOS } & .299271 E+10 & 4 & .748177 E+09 & 75.346 & 0.000 \\ \text { ERROR } & .973134 E+09 & 98 & 9929936.716 & & \end{array}$

FRI 1/27/95 1:29:00 PM D: ISORWTISORWTDAT.SYS

COL/

ROW GROUPNO\$

1 IV

2 VII

3 XII

4 XV

$5 X V I$

USING LEAST SQUARES MEANS.

POST HOC TEST OF FE

USING MODEL MSE OF 9929936.716 WITH 98. DF. MATRIX OF PAIRWISE MEAN DIFFERENCES:

\begin{tabular}{rrrrrr} 
& 1 & 2 & 3 & \multicolumn{1}{c}{4} & \multicolumn{1}{c}{5} \\
1 & 0.000 & & & & \\
2 & 8731.872 & 0.000 & & & \\
3 & 9387.892 & 656.020 & 0.000 & & \\
4 & 16613.725 & 7881.853 & 7225.833 & 0.000 & \\
5 & 16062.329 & 7330.457 & 6674,438 & -551.396 & 0.000
\end{tabular}

TUKEY HSD MULTIPLE COMPARISONS.

MATRIX OF PAIRWISE COMPARISON PROBABILITIES:

$\begin{array}{llllll} & 1 & 2 & 3 & 4 & 5 \\ 1 & 1.000 & & & & \\ 2 & 0.000 & 1.000 & & & \\ 3 & 0.000 & 0.972 & 1.000 & & \\ 4 & 0.000 & 0.000 & 0.000 & 1.000 & 1.000 \\ 5 & 0.000 & 0.000 & 0.000 & 0.991 & 1.000\end{array}$


FRI 1/27/95 1:29:25 PM D: ISORWT ISORWTDAT.SYS LEVELS ENCOUNTERED DURING PROCESSING ARE: GROUPNO\$

IV VII $\quad$ XII $\quad$ XV

5 CASES DELETED DUE TO MISSING DATA.

DEP VAR: LA $\quad \mathrm{N}: \quad 103$ MULTIPLE R: 0.995 SQUARED MULTIPLE R: 0.989

ANALYSIS OF VARIANCE

$\begin{array}{lccccc}\text { SOURCE } & \text { SUM-OF-SQUARES } & \text { DF } & \text { MEAN-SQUARE } & \text { F-RATIO } & \text { P } \\ \text { GROUPNO } & .257985 E+10 & 4 & .644963 E+09 & 2284.408 & 0.000 \\ \text { ERROR } & .276686 E+08 & 98 & 282332.659 & & \end{array}$

FRI 1/27/95 1:29:38 PM D: ISORWTISORWTDAT.SYS

$\mathrm{COL} /$

ROW GROUPNO\$

1 IV

2 VII

$3 \mathrm{XII}$

$4 \quad X V$

$5 X V I$

USING LEAST SQUARES MEANS.

POST HOC TEST OF LA

USING MODEL MSE OF 282332.659 WITH 98. DF.

MATRIX OF PAIRWISE MEAN DIFFERENCES:

(1)

\begin{tabular}{rrrrrr} 
& \multicolumn{1}{c}{1} & 2 & 3 & 4 & \multicolumn{1}{c}{5} \\
1 & 0.000 & & & & \\
2 & 13582.117 & 0.000 & & & \\
3 & -1.445 & -13583.562 & 0.000 & & \\
4 & 4098.087 & -9484.029 & 4099.533 & 0.000 & \\
5 & 64.190 & -13517.927 & 65.635 & -4033.898 & 0.000
\end{tabular}

TUKEY HSD MULTIPLE COMPARISONS.

MATRIX OF PAIRWISE COMPARISON PROBABILITIES:

$\begin{array}{llllll} & 1 & 2 & 3 & 4 & 5 \\ 1 & 1.000 & & & & \\ 2 & 0.000 & 1.000 & & & \\ 3 & 1.000 & 0.000 & 1.000 & & \\ 4 & 0.000 & 0.000 & 0.000 & 1.000 & \\ 5 & 0.996 & 0.000 & 0.992 & 0.000 & 1.000\end{array}$


FRI $1 / 27 / 95 \quad 1: 29: 54$ PM D: ISORWTISORWTDAT.SYS

LEVELS ENCOUNTERED DURING PROCESSING ARE:

GROUPNOS

IV

VII

XII

$X V$

XVI

5 CASES DELETED DUE TO MISSING DATA.

DEP VAR: MN $\quad \mathrm{N}: \quad 103$ MULTIPLE R: 0.852 SQUARED MULTIPLE R: 0.725

ANALYSIS OF VARIANCE

$\begin{array}{lccccc}\text { SOURCE } & \text { SUM-OF-SQUARES } & \text { DF } & \text { MEAN-SQUARE } & \text { F-RATIO } & \text { P } \\ \text { GROUPNOS } & .293853 E+10 & 4 & .734633 E+09 & 64.674 & 0.000 \\ \text { ERROR } & .111318 E+10 & 98 & .113590 E+08 & & \end{array}$

FRI 1/27/95 1:30:05 PM D: ISORWTISORWTDAT.SYS

COL/

ROW GROUPNOS

$\begin{array}{ll}1 & \text { IV } \\ 2 & V I I \\ 3 & X I I \\ 4 & X V \\ 5 & X V I\end{array}$

USING LEAST SQUARES MEANS.

POST HOC TEST OF MN

USING MODEL MSE OF 11359012.943 WITH 98. DF.

MATRIX OF PAIRWISE MEAN DIFFERENCES:

\begin{tabular}{rrrrrr} 
& \multicolumn{1}{c}{1} & 2 & 3 & 4 & \multicolumn{1}{c}{5} \\
1 & 0.000 & & & & \\
2 & 13358.387 & 0.000 & & & \\
3 & -1091.972 & -14450.359 & 0.000 & & \\
4 & 5132.417 & -8225.971 & 6224.389 & 0.000 & \\
5 & -1052.854 & -14411.241 & 39.118 & -6185.271 & 0.000
\end{tabular}

TUKEY HSD MULTIPLE COMPARISONS.

MATRIX OF PAIRWISE COMPARISON PROBABILITIES:

$\begin{array}{llllll} & 1 & 2 & 3 & 4 & 5 \\ 1 & 1.000 & & & & \\ 2 & 0.000 & 1.000 & & & \\ 3 & 0.907 & 0.000 & 1.000 & & \\ 4 & 0.010 & 0.000 & 0.000 & 1.000 & \\ 5 & 0.869 & 0.000 & 1.000 & 0.000 & 1.000\end{array}$


FRI 1/27/95 1:33:56 PM D: ISORWTISORWTDAT.SYS

LEVELS ENCOUNTERED DURING PROCESSING ARE:

GROUPNO\$

IV

VII XII XV

XVI

5 CASES DELETED DUE TO MISSING DATA.

DEP VAR: NA $\quad \mathrm{N}: \quad 103$ MULTIPLE R: 0.970 SQUARED MULTIPLE R: 0.940

ANALYSIS OF VARIANCE

$\begin{array}{lccccc}\text { SOURCE } & \text { SUM-OF-SQUARES } & \text { DF } & \text { MEAN-SQUARE } & \text { F-RATIO } & \text { P } \\ \text { GROUPNO } & .709272 E+11 & 4 & .177318 E+11 & 385.204 & 0.000 \\ \text { ERROR } & .451116 E+10 & 98 & .460323 E+08 & & \end{array}$

FRI $1 / 27 / 95 \quad 1: 34: 29$ PM D: ISORWTISORWTDAT.SYS

COL/

ROW GROUPNO\$

$\begin{array}{ll}1 & \text { IV } \\ 2 & \text { VII } \\ 3 & X I I \\ 4 & X V \\ 5 & X V I\end{array}$

USING LEAST SQUARES MEANS.

POST HOC TEST OF NA

USING MODEL MSE OF 46032257.982 WITH 98. DF.

MATRIX OF PAIRWISE MEAN DIFFERENCES:

$\begin{array}{rrrrrr} & 1 & 2 & 3 & 4 & 5 \\ 1 & 0.000 & & & & \\ 2 & .76885 .941 & 0.000 & & & \\ 3 & -27116.667 & 49769.275 & 0.000 & & \\ 4 & .81300 .000 & -4414.059 & -54183.333 & 0.000 & \\ 5 & .21891 .188 & 54994.754 & 5225.479 & 59408.813 & 0.000\end{array}$

TUKEY HSD MULTIPLE COMPARISONS

MATRIX OF PAIRWISE COMPARISON PROBABILITIES:

$\begin{array}{llllll} & 1 & 2 & 3 & 4 & 5 \\ 1 & 1.000 & & & & \\ 2 & 0.000 & 1.000 & & & \\ 3 & 0.000 & 0.000 & 1.000 & & \\ 4 & 0.000 & 0.554 & 0.000 & 1.000 & \\ 5 & 0.000 & 0.000 & 0.049 & 0.000 & 1.000\end{array}$


FRI $1 / 27 / 95 \quad 1: 34: 47$ PM D: ISORWTISORWTDAT.SYS

LEVELS ENCOUNTERED DURING PROCESSING ARE:

GROUPNOS

IV

$$
\text { VII XII XV XVI }
$$

5 CASES DELETED DUE TO MISSING DATA.

DEP VAR: $\quad$ PB $\quad \mathrm{N}: \quad 103$ MULTIPLE R: 0.618 SQUARED MULTIPLE R: 0.381

ANALYSIS OF VARIANCE

$\begin{array}{lccccc}\text { SOURCE } & \text { SUM-OF-SQUARES } & \text { DF } & \text { MEAN-SQUARE } & \text { F-RATIO } & \text { P } \\ \text { GROUPNOS } & .131325 E+08 & 4 & 3283114.895 & 15.108 & 0.000 \\ \text { ERROR } & .212966 E+08 & 98 & 217312.653 & & \end{array}$

FRI 1/27/95 1:34:55 PM D: ISORWTISORWTDAT.SYS

COL/

ROW GROUPNOS

$\begin{array}{ll}1 & \text { IV } \\ 2 & V I I \\ 3 & X I I \\ 4 & X V \\ 5 & X V I\end{array}$

USING LEAST SQUARES MEANS.

POST HOC TEST OF PB

USING MODEL MSE OF 217312.653 WITH 98. DF.

MATRIX OF PAIRWISE MEAN DIFFERENCES:

\begin{tabular}{rrrrrr} 
& \multicolumn{1}{c}{1} & 2 & \multicolumn{1}{c}{3} & \multicolumn{1}{c}{4} & \multicolumn{1}{c}{5} \\
1 & 0.000 & & & & \\
2 & 1085.904 & 0.000 & & & \\
3 & 142.831 & -943.074 & 0.000 & & \\
4 & 326.500 & -759.404 & 183.669 & 0.000 & \\
5 & 711.304 & -374.600 & 568.474 & 384.804 & 0.000
\end{tabular}

TUKEY HSD MULTIPLE COMPARISONS.

MATRIX OF PAIRWISE COMPARISON PROBABILITIES:

$\begin{array}{llllll} & 1 & 2 & 3 & 4 & 5 \\ 1 & 1.000 & & & & \\ 2 & 0.000 & 1.000 & & & \\ 3 & 0.923 & 0.000 & 1.000 & & \\ 4 & 0.543 & 0.002 & 0.886 & 1.000 . & \\ 5 & 0.000 & 0.042 & 0.000 & 0.203 & 1.000\end{array}$


FRI $1 / 27 / 95 \quad 1: 40: 59$ PM D: ISORWTISORWTDAT.SYS

LEVELS ENCOUNTERED DURING PROCESSING ARE:

GROUPNO\$

IV

VII XII XV

XV XVI

5 CASES DELETED DUE TO MISSING DATA.

DEP VAR: $\quad$ SI $\quad \mathrm{N}: \quad 103$ MULTIPLE R: 0.431 SQUARED MULTIPLE R: 0.186

ANALYSIS OF VARIANCE

$\begin{array}{lccccc}\text { SOURCE } & \text { SUM-OF-SQUARES } & \text { DF } & \text { MEAN-SQUARE } & \text { F-RATIO } & \text { P } \\ \text { GROUPNOS } & .169385 E+10 & 4 & .423462 E+09 & 5.581 & 0.000 \\ \text { ERROR } & .743582 E+10 & 98 & .758757 E+08 & & \end{array}$

FRI 1/27/95 1:41:06 PM D: ISORWTISORWTDAT.SYS

$\mathrm{COL} /$

ROW GROUPNOS

$\begin{array}{ll}1 & \text { IV } \\ 2 & V I I \\ 3 & X I I \\ 4 & X V \\ 5 & X V I\end{array}$

USING LEAST SQUARES MEANS.

POST HOC TEST OF SI

USING MODEL MSE OF 75875689.857 WITH 98. DF. MATRIX OF PAIRWISE MEAN DIFFERENCES:

\begin{tabular}{rrrrrr} 
& \multicolumn{1}{c}{1} & \multicolumn{1}{c}{2} & 3 & \multicolumn{1}{l}{4} & \multicolumn{1}{c}{5} \\
1 & 0.000 & & & & \\
2 & 14321.760 & 0.000 & & & \\
3 & 5606.361 & -8715.399 & 0.000 & & \\
4 & 4238.583 & -10083.176 & -1367.778 & 0.000 & \\
5 & 8846.979 & -5474.781 & 3240.618 & 4608.396 & 0.000
\end{tabular}

TUKEY HSD MULTIPLE COMPARISONS.

MATRIX OF PAIRWISE COMPARISON PROBABILITIES:

$\begin{array}{llllll} & 1 & 2 & 3 & 4 & 5 \\ 1 & 1.000 & & & & \\ 2 & 0.000 & 1.000 & & & \\ 3 & 0.422 & 0.031 & 1.000 & & \\ 4 & 0.823 & 0.061 & 0.996 & 1.000 & \\ 5 & 0.018 & 0.179 & 0.663 & 0.638 & 1.000\end{array}$


FRI 1/27/95 1:41:25 PM D: ISORWTISORWTDAT.SYS

LEVELS ENCOUNTERED DURING PROCESSING ARE:

GROUPNO\$

IV VII XII XV XVI

5 CASES DELETED DUE TO MISSING DATA.

DEP VAR: $\quad$ ZR $\quad \mathrm{N}: \quad 103$ MULTIPLE R: 0.365 SQUARED MULTIPLE R: 0.133

ANALYSIS OF VARIANCE

$\begin{array}{lccccc}\text { SOURCE } & \text { SUM-OF-SQUARES } & \text { DF } & \text { MEAN-SQUARE } & \text { F-RATIO } & P \\ \text { GROUPNOS } & 338155.908 & 4 & 84538.977 & 3.764 & 0.007 \\ \text { ERROR } & 2201118.624 & 98 & 22460.394 & & \end{array}$

FRI $1 / 27 / 95 \quad 1: 41: 33$ PM D: ISORWTISORWTDAT.SYS

COL/

ROW GROUPNOS

1 IV

2 VII

$3 X I I$

$4 \mathrm{XV}$

$5 X V I$

USING LEAST SQUARES MEANS.

POST HOC TEST OF ZR

USING MODEL MSE OF 22460.394 WITH 98. DF. MATRIX OF PAIRWISE MEAN DIFFERENCES:

\begin{tabular}{rrrrrr} 
& \multicolumn{1}{c}{1} & \multicolumn{1}{c}{2} & \multicolumn{1}{c}{3} & \multicolumn{1}{l}{4} & \multicolumn{1}{l}{5} \\
1 & 0.000 & & & & \\
2 & 7.705 & 0.000 & & & \\
3 & 131.771 & 124.066 & 0.000 & & \\
4 & -17.210 & -24.916 & -148.982 & 0.000 & \\
5 & 112.542 & 104.837 & -19.229 & 129.752 & 0.000
\end{tabular}

TUKEY HSD MULTIPLE COMPARISONS.

MATRIX OF PAIRWISE COMPARISON PROBABILITIES:

$\begin{array}{llllll} & 1 & 2 & 3 & 4 & 5 \\ 1 & 1.000 & & & & \\ 2 & 1.000 & 1.000 & & & \\ 3 & 0.136 & 0.112 & 1.000 & & \\ 4 & 0.999 & 0.995 & 0.141 & 1.000 & \\ 5 & 0.145 & 0.104 & 0.990 & 0.165 & 1.000\end{array}$


FRI $1 / 27 / 95 \quad 1: 41: 51$ PM D: ISORWTISORWTDAT.SYS

LEVELS ENCOUNTERED DURING PROCESSING ARE: GROUPNO\$

IV

VII XII XV

$X V I$

8 CASES DELETED DUE TO MISSING DATA.

DEP VAR: $\operatorname{CS} 137 \quad \mathrm{~N}: \quad 100$ MULTIPLE R: 0.486 SQUARED MULTIPLE R: 0.236

ANALYSIS OF VARIANCE

$\begin{array}{lrrccc}\text { SOURCE } & \text { SUM-OF-SQUARES } & \text { DF } & \text { MEAN-SQUARE } & \text { F-RATIO } & \text { P } \\ \text { GROUPNOS } & 42611.220 & 4 & 10652.805 & 7.339 & 0.000 \\ \text { ERROR } & 137887.504 & 95 & 1451.447 & & \end{array}$

FRI $1 / 27 / 95 \quad 1: 41: 59$ PM D:ISORWTISORWTDAT.SYS

COL/

ROW GROUPNO\$

1 IV

2 VII

3 XII

4 XV

$5 X V I$

USING LEAST SQUARES MEANS.

POST HOC TEST OF $\quad$ CS137

USING MODEL MSE OF 1451.447 WITH 95. DF. MATRIX OF PAIRWISE MEAN DIFFERENCES:

\begin{tabular}{rrrrrl} 
& 1 & 2 & 3 & 4 & \multicolumn{1}{l}{5} \\
1 & 0.000 & & & & \\
2 & -61.905 & 0.000 & & & \\
3 & -43.775 & 18.130 & 0.000 & & \\
4 & -62.142 & -0.237 & -18.367 & 0.000 & \\
5 & .21 .670 & 40.235 & 22.105 & 40.472 & 0.000
\end{tabular}

TUKEY HSD MULTIPLE COMPARISONS.

MATRIX OF PAIRWISE COMPARISON PROBABILITIES:

$\begin{array}{llllll} & 1 & 2 & 3 & 4 & 5 \\ 1 & 1.000 & & & & \\ 2 & 0.000 & 1.000 & & & \\ 3 & 0.022 & 0.612 & 1.000 & & \\ 4 & 0.005 & 1.000 & 0.788 & 1.000 & \\ 5 & 0.411 & 0.003 & 0.240 & 0.052 & 1.000\end{array}$


FRI 1/27/95 1:42:20 PM D: ISORWTISORWTDAT.SYS

LEVELS ENCOUNTERED DURING PROCESSING ARE:

GROUPNO\$

IV

VII $\quad$ XII

XVI

22 CASES DELETED DUE TO MISSING DATA.

DEP VAR: $\quad$ SR90 $\quad \mathrm{N}: \quad 86$ MULTIPLE R: 0.872 SQUARED MULTIPLE R: 0.761

ANALYSIS OF VARIANCE

$\begin{array}{lccccc}\text { SOURCE } & \text { SUM-OF-SQUARES } & \text { DF } & \text { MEAN-SQUARE } & \text { F-RATIO } & P \\ \text { GROUPNOS } & 951095.029 & 4 & 237773.757 & 64.538 & 0.000 \\ \text { ERROR } & 298426.030 & 81 & 3684.272 & & \end{array}$

FRI 1/27/95 1:42:32 PM D: ISORWT ISORWTDAT.SYS

COL/

ROW GROUPNO\$

1 IV

2 VII

$3 \mathrm{XII}$

4 XV

$5 X V I$

USING LEAST SQUARES MEANS.

POST HOC TEST OF $\quad$ SR9O

USING MODEL MSE OF 3684.272 WITH 81. DF. MATRIX OF PAIRWISE MEAN DIFFERENCES:

\begin{tabular}{rrrrrr} 
& \multicolumn{1}{c}{1} & \multicolumn{1}{c}{2} & \multicolumn{1}{c}{3} & \multicolumn{1}{c}{4} & \multicolumn{1}{c}{5} \\
1 & 0.000 & & & & \\
2 & -306.415 & 0.000 & & & \\
3 & -302.395 & 4.020 & 0.000 & & \\
4 & -304.170 & 2.245 & -1.775 & 0.000 & \\
5 & -176.147 & 130.268 & 126.248 & 128.023 & 0.000
\end{tabular}

TUKEY HSD MULTIPLE COMPARISONS.

MATRIX OF PAIRWISE COMPARISON PROBABILITIES:

$\begin{array}{llllll} & 1 & 2 & 3 & 4 & 5 \\ 1 & 1.000 & & & & \\ 2 & 0.000 & 1.000 & & & \\ 3 & 0.000 & 1.000 & 1.000 & & \\ 4 & 0.000 & 1.000 & 1.000 & 1.000 & \\ 5 & 0.000 & 0.000 & 0.000 & 0.000 & 1.000\end{array}$


FRI 1/27/95 1:43:01 PM D: ISORWTISORWTDAT.SYS

LEVELS ENCOUNTERED DURING PROCESSING ARE: GROUPNO\$

$\begin{array}{lllll}\text { IV } & \text { VII } & \text { XII } & \text { XV }\end{array}$

22 CASES DELETED DUE TO MISSING DATA.

DEP VAR: PU23940 N: $\quad 86$ MULTIPLE R: 0.638 SQUARED MULTIPLE R: 0.407

ANALYSIS OF VARIANCE

$\begin{array}{lccccc}\text { SOURCE } & \text { SUM-OF-SQUARES } & \text { DF } & \text { MEAN-SQUARE } & \text { F-RATIO } & \text { P } \\ \text { GROUPNO\$ } & 3.558 & 4 & 0.890 & 13.915 & 0.000 \\ \text { ERROR } & 5.178 & 81 & 0.064 & & \end{array}$

FRI $1 / 27 / 95 \quad 1: 43: 07$ PM D: ISORWT ISORWTDAT.SYS

COL/

ROW GROUPNO\$

1 IV

2 VII

3 XII

$4 \mathrm{XV}$

$5 \mathrm{XVI}$

USING LEAST SQUARES MEANS.

POST HOC TEST OF PU23940

USING MODEL MSE OF $\quad .064$ WITH 81. DF. MATRIX OF PAIRWISE MEAN DIFFERENCES:

$\begin{array}{llllll} & 1 & 2 & 3 & 4 & 5 \\ 1 & 0.000 & & & & \\ 2 & 0.324 & 0.000 & & & \\ 3 & -0.212 & -0.536 & 0.000 & & \\ 4 & -0.143 & -0.467 & 0.069 & 0.000 & \\ 5 & -0.175 & -0.499 & 0.037 & -0.032 & 0.000\end{array}$

TUKEY HSD MULTIPLE COMPARISONS.

MATRIX OF PAIRWISE COMPARISON PROBABILITIES:

$\begin{array}{llllll} & 1 & 2 & 3 & 4 & 5 \\ 1 & 1.000 & & & & \\ 2 & 0.008 & 1.000 & . & & \\ 3 & 0.172 & 0.000 & 1.000 & & \\ 4 & 0.727 & 0.000 & 0.968 & 1.000 & \\ 5 & 0.263 & 0.000 & 0.988 & 0.998 & 1.000\end{array}$


FRI $1 / 27 / 95 \quad 1: 43: 35$ PM D: ISORWTISORWTDAT.SYS

LEVELS ENCOUNTERED DURING PROCESSING ARE:

GROUPNO\$

$\begin{array}{lllll}\text { IV } & \text { VII } & \text { XII } & \text { XV }\end{array}$

18 CASES DELETED DUE TO MISSING DATA.

DEP VAR: $\quad U \quad \mathrm{~N}: \quad 90$ MULTIPLE R: 0.600 SQUARED MULTIPLE R: 0.360

\begin{tabular}{lccccc}
\multicolumn{5}{c}{ ANALYSIS OF VARIANCE } \\
SOURCE & SUM-OF-SQUARES & DF & MEAN-SQUARE & F-RATIO & P \\
GROUPNO\$ & $.509678 E+09$ & 4 & $.127419 E+09$ & 11.945 & 0.000 \\
ERROR & $.906692 E+09$ & 85 & $.106670 E+08$ & &
\end{tabular}

FRI 1/27/95 1:43:41 PM D: ISORWTISORWTDAT.SYS

COL/

ROW GROUPNO\$

1 IV

2 VII

3 XII

4 XV

$5 X V I$

USING LEAST SQUARES MEANS.

POST HOC TEST OF $U$

USING MODEL MSE OF 10666968.923 WITH 85. DF.

MATRIX OF PAIRWISE MEAN DIFFERENCES:

\begin{tabular}{rrrrrr} 
& 1 & 2 & 3 & 4 & \multicolumn{1}{c}{5} \\
1 & 0.000 & & & & \\
2 & -6271.056 & .0 .000 & & & \\
3 & -2436.500 & 3834.556 & 0.000 & & \\
4 & -4130.000 & 2141.056 & -1693.500 & 0.000 & \\
5 & -6475.971 & -204.915 & -4039.471 & -2345.971 & 0.000
\end{tabular}

TUKEY HSD MULTIPLE COMPARISONS.

MATRIX OF PAIRWISE COMPARISON PROBABILITIES:

$\begin{array}{llllll} & 1 & 2 & 3 & 4 & 5 \\ 1 & 1.000 & & & & \\ 2 & 0.000 & 1.000 & & & \\ 3 & 0.274 & 0.006 & 1.000 & & \\ 4 & 0.052 & 0.538 & 0.740 & 1.000 & . \\ 5 & 0.000 & 1.000 & 0.001 & 0.365 & 1.000\end{array}$


FRI 1/27/95 1:44:02 PM D: ISORWTISORWTDAT.SYS LEVELS ENCOUNTERED DURING PROCESSING ARE: GROUPNO\$

$\begin{array}{lllll}\text { IV } & \text { VII } & \text { XII } & \text { XV }\end{array}$

32 CASES DELETED DUE TO MISSING DATA.

DEP VAR: PO4 N: $\quad 76$ MULTIPLE R: 0.878 SQUARED MULTIPLE R: 0.771

ANALYSIS OF VARIANCE

$\begin{array}{lccccc}\text { SOURCE } & \text { SUM-OF-SQUARES } & \text { DF } & \text { MEAN-SQUARE } & \text { F-RATIO } & \text { P } \\ \text { GROUPNO\$ } & .800097 E+10 & 4 & .200024 E+10 & 59.629 & 0.000 \\ \text { ERROR } & .238169 E+10 & 71 & .335449 E+08 & & \end{array}$

FRI 1/27/95 1:44:11 PM D:ISORWTISORWTDAT.SYS

COLI

ROW GROUPNO\$

$\begin{array}{ll}1 & \text { IV } \\ 2 & V I I \\ 3 & X I I \\ 4 & X V \\ 5 & X V I\end{array}$

USING LEAST SQUARES MEANS.

POST HOC TEST OF PO4

USING MODEL MSE OF 33544926.190 WITH 71. DF.

MATRIX OF PAIRWISE MEAN DIFFERENCES:

\begin{tabular}{rrrrrr} 
& \multicolumn{1}{c}{1} & 2 & 3 & 4 & \multicolumn{1}{c}{5} \\
1 & 0.000 & & & & \\
2 & 395.722 & 0.000 & & & \\
3 & 20945.556 & 20549.833 & 0.000 & & \\
4 & 14227.500 & 13831.778 & -6718.056 & 0.000 & \\
5 & 23244.545 & 22848.823 & 2298.990 & 9017.045 & 0.000
\end{tabular}

TUKEY HSD MULTIPLE COMPARISONS.

MATRIX OF PAIRWISE COMPARISON PROBABILITIES:

$\begin{array}{llllll} & 1 & 2 & 3 & 4 & 5 \\ 1 & 1.000 & & & & \\ 2 & 1.000 & 1.000 & & & \\ 3 & 0.000 & 0.000 & 1.000 & & \\ 4 & 0.000 & 0.000 & 0.060 & 1.000 & \\ 5 & 0.000 & 0.000 & 0.723 & 0.003 & 1.000\end{array}$


FRI 1/27/95 1:44:43 PM D: ISORWTISORWTDAT.SYS

LEVELS ENCOUNTERED DURING PROCESSING ARE:

GROUPNOS

IV VII $\quad$ XII $\quad X V \quad X V I$

32 CASES DELETED DUE TO MISSING DATA.

DEP VAR: N03 N: 76 MULTIPLE R: 0.853 SQUARED MULTIPLE R: 0.727

ANALYSIS OF VARIANCE

$\begin{array}{lccccc}\text { SOURCE } & \text { SUM-OF-SQUARES } & \text { DF } & \text { MEAN-SQUARE } & \text { F-RATIO } & \text { P } \\ \text { GROUPNOS } & .175964 E+12 & 4 & .439910 E+11 & 47.380 & 0.000 \\ \text { ERROR } & .659208 E+11 & 71 & .928463 E+09 & & \end{array}$

FRI $1 / 27 / 95 \quad 1: 44: 52$ PM $\quad$ D: ISORWTISORWTDAT.SYS

COL/

ROW GROUPNO\$

1 IV

2 VII

$3 \times I I$

$4 \mathrm{XV}$

$5 X V I$

USING LEAST SQUARES MEANS.

POST HOC TEST OF NO3

USING MODEL MSE OF ***** WITH 71. DF.

MATRIX OF PAIRWISE MEAN DIFFERENCES:

$\begin{array}{rrrrrr} & 1 & 2 & 3 & 4 & 5 \\ 1 & 0.000 & & & & \\ 2 & -129711.111 & 0.000 & & & \\ 3 & -65038.889 & 64672.222 & 0.000 & & \\ 4 & -145062.500 & -15351.389 & -80023.611 & 0.000 & \\ 5 & -41300.000 & 88411.111 & 23738.889 & 103762.500 & 0.000\end{array}$

TUKEY HSD MULTIPLE COMPARISONS.

MATRIX OF PAIRWISE COMPARISON PROBABILITIES:

1

$\begin{array}{ll}1 & 1.000 \\ 2 & 0.000 \\ 3 & 0.000 \\ 4 & 0.000 \\ 5 & 0.006\end{array}$

2

1.000

0.000

0.760

0.000
3

1.000
0.000
0.114
4

5

$\begin{array}{ll}0.000 & 1.000 \\ 0.000 & 0.000 \\ 0.000 & 0.760 \\ 0.006 & 0.000\end{array}$

1.000

0.000 
FRI $1 / 27 / 95 \quad 1: 45: 07$ PM D: ISORWTISORWTDAT.SYS

LEVELS ENCOUNTERED DURING PROCESSING ARE:

GROUPNO\$

IV VII XII $\quad$ XV

32 CASES DELETED DUE TO MISSING DATA.

DEP VAR: NO2 N: $\quad 76$ MULTIPLE R: 0.739 SQUARED MULTIPLE R: 0.546

ANALYSIS OF VARIANCE

$\begin{array}{lccccc}\text { SOURCE } & \text { SUM-OF-SQUARES } & \text { DF } & \text { MEAN-SQUARE } & \text { F-RATIO } & P \\ \text { GROUPNOS } & .812275 E+10 & 4 & .203069 E+10 & 21.381 & 0.000 \\ \text { ERROR } & .674339 E+10 & 71 & .949773 E+08 & & \end{array}$

FRI 1/27/95 1:45:14 PM D:ISORWTISORWTDAT.SYS

COLI

ROW GROUPNOS

1 IV

2 VII

$3 \mathrm{XII}$

$4 \mathrm{XV}$

$5 X V I$

USING LEAST SQUARES MEANS.

POST HOC TEST OF NO2

USING MODEL MSE OF 94977326.797 WITH

MATRIX OF PAIRWISE MEAN DIFFERENCES:

71. DF.

\begin{tabular}{rrrrrr} 
& \multicolumn{1}{c}{1} & \multicolumn{1}{c}{2} & 3 & \multicolumn{1}{c}{4} & \multicolumn{1}{c}{5} \\
1 & 0.000 & & & & \\
2 & -25011.278 & 0.000 & & & \\
3 & -18091.667 & 6919.611 & 0.000 & & \\
4 & -24832.750 & 178.528 & -6741.083 & 0.000 & \\
5 & -2819.545 & 22191.732 & 15272.121 & 22013.205 & 0.000
\end{tabular}

TUKEY HSD MULTIPLE COMPARISONS.

MATRIX OF PAIRWISE COMPARISON PROBABILITIES:

$\begin{array}{llllll} & 1 & 2 & 3 & 4 & 5 \\ 1 & 1.000 & & & & \\ 2 & 0.000 & 1.000 & & & \\ 3 & 0.000 & 0.219 & 1.000 & & \\ 4 & 0.000 & 1.000 & 0.485 & 1.000 & \\ 5 & 0.942 & 0.000 & 0.000 & 0.000 & 1.000\end{array}$


FRI $1 / 27 / 95 \quad 1: 45: 30$ PM D: ISORWT \SORWTDAT.SYS

LEVELS ENCOUNTERED DURING PROCESSING ARE:

GROUPNO\$

IV VII XII $\quad X V \quad X V I$

32 CASES DELETED DUE TO MISSING DATA.

DEP VAR: $\quad \mathrm{F} \quad \mathrm{N}: \quad 76$ MULTIPLE $R: 0.960$ SQUARED MULTIPLE R: 0.921

ANALYSIS OF VARIANCE

$\begin{array}{lccccc}\text { SOURCE } & \text { SUM-OF-SQUARES } & \text { DF } & \text { MEAN-SQUARE } & \text { F-RATIO } & \text { P } \\ \text { GROUPNOS } & .689270 E+09 & 4 & .172318 E+09 & 206.385 & 0.000 \\ \text { ERROR } & .592803 E+08 & 71 & 834933.824 & & \end{array}$

FRI 1/27/95 1:45:43 PM D:ISORWT ISORWTDAT.SYS

COL/

ROW GROUPNO\$

1 IV

2 VII

$3 \mathrm{XII}$

$4 \quad X V$

$5 X Y I$

USING LEAST SQUARES MEANS.

POST HOC TEST OF $\quad F$

USING MODEL MSE OF 834933.824 WITH 71. DF. MATRIX OF PAIRWISE MEAN DIFFERENCES:

\begin{tabular}{rrrrrr} 
& 1 & \multicolumn{1}{c}{2} & 3 & 4 & \multicolumn{1}{c}{5} \\
1 & 0.000 & & & & \\
2 & 6002.444 & 0.000 & & & \\
3 & 8128.556 & 2126.111 & 0.000 & & \\
4 & 2169.250 & -3833.194 & .5959 .306 & 0.000 & \\
5 & 1629.364 & -4373.081 & .6499 .192 & .539 .886 & 0.000
\end{tabular}

TUKEY HSD MULTIPLE COMPARISONS.

MATRIX OF PAIRWISE COMPARISON PROBABILITIES:

$\begin{array}{llllll} & 1 & 2 & 3 & 4 & 5 \\ 1 & 1.000 & & & & \\ 2 & 0.000 & 1.000 & & & \\ 3 & 0.000 & 0.000 & 1.000 & & \\ 4 & 0.000 & 0.000 & 0.000 & 1.000 & \\ 5 & 0.000 & 0.000 & 0.000 & 0.610 & 1.000\end{array}$


FRI $1 / 27 / 95 \quad 1: 46: 02$ PM D: ISORWTISORWTDAT.SYS LEVELS ENCOUNTERED DURING PROCESSING ARE:

GROUPNO\$

$\begin{array}{lllll}\text { IV } & \text { VII } & \text { XII } & \text { XV } & \text { XVI }\end{array}$

32 CASES DELETED DUE TO MISSING DATA.

DEP VAR: $\quad \mathrm{CL} \quad \mathrm{N}: \quad 76$ MULTIPLE R: 0.926 SQUARED MULTIPLE R: 0.857

ANALYSIS OF VARIANCE

$\begin{array}{lccccc}\text { SOURCE } & \text { SUM-OF-SQUARES } & \text { DF } & \text { MEAN-SQUARE } & \text { F-RATIO } & \text { P } \\ \text { GROUPNO\$ } & .414409 E+08 & 4 & .103602 E+08 & 106.625 & 0.000 \\ \text { ERROR } & 6898701.915 & 71 & 97164.816 & & \end{array}$

FRI 1/27/95 1:46:06 PM D: ISORWTISORWTDAT.SYS

COL/

ROW GROUPNOS

1 IV

2 VII

$3 \mathrm{XII}$

$4 \mathrm{XV}$

$5 \quad X V I$

USING LEAST SQUARES MEANS.

POST HOC TEST OF $\quad$ CL

USING MODEL MSE OF $97164.816 \mathrm{WITH}$ 71. DF. MATRIX OF PAIRWISE MEAN DIFFERENCES:

\begin{tabular}{rrrrrr} 
& \multicolumn{1}{c}{1} & \multicolumn{1}{c}{2} & \multicolumn{1}{c}{3} & \multicolumn{1}{c}{4} & \multicolumn{1}{l}{5} \\
1 & 0.000 & & & & \\
2 & -1937.389 & 0.000 & & & \\
3 & -2045.556 & -108.167 & 0.000 & & \\
4 & -.2712 .375 & -774.986 & -666.819 & 0.000 & \\
5 & -2009.409 & -72.020 & 36.146 & 702.966 & 0.000
\end{tabular}

TUKEY HSD MULTIPLE COMPARISONS.

MATRIX OF PAIRWISE COMPARISON PROBABILITIES:

$\begin{array}{llllll} & 1 & 2 & 3 & 4 & 5 \\ 1 & 1.000 & & & & \\ 2 & 0.000 & 1.000 & & & \\ 3 & 0.000 & 0.835 & 1.000 & & \\ 4 & 0.000 & 0.000 & 0.000 & 1.000 & \\ 5 & 0.000 & 0.950 & 0.996 & 0.000 & 1.000\end{array}$


FRI $1 / 27 / 95 \quad 1: 46: 34$ PM D: ISORWTISORWTDAT.SYS

LEVELS ENCOUNTERED DURING PROCESSING ARE:

GROUPNO\$

IV VII XII XV XVI

45 CASES DELETED DUE TO MISSING DATA.

DEP VAR: TOC N: 63 MULTIPLE R: 0.520 SQUARED MULTIPLE R: 0.271

ANALYSIS OF VARIANCE

$\begin{array}{lccccc}\text { SOURCE } & \text { SUM-OF-SQUARES } & \text { DF } & \text { MEAN-SQUARE } & \text { F-RATIO } & P \\ \text { GROUPNOS } & .520472 E+09 & 4 & .130118 E+09 & 5.381 & 0.001 \\ \text { ERROR } & .140262 E+10 & 58 & .241831 E+08 & & \end{array}$

FRI $1 / 27 / 95$ 1:46:45 PM D: ISORWTISORWTDAT.SYS

COLI

ROW GROUPNO\$

$\begin{array}{ll}1 & \text { IV } \\ 2 & V I I \\ 3 & X I I \\ 4 & X V \\ 5 & X V I\end{array}$

USING LEAST SQUARES MEANS.

POST HOC TEST OF TOC

USING MODEL MSE OF 24183079.245 WITH 58. DF.

MATRIX OF PAIRWISE MEAN DIFFERENCES:

\begin{tabular}{rrrrrr} 
& \multicolumn{1}{c}{1} & \multicolumn{1}{c}{2} & 3 & \multicolumn{1}{c}{4} & \multicolumn{1}{l}{5} \\
1 & 0.000 & & & & \\
2 & 7162.000 & 0.000 & & & \\
3 & -867.462 & -8029.462 & 0.000 & & \\
4 & 1512.750 & -5649.250 & 2380.212 & 0.000 & \\
5 & -972.500 & -8134.500 & -105.038 & -2485.250 & 0.000
\end{tabular}

TUKEY HSD MULTIPLE COMPARISONS.

MATRIX OF PAIRWISE COMPARISON PROBABILITIES:

$\begin{array}{llllll} & 1 & 2 & 3 & 4 & 5 \\ 1 & 1.000 & & & & \\ 2 & 0.016 & 1.000 & & & \\ 3 & 0.993 & 0.003 & 1.000 & & \\ 4 & 0.966 & 0.124 & 0.818 & 1.000 & \\ 5 & 0.985 & 0.001 & 1.000 & 0.738 & 1.000\end{array}$


FRI $1 / 27 / 95 \quad 1: 47: 13$ PM D: ISORWTISORWTDAT.SYS

LEVELS ENCOUNTERED DURING PROCESSING ARE:

GROUPNOS

IV

XII XV XVI

70 CASES DELETED DUE TO MISSING DATA.

DEP VAR: $\quad \mathrm{PH} \quad \mathrm{N}: \quad 38$ MULTIPLE R: 0.939 SQUARED MULTIPLE R: 0.882

ANALYSIS OF VARIANCE

$\begin{array}{lrrrrc}\text { SOURCE } & \text { SUM-OF-SQUARES } & \text { DF } & \text { MEAN-SQUARE } & \text { F-RATIO } & \text { P } \\ \text { GROUPNO } & 121.793 & 3 & 40.598 & 84.879 & 0.000 \\ \text { ERROR } & 16.262 & 34 & 0.478 & & \end{array}$

FRI $1 / 27 / 95 \quad 1: 47: 19$ PM D: ISORWTISORWTDAT.SYS

$\mathrm{COL} /$

ROW GROUPNO\$

1 IV

$2 X I I$

3 XV

$4 X V I$

USING LEAST SQUARES MEANS.

POST HOC TEST OF PH

USING MODEL MSE OF .478 WITH 34. DF.

MATRIX OF PAIRWISE MEAN DIFFERENCES:

$\begin{array}{lllll} & 1 & 2 & 3 & 4 \\ 1 & 0.000 & & & \\ 2 & -2.172 & 0.000 & & \\ 3 & -1.153 & 1.019 & 0.000 & \\ 4 & -4.582 & -2.411 & -3.429 & 0.000\end{array}$

TUKEY HSD MULTIPLE COMPARISONS.

MATRIX OF PAIRWISE COMPARISON PROBABILITIES:

$\begin{array}{lllll} & 1 & 2 & 3 & 4 \\ 1 & 1.000 & & & \\ 2 & 0.000 & 1.000 & & \\ 3 & 0.398 & 0.494 & 1.000 & \\ 4 & 0.000 & 0.000 & 0.000 & 1.000\end{array}$


MON 7/25/94 4:21:51 PM D: ISORWT \DENSITY.SYS

LEVELS ENCOUNTERED DURING PROCESSING ARE:

GROUPNO\$

$\begin{array}{lllll}V & X I & X I & X I V\end{array}$

16 CASES DELETED DUE TO MISSING DATA.

DEP VAR: DENSITY $\quad \mathrm{N}: \quad 59$ MULTIPLE R: 0.712 SQUARED MULTIPLE R: 0.507

ANALYSIS OF VARIANCE

SOURCE SUM-OF-SQUARES DF MEAN-SQUARE F-RATIO P

$\begin{array}{llllll}\text { GROUPNO\$ } & 0.645 & 4 & 0.161 & 13.893 & 0.000\end{array}$

$\begin{array}{llll}\text { ERROR } & 0.626 & 54 & 0.012\end{array}$

MON 7/25/94 4:21:59 PM D: ISORWTIDENSITY.SYS

$\mathrm{COL} /$

ROW GROUPNO\$

$\begin{array}{ll}1 & V \\ 2 & V I \\ 3 & X I \\ 4 & X I V \\ 5 & X V\end{array}$

USING LEAST SQUARES MEANS.

POST HOC TEST OF DENSITY

USING MODEL MSE OF

MATRIX OF PAIRWISE MEAN DIFFERENCES:

$\begin{array}{llllll} & 1 & 2 & 3 & 4 & 5 \\ 1 & 0.000 & & & & \\ 2 & 0.554 & 0.000 & & & \\ 3 & 0.289 & -0.265 & 0.000 & & \\ 4 & 0.149 & -0.405 & -0.140 & 0.000 & \\ 5 & 0.185 & -0.369 & -0.104 & 0.036 & 0.000\end{array}$

TUKEY HSD MULTIPLE COMPARISONS.

MATRIX OF PAIRWISE COMPARISON PROBABILITIES:

$\begin{array}{llllll} & 1 & 2 & 3 & 4 & 5 \\ 1 & 1.000 & & & & \\ 2 & 0.000 & 1.000 & & & \\ 3 & 0.000 & 0.195 & 1.000 & & \\ 4 & 0.357 & 0.027 & 0.566 & 1.000 & \\ 5 & 0.000 & 0.011 & 0.362 & 0.991 & 1.000\end{array}$




\section{Appendix F}

Descriptive Statistics of Core Sample Analytical Data Used in the SORWT Model Verification Study 

FRI 1/27/95 2:10:58 PM D: ISORWT ISORWT_S.SYS

THE FOLLOWING RESULTS ARE FOR: GROUPNO\$ $=$ IV

TOTAL OBSERVATIONS: 12

$\begin{array}{lllll}\text { AL } & \text { BI } & \text { CR } & \text { FE } & \text { LA }\end{array}$

$\begin{array}{lr}\text { N OF CASES } & 12 \\ \text { MINIMUM } & 111000.000 \\ \text { MAXIMUM } & 123000.000 \\ \text { RANGE } & 12000.000 \\ \text { MEAN } & 117000.000 \\ \text { VARIANCE } & .160000 \text { E }+08 \\ \text { STANDARD DEV } & 4000.000 \\ \text { STD. ERROR } & 1154.701 \\ \text { SKEWNESS(G1) } & 0.151 \\ \text { KURTOSIS(G2) } & -1.263 \\ \text { SUM } & 1404000.000 \\ \text { C.V. } & 0.034 \\ \text { MEDIAN } & 116500.000\end{array}$

$$
\begin{array}{r}
12 \\
28.600 \\
45.700 \\
17.100 \\
38.775 \\
55.569 \\
7.454 \\
2.152 \\
-0.604 \\
-1.498 \\
465.300 \\
0.192 \\
42.150
\end{array}
$$

N OF CASES

MINIMUM

MAXIMUM

RANGE

MEAN

VARIANCE

STANDARD DEV

STD. ERROR

SKEWNESS(G1)

KURTOSIS (G2)

SUM

C.V.

MEDIAN

N OF CASES
MINIMUM
MAXIMUM
RANGE
MEAN
VARIANCE
STANDARD DEV
STD. ERROR
SKEWNESS(G1)
KURTOSIS(G2)
SUM
C.V.
MEDIAN

$N$ OF CASES

MINIMUM

MAXIMUM

RANGE

MEAN

VARIANCE

STANDARD DEV

STD. ERROR

SKEWNESS (G1)

KURTOSIS (G2)

SUM

C.V.

MEDIAN
NA

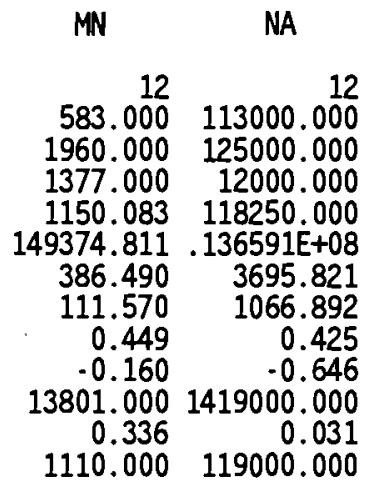

PB

35.000

42.500

7.500

38.625

8.682

2.947

0.851

0.118

$-1.486$

463.500

0.076

38.350

\section{$\begin{array}{llr}\text { CS137 } & \text { SR90 PU23940 }\end{array}$}

$$
\begin{array}{r}
12 \\
55.700 \\
67.500 \\
11.800 \\
62.308 \\
10.783 \\
3.284 \\
0.948 \\
-0.434 \\
-0.307 \\
747.700 \\
0.053 \\
62.850
\end{array}
$$

N03

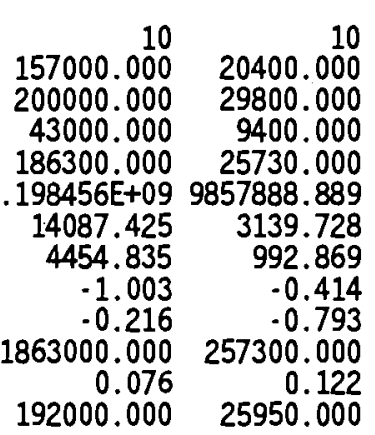

272.000

356.000

84.000

309.583

634.992

25.199

7.274

0.522

0.081

304.000

NO2

10

108.000

219.000

111.000

132.000

2090.667

45.724

14.459

1.479

0.219

1320.000

0.346

109.500
3715.000
16.700

1900.000

1883.300

1423.775

446681.986

668.343

192.934

$-1.655$

0.956

17085.300

0.469

1675.000

SI

12
947.000
2310.000
1363.000
1326.417
139466.811
373.453
107.806
1.550
2.009
15917.000
0.282
1205.000

U

12
5150.000
7530.000
2380.000
6685.000
469627.273
685.294
197.827
-0.721
0.081
80220.000
0.103
6710.000

CL

10
2950.000

3520.000

570.000

3162.000

25306.667

159.081

50.306

0.948

0.723

31620.000

0.050

3135.000
ZR

P04

$$
\begin{array}{r}
12 \\
7.890 \\
10.500 \\
2.610 \\
9.413 \\
1.217 \\
1.103 \\
0.318 \\
-0.553 \\
-1.495 \\
112.950 \\
0.117 \\
9.840
\end{array}
$$

$$
\begin{array}{r}
12 \\
4.850 \\
37.900 \\
33.050 \\
21.207 \\
96.568 \\
9.827 \\
2.837 \\
-0.127 \\
-0.904 \\
254.480 \\
0.463 \\
21.900
\end{array}
$$

10

1080.000

1110.000

1310.000

212733.333

461.230

145.854

1.499

0.249

13100.000

0.352

1095.000

TOC

1090.000

2380.000

1290.000

1606.000

315382.222

561.589

177.590

0.425

$-1.667$

16060.000

0.350

1300.000 
THE FOLLOWING RESULTS ARE FOR:

GROUPNOS $=$ VII

TOTAL OBSERVATIONS: 22

$\begin{array}{lllll}\text { AL } & \text { BI } & \text { CR } & \text { FE } & \text { LA }\end{array}$

N OF CASES
MINIMUM
MAXIMUM
RANGE
MEAN
VARIANCE
STANDARD DEV
STD. ERROR
SKEWNESS(G1)
KURTOSIS(G2)
SUM
C.V.
MEDIAN

$\begin{array}{rr}17 & 17 \\ 195.000 & 27189.000 \\ 13071.000 & 105375.000 \\ 12876.000 & 78186.000 \\ 3490.000 & 61753.471 \\ 320602 \mathrm{E}+08 & .106507 \mathrm{E}+10 \\ 4696.825 & 32635.396 \\ 1139.147 & 7915.246 \\ 1.265 & 0.156 \\ -0.268 & -1.888 \\ 59330.000 & 1049809.000 \\ 1.346 & 0.528 \\ 1168.000 & 36591.000\end{array}$

$\begin{array}{rrr}17 & 17 & 17 \\ 1875.000 & 3630.000 & 11424.000 \\ 3875.000 & 18712.000 & 15599.000 \\ 2000.000 & 15082.000 & 4175.000 \\ 2835.000 & 10155.647 & 13591.529 \\ 390714.625 & .244163 \mathrm{E}+08 & 1562411.890 \\ 625.072 & 4941.290 & 1249.965 \\ 151.602 & 1198.439 & 303.161 \\ 0.130 & 0.344 & -0.002 \\ -1.146 & -1.001 & -1.043 \\ 48195.000 & 172646.000 & 231056.000 \\ 0.220 & 0.487 & 0.092 \\ 2787.000 & 10138.000 & 13170.000\end{array}$

N OF CASES
MINIMUM
MAXIMMM
RANGE
MEAN
VARIANCE
STANDAR DEV
STD. ERROR
SKEWESS(G1)
KURTOSIS(G2)
SUM
C.V.
MEDIAN

\begin{tabular}{rr}
\multicolumn{1}{c}{ MN } & \multicolumn{1}{c}{ NA } \\
17 & 17 \\
800.000 & 33576.000 \\
25880.000 & 58510.000 \\
25080.000 & 24934.000 \\
14508.711 & 41364.059 \\
$.694385 E+08$ & $.722929 E+08$ \\
8332.975 & 8502.523 \\
2021.043 & 2062.165 \\
-0.251 & 1.128 \\
-1.113 & -0.419 \\
246644.000 & 703189.000 \\
0.574 & 0.206 \\
12800.000 & 37896.000
\end{tabular}

\begin{tabular}{rrr}
\multicolumn{1}{c}{ PB } & \multicolumn{1}{c}{ SI } & \multicolumn{1}{c}{ ZR } \\
17 & 17 & 17 \\
334.000 & 1130.000 & 3.900 \\
2244.000 & 59723.000 & 82.400 \\
1910.000 & 58593.000 & 78.500 \\
1124.529 & 15648.176 & 28.912 \\
16589.015 & $.442815 \mathrm{E}+09$ & 768.351 \\
645.437 & 21043.163 & 27.719 \\
156.541 & 5103.717 & 6.723 \\
0.406 & 1.281 & 0.582 \\
-1.119 & -0.196 & -1.050 \\
19117.000 & 266019.000 & 491.500 \\
0.574 & 1.345 & 0.959 \\
833.000 & 5849.000 & 7.000
\end{tabular}

$\begin{array}{lllll}\text { CS137 } & \text { SR90 } & \text { PU23940 } & U & \text { P04 }\end{array}$

N OF CASES
MINIMUM
MAXIMUM
RANGE
MEAN
VARIANCE
STANDARD DEV
STD. ERROR
SKEWNESS(G1)
KURTOSIS(G2)
SUM
C.V.
MEDIAN

$$
\begin{aligned}
& 18 \\
& 0.011 \\
& 1.610 \\
& 1.599 \\
& 0.403 \\
& 0.200 \\
& 0.447 \\
& 0.105 \\
& 1.169 \\
& 0.849 \\
& 7.260 \\
& 1.109 \\
& 0.300
\end{aligned}
$$

18

0.830

7.370
6.540

3.168

3.555

1.886

0.444

0.747

$-0.340$

57.030

0.595

2.740

N03

N02

18
0.118
1.560

1.442

0.606

0.296

0.544

0.128

0.719

$-1.070$

10.908

0.897

0.285

18
119.000
860.000
741.000
413.944
53980.173
232.336
54.762
0.567
-1.094
7451.000
0.561
322.000

18

1000.000

2730.000

1730.000

1705.722

243377.624

493.333

116.280

0.266

30703.000

0.289

1730.000

N OF CASES
MINIMUM
MAXIMUM
RANGE
MEAN
VARIANCE
STANDARD DEV
STD. ERROR
SKEWNESS(G1)
KURTOSIS(G2)
SUM
C.V.
MEDIAN

47000.000

71300.000

24300.000

56588.889

$.547446 \mathrm{E}+08$

7398.958

1743.951

0.361

$-1.060$

1018600.000

0.131

56850.000



CL

TOC

$$
\begin{array}{r}
18 \\
5200.000 \\
7200.000 \\
2000.000 \\
6134.444 \\
198802.614 \\
445.873 \\
105.093 \\
0.338 \\
0.662 \\
110420.000 \\
0.073 \\
6090.000
\end{array}
$$

CL TOC

$\begin{array}{rr}18 & 10 \\ 646.000 & 1900.000 \\ 2000.000 & 33200.000 \\ 1354.000 & 31300.000 \\ 1224.611 & 8768.000 \\ 216320.958 & .154537 \mathrm{E}+09 \\ 465.103 & 12431.308 \\ 109.626 & 3931.125 \\ 0.088 & 1.491 \\ -1.461 & 0.253 \\ 22043.000 & 87680.000 \\ 0.380 & 1.418 \\ 1240.000 & 3505.000\end{array}$


THE FOLLOWING RESULTS ARE FOR:

$$
\text { GROUPNO\$ }=\text { XII }
$$

TOTAL OBSERVATIONS: 18

\begin{tabular}{|c|c|c|c|c|c|}
\hline & AL & I & $\mathbf{R}$ & FE & LA \\
\hline \multirow[t]{2}{*}{$\begin{array}{l}\text { N OF CASES } \\
\text { MINIMUM } \\
\text { MAXIMUM } \\
\text { RANGE } \\
\text { MEAN } \\
\text { VARIANCE } \\
\text { STANDARD DEV } \\
\text { STD. ERROR } \\
\text { SKEENESS(G1) } \\
\text { KURTOSIS(G2) } \\
\text { SUM } \\
\text { C.V. } \\
\text { MEDIAN }\end{array}$} & $\begin{array}{r}18 \\
11200.000 \\
17300.000 \\
6100.000 \\
14322.566 \\
1998942.011 \\
1413.839 \\
333.245 \\
0.318 \\
0.908 \\
257806.190 \\
0.099 \\
14300.000\end{array}$ & $\begin{array}{r}18 \\
10200.000 \\
28200.000 \\
18000.000 \\
17355.556 \\
.281097 \mathrm{E}+08 \\
5301.856 \\
1249.659 \\
0.773 \\
.0 .410 \\
312400.000 \\
0.305 \\
15400.000\end{array}$ & $\begin{array}{r}18 \\
413.000 \\
1080.000 \\
667.000 \\
685.000 \\
72523.882 \\
269.303 \\
63.475 \\
0.349 \\
-1.693 \\
12330.000 \\
0.393 \\
495.500\end{array}$ & $\begin{array}{r}8350.0 \\
13400.0 \\
5050.0 \\
10811.6 \\
1977720.5 \\
1406.3 \\
331.4 \\
0.0 \\
.0 .7 \\
194610.0 \\
0.1 \\
11200.0\end{array}$ & $\begin{array}{r}18 \\
7.890 \\
8.000 \\
0.110 \\
7.967 \\
0.001 \\
0.029 \\
0.007 \\
-1.312 \\
1.262 \\
43.410 \\
0.004 \\
7.980\end{array}$ \\
\hline & MN & NA & PB & SI & ZR \\
\hline \multirow[t]{2}{*}{$\begin{array}{l}\text { N OF CASES } \\
\text { MINIMUM } \\
\text { MAXIMUM } \\
\text { RANGE } \\
\text { MEAN } \\
\text { VARIANCE } \\
\text { STANDARD DEV } \\
\text { STD. ERROR } \\
\text { SKENESS(G1) } \\
\text { KURTOSIS(G2) } \\
\text { SUM } \\
\text { C.V. } \\
\text { MEDIAN }\end{array}$} & $\begin{array}{r}18 \\
31.000 \\
93.400 \\
62.400 \\
58.111 \\
299.810 \\
17.315 \\
4.081 \\
0.299 \\
-0.482 \\
1046.000 \\
0.298 \\
57.450\end{array}$ & $\begin{array}{r}78 \\
73900.000 \\
106000.000 \\
32100.000 \\
91133.333 \\
.914647 \mathrm{E}+08 \\
9563.718 \\
2254.190 \\
-0.004 \\
-1.205 \\
1640400.000 \\
-0.105 \\
88450.000\end{array}$ & $\begin{array}{r}18 \\
35.400 \\
461.000 \\
425.600 \\
181.456 \\
22577.901 \\
150.259 \\
35.416 \\
1.039 \\
-0.570 \\
3266.200 \\
0.828 \\
120.500\end{array}$ & $\begin{array}{r}18 \\
5630.000 \\
7990.000 \\
2360.000 \\
6932.778 \\
531574.183 \\
729.091 \\
171.848 \\
0.006 \\
.1 .280 \\
124790.000 \\
0.105 \\
6870.000\end{array}$ & $\begin{array}{r}18 \\
53.400 \\
201.000 \\
147.600 \\
152.978 \\
2032.682 \\
45.085 \\
10.627 \\
-1.031 \\
.0 .042 \\
2753.600 \\
0.295 \\
169.500\end{array}$ \\
\hline & 137 & SR90 & 123940 & $U$ & PO4 \\
\hline \multirow[t]{2}{*}{$\begin{array}{l}\text { N OF CASES } \\
\text { MINIMUM } \\
\text { MAXIMUM } \\
\text { RANGE } \\
\text { MEAN } \\
\text { VARIANCE } \\
\text { STANDARD DEV } \\
\text { STD. ERROR } \\
\text { SKEENESS(G1) } \\
\text { KURTOSIS(G2) } \\
\text { SUM } \\
\text { C.V. } \\
\text { MEDIAN }\end{array}$} & $\begin{array}{r}18 \\
10.900 \\
25.100 \\
14.200 \\
18.533 \\
23.805 \\
4.879 \\
1.150 \\
.0 .087 \\
-1.481 \\
333.600 \\
0.263 \\
19.550\end{array}$ & $\begin{array}{r}18 \\
2.590 \\
12.000 \\
9.410 \\
7.188 \\
8.643 \\
2.940 \\
0.693 \\
0.034 \\
-1.166 \\
129.390 \\
0.409 \\
7.180\end{array}$ & $\begin{array}{l}18 \\
0.035 \\
0.153 \\
0.118 \\
0.070 \\
0.001 \\
0.030 \\
0.007 \\
1.695 \\
2.096 \\
1.258 \\
0.432 \\
0.057\end{array}$ & $\begin{array}{r}18 \\
943.000 \\
25200.000 \\
24257.000 \\
4248.500 \\
.523516 \mathrm{E}+08 \\
7235.439 \\
1705.409 \\
2.462 \\
4.147 \\
76473.000 \\
1.703 \\
1970.000\end{array}$ & $\begin{array}{r}18 \\
13400.000 \\
49300.000 \\
35900.000 \\
22255.556 \\
.135458 \mathrm{E}+09 \\
11638.639 \\
2743.253 \\
1.160 \\
-0.178 \\
400600.000 \\
0.523 \\
15950.000\end{array}$ \\
\hline & $\mathrm{NO3}$ & N02 & $F$ & $C L$ & TOC \\
\hline $\begin{array}{l}\text { N OF CASES } \\
\text { MINIMUM } \\
\text { MAXIMUM } \\
\text { RANGE } \\
\text { MEAN } \\
\text { VARIANCE } \\
\text { STANDARD DEV } \\
\text { STD. ERROR } \\
\text { SKEWNESS(G1) } \\
\text { KURTOSIS(G2) } \\
\text { SUM } \\
\text { C.V. } \\
\text { MEDIAN }\end{array}$ & $\begin{array}{r}18 \\
91400.000 \\
153000.000 \\
61600.000 \\
121261.111 \\
.329647 \mathrm{E}+09 \\
18156.190 \\
4279.455 \\
-0.064 \\
-0.837 \\
2182700.000 \\
0.150 \\
122000.000\end{array}$ & $\begin{array}{r}1180.000 \\
13500.000 \\
12320.000 \\
7638.333 \\
.211695 \mathrm{E}+08 \\
4601.031 \\
1084.473 \\
-0.131 \\
1 . .610 \\
137490.000 \\
0.602 \\
9145.000\end{array}$ & $\begin{array}{r}18 \\
4330.000 \\
11000.000 \\
6670.000 \\
8260.556 \\
2894146.732 \\
1701.219 \\
400.981 \\
-0.779 \\
0.625 \\
148690.000 \\
0.206 \\
8550.000\end{array}$ & $\begin{array}{r}661 . \\
2020 . \\
1359 . \\
1116 . \\
137326 . \\
370 . \\
87 . \\
1 . \\
1 . \\
20096 . \\
0 . \\
1105 .\end{array}$ & $\begin{array}{r}500.000 \\
1090.000 \\
590.000 \\
738.538 \\
56825.103 \\
238.380 \\
66.115 \\
0.498 \\
-1.417 \\
9601.000 \\
0.323 \\
700.000\end{array}$ \\
\hline
\end{tabular}


THE FOLLOWING RESULTS ARE FOR: GROUPNO\$ $=\mathrm{XV}$

TOTAL OBSERVATIONS: 8

N OF CASES
MINIMUM
MAXIMUM
RANGE
MEAN
VARIANCE
STANDARD DEV
STD. ERROR
SKEWNESS(G1)
KURTOSIS(G2)
SUM
C.V.
MEDIAN

N OF CASES
MINIMUM
MAXIMUM
RANGE
MEAN
VARIANCE
STANDARD DEV
STD. ERROR
SKEWNESS(G1)
KURTOSIS(G2)
SUM
C.V.
MEDIAN

N OF CASES

\section{MINIMUM}

MAXIMUM

RANGE

MEAN

VARIANCE

STANDARD DEV

STD. ERROR

SKEWNESS (G1)

KURTOSIS (G2)

SUM

C. Y

MEDIAN

N OF CASES
MINIMUM
MAXIMUM
RANGE
MEAN
VARIANCE
STANDARD DEV
STD. ERROR
SKEWNESS(G1)
KURTOSIS(G2)
SUM
C.V.
MEDIAN

$$
\begin{array}{rrrrrr}
\multicolumn{1}{r}{\text { AL }} & \multicolumn{1}{c}{\text { BI }} & \multicolumn{1}{c}{\text { CR }} & \multicolumn{1}{c}{\text { FE }} & \multicolumn{1}{l}{\text { LA }} \\
8 & & 8 & 8 & 8 \\
459.000 & 20100.000 & 1670.000 & 15700.000 & 3380.000 \\
706.000 & 27300.000 & 1920.000 & 20800.000 & 4840.000 \\
247.000 & 7200.000 & 250.000 & 5100.000 & 1460.000 \\
570.000 & 23562.500 & 1798.750 & 18037.500 & 4107.500 \\
11610.286 & .106398 E+08 & 6041.071 & 4794107.143 & 378107.143 \\
107.751 & 3261.874 & 77.724 & 2189.545 & 614.904 \\
38.096 & 1153.247 & 27.480 & 774.121 & 217.401 \\
0.087 & -0.006 & -0.158 & 0.078 & 0.012 \\
-1.824 & -1.905 & -0.629 & -1.851 & -1.754 \\
4560.000 & 188500.000 & 14390.000 & 144300.000 & 32860.000 \\
0.189 & 0.138 & 0.043 & 0.121 & 0.150 \\
558.500 & 23750.000 & 1815.000 & 17850.000 & 4100.000
\end{array}
$$

MN

$$
\begin{array}{rr}
8 & 8 \\
5860.000 & 33600.000 \\
6590.000 & 40100.000 \\
730.000 & 6500.000 \\
6282.500 & 36950.000 \\
69907.143 & 7311428.571 \\
264.400 & 2703.965 \\
93.479 & 955.996 \\
-0.257 & -0.032 \\
-1.128 & -1.770 \\
50260.000 & 295600.000 \\
0.042 & 0.073 \\
6290.000 & 36850.000
\end{array}
$$

CS137

$$
\begin{array}{r}
8 \\
0.103 \\
0.238 \\
0.135 \\
0.166 \\
0.004 \\
0.063 \\
0.022 \\
0.059 \\
-1.893 \\
1.331 \\
0.377 \\
0.163
\end{array}
$$

N03

$$
\begin{array}{r}
8 \\
36100.000 \\
44500.000 \\
8400.000 \\
41237.500 \\
.05827 \mathrm{E}+08 \\
3253.103 \\
1150.146 \\
-0.432 \\
-1.340 \\
329900.000 \\
0.079
\end{array}
$$

41950.000
NA

SR90

PU23940

$$
\begin{array}{r}
8 \\
3.370 \\
7.550 \\
4.180 \\
5.414 \\
4.067 \\
2.017 \\
0.713 \\
0.012 \\
-1.969 \\
43.310 \\
0.372 \\
5.320
\end{array}
$$

NO2

704.000

1100.000

396.000

897.250

31437.071

177.305

62.687

0.205

$-1.651$

7178.000

0.198

856.500

PB

$\begin{array}{rr}8 & 8 \\ 1670.000 & 15700.000 \\ 1920.000 & 20800.000 \\ 250.000 & 5100.000 \\ 1798.750 & 18037.500 \\ 6041.071 & 4794107.143 \\ 77.724 & 2189.545 \\ 27.480 & 774.121 \\ -0.158 & 0.078 \\ -0.629 & -1.851 \\ 14390.000 & 144300.000 \\ 0.043 & 0.121 \\ 1815.000 & 17850.000\end{array}$

SI

8
262.000
486.000
224.000
365.125
1061.268
105.173
37.184
0.082
-1.892
2921.000
0.288
349.500

5090.000

6040.000

950.000

5565.000

96771.429

311.081

109.984

0.144

$-0.980$

44520.000

0.056

5465.000

U

$\begin{array}{rr}8 & \cdot 8 \\ 0.129 & 240.000\end{array}$

$0.153 \quad 4000.000$

0.024

0.139

0.000

0.007

0.003

0.786

0.273

1.110

0.051

0.138

3760.000

2555.000

1513285.714
1230.157

434.926

$-0.628$

.0 .440

20440.000

0.481

2610.000

$F$

1260.000

3160.000

1900.000

2301.250

753383.929

867.977

306.876

$-0.050$

$-1.914$

18410.000

0.377

2350.000
CL

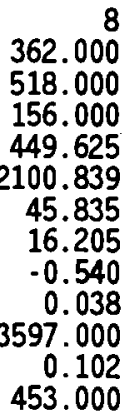

ZR

8
3.990
4.010
0.020
3.996
0.000
0.007
0.003
0.660
-0.739
31.970
0.002
3.995

P04

13500.000

17700.000

4200.000

15537.500

108392.857

1551.900

548.679

$-0.019$

$-1.280$

124300.000

0.100

15350.000

TOC

2000.000

4120.000

2120.000

3118.750

630926.786

794.309

280.831

$-0.374$

$-1.144$

24950.000

0.255 
THE FOLLOWING RESULTS ARE FOR: GROUPNOS $=$ XVI

TOTAL OBSERVATIONS: 48

N OF CASES
MINIMUM
MAXIMUM
RANGE
MEAN
VARIANCE
STANDARD DEV
STD. ERROR
SKEWNESS(G1)
KURTOSIS(G2)
SUM
C.V.
MEDIAN

N OF CASES

MINIMUM

MAXIMUM

RANGE

MEAN

VARIANCE

STANDARD DEV

STD. ERROR

SKEWNESS (G1)

KURTOSIS(G2)

SUM

C.V.

MEDIAN

N OF CASES
MINIMUM
MAXIMUM
RANGE
MEAN
VARIANCE
STANDARD DEV
STD. ERROR
SKEWNESS(G1)
KURTOSIS(G2)
SUM
C.V.
MEDIAN

N OF CASES
MINIMUM
MAXIMUM
RANGE
MEAN
VARIANCE
STANDARD DEV
STD. ERROR
SKEWNESS (G1)
KURTOSIS(G2)
SUM
C. V.
MEDIAN

\begin{tabular}{rr} 
AL & \multicolumn{1}{c}{ BI } \\
48 & 48 \\
339.000 & 14093.000 \\
5860.000 & 23643.000 \\
5521.000 & 9550.000 \\
1424.771 & 19353.792 \\
971945.712 & 6088799.445 \\
985.873 & 2467.549 \\
142.299 & 356.160 \\
2.658 & -0.351 \\
8.235 & -0.508 \\
68389.000 & 928982.000 \\
0.692 & 0.127 \\
1218.000 & 19852.500
\end{tabular}

MN

NA

48
57.000

176.000

119.000

97.229

640.946

25.317

3.654

0.782

0.762

4667.000
0.260

95.000

CS137

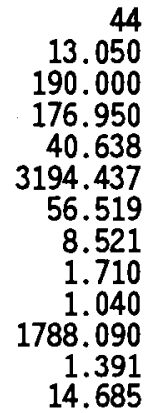

N03

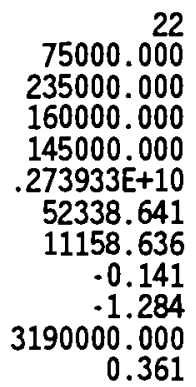

164500.000
48
88030.000

117806.000

29776.000

96358.813

$340031 \mathrm{E}+08$

5831.216

841.664

1.530

2.608

4625223.000

0.061

94877.500

SR90

$$
\begin{array}{r}
30 \\
6.441 \\
337.000 \\
330.559 \\
133.436 \\
10041.561 \\
100.208 \\
18.295 \\
0.418 \\
-1.102 \\
4003.088 \\
0.751 \\
117.550
\end{array}
$$

N02

8870.000

50000.000

41130.000

22910.455

$299707 \mathrm{E}+09$

17312.048

3690.941

0.632

.1 .499

504030.000

0.756

11050.000

$$
\begin{array}{rr}
\multicolumn{1}{c}{\text { CR }} & \multicolumn{1}{c}{\text { FE }} \\
48 & 48 \\
730.000 & 1890.000 \\
1193.000 & 28417.000 \\
463.000 & 26527.000 \\
853.896 & 17486.104 \\
19302.819 & .108591 \mathrm{E}+08 \\
138.935 & 3295.318 \\
20.053 & 475.638 \\
1.501 & -1.906 \\
0.785 & 11.650 \\
40987.000 & 839333.000 \\
0.163 & 0.188 \\
803.500 & 17984.500
\end{array}
$$

LA

PB

SI

48
43.200
1927.000

1883.800

749.929

301486.533

549.078

79.253

1.012

$-0.051$

35996.600

0.732

544.500

PU23940

U

8171.48

23916.000

15745.000

10173.396

7224131.648

2687.774

387.947

3.584

13.898

488323.000

0.264

9467.500

30
0.069
0.158
0.089
0.107
0.000
0.020
0.004
0.297
0.448
3.215
0.185
0.109

34
136.000

283.000

147.000

209.029

1181.423
34.372

5.895

0.289

$-0.100$

7107.000

0.164

205.500

CL

1360.22

2290.000

930.000

1761.364

67031.385

258.904

55.199

0.533

$-0.850$

38750.000

0.147

1650.000
987.000

1500.000

513.000

1152.591

30677.206

175.149

37.342

0.811

.0 .851

25357.000

0.152

1065.000
TOC

ZR

$$
\begin{array}{r}
17.100 \\
829.000 \\
811.900 \\
133.749 \\
45812.918 \\
214.040 \\
30.894 \\
2.058 \\
2.853 \\
6419.940 \\
1.600 \\
49.250
\end{array}
$$

P04

21800.000

28500.000

6700.000

24554.545

2666406.926

1632.914

348.138

0.719

540200.000

0.067

24200.000

298.000

1620.000

1322.000

633.500

183095.595

427.897

91.228

1.402

0.473

13937.000

0.675
447.500 
FRI 1/27/95 2:12:49 PM D: ISORWTISORWT_S.SYS

ALL Groups

TOTAL OBSERVATIONS: 108

\begin{tabular}{lrr} 
& \multicolumn{1}{c}{ AL } & \multicolumn{1}{c}{ BI } \\
N OF CASES & 103 & 103 \\
MINIMUM & 195.000 & 28.600 \\
MAXIMUM & 123000.000 & 105375.000 \\
RANGE & 122805.000 & 105346.400 \\
MEAN & 17418.303 & 24079.187 \\
VARIANCE & $134928 \mathrm{E}+10$ & $.498349 \mathrm{E}+09$ \\
STANDARD DEV & 36732.517 & 22323.726 \\
STD. ERROR & 3619.362 & 2199.622 \\
SKEWNESS(G1) & 2.307 & 2.418 \\
KURTOSIS(G2) & 3.500 & 5.583 \\
SUM & 1794085.190 & 2480156.300 \\
C.V. & 2.109 & 0.927 \\
MEDIAN & 1492.000 & 20001.000
\end{tabular}

$$
\text { CR } \quad F E
$$

LA

$\begin{array}{rrr}103 & 103 & 103 \\ 413.000 & 16.700 & 7.890 \\ 3875.000 & 28417.000 & 15599.000 \\ 3462.000 & 28400.300 & 15591.110 \\ 1399.437 & 13281.304 & 2599.080 \\ 778162.190 & .388808 E+08 & .255639 E+08 \\ 882.135 & 6235.448 & 5056.078 \\ 86.919 & 614.397 & 498.190 \\ 1.022 & -0.653 & 1.688 \\ .0 .026 & -0.496 & 1.087 \\ 144142.000 & 1367974.300 & 267705.260 \\ 0.630 & 0.469 & 1.945 \\ 899.000 & 16100.000 & 68.700\end{array}$

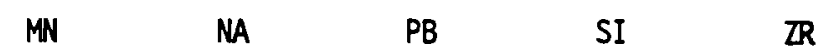

N OF CASES
MINIMUM
MAXIMUM
RANGE
MEAN
VARIANCE
STANDARD DEV
STD. ERROR
SKEWNESS(G1)
KURTOSIS(G2)
SUM
C.V.
MEDIAN

$\begin{array}{rr}103 & 103 \\ 31.000 & 33576.000 \\ 25880.000 & 125000.000 \\ 25849.000 & 91424.000 \\ 3072.019 & 84304.971 \\ 397227 \mathrm{E}+08 & .739592 \mathrm{E}+09 \\ 6302.593 & 27195.444 \\ 621.013 & 2679.647 \\ 2.350 & -0.814 \\ 4.547 & -0.629 \\ 316418.000 & 8683412.000 \\ 2.052 & 0.323 \\ 111.000 & 93685.000\end{array}$

$$
\begin{array}{rr}
103 & 103 \\
35.000 & 947.000 \\
2244.000 & 59723.000 \\
2209.000 & 58776.000 \\
599.653 & 9122.029 \\
337540.192 & .895065 \mathrm{E}+08 \\
580.982 & 9460.789 \\
57.246 & 932.199 \\
1.255 & 3.801 \\
0.637 & 15.609 \\
61764.300 & 939569.000 \\
0.969 & 1.037 \\
460.000 & 8171.000
\end{array}
$$

$\mathbb{Z R}$

N OF CASES
MINIMUM
MAXIMUM
RANGE
MEAN
VARIANCE
STANDARD DEV
STD. ERROR
SKEWNESS(G1)
KURTOSIS(G2)
SUM
C.V.
MEDIAN

CS137 SR90

100
0.011
190.000
189.989
28.780
1823.219
42.699
4.270
2.337
4.690
2877.981
1.484
14.490

$$
\begin{array}{r}
86 \\
0.830 \\
356.000 \\
355.170 \\
92.416 \\
14700.248 \\
121.245 \\
13.074 \\
0.984 \\
-0.705 \\
7947.818 \\
1.312 \\
10.080
\end{array}
$$

\begin{tabular}{|c|c|c|c|c|c|}
\hline & N03 & N02 & $F$ & $\mathrm{CL}$ & TOC \\
\hline $\begin{array}{l}\text { N OF CASES } \\
\text { MINIMUM } \\
\text { MAXIMUM } \\
\text { RANGE } \\
\text { MEAN } \\
\text { VARIANCE } \\
\text { STANDARD DEV } \\
\text { STD. ERROR } \\
\text { SKEWNESS(G1) } \\
\text { KURTOSIS(G2) } \\
\text { SUM } \\
\text { C.V. } \\
\text { MEDIAN }\end{array}$ & $\begin{array}{r}76 \\
36100.000 \\
235000.000 \\
198900.000 \\
112950.000 \\
.322513 \mathrm{E}+10 \\
56790.219 \\
6514.285 \\
0.290 \\
-1.256 \\
8584200.000 \\
0.503 \\
103450.000\end{array}$ & $\begin{array}{r}76 \\
439.000 \\
50000.000 \\
49561.000 \\
12091.250 \\
.198215 \mathrm{E}+09 \\
14078.890 \\
1614.959 \\
1.366 \\
0.874 \\
918935.000 \\
1.164 \\
9170.000\end{array}$ & $\begin{array}{r}76 \\
108.000 \\
11000.000 \\
10892.000 \\
4178.816 \\
9980675.326 \\
3159.221 \\
362.387 \\
0.362 \\
-1.181 \\
317590.000 \\
0.756 \\
3115.000\end{array}$ & $\begin{array}{r}76 \\
362.000 \\
3520.000 \\
3158.000 \\
1351.487 \\
644527.906 \\
802.825 \\
92.090 \\
1.357 \\
0.911 \\
102713.000 \\
0.594 \\
1100.000\end{array}$ & $\begin{array}{r}63 \\
298.000 \\
33200.000 \\
32902.000 \\
2416.317 \\
310176 \mathrm{E}+08 \\
5569.344 \\
701.671 \\
5.018 \\
24.326 \\
152228.000 \\
2.305 \\
1090.000\end{array}$ \\
\hline
\end{tabular}

PU23940

U

P04

829.000

825.100

96.616

24894.848

157.781

15.547

2.932

9951.490

1.633

45.000 
FRI 1/27/95 2:15:38 PM D: ISORWTIDEN_SORT.SYS

THE FOLLOWING RESULTS ARE FOR:

$$
\text { GROUPNO\$ = IV }
$$

TOTAL OBSERVATIONS: 1

DENSITY

$\begin{array}{lc}\text { N OF CASES } & 1 \\ \text { MINIMUM } & 1.640 \\ \text { MAXIMUM } & 1.640 \\ \text { RANGE } & 0.000 \\ \text { MEAN } & 1.640 \\ \text { VARIANCE } & : \\ \text { STANDARD DEV } & : \\ \text { STD. ERROR } & : \\ \text { SKEWNESS(G1) } & : \\ \text { KURTOSIS(G2) } & 1.640 \\ \text { SUM } & 0.000 \\ \text { C.V. } & 1.640 \\ \text { MEDIAN } & \end{array}$

THE FOLLOWING RESULTS ARE FOR: GROUPNO\$ $=$ VII

TOTAL OBSERVATIONS: $\quad 32$

DENSITY

$\begin{array}{lr}\text { N OF CASES } & 32 \\ \text { MINIMUM } & 0.870 \\ \text { MAXIMUM } & 1.400 \\ \text { RANGE } & 0.530 \\ \text { MEAN } & 1.171 \\ \text { VARIANCE } & 0.018 \\ \text { STANDARD DEV } & 0.133 \\ \text { STD. ERROR } & 0.024 \\ \text { SKEWNESS(G1) } & -0.474 \\ \text { KURTOSIS(G2) } & -0.552 \\ \text { SUM } & 37.470 \\ \text { C.V. } & 0.114 \\ \text { MEDIAN } & 1.200\end{array}$

THE FOLLOWING RESULTS ARE FOR: GROUPNOS $=$ XII

TOTAL OBSERVATIONS: $\quad 8$

DENSITY

$\begin{array}{lr}\text { N OF CASES } & 8 \\ \text { MINIMUM } & 1.000 \\ \text { MAXIMUM } & 1.470 \\ \text { RANGE } & 0.470 \\ \text { MEAN } & 1.286 \\ \text { VARIANCE } & 0.025 \\ \text { STANDARD DEV } & 0.159 \\ \text { STD. ERROR } & 0.056 \\ \text { SKEWNESS (G1) } & -0.490 \\ \text { KURTOSIS(G2) } & -0.739 \\ \text { SUM } & 10.290 \\ \text { C.V. } & 0.124 \\ \text { MEDIAN } & 1.290\end{array}$

THE FOLLOWING RESULTS ARE FOR: GROUPNO\$ $\$$ XV

TOTAL OBSERVATIONS: 2

DENSITY

$\begin{array}{lr}\text { N OF CASES } & 2 \\ \text { MINIMUM } & 1.190 \\ \text { MAXIMUM } & 1.280 \\ \text { RANGE } & 0.090 \\ \text { MEAN } & 1.235 \\ \text { VARIANCE } & 0.004 \\ \text { STANDARD DEV } & 0.064 \\ \text { STD. ERROR } & 0.045 \\ \text { SKEWNESS(G1) } & 0.000 \\ \text { KURTOSIS(G2) } & -2.000 \\ \text { SUM } & 2.470 \\ \text { C.V. } & 0.052 \\ \text { MEDIAN } & 1.235\end{array}$

THE FOLLOWING RESULTS ARE FOR: GROUPNO\$ $=$ XVI

TOTAL OBSERVATIONS: $\quad 36$

DENSITY

$\begin{array}{lr}\text { N OF CASES } & 36 \\ \text { MINIMUM } & 0.900 \\ \text { MAXIMUM } & 1.470 \\ \text { RANGE } & 0.570 \\ \text { MEAN } & 1.271 \\ \text { VARIANCE } & 0.009 \\ \text { STANDARD DEV } & 0.094 \\ \text { STD. ERROR } & 0.016 \\ \text { SKEWNESS(G1) } & -2.149 \\ \text { KURTOSIS(G2) } & 6.643 \\ \text { SUM } & 45.740 \\ \text { C.V. } & 0.074 \\ \text { MEDIAN } & 1.300\end{array}$

THE FOLLOWING RESULTS ARE FOR: ALL GROUPS

TOTAL OBSERVATIONS: $\quad 79$

DENSITY

$\begin{array}{lr}\text { N OF CASES } & 79 \\ \text { MINIMUM } & 0.870 \\ \text { MAXIMUM } & 1.640 \\ \text { RANGE } & 0.770 \\ \text { MEAN } & 1.236 \\ \text { VARIANCE } & 0.018 \\ \text { STANDARD DEV } & 0.134 \\ \text { STD. ERROR } & 0.015 \\ \text { SKEWNESS(G1) } & .0 .513 \\ \text { KURTOSIS(G2) } & 1.073 \\ \text { SUM } & 97.610 \\ \text { C.V. } & 0.109 \\ \text { MEDIAN } & 1.280\end{array}$


FRI 1/27/95 2:10:58 PM D: ISORWTISORWT_S.SYS

THE FOLLOWING RESULTS ARE FOR: GROUPNOS IV

TOTAL OBSERVATIONS: 12

$\mathrm{PH}$

$\begin{array}{lr}\text { N OF CASES } & 10 \\ \text { MINIMUM } & 10.170 \\ \text { MAXIMUM } & 13.380 \\ \text { RANGE } & 3.210 \\ \text { MEAN } & 12.803 \\ \text { VARIANCE } & 0.903 \\ \text { STANDARD DEV } & 0.950 \\ \text { STD. ERROR } & 0.300 \\ \text { SKEWNESS(G1) } & -2.420 \\ \text { KURTOSIS(G2) } & 4.322 \\ \text { SUM } & 128.030 \\ \text { C.V. } & 0.074 \\ \text { MEDIAN } & 13.085\end{array}$

THE FOLLOWING RESULTS ARE FOR: GROUPNOS $=$ VII

TOTAL OBSERVATIONS: 22

$\mathrm{PH}$

$\begin{array}{ll}\text { N OF CASES } & \\ \text { MINIMUM } & : \\ \text { MAXIMUM } & : \\ \text { RANGE } & : \\ \text { MEAN } & : \\ \text { VARIANCE } & : \\ \text { STANDARD DEV } & : \\ \text { STD. ERROR } & : \\ \text { SKEWNESS(G1) } & : \\ \text { KURTOSIS(G2) } & : \\ \text { SUM } & \text { C.V. } \\ \text { MEDIAN } & :\end{array}$

THE FOLLOWING RESULTS ARE FOR: GROUPNOS $=$ XII

TOTAL OBSERVATIONS: $\quad 18$

$\mathrm{PH}$

$\begin{array}{lr}\text { N OF CASES } & 14 \\ \text { MINIMUM } & 9.580 \\ \text { MAXIMUM } & 11.330 \\ \text { RANGE } & 1.750 \\ \text { MEAN } & 10.631 \\ \text { VARIANCE } & 0.444 \\ \text { STANDARD DEV } & 0.666 \\ \text { STD. ERRR } & 0.178 \\ \text { SKEWNESS(G1) } & -0.760 \\ \text { KURTOSIS(G2) } & -1.135 \\ \text { SUM } & 148.840 \\ \text { C.V. } & 0.063 \\ \text { MEDIAN } & 10.880\end{array}$

THE FOLLOWING RESULTS ARE FOR: GROUPHOS $=\mathrm{XV}$

TOTAL OBSERVATIONS: $\quad \theta$

$\mathrm{PH}$

$\begin{array}{lc}\text { N OF CASES } & \\ \text { MINIMUM } & 11.650 \\ \text { MAXIMUM } & 11.650 \\ \text { RANGE } & 0.000 \\ \text { MEAN } & 11.650 \\ \text { VARIANCE } & : \\ \text { STANDARD DEV } & : \\ \text { STD. ERROR } & : \\ \text { SKEWNESS(G1) } & : \\ \text { KURTOSIS(G) } & 11.650 \\ \text { SUM } & 0.000 \\ \text { C.V. } & 11.650\end{array}$

THE FOLLOWING RESULTS ARE FOR: GROUPHOS $=$ XVI

TOTAL OBSERVATIONS: 48

$\mathrm{PH}$

$\begin{array}{lr}\text { N OF CASES } & 13 \\ \text { MINIMUM } & 7.570 \\ \text { MAXIMUM } & 8.990 \\ \text { RANGE } & 1.420 \\ \text { MEAN } & 8.221 \\ \text { VARIANCE - } & 0.197 \\ \text { STANDARD DEV } & 0.444 \\ \text { STD. ERROR } & 0.123 \\ \text { SKEWNESS(G1) } & 0.574 \\ \text { KURTOSIS(G) } & -0.778 \\ \text { SUM } & 106.870 \\ \text { C.V. } & 0.054 \\ \text { MEDIAN } & 8.120\end{array}$

THE FOLLOWING RESULTS ARE FOR: ALL GROUPS

TOTAL OBSERVATIONS: 108

PH

$\begin{array}{lr}\text { N OF CASES } & 38 \\ \text { MINIMUM } & 7.570 \\ \text { MAXIMUM } & 13.380 \\ \text { RANGE } & 5.810 \\ \text { MEAN } & 10.405 \\ \text { VARIANCE } & 3.731 \\ \text { STANDARD DEV } & 1.932 \\ \text { STD. ERROR } & 0.313 \\ \text { SKEWNESS(G1) } & 0.119 \\ \text { KURTOSIS(G2) } & -1.296 \\ \text { SUM } & 395.390 \\ \text { C.V. } & 0.186 \\ \text { MEDIAN } & 10.780\end{array}$




\section{Distribution}

No. of

Copies

\section{OFFSITE}

12 DOE/Office of Scientific and Technical Information

D. Wynne

EM-361, Trevion II

U.S. Department of Energy

12800 Middlebrook Road

Germantown, MD 20874

S. F. Agnew

Chemical Science \& Technology

Division

Los Alamos National Laboratory

Los Alamos, NM 87545

E. C. Beahm

Martin Marietta Energy Systems, Inc.

P.O. Box 2008

Oak Ridge, TN 37831-6223

B. Z. Egan

Martin Marietta Energy Systems, Inc.

P.O. Box 2008

Oak Ridge, TN 37831-6223

R. King

Washington Department of Ecology

P.O. Box 47600

Olympia, WA $98594-7600$

\section{ONSITE}

3 DOE Richland Operations

S. T. Burnum, R3-74

R. A. Gilbert, R3-74

P. E. Lamont, R3-74
No. of

Copies

29 Westinghouse Hanford Company

J. N. Appel, L6-29

H. Babad, S7-30

S. A. Barker, L6-29

W. B. Barton, L4-75

A. L. Boldt, H5-49

K. D. Boomer, H5-49

T. M. Brown, R2-12

S. J. Eberline, R2-12

K. A. Gasper, L6-29

L. Jensen, T6-07

R. A. Kirkbride, S4-58

M. J. Kupfer, H5-49

D. J. McCain, R2-12

G. T. McLean, S4-58

R. M. Orme, S4-58

R. S. Popielarczyk, R1-30

I. E. Reep, L6-29

L. W. Shelton, Jr., H5-49

B. C. Simpson, R2-12 (10)

D. J. Washenfelder, L4-75

50 Pacific Northwest Laboratory

G. S. Anderson, K7-94 (5)

E. G. Baker, P8-38

D. L. Blanchard, Jr.,P7-25

B. C. Bunker, K2-45

N. G. Colton, K3-75 (5)

J. M. Creer, K9-80

A. R. Felmy, K9-77

S. R. Gano, P8-38

S. T. Hartley, K5-12

P. G. Heasler, K5-12

J. G. Hill, K7-94 (5) 
No. of

Copies

L. K. Holton, P7-43 (5)

B. M. Johnson, K1-78

W. L. Kuhn, K2-21

D. E. Kurath, P7-43

J. P. LaFemina, K2-25 (5)

J. Liu, K2-44

G. J. Lumetta, P7-25
No. of

Copies
B. M. Rapko, P7-25
K. M. Remund, K5-12
B. A. Reynolds, P7-19
L. J. Sealock, Jr., K2-10
J. T. Slankas, K9-81
J. L. Swanson, P7-25
Publishing Coordination
Technical Report Files (5) 